Andrews University

Digital Commons @ Andrews University

1991

\title{
Humanist Reconceptualization Of The Dogmatic Marxist Concept Of Religion By Esad Ćimić
}

Radisa Antic

Andrews University

Follow this and additional works at: https://digitalcommons.andrews.edu/dissertations

Part of the Religious Thought, Theology and Philosophy of Religion Commons

\section{Recommended Citation}

Antic, Radisa, "Humanist Reconceptualization Of The Dogmatic Marxist Concept Of Religion By Esad Ćimić" (1991). Dissertations. 1640.

https://digitalcommons.andrews.edu/dissertations/1640

https://dx.doi.org/10.32597/dissertations/1640

This Dissertation is brought to you for free and open access by the Graduate Research at Digital Commons @ Andrews University. It has been accepted for inclusion in Dissertations by an authorized administrator of Digital Commons@ Andrews University. For more information, please contact repository@andrews.edu. 


\section{INFORMATION TO USERS}

This manuscript has been reproduced from the microfilm master. UMI films the text directly from the original or copy submitted. Thus, some thesis and dissertation copies are in typewriter face, while others may be from any type of computer printer.

The quality of this reproduction is dependent upon the quality of the copy submitted. Broken or indistinct print, colored or poor quality illustrations and photographs, print bleedthrough, substandard margins, and improper alignment can adversely affect reproduction.

In the unlikely event that the author did not send UMI a complete manuscript and there are missing pages, these will be noted. Also, if unauthorized copyright material had to be removed, a note will indicate the deletion.

Oversize materials (e.g., maps, drawings, charts) are reproduced by sectioning the original, beginning at the upper left-hand corner and continuing from left to right in equal sections with small overlaps. Each original is also photographed in one exposure and is included in reduced form at the back of the book.

Photographs included in the original manuscript have been reproduced xerographically in this copy. Higher quality $6^{\prime \prime} \times 9^{\prime \prime}$ black and white photographic prints are available for any photographs or illustrations appearing in this copy for an additional charge. Contact UMI directly to order.

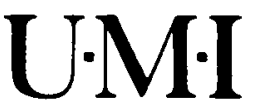

University Microlims International

A Bell \& Howell Information Company

300 North Zeeb Road. Ann Arbor. MI 48106-1346 USA

$313 / 761-4700 \quad 800 / 521-0600$ 
Order Number 9129720

Humanist reconceptualization of the dogmatic Marxist concept of religion by Esad Ćmic

Antik, Radiša, Ph.D.

Andrews University, 1991

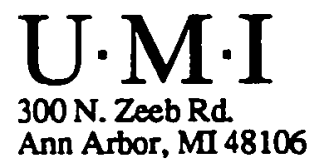

Reproduced with permission of the copyright owner. Further reproduction prohibited without permission. 


\title{
Andrews University \\ Seventh-day Adventist Theological Seminary
}

\author{
HUMANIST RECONCEPTUALIZATION OF THE DOGMATIC \\ MARXIST CONCEPT OF RELIGION \\ BY ESAD ĆIMIĆ
}

\author{
A Dissertation \\ Presented in Partial Fulfillment \\ of the Requirements of the Degree \\ Doctor of Philosophy
}

by

Radiša Antić

May 1991

Reproduced with permission of the copyright owner. Further reproduction prohibited without permission. 


\section{ABSTRACT \\ HUMANIST RECONCEPTUALIZATION OF THE DOGMATIC \\ MARXIST CONCEPT OF RELIGION \\ BY ESAD ĆIMIĆ}

by

Radiša Antić

Adviser: Miroslav Kiš

Reproduced with permission of the copyright owner. Further reproduction prohibited without permission. 


\title{
ABSTRACT OF GRADUATE STUDENT RESEARCH \\ Dissertation
}

\author{
Andrews University \\ Seventh-day Adventist Theological Seminary
}

Title: HUMANIST RECONCEPTUALIZATION OF THE DOGMATIC MARXIST
CONCEPT OF RELIGION BY ESAD CIMIĆ Name of the researcher: Radiša Antic

Name and degree of faculty adviser: Miroslav Kiš, Ph.D. Date completed: May 1991.

This study analyzes and evaluates the humanist reconceptualization of the dogmatic-Marxist concept of religion by the Yugoslav philosopher Esad Ċimić. The questions we address are: How did cimie reshape the dogmatic Marxist criticism of religion? and what is the significance of this reshaping for both dogmatic Marxism and Christianity?

We begin with the broad outiines of the concepts of metaphysics and epistemology of both dogmatic and humanist Marxism because they provide the basic presuppositions for the understanding of the phenomenon of religion in Marxism. Then, we address those elements of ćimic's life and philosophy which define him as a man and as a philosopher of 
religion. These matters are of essential importance for the proper understanding of Ćimie's concept of religion. We analyze ćimić's reconceptualization of the dogmatic Marxist concept of religion. Cimic rejects the basic dogmatic Marxist concepts of religion as they existed in socialist societies contending that religious alienation is caused by the multiplicity of sources. In his view, religion is not a simple but complex phenomenon which possesses several dimensions.

Ćimić argues that religion per se is an expression of human beings' natural desire for self-transcendence. Religion is also a socio-historical fact which is caused by the unjust socio-economical conditions. In addition, religion is to be seen as an anthropo-psychological structure which demonstrates that every person has a unique mental composition by which he expresses his religiosity. Ćimic contends that the solution for the religious alienation is to be found in the "socially transforming atheism."

Cimic's contribution to the concept of religion is evaluated from three perspectives: that of dogmatic Marxism, that of inner consistency of his philosophical system, and that of Christian-theism. We conclude that cimic is to be viewed as a revisionist who has reinterpreted and rejected most aspects of dogmatic Marxism although he has retained some of its features. He can be considered a post-Marxist 
in that his philosophy, in some respects, goes beyond the Marxist understanding of religion. In addition, ćimic has made a significant contribution to a creation of new conditions of religious freedom in Yugoslavia as well as in other countries. Thus, he is to be viewed as a forerunner of the present changes in Eastern Europe. 


\section{HUMANIST RECONCEPTUALIZATION OF THE DOGMATIC MARXIST CONCEPT OF RELIGION \\ BY ESAD CंIMIC}

A dissertation

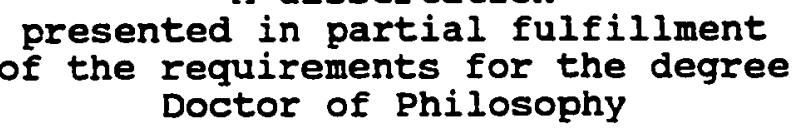

Doctor of Philosophy

by

Radiśa Antić

APPROVAL BY THE COMMITTEE:
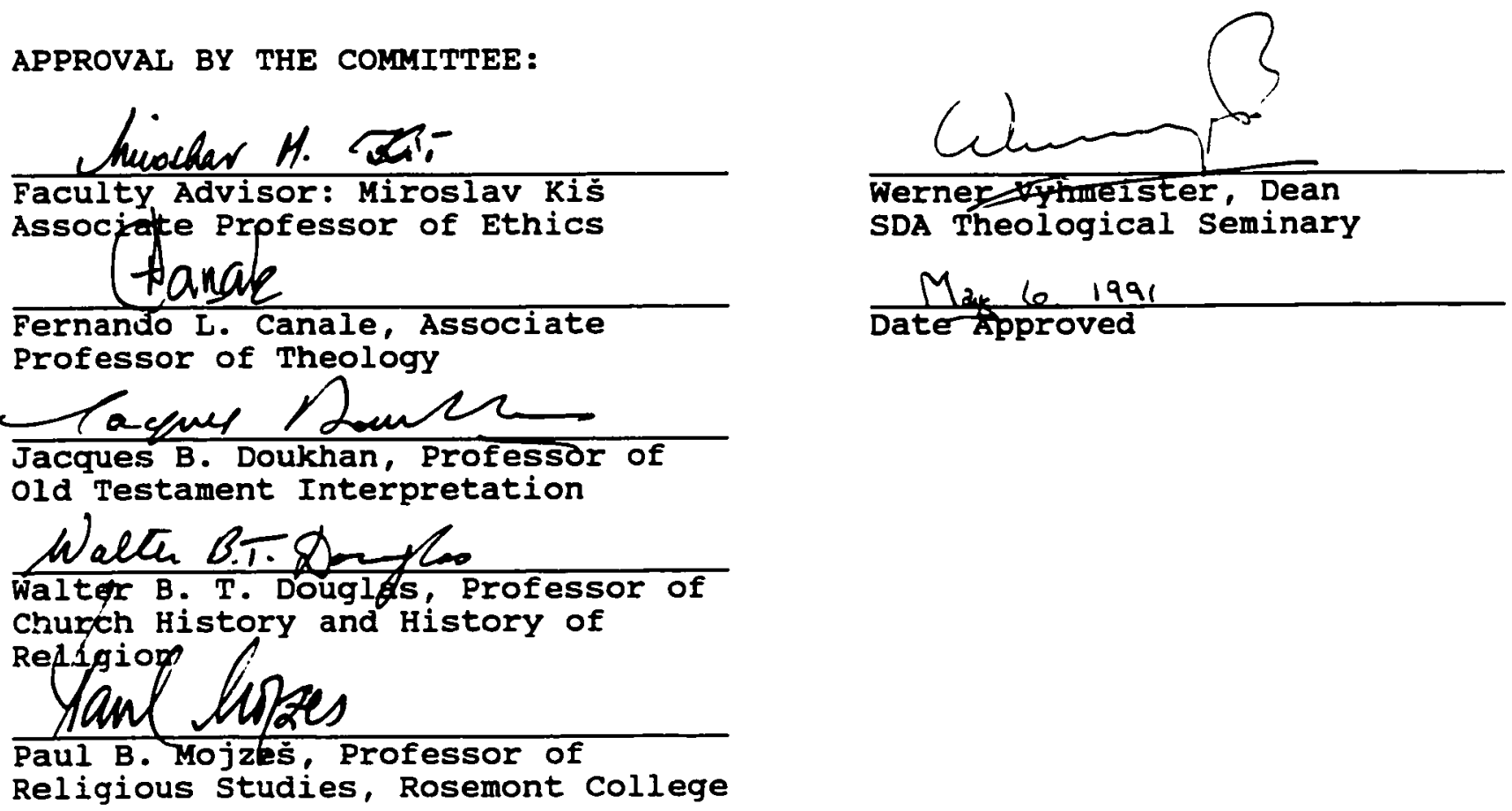
To svetlana, my beloved wife, and to our son Filip

i i

Reproduced with permission of the copyright owner. Further reproduction prohibited without permission. 
TABLE OF CONTENTS

\section{Chapter}

I. INTRODUCTION . . . . . . . . . . . . . . . 1

Historical-Philosophical Background . . . . . 1 Dogmatic Marxism . . . . . . . . . . . 2

Humanist Marxism .. . . . . . . . . . 4 4

The Case of Esad Ćimic . . . . . . . . . . . 11

Purpose of the study . . . . . . . . . . . . 12

Importance of the Issue . . . . . . . . . . . 12

Review of Literature . . . . . . . . . . . . 14

Research Methodology . . . . . . . . . . 19

Limitations .................. 20

Outline of the study . . . . . . . . . . 21

II. HISTORICAL BACKGROUND TO THE PROBLEM . . . . . . 24

Dogmatic versus Humanist Marxism . . . . . 25

Metaphysics . . . . . . . . . . . . 31

Dogmatic view . . . . . . . . . . . . . 31

Humanist view . . . . . . . . . . . 34

Summary . . . . . . . . . . . . . . . 36

Epistemology . . . . . . . . . . . . . 37

Dogmatic view . . . . . . . . . . 37

Humanist View . . . . . . . . . . . . . 39

Summary .. . . . . . . . . . . . . . . . 40

Religion ................... . . 41

Dogmatic view .. . . . . . . . . . . 41

humanist view . . . . . . . . . . . . 47

Summary . . . . . . . . . . . . . . . . . 54

Ambiguity of Marx's Legacy .... . . . . 56

An Example of the Ambiguity of

Marx's Philosophy in General . . . 56

Marx's Concept of Religion . . . . . . 62

Yugoslav Humanist Marxist Thought . . . . . . 65

Historico-Political Background . . . . . . 67

Man as Praxis ................ 71

Man and Alienation ............. . . 74

Man and Self-Management . . . . . . . . . 77

The Concept of Religion in the Yugoslav

Humanist Marxist Thought .... . . 80

Summary . . . . . . . . . . . . . . 85

Summary and conclusion... . . . . . . 86

\section{iii}


III. ESAD ĆIMIĆ, THE MAN AND HIS THOUGHT . . . . . . . 91

Ćimic's Early Life, Education and Career . . . 91

Ćimić's Professional Pilgrimage . . . . . . . 94

The Starting Point of Ćimic's Philosophy . . . 103

Shift in Cimie's Philosophy . . . . . . . . . 108

ćimić's Theoretical Basis . . . . . . . . . . 114

Metaphysics . . . . . . . . . . . . 115

Epistemology . . . . . . . . . . . . . . 117

Cimic's View of the origins and

Development of Marx's Thought on

the Question of Religion . . . . . . 119

Cimic's View of the "Early" and

"Later" Marx . . . . . . . . . . . . 126

Cimic's View of the Relation of

Science and Religion .. . . . . . . . 131

Ćimié's Methodological Presuppositions . . 134

summary . . . . . . . . . . . . . . . 135

IV. ĆIMIĆ'S RECONCEPTUALIZATION OF THE DOGMATIC

MARXIST CONCEPT OF RELIGION . . . . . . . . . . . 140

Basic Concepts of Religious Phenomenon

in the context of socialist societies

as Viewed by ćimic . . . . . . . . . . . 141

Eniightenment-Rationalistic concept . . . . 141

Spontaneous-Economic Concept . . . . . . 145

Administrative Concept . . . . . . . . . 148

Humanist-Marxist Concept . . . . . . . . 151

Summary . . . . . . . . . . . . . . . . . . 152

Religion as Alienation and Its Sources . . . . 154

Religion as Alienation . . . . . . . . . 155

Sources of Religion as Alienation . . . . . 160

The Socio-Economic Source of Religion . 161

The Socio-Psychological Sources

of Religion . . . . . . . . . . . 163

Anxiety... . . . . . . . . . . 164

Mortality . . . . . . . . . . 165

Vulnerability . . . . . . . . . . . 167

The Socio-Cognitive Source of Religion . 168

The Socio-Moral Source of Religion . . . 172

Summary .................... . . 174

Different Dimensions of Religion According

to cimic .. . . . . . . . . . . . . . . 177

Supernatural Dimension . . . . . . . . 178

Holy Dimension . . . . . . . . . . . . 181

Ritual Dimension . . . . . . . . . . . 182

Moral Dimension . . . . . . . . . . . 185

Summary . . . . . . . . . . . . . . . . 187

Summary and Conclusion . . . . . . . . . 188 
V. ĆIMIĆ'S CONCEPT OF RELIGION . . . . . . . . . . . 191

Cimic's view of the Limited scope of Marx's

Critique of Religion . . . . . . . . . . 192

Forms of Religious Phenomenon . . . . . . . 199

Religion Per Se . . . . . . . . . . . . 199

Religion as Socio-Historical Fact. . . . . 204

Religion as Anthropo-Psychological

Structure ............ . . . 208

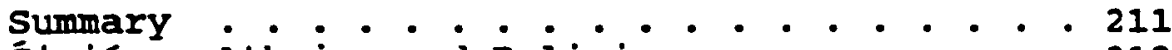

Cimit on Atheism and Religion . . . . . . . 212

Atheism and Its Relationship

to Religion . . . . . . . . . . . . 213

Ćimic's Main Philosophical Ideas . . . . . 224

God . . . . . . . . . . . . . . . . . . 224

Man . . . . . . . . . . . . . . . 226

Ethics . . . . . . . . . . . . . . 229

History . . . . . . . . . . . . . . 231

Freedom . . . . . . . . . . . . . 233

Self-Management . . . . . . . . . . . . 236

Summary . . . . . . . . . . . . . . . 239

VI. EVALUATION OF ĆIMIĆ'S CONTRIBUTION TO THE

CONCEPT OF RELIGION . . . . . . . . . . . . . 243

Evaluation of ćimic's Concept of Religion

from the Marxist-Dogmatic Perspective . . . 245

Similarities . . . . . . . . . . . . . . . 246

The Prime Importance of the Socio-

Economic Conditions . . . . . . . . 247

The Possibility of the "Light of

Consciousness" in Religious

People . . . . . . . . . . . 250

Atheism as a "Demystified

Consciousness" . . . . . . . . . . 253

Differences . . . . . . . . . . . . . 257

New Way of Thinking about Religion . . . 257

New Method of Interpreting Marx . . . . 259

Rejection of Dogmatic-Marxist Concepts

of Religion Used in Socialist

Countries ... . . . . . . . . . 260

Religion Is Not a simple, but a Multi-

dimensional and Relatively Autonomous

Phenomenon ..... . . . . . . 263

Religion Is Not opposed to science . . . 267

Religiosity Will Probably Not Disappear

in Any Future Form of Society . . . . 271

Evaluation of Internal Inconsistencies in the

Theoretical Base of ćimic's Philosophy . . 272

Evaluation of cimic's Concept of Religion

from the Christian-Theistic Perspective . . 281

$\mathbf{v}$

Reproduced with permission of the copyright owner. Further reproduction prohibited without permission. 


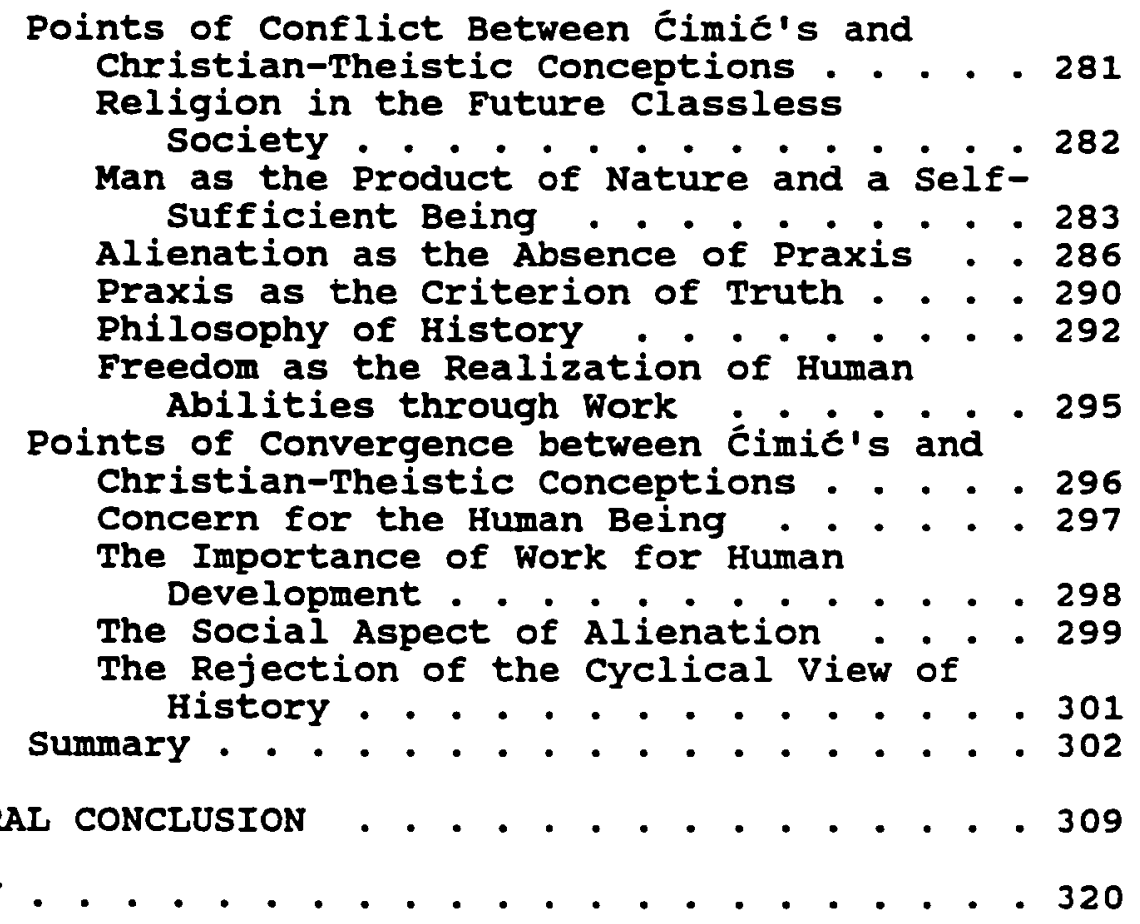

vi 
ACKNOWLEDGMENTS

It is impossible to mention by name each person who has been a contributor to this doctoral adventure. Because of that I would like to mention those who were more directly involved in the process of bringing forth this study. Particular thanks go to the members of my advisory committee: to Doctor Jacques Doukhan, who stimulated my interest and manifested a sustained enthusiasm for the topic; to Doctor Fernando Canale, who provided philosophical sensitivity and timely encouragement; and to Doctor Miroslav Kiš, who guided the entire project, constantly upholding a higher standard of excellence.

I am also grateful to my wife, svetlana, and to my son Filip for their unfailing support and daily encouragement that sustained me along the way. Most of all I am grateful to God who is the only source of every talent and to whom all glory belongs. 
CHAPTER I

INTRODUCTION

Historical-Philosophical Backaround

It is methodologically incorrect to assume that

Marxism, from the theoretical and empirical point of view, is an homogenous system. One cannot speak of one Marxism either as a political theory which longs for a change of human relations or as a worldview. Consequently, one must speak of Marxisms, or about a plurality of Marxist traditions which are related only by a common name and an appeal to the work of Marx. ${ }^{1}$ In this study we consider two

\footnotetext{
${ }^{1}$ Roter goes so far as to say that there are more common points (empirical and theoretical) between "left wing" Christians and humanist Marxists than between humanist Marxists and dogmatic Marxists (zdenko Roter, Marxism and the Religious Question, paper presented at a conference of autinors of a multi-volume series on "Religious Education for Dialogue and Peace," Minneapolis, 4-9 April 1989). Gorman writes that contemporary Marxism encompasses at least four distinct philosophical perspectives which include materialism, idealism, empiricism, and experimentalism (Robert A. Gorman, "Introduction: The Mosaic of Marxism," Biographical Dictionary of Neo-Marxism [1985], 5). This study analyzes dogmatic and humanist Marxism since they represent the background for the understanding of cimic's philosophy (for further information, see Esad cimic, Socijalisticko Društvo i Religija [Sarajevo: Svjetlost, 1966 ], 13-23; Paul Mojzes, Christian-Marxist Dialogue in Eastern Europe [Minneapolis: Augsburg Publishing House, 1981], 221-229; and idem, Mojzes Addendum, paper presented at a conference of authors of a multi-volume series on
} 
extreme traditions, namely, the dogmatic and humanist

Marxist schools of thought.

\section{Dogmatic Marxism}

The first tradition is the Marxism that was

developed in the U.S.S.R. and other Eastern European

countries where it had enjoyed and held a monopolist social

and political position. I It is usually called "dogmatic"

Marxism or the Bolshevik-Leninist-stalinist interpretation

of Marxism. ${ }^{2}$

"Religious Education for Dialogue and Peace," Minneapolis, 4-9 April 1989).

${ }^{1}$ See Roter, Marxism and the Religious ouestion, 2 .

${ }^{2}$ Gruenwald calls dogmatic Marxism "official" Marxism in opposition to "unofficial" Marxism. He writes: "It is necessary to differentiate from the outset between two kinds of reinterpretations of Marxism, that is, the official and the unofficial, which are by no means separated by watertight compartments, but, on the contrary, interact constantly. However, these two sets of interpretations are not identical" (Oscar Gruenwald, "Humanism and Marxism: The Yugoslav Perspective" [Ph.D. diss., Claremont Graduate School, 1971], 25); Roter reacts to the fact that the Western world overlooked the existence of two different Marxisms in the Eastern European socialist countries: "During the entire period of the existence of Eastern European socialist states it was not only typical that there was a repressive Jacobin-Bolshevik dictatorship (also in regard to religion), but that there was a protest, a resistance to such a dictatorship. What is essential for our subject matter is the permanent existence and renewal of a serious protest against the ruling, official understanding and practice of Marxism as well as to its relationship toward religion within the communist movement, within the Marxist inspired intellectual groups, and even within the ruling politocracies, i.e. oligarchic groups" (Roter, Marxism and the Religious Question, 3). 
In the dogmatic Marxist view, the universe is run by the immutable laws of matter ${ }^{1}$ which must be first understood and then applied. The laws of society have the same nature of immutability as the laws of matter and are complementary to them. ${ }^{2}$ only those who clearly understand the true nature of scientific laws (laws of matter and laws of social development), and who decide to abide by their predetermined character are free and fit to guide society in the direction in which it is heading anyway. ${ }^{3}$

One of the basic postulates of "dogmatic" Marxism is that there is complete incompatibility between Marxism-

\footnotetext{
${ }^{1}$ For the Marxist understanding of the concept of "matter," see below, 27, 31-33.

${ }^{2}$ See Vladimir I. Lenin, Absolute and Relative Truth, or the Eclecticism of Engels as Discovered by Bogdanov," in V. I. Lenin: Selected Works, ed. Marx-Engels-Lenin Institute (New York: International Publishers, 1942), 199-200.

${ }^{3}$ since the Marxist social scientists (of all social scientists) are the only ones who have a full grasp of these laws, they are fit to be the vanguard leading the proletariat which is the only element in socieiy capable of being the powerful historical agent of change (see iden, Political Report of the Central Committee to the 11th Congress of the Russian Communist Party," in V. I. Lenin: Selected Works, ed. Marx-Engels-Lenin Institute [New York: International Publishers, 1943], 328-338; The Three Sources and Three Component Parts of Marxism," in V. I. Lenin: Selected Works, ed. Marx-Engels-Lenin Institute [New York: International Publishers, 1942], 3; see also Mala Politicka Enciklopedita [Belgrade: Savremena Administracija, 1966], 1179 ; Mojzes, Mojzes Addendum, 1; Predrag Vranicki, Historija Marksizma [Zagreb: Naprijed, 1961], 596; Rudi Supek, Sociologija i Socijalizam [Zagreb: Znanje, 1966], 2629).
} 
Leninism and religion. 1 under the conditions of class society religion appears as a mystification of social and natural relations and is used by the ruling class to hold exploited classes in passive suojection. ${ }^{2}$

Humanist Marxism

Stalin's death in 1953 was followed by the period of de-stalinization mainly initiated by Nikita Khrushchev's denunciation of Stalin's rule during the Twentieth congress of the Communist Party of the Soviet Union (1956). Many Marxist thinkers began to believe that Marx's work

1"Marxism is materialism. As such it is as relentlessly hostile to religion as was the materialism of the Encyclopedists of the eighteenth century or the materialism of Feuerbach. - . We must combat religion-that is the rudiment of all materialism, and consequently of Marxism" (Vladimir I. Lenin, Attitude of the Workers Party toward Religion, in $V$. I. Lenin: Selected Works, ed. MarxEngels-Lenin Institute [New York: International Publishers, 1942], 666).

${ }^{2}$ Idem, Socialism and Religion, in V. I. Lenin: Selected Works, ed. Marx-Engels-Lenin Institute Socialism and Religion (New York: International Publishers, 1943), 658. Gustav Wetter made summaries of the papers that were presented at the Fifteenth World Philosophical Congress in Varna, Bulgaria. For example, 0 . Klohr attempted to prove statistically and theoreticaliy that religion is dying out. V. D. Timofeev stated that religion still did not lose its character as "the opium of the people." For I. Slanikov, religion is the compensation for the incomplete fulfillment of the people. It helps them to be more stabilized but at the same time makes it impossible for them to be active in society, to work for change. A. F. Okulov said that religion will disappear with the changes of society (Gustav Wetter, S.J., "Die Marxistische Religionsphilosophie auf dem XI. Weltkongress der Philosophie," Gregorianum 55 [1974]: 151-160): All this shows that the dogmatic Marxist concept of religion was until recently alive among those who accept the so-called Marxist-Leninist interpretation of Marx. 
(including his analysis of religion and Christianity) was limited, incomplete, and fragmentary. His analysis of reality was considered to be mainly the result of pragmatic considerations and historical influences. Therefore, from this perspective, not all insights of Marx himself and of the later Marxists are equally valid or valid at all. There is a need to up-date or revise some of the ideas taught by the classics of Marxism. These Marxists labeled themselves as "humanist," "creative," or "authentic," but their dognatic opponents labeled them as "revisionists." I

Humanist Marxists maintain that the dogmatic Marxist understanding of religious faith as absurd and atheism as self-evident is wrong and proposed that at times it may be more absurd not to believe in God than to believe. ${ }^{2}$ Both Christianity and communism, in their view, share the value of love for human beings and this, and other values of Christianity, need to be analyzed by Marxists. ${ }^{3}$

Among Communist states in Eastern Europe, 4 new,

${ }^{1}$ See Mojzes, Mojzes Addendum, 2; Roter, Marxism and the Religious Question, 8; and Oscar Gruenwald, "Praxis," Biographical Dictionary of Neo-Marxism (1985), 349-351.

2 vitezslav Gardavsky, God Is Not Quite Dead (Baltimore: Penguin Books, 1973), 15.

${ }^{3}$ Ibid.

${ }^{4}$ This study is limited to the criticism and evaluation of the dogmatic Marxism by humanist Marxist in Eastern Europe because Eastern Europe represents the most natural context and background for the understanding of ćimić's work. However, it is necessary to mention also Marxist philosophers such as Roger Garaudy, Ernst Bloch, 
unofficial reinterpretations of Marxism have been advanced most consistently in Poland, 1 Czechoslovakia, ${ }^{2}$ Hungary, 3 and Yugoslavia." Since this study deals with Esad Ćimic, who works and lives in Yugoslavia, and his reconceptualization of the dogmatic Marxist concept of

Iucion Lombardo-Radice, and Antonio Gramaci whose contribution to the better understanding of religion from the Marxist perspective and to Christian-Marxist dialogue cannot be overestimated (Mojzes, Christian-Marxist Dialogue Eastern Europe, 31; see also below, 20-21).

${ }^{1}$ In Poland the foremost proponents of Marxist humanism were Adam Schaff, Leszek Kolakowski, Stanislow Brzozowski, Marek Fritzhand, Bronislav Baczko, and Josef Edward Abramowski (for more information, see David Myers, "Schaff, Adam," Biographical Dictionary of Neo-Marxism [1985], 377-378; Adam Schaff, "Marxism and the Philosophy of Man," in Socialist Humanism: An International Symposium, ed. Erich Fromm [Garden City: Doubleday and Co., 1966], 141-146; Leszek Kolakowski, Toward a Marxist Humanism: Essays on the Left Today [New York: Grove Press, 1968], 9-37).

2The philosophers, Milan Machovec, Vitezslav Gardavsky, Milan Prucha, Robert Kalivoda, Ivan Svitak, and Jaroslav Krejci are among those Marxists in Czechoslovakia who have propounded Marxist humanism and who were attempting to rethink Marxism with special reference to their encounter with Christianity (for further information, see vladimir V. Kusin, "Prague Spring," Biographical Dictionary of NeoMarxism [1985], 347; Ivan Svitak, "The Source of Socialist Humanism," in Social Humanism: An International symposium, ed. Erich Fromm [Garden City: Doubleday and Co., 1966], 21; Milan Machovec, A Marxist Looks at Jesus [Philadelphia: Fortress Press, 1976], 192-194; Milan Prucha, "Marxism as a Philosophy of Human Existence," in The Christian-Marxist Dialogue: An International symposium, ed. Paul Oestreicher [London: The Macmillan Company, 1969], 250).

${ }^{3}$ In Hungary philosopher Jozsef Lukacs was the most open of the Marxist scholars (see Jozsef Lukacs, "Cooperation and Dialogue," in Varieties of ChristianMarxist Dialogue, ed. Paul Mojzes [Philadelphia: Ecumenical Press, 1978], 100-108).

${ }^{4}$ See Gruenwald, "Humanism and Marxism: The Yugoslav Perspective," 26-27. 
religion, we pay particular attention to the Yugoslav humanist Marxist thought.

The creative humanist reinterpretation of Marxist philosophy in Yugoslavia is very little known in the West. Howard L. Parsons writes that contemporary philosophy and sociology in Yugoslavia represent a revolutionary reinterpretation of Marxist doctrine as well as a genuine renaissance of Marxist thought. ${ }^{1}$ Arnold Künzli states that Yugoslavia remains an intellectual continent yet to be discovered. 2

In the Yugoslav humanist Marxism, one can distinguish two major schools of thought. The first is known as the "praxis school," and most of the philosophers and sociologists in this group are centered at the University of Zagreb in Croatia. They initiated the radical Marxist journal "Praxis" and the international summer school on the island of Korčula. ${ }^{3}$ This group was basically interested in

\footnotetext{
${ }^{1}$ Howard L. Parsons, humanist Philosophy in Contemporary Poland and Yugoslavia (New York: American Institute for Marxist Studies, 1966), 8. (1968):

2Arnold Künzli, "Marxists on the Beach," Dialoque 1

${ }^{3}$ The humanist philosophers and main contributors to the journal "Praxis" from the Zagreb University were: Branko Bošnjak, Danko Grlic, Milan Kangrga, Rudi Supek, Ivan Kuvacic, Gajo Petrovic, and Predrag Vranicki. Although the Bled Symposium (1960) rejected the Engels-Lenin theory of reflection and dogmatic notion of dialectical materialism as contradictory to creative Marxism, it was the Yugoslav (1964-1974) and international (1965-1974) journal Praxis and the KorCula summer School (1963-1974) that mainly contributed to the development of the humanist
} 
the reinterpretation of Marx's teachings in the light of the early Marx's writings, that is, Economic and Philosophical Manuscripts of $1844 . .^{1}$ The attention of the second group was basically drawn to the problems of philosophy of science in an attempt to reconcile the findings of the twentieth century science with the historical and dialectical materialism of Marxism. ${ }^{2}$ The philosophers and sociologists of this group were, for the most part, at the University of Belgrade in Serbia. ${ }^{3}$

Both schools share the same concern, that is, how to integrate Marx's anthropological orientation with his

reconceptualisation of dogmatic Marxism. In 1968, president Tito accused praxis philosophers of corrupting youth and encouraging student demonstrations. In 1971, after the Croatian national insurrection, liberal intellectuals found themselves increasingly isolated. In 1975 the two leading journals for humanist Marxist thought, Filozofija and praxis, were forced to close and Korcula summer school was banned (see Gruenwald, "Praxis," 349).

${ }^{1}$ see idem, "Humanism and Marxism: The Yugoslav Perspective," 81-82.

2 Ibid.

${ }^{3}$ The Marxist humanist Philosophers and sociologists from the Belgrade University are: Zagorka Pesic-Golubovic, Trivo Indjic [he later recanted and left the "Belgrade eight"], Mihallo Markovic, Dragoljub Micunovic, Nebojiša Popov, Svetozar Stojanovic, Ljubomir Tadic, and Miladin zivotic. In 1975 these professors were suspended from teaching and suspended from the University of Belgrade by the end of 1980. However, in 1981, following the protest of the international academic community, the "Belgrade Seven" were reinstated in a new Center for Philosophy and social Theory at Belgrade University. 
historical and dialectical materialism. ${ }^{1}$ Both schools, representing a creative, nondogmatic, open, humanist reconceptualization of the Marxist-Leninist theory, have been considered to be the most promising force in the East European countries for many years, not only for the humanization of existing social institutions but also for a genuine dialogue between Christians and Marxists. ${ }^{2}$ Religion, according to Yugoslav humanist-Marxist philosophers, expresses the suffering and revolt of the oppressed and arises out of the specific conditions of class society. ${ }^{3}$ In addition, religion is an attempt to cope with some unresolved human problems (for example, fear of death and meaning of life).4

${ }_{1}$ Markovic writes: "One of the most fundamental problems in contemporary philosophy . . . is how to make humanism a dialectical philosophy and dialectic a humanist method" (Mihajlo Markovie, "Humanism and Dialectic," in Socialist Humanism, ed. Erich Froom [Garden City, New York: Doubleday Company, 1966], 84).

${ }^{2}$ Yugoslav Marxist theorists, drawing on the writings of the young Marx, advanced one of the most far-reaching critiques of stalinism by calling it "state vapitalism." The stalinist version of Marxism, according to them, resulted in the dominion of totalitarian forms of state machinery and bureaucracy over the proletariat (idem, "Marx and Critical Scientific Thought," Praxis International 3-4 [1968]: 397; Branko Bošnjak and Rudi Supek, eds., Humanizam i Socijalizam [Zagreb: Naprijed, 1963], 7; Gruenwald, "Praxis," 349, 351-352.)

${ }^{3}$ Mojzes, Christian-Marxist Dialogue in Eastern

Europe, 227-228.

4 Ibid. 
Among humanist Marxist philosophers in Yugoslavia, there are some who have never dealt with the religious question in a direct way (or, at best they have only addressed it in a fragmentary way). However, their interpretations of Marx's thought contributed to a creation of the necessary conditions for a better understanding of the religious phenomenon as well as for dialogue with Christians. ${ }^{1}$ others have dealt with the question of religion in a direct way. They have tried to redefine the Marxist concept of religion and have advocated for positive changes in the actual relations between the state and the church in Yugoslavia. ${ }^{2}$ The case of Esad cimic--one of the most prominent contemporary Marxist philosophers of religion ${ }^{3}$--seems most relevant for the purpose of studying the humanist reconceptualization of the dogmatic Marxist criticism of religion.

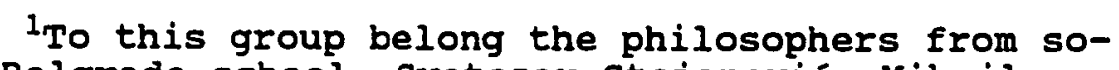
called Belgrade school, Svetozar stojanovic, Mihajlo Markovie, Ljuba Tadic, Zagorka Golubovic, Branko Horvat as well as from Zagreb circle, Gajo Petrovic, Predrag Vranicki and Rudi supek.

${ }^{2}$ To this group belong Esad Ćimic, Branko Bošnjak, Zdenko Roter, Srdjan Vrcan, Andrija Krešic, Marko Kerševan, Stefica Bahtijarevic and Nikola Skledar.

${ }^{3}$ For bibliographical data on ćimić, and a description of the main traits of his philosophy, see below, chapter 3 . 
11

The Case of Esad cimie

Cimic is one of the founders of the modern Marxist philosophy of religion in Yugoslavia. ${ }^{1}$ He does not belong directly to neither the Zagreb or the Belgrade humanist Marxist school.2 However, ćimic's work may be seen as a great contribution to both of them. His criticism and rejection of some important aspects of dogmatic Marxist criticism of religion caused a strong reaction from the dogmatic side. ${ }^{3}$ The fact that Eimic's views of religion were defined as unorthodox by dogmatic Marxists ${ }^{4}$ makes him an interesting case and gives one an opportunity to reflect on the question of the dogmatic-humanist Marxist controversy in regard to the religious phenomenon. The analysis cf his teachings on religion also provides an opportunity for the evaluation of the significance of humanist reconceptualization of the dogmatic Marxist concept of religion for the Christians.

${ }^{1}$ For further information see Fuad Muhic, review of Socijalisticko Društvo i Religija, by Esad ćimié, in Gledista 8 (1967): 809-812; and Mislav Kukod, review of Drama Ateizaciie, by Esad Ćimic, in Naše Teme 30 (1985): 605-607.

${ }^{2}$ see above, 7-9.

${ }^{3}$ For a more detailed description of cimic's professional pilgrimage and his persecution by the dogmatic Marxists, see below, chapter 3 .

${ }^{4}$ Ibid. 


\section{Purpose of the study}

The purpose of this study is to set forth and to critically analyze and evaluate the concept of religion espoused by Esad ćimiટ in view of his reconceptualisation of dogmatic Marxism. The main questions to be addressed are: (1) How does ćimic reconceptualize the traditional MarxistLeninist criticism of religion and can he still be considered a Marxist? (2) How does his reconceptualized concept of religion relate to Christianity? and ( 3 ) What is the significance of his reconceptualization for both dogmatic Marxism and Christianity? The nature of the data, after the study of cimic's publications, has led me to conclude that the issue under consideration might be addressed most efficiently from the philosophical angle.

\section{Importance of the Issue}

What is the importance of dealing with this subject matter? First, it is important because it is impossible to ignore the phenomenon of Marxism in the modern world. Christian theism cannot avoid taking a position regarding the affirmations of Marxist atheism. It is important to search for the positive and negative aspects of Marxism without fear of the "other." In knowing the "other," Christians will be better able to understand themselves and their raison d'etre. This kind of unprejudiced analysis of 
Marxist ideology is very often lacking in Christian iterature. 1

Second, with the recent changes in the soviet Union and other Eastern European countries it might seem to many in the West that the Marxist understanding of reality is doomed to disappear. Although it is possible that Marxism as a political theory or as economy may be bound to disappear, it seems quite improbable that its criticism of religion, its atheism, will soon (if ever) completely find its way out of the mind of men. Since the Marxist criticism of religion is one of the most advanced atheistic theories, it reaches, in one way or another, beyond the geographical borders of the communist countries where Marxism is an official ideology influencing every contemporary man. Marxism is one of the factors which contributes to the shaping of what is known as the "secular mind."2 Consequently, this dissertation contributes to the closely related issues in the ongoing atheistic-theistic controversy.

Third, as far as the question of the relation of Marxism and religion is concerned, Esad ćimić presently is, especially in Yugoslavia and Eastern Europe, probably one of

\footnotetext{
${ }^{1}$ See Mojzes, Christian-Marxist Dialogue in Eastern Europe, 11-12.

${ }^{2}$ See D. W. Gill, "Secularism, Secular Humanism," Evangelical Dictionary of Theology (1984), 996.
} 
the most influential Marxist philosophers. ${ }^{1}$ He was among the creators of a new form of Marxist analysis of religion which will have far reaching consequences for ChristianMarxist dialogue. ${ }^{2}$ Since, for various reasons, his philosophy is not very well known outside of his native Yugoslavia and Eastern Europe, this work intends, as one of its contributions, to make it available to the readers whose native language is not serbo-croatian.

\section{Review of Literature}

There are four books that Cimic has written which have priority over others ${ }^{3}$ as far as my topic is concerned:(1) Socijalistǐ̌ko Društvo i Religija [Socialist Society and Religion], (2) Drama Ateizacije [Drama of Atheisation], (3) Dogma i sloboda [Dogma and Freedom], and Ateizam kao Povijesni Humanizam [Atheism as a Historical Humanism]. 4 Generally speaking, cimic's approach in these

${ }^{1}$ Roter, Marxism and the Religious Question, 9.

${ }^{2}$ Numerous authors, both from the Marxist and Christian side, point out that ćimic made a special contribution to the better understanding of religious phenomenon from the Marxist perspective. See, for example, F. Muhic, review of Socijalisticko Društvo i Religija by Esad Ćimić, 809-812; T. Šagi-Bunie, review of Socijalisticko Društvo i Religija, in svesci Hrišcanska Sadašnjost 2 (1967): 93-95.

${ }^{3}$ Esad Ćimié, Belgrade, Letter to Antic Radiša, Berrien Springs, 22 May 1989.

${ }^{4}$ Idem, Socijalisticko Društvo i Religija [Socialist Society and Religion] (Ćimic's doctoral dissertation); Drama Ateizacije [Drama of Atheization] (Belgrade: Srboštampa, 1984); Dogma i Sloboda [Dogma and Freedom] (Belgrade: Niro 
works is to speak neither for nor against but about religion. He criticized the "dogmatic negation" of religion and perceived that both the religiosity and the atheism of the new generation are less stereotyped and spiritually richer. ${ }^{1}$

The other four books that ćimic wrote (Praksa i Religija [Praxis and Religion], Uvod u Marksizam [Introduction to Marxism], Covjek na Raskršcu [Man on the Crossroad], and politika kao sudbina [Politics as Destiny]) deal in one way or another with the question of the relation between religion and Marxism (that is, the theisticatheistic controversy). ${ }^{2}$ In addition to these books, cimić has written a number of articles which deal in a very direct way with the topic. ${ }^{3}$

"Knjizevne Novine," 1985); and Ateizam kao Povijesni Humanizam [Atheism as Historical Humanism] (Zagreb: Školske Novine, 1988).

${ }^{1}$ Idem, Drama Ateizacije, 232.

${ }^{2}$ Idem, Praksa i Religija [Praxis and Religion]

(Sarajevo: Radnicki Univerzitet "Djuro Djakovic," 1960); Uvod u Marksizam [Introduction to Marxism] (Belgrade: Kultura, 1975); Covjek na Raskršcu [Man on the Crossroad] (Sarajevo: Svjetlost, 1975); Politika kao sudbina [Politics as Destiny] (Belgrade: Srbija, 1982).

'cimic's articles are listed in the bibliography. Some of the journals and periodicals to which cimic has contributed are: Mlada Hercegovina [1954], Odjek [19651969 ], Filozofija [1965], Preqled [1966-1974], Politicka Misao [1967], Lica [1968], Sociologija [1969-1988], Teorija $i$ Praksa [1969], Naše Teme [1970-1987], Sociološki Pregled [1970-1983], Život [1970], Ideje [1971], Kultura [19711985], Pogledi [1971-1984], Ateismo e Dialogo, Italy [1972], Encyclopedia Moderna [1972], ovdje [1972], Obelezja [1972], Kulturni Radnik [1973], Bagdala [1974], Gledista [1976- 
As far as secondary source material is concerned, a number of book reviews and articles react to the ideas of Esad Ćimic. ${ }^{1}$ Besides these, four doctoral dissertations were very helpful in the course of this investigation. ${ }^{2}$ In

1988], Revija za Sociologiju [1978], Aroumenti [1979], Marksistiłko Obrazovanje [1979-1988], Pitania [1980], Journal of Ecumenical Studies, Temple University Philadelphia [1985-1988], Filozofska Istrazivanja [1985], Kniiževne Novine [1983], Kniizevna ReC [1983].

${ }^{1}$ some of the important book reviews and articles about cimic's philosophy are (the rest is listed in the bibliography): I. Bojovic, review of Socijalisticko Društvo i Religija, by Esad Cimic, In Gledišta 8 (1967): 1650-1652; C. Sardelic, review of Socijalisticko Drustvo i Religija, by Esad Ćimic, In Revija za Sociologiju 2 (1972): 103-104; V. Premec, review of Drama Ateizacije by Esad cimic, In Encyclopaedia Moderna 6 (1971): 93-94; Z. Jurasek, review of Drama Ateizacije by Esad ćimic. In Revija 12 (1972): 71-72; M. Oršolie, "La sociology religieuse d'innspiration marxist en Yougoslavie," International Review of Socio-Religious Studies 20 (1973): 1; F. Muhic, review of Socijalisticko Društvo $i$ Religija by Esad ćimic, 809-812; F. Muhic, review of Drama Ateizacije by Esad ćimic, in Odjek 24 (1971): 16; T. Šagi-Bunie, review of socijalisticko Drustvo i Reliqija, 93-95; Marko oršoliદ, "Marksistiðka Sociologija Religije u Jugoslaviji," Revija za Sociologiju 2 (1971): 53-59; N. Kecmanovic, review of Drama Ateizacije by Esad ćimic, in Gledista 26 (1975): 211-213; N. Skledar, review of Drama Ateizacije by Esad cimic, in Filozofska Istrazivanja 5 (1985): 163-165; M. Kukoč, review of Politika kao Sudbina by Esad Ćimic, in Socioloski Preqled 28 (1984): 110-112; Kukoð, review of Drama Ateizacije, 30: 605-607; and L. Rupcic, "Atheismus und Religion," Königsteiner Studien 19 (1973): 150-153.

2 on the basis of bibliographical sources it is possible to determine that no doctoral dissertation has been written on cimic. The most recent biographical source which lists the bibliographical entries on religion, church and atheism in Yugoslavia is written by Bosiljka Milinkovic, Bibliografija Radova o Religiji, Crkvi i Ateizmu 1945-1985 (Zagreb: stvarnost, 1985). Ivica Mastruko wrote a small biography of Esad ćimic in which he lists all the works written by ćimic as well as those written about him (Ivica Maštruko, cimić, Esad, in Hrvatski Biobibliografski Leksikon [Zagreb: Jugoslovenski Leksikografski Zavod, 1990], 58-62). 
1967, Ross Johnson wrote a dissertation entitled "The Dynamics of Communist Ideological Change in Yugoslavia: 1945-1953"1 in which he primarily deals with political and ideological changes which took place after the Yugoslav Communist Party had broken its relation with the communist Party of the Soviet Union. Although this dissertation is not of prime importance for the present work, since it covers the period in history (1945-1953) when the humanist movement within the Yugoslav Communist Party did not yet exist, it is helpful as a background for a better understanding of dogmatic Marxism.

In 1971, Gruenwald wrote a dissertation entitled "Humanism and Marxism: The Yugoslav Perspective" in which he contends that Yugoslav Marxist theory is the most radical, liberalized, and humanized among Communist Party states. 2 He continues by saying that the Yugoslav brand of Marxism in its critique of stalinism and its insistence on an independent road to socialism has had a far-ranging impact on other Eastern European countries, the Soviet Union, as well as on the developing nations of the Third World. ${ }^{3}$ This dissertation was very helpful for the present work

${ }^{1}$ A. Ross Johnson, "The Dynamics of Communist Ideological Change in Yugoslavia: 1945-1953" (Ph.D. diss., Columbia University, 1967).

${ }^{2}$ Gruenwald, "Humanism and Marxism: The Yugoslav Perspective," 233-241.

${ }^{3}$ Ibid. 
because it describes and analyzes the milieu in which cimic developed his new interpretation of the Marxist concept of religion. Equally important is Sher's dissertation "Praxis: Marxist Criticism and Dissent in Socialist Yugoslavia," 1 where he examines the theory and practice of a group of Yugoslav intellectuals whose public life, between 1964 and 1975, centered around the Marxist philosophical journal Praxis. Shenk in his dissertation "The Social Role of Religion in Contemporary Yugoslaviall writes that although the Marxist-Leninist tradition has tended to isolate religious groups from influence on political affairs, there is, in Yugoslavia, an increasingly explicit statement of public interest in the positive contribution to the socialist society which religious communities may make. ${ }^{3}$

\section{${ }^{1}$ Gerson S. Sher, "Praxis: Marxist Criticism and} Dissent in Socialist Yugoslavia" (Ph.D. diss., Princeton University, 1975).

${ }^{2}$ Norman Gerald Shenk, "The Social Role of Religion in Contemporary Yugoslavia" (Ph.D. diss., Northwestern University, 1987).

${ }^{3}$ Shenk, iii. Beside these four dissertations there are three others written on some of the aspects of the Christian-Marxist dialogue in Yugoslavia and they are also important for the present study. Tomo Vereš, Dominican friar and professor of theology in Dubrovnik, in his dissertation (Tomo Vereś, "Filozofsko-Teološki Dialog s Marksom" [Ph.D. dissertation, Teološki Fakultet u Zagrebu, 1970]) examined the unity of thought and praxis in Karl Marx. Another doctoral dissertation was published in Italy and in Latin by a Franciscan friar, Jakov R. Romic (Jakov R. Romic, De Dialogo Inter Marxistas et Chritians [Vicenza, Italy: Libreria Internazionale Edizione Franciscane, 1972]). He carefully explored the thinking of Marx, Engels, and Lenin, seeking for points of contact in the dialogue. According to him the vision of monolithic future which 
This work was beneficial to the present study in pointing to the possible ways of collaboration between Christians and Marxists. Besides the primary source material and these dissertations, a rich body of material exists on the relation of the Christian understanding of reality and that of Marxism.

\section{Research Methodology}

The methodology to be followed aims at the task of describing and analyzing the writings of Esad cimic from the perspective of the humanist reinterpretation of the dogmatic Marxist-Leninist criticism of religion. First, it requires a description of the general personal and ideological background from which his philosophy develops. Second, an analysis relating and comparing his ideas with those of other Marxist philosophers is to be done in order to discover similarities and differences.

The writings of Esad ćimic are described and analyzed topically. This helps to uncover the central components of his criticism and evaluation of the dogmatic Marxist concept of religion. It also helps to reveal the

excludes the possibility of the survival of Christianity and the barriers erected against Christian participation in social change stand in the way of the dialogue. Stjepan Sirovec in his dissertation (stjepan sirovec, Ethik und Metaethik im Jugoslawischen Marxismus [Paderborn: Ferdinand Schöningh, 1982]) questioned the possibility of Marxist ethics at all because ethics is a Christian characteristic. He concluded that there is a Marxist ethics on the social level but not on the individual level. He argued in favor of the Christian-Marxist dialogue. 
internal consistencies and inconsistencies of his work as well as the influences which might have been at work in the development of his thought. We examine all available primary sources, published and unpublished (correspondence, papers, and recordings of speeches). 1 In addition to the primary sources, relevant secondary sources are taken into consideration in order to provide the needed perspective. Once Ċimic's concept of religion is described and analyzed, the task of evaluation is undertaken from the Marxist-dogmatic point of view (trying to determine differences and similarities between Cimic's philosophy of religion with dogmatic Marxist criticism of religion), from the perspective of the inner consistency of his philosophical system, and from the Christian-theistic viewpoint. Evaluation from the christian-theistic standpoint include points of conflict and convergence between ćimiદ's and basic Christian-theistic conceptions.

\section{Limitations}

This work is not a study of all the ideas found in Ćimic's philosophy; primarily, it is a critical investigation of his reinterpretation of the dogmatic criticism of religion. It is also true that it is impossible to understand one aspect of any system isolated

${ }^{1}$ Although personal conversations with the author are not cited they were helpful in clarifying various aspects of cimic's concept of religion. 
from the rest, but the rest must be taken into account insofar as it enlightens che aspect under investigation.

In trying to find the ideological background and articulate the analysis of cimie's philosophy, it is impossible to be exhaustive because of the huge body of material. For this reason, this investigation is primarily limited to the study of the humanist reinterpretation of dogmatic Marxism in Yugoslavia and some other eastern European countries, such as Poland, Czechoslovakia, and Hungary where the humanist contributions were the most advanced. Moreover, Yugoslavia and Eastern Europe represent the most natural context for the study of cimic's philosophy in general and his concept of religion in particular.

\section{outline of the study}

In order to become familiar with the thought context in which Cimic worked, it is important for this study to have, first, an understanding of the main teachings of dogmatic and humanist Marxism. Thus, the second chapter outlines from the historical-philosophical perspective the dogmatic and humanist Marxist views of metaphysics, epistemology, and religion. Understanding of these issues is important because they help to properly locate the Yugoslav situation, in general, and Esad ćimic, in particular, in their ideological and historical context. This chapter also includes a short analysis of the works of "praxis school" and other Marxist philosophers in Yugoslavia 
who contributed to the creation of the new shape of Marxism. These works constitute the closest background for cimie's philosophy.

Chapter 3 attempts to discover Ćimiés experience during his formative years, his professional pilgrimage, the starting point of his philosophy, important shift, and the theoretical base of his philosophy. These issues are important for the proper perception of ćimic's concept of religion and for discerning his approach to its reconceptualization.

Chapter 4 covers cimic's reconceptualization of the dogmatic Marxist criticism of religion. Such issues as ćimie's criticism of basic approaches to religion in the context of socialist societies, his concept of religion as alienation and its sources, and his view about the existence of different dimensions in the religious phenomenon contribute to a clearer comprehension of how he reshaped the dogmatic Marxist concept of religion.

The main focus of chapter 5 is cimic's own concept of religion. It deals with his view regarding the limited scope of Marx's critique of religion, his formulation of religion "per se," religion as socio-historical fact, and religion as anthropo-psychological structure. In addition, it analyzes ćimic's concept of atheism, some basic ideas of his philosophy closely related to his concept of atheism and religion, and his view of self-management. On the basis of 
the analysis of these issues it is possible to evaluate cimie's concept of religion.

Chapter 6 evaluates Ćimic's reconceptulized concept of religion from the dogmatic Marxist viewpoint, from the perspective of inner consistency in his philosophical system, and from the Christian-theistic standpoint. The evaluation from the dogmatic Marxist perspective reveals the major similarities as well as differences between cimic's and dogmatic Marxist positions. The evaluation of the inner consistency of ćimic's philosophical system points to some discrepancies in his system which were discovered in the process of this investigation. Finally, the evaluation from the Christian-theistic viewpoint includes some points of conflict and convergence between ćimie's and Christiantheistic conceptions.

The "General Conclusion" summarizes the main findings of this research and underlines the significance of Ćimie's views for dogmatic Marxism and Christianity. It also addresses the challenge that cimic's work represents for Christians. 
CHAPTER II

\section{HISTORICAL BACKGROUND TO THE PROBLEM}

In order to be able to properly understand cimic's concept of religion as well as his philosophy in general, it is necessary to describe and analyze some basic concepts of two main schools of interpretation of Marxist thought, namely, dogmatic and humanist. ${ }^{1}$ The concepts of metaphysics and epistemology, which are fundamental for both dogmatic and humanist Marxism are discussed because they provide the basic presuppositions for the understanding of the phenomenon of religion in Marxism. ${ }^{2}$ Thus, the purpose

${ }^{1}$ Mojzes, Christian-Marxist Dialoque in Eastern Europe, 222-229; Neil McInnes, The Western Marxists (New York: Library Press, 1972), 7; David McLellan, Marxism after Marx (New York: Harper \& Row, Publishers, 1980), 1; see also above, 1-5.

${ }^{2}$ The dogmatic and humanist Marxist concepts of metaphysics and epistemology are described and analyzed only to the extent they pertain to the better understanding of the Marxist concept of religion. Thus, it seems logical to present first a comprehensive picture of what there is in the world (metaphysics), according to dogmatic and humanist Marxists, and then discuss the origins, the presuppositions, the nature, and the extent of the knowledge of that reality (epistemology). This order does not have any special implication for the understanding of the religious question in Marxism but is inspired by the definition of metaphysics as being "the most fundamental and the most comprehensive of inquires" (see W. H. Walsh, "Metaphysics, Nature of," The Encyclopedia of Philosophy [1967], 5: 300-301). 
of this chapter is to set forth the basic teachings of these two main interpretations and to try to determine the cause of this diversity in Marxism. This will lead us closer to a better understanding of the problem of ambiguity in Marx's thought and to the implications of this ambiguity for the Marxist understanding of the religious phenomenon. special attention is given to the humanist Marxist thought in Yugoslavia because it represents the immediate historical and ideological context for the work of cimic and it enhances our understanding of his concept of religion.

\section{Dogmatic versus Humanist Marxism}

The intellectual line of dogmatic Marxism goes from Engels (1820-1895) to Kautsky (1854-1938), Plekhanov (18561918), Bukharin (1888-1938), and Lenin (1870-1924), and was adopted as the official doctrine by the Soviet Union and all the communist states. 1 Dogmatic Marxism was provided with the philosophical concepts by drawing the metaphysical and epistemological implications from the notion of dialectics of the historico-social process as conceived by Marx. ${ }^{2}$

\footnotetext{
${ }^{1}$ Robert A. Gorman, "Introduction," Biographical Dictionary of Marxism (1986): 9; McInnes, The Nestern Marxists, 7-15; Laszek Kolakowski, Main Currents of Marxism, 3 vols. (Oxford: Clarendon Press, 1978), 3: 1-25.

${ }^{2}$ Neil McInnes, "Marxist Philosophy," The Encyclopedia of Philosophy (1967), 5: 174-176. Viewed from the perspective of the historical origin of the concepts "historical" and "dialectical" materialism, "historical" materialism is the earlier portion. In the 1840 s Marx had already worked out his materialist concept of history which forms the nucleus of historical materialism. only thirty
} 
Hegel's triadic dialectic of thesis, antithesis, and synthesis as an law of cosmic development was applied to nature as well as to the human mind. 1

Two most important moments of the dogmatic Marxist theory of the society are: (1) the supremacy of material substructure over ideational superstructure (science, philosophy, law, ethics, religion); and (2) the

years later Engels undertook the attempt to prove the application to the natural world of those same dialectical laws of development which Marx had already expounded as an explanation for historical-social development. The term "dialectical materialism" was created by Engels and comprises the theoretical philosophy of Marxism, that is, logic, ontology, and epistemology of Marxism. The term "historical materialism" was created by Plekhanov and involves the application of the basic laws of dialectical materialism to the sphere of social development of history. It comprises ethics, politics, and philosophy of history. However, sometimes the term dialectical materialism is used for the fundamentals of Marxism as a whole (Gustav Wetter, "Dialectical Materialism," Sacramentum Mundi [1968], 3: 426; H. B. Acton, "Dialectical Materialism," The Encyclopedia of Philosophy [1967], 2: 389).

${ }^{1}$ Although Marx and Engels criticized and rejected Hegel's idealistic assumptions, they, however, embraced his concept of the triadic dialectic, that is, thesis, antithesis, and synthesis. Dialectic, according to Hegel, is the necessary structure of the reality which is rational. Absolute Spirit is all that is. In affirming himself (thesis), Absolute spirit necessarily affirms the other than self (antithesis) in the form of the world. Absolute spirit achieves the fullness of self-identity in the overcoming of the contradiction between himself and the world (synthesis). This is the ultimate fulfillment of rational process within history. Marx claimed to have turned Hegelian dialectic upside-down but to have accepted its rational structure. For him, dialectic consists of the contradictory structure of capitalist society which by affirming itself as capitalist (thesis) generates the proletarian class which represents the opposition of the bourgeois class (antithesis). This contradiction can be resolved only in a communist society (synthesis) (ibid., "Dialectical Materialism," 389-394; Wetter, 421). 
deterministic significance of the development of productional forces as the economic base of the society for the total social development. 1 with this interpretation, Marxism becomes a closed system providing a coherent explanation which subordinates the complex phenomenon of human society under the laws of matter ${ }^{2}$ and from then on involves the danger of totalitarianism. ${ }^{3}$ Thus, it becomes

\footnotetext{
${ }^{1}$ The basic idea of the historical materialism, according to dogmatic Marxists, is that man is a historical being, and history and historical progress exist because human beings want to satisfy their needs. There are two levels of man's productional activity, namej.y, his relation to nature and to other men. Thus, the term "productional forces" may be described as the relation of man to nature. The term "relations of production" denotes the mutual relations of men with each other in the process of production, primarily the division of labor, the conditions of exchange and the distribution of material goods. The principle nature of each type of these relations is the form of ownership of means of production. The distinctive essence of a given society in a given period is the "mode of production" which includes the unity of the "productive forces" and "relations of production." Furthermore, the mode of production, that is, substructure is in causal relation with superstructure. The superstructure is formed of political, philosophical, ethical, aesthetical, and religious theories. Thus, the substructure causally determines superstructure (ibid., 427).

2 The notion of "matter," for Marxism in general, is a philosophical category which designates the "objective reality" given to man in his sensibilities. It provides the connecting link between the Marxist concept of history and nature and changes its meaning from one sphere to another. In relation to the Marxist view of history, "matter" refers to the economic forces or mode of production. In its relation to nature it refers to "mater in motion" as a basic ontology (see Arthur F. McGovern, Marxism: An American Christian Perspective (Maryknoll: Orbis Books, 1987], 259).

$$
{ }^{3} \text { See McInnes, "Marxist Philosophy," } 175 .
$$
}


natural to move towards an aggressive militant modus

operandi and to end with stalinism. 1

Humanist Marxism has its beginnings in the Hegelian idealist interpretation of Marx's work ${ }^{2}$ which flourished in the 1920s among those Marxists who opposed the idea of the supremacy of substructure over superstructure and the deterministic significance of the economic base for the total social development. ${ }^{3}$ Dogmatic Marxism, according to

\footnotetext{
IIbid., 174-175.

2It is the view, adopted by many Marxists in the 1920s, according to which Marx's thought was basically inspired by Hegelian philosophy (see Kolakowski, 1: 222, 263).

${ }^{3}$ See McInnes, "Marxist Philosophy," 175. The origins of humanist Marxism go back to the work of Antonio Labriola (1843-1904) from Italy. Labriola viewed Marx's work in the light of Hegelian idealism and argued that, according to Marx, history consists of free action selfconsciously reflecting history's rational evolution. Rosa Luxemburg (1870-1919), strategist and political economist of German Communist Party, wrote that although revolution is inevitable it occurs only when workers self-consciously realize it. Antonie Pannekoek, Dutch astronomer and communist, supported the idea of workers' autonomy, that is, the need for the proletariat to think and act for itself and not on party orders. Jean Jaurès (1859-1914), French scholar and politician, wrote about Being as a universal whole, encompassing every level of physical and social organization that evolves into harmony and oneness. Being unifies thought and external reality. Karl Korsch (18861961), German Marxist, argued that there is no objective material reality independent of living human beings. For Antonio Gramasci (1891-1937), a leader of the Italian Communist Party when Mussolini gained power, praxis reflects and expresses a universal pattern of historical development. History, for him, is a product of practical activity, human will (see idem, The Western Marxists, 22-28; Robert A. Gorman, Neo-Marxism: The Meanings of Modern Radical ism [Westport, Connecticut: Greenwood Press, 1982], 85-115; Kolakowski, Main Currents of Marxism, 1: 220-300).
} 
humanist Marxists, overlooks the deep philosophic analyses of human beings and the world found in Marx's works (for instance, Philosophic and Economic Manuscripts of 1844, The Theses on Feuerbach) which are in contradiction with the economic-deterministic approach of the dogmatic Marxist concept of historical materialism. Because of that, humanist Marxists attempted to establish a different type of anti-dogmatic historical materialism which takes into consideration "the full complexity of a peculiar relation between material and ideational productions." 1 Material and ideational, that is, substructure and superstructure, must be seen in their "dialectical conjunction, expressed as duality of two equal poles of a unique producing of historical world by very human being."2 Consequently, in historical materialism, as understood by humanist Marxists, instead of strict dichotomy substructure-superstructure, dynamism of economic structure is emphasized. Economic structure, integrated with all other social phenomena, forms a movable totality that cannot be rigidly divided from superstructure. ${ }^{3}$

\footnotetext{
${ }^{1}$ Nikola skledar and Mislav Kukod, Variation of Historical Materialism in Yugoslav Sociology of Religion, paper presented at "Postdiplomskom Studiju Humanistickih Znanosti u Dubrovniku," April 24, 1988, 3.

2 Ibid.

Irbid.
} 
Dogmatic Marxism, according to humanist Marxists, has incorrectly understood the reiation between the substructure and superstructure by considering human thinking to be nothing but a mechanical reflection of the mode of production. ${ }^{1}$ This kind of passive, impersonal approach to history seemed in contradiction with the view of worker's responsibility for the historical development. 2 Revolution is not caused by laws of matter but by workers who rebel after subjectively realizing that capitalism destroys their essential humanity by transforming them into something they are not. Thus, humanist Marxists attempted to revive the following concepts: (1) revolution cannot be materialized without workers, ${ }^{3}$ (2) emphasis must be on

${ }^{1}$ See McInnes, The Western Marxists, 22-28; Gorman, Neo-Marxism: The Meanings of Modern Radicalism, 85-115.

${ }^{2}$ Humanist Marxists argue that man's activities were originally purely biological functions (for instance, hunting and killing the prey). However, at the very beginning of history these functions changed into "activity," that is, praxis. Praxis may be understood as actions by which man voluntarily alters his environment, brings it into line with his developing needs, and humanizes the world by putting forth his own potentialities (see Wetter, 427 ).

${ }^{3}$ That revolution cannot be materialized without workers means, for the humanist Marxists, that the workers' free will and subjective reflection play an important role in the dialectical development of history. However, humanist Marxists differ from the dogmatic Marxists in their understanding of the concept of "dictatorship of the proletariat" which is closely related to the role of workers in history. For the dogmatic Marxists, "dictatorship of the proletariat" means that in the first phase of revolution the proletariat needs state power, the centralized organization of force to crush the resistance of the exploiters for the purpose of guiding the masses of population in the process 
31

human essence, 1 and (3) subjective cognition of human beings must be reemphasized. ${ }^{2}$ Dogmatic Marxism was, for humanist Marxists, a distortion of Marx's thought and, thus, they decided to go back to Marx's works and prove that basically Engels and Lenin misrepresented the thought of $\operatorname{Marx} .^{3}$

What are the basic philosophical presuppositions of both dogmatic and humanist Marxists, that is, their metaphysical and epistemological concepts? How do these concepts influence their understanding of the religious phenomenon?

Metaphysics

Dogmatic view. Matter, according to dogmatic Marxists, is the unique or, at least, the primary factor at

of organizing socialist economy. For most humanist Marxists (there are differences of opinion), Marx used the term the "dictatorship of proletariat" to describe the Paris Commune, which defended basic democratic principles such as free speech and free elections. Today's communist countries use the term as ideological justification for bureaucratic and party oppression (see McGovern, 300-304).

1Marx's terms "essential being" or "species essence" denote an ideal or pure state which transcends human subjective cognition and concrete social-historical cognition. It exists as human potential. It is used by humanist Marxists as an a priori category subjectively realized when history's rational evolution is complete (Gorman, Neo-Marxism, 74-85; see also Karl Marx, Grundrisse [New York: Vintage Books, 1973], 172-173, 323-325, 539-542).

2 Ibid.

${ }^{3}$ György Lukacs, History and class Consciousness (Cambridge, Massachusetts: The MIT Press, 1971), 68-79. 
every level of reality: in history, in nature, in the explanation of human life and thought. ${ }^{1}$ The ideas of the human mind, such as God, spirit, and soul, are products of matter. ${ }^{2}$ It is not necessary to explain the existence of matter since it is in itself eternal, indestructible, and uncreated. Science has shown that matter alone can explain the origin of the world and of human race. ${ }^{3}$ 173-174.

1see McGovern, 51-52; McInnes, "Marxist Philosophy,"

2One of the basic assumptions of "idealism" is that ideas determine history. Contrary to this, dialectical materialism argues that ideas are the result of matter, that is, mode of production. However, matter, for dialectical materialism, is the basic reality but not the only one. Dialectical materialism recognizes that human consciousness, that is, psychic phenomena such as thoughts, sensations, and feelings are non-material. In opposition to the dialectical materialism, mechanical materialism, that is, the type of materialism current in the eighteenth century, asserts that all phenomena of nature, including life and mind, can be reduced to the arrangement and rearrangement of material particles. The most complex beings can be nothing but arrangements of the ultimate simple ones. Things and their mental images are regarded as isolated and fixed. Thus, mechanical materialism attempts to reduce ail the phenomena of the higher order to the physical and chemical laws of the inorganic sphere. Dialectical materialism recognizes the irreducibility of the higher phenomena to the laws of the lower order. Mechanical materialism also asserts that the source of movement is to be sought outside the thing being moved. For dialectical materialism, the source of movement is to be found within the moving thing itself, in inner contradictions or in a struggle of opposites. In this way, dialectical materialism attempts to avoid the concept of movement which is understood in the sense of general change or the assumption of a prime mover (Wetter, "Dialectical Materialism," 424-425).

3'Idem, "Marxism," 3:426; see also Acton, "Dialectical Materialism," $2: 389$. 
The motion belongs to the matter by its very nature and, thus, explains the movement and development in the world. Consequently, reality should be viewed as a complex of processes. It is subject to laws which are causal and which impersonally determine human and social phenomena. ${ }^{1}$ The operation of these laws of matter makes the ultimate advent of socialism and communism inevitable. However, dogmatic Marxists are not mechanical determinists. ${ }^{2}$ They urge people to conceive reality by dialectical approach which attempts to grasp things in their interrelationships and in their process of change, conflicts, and contradictions. ${ }^{3}$

\footnotetext{
${ }^{1}$ However, Lenin argued that the objective, necessary character of the laws of history do not in any way obliterate the role of active individuals in history. He deliberately stressed the need for organizing the revolution and for focusing attention on the leading revolutionary force, the proletariat (see Vladimir I. Lenin, "The Three Sources and Three Component Parts of Marxism," in V. I. Lenin: Marx, Engels, Marxism [Moscow: Foreign Language Publishing House, 1951], 78; Materialism and EmpiroCriticism, in A Handbook of Marxism [London: Victor Gollancz, 1935], 641).

${ }^{2}$ Frederick Engels, "Engels to $w$. Borgius in Breslau," in Karl Marx and Frederick Engels: Selected Works (New York: International Publishers, 1968), 704; According to dogmatic Marxists, mechanical materialism overlooks the changefulness, interconnections of things as well as the aspect of process. Thus, mechanical materialism must be superseded by dialectical materialism which grasps the world in all its interconnections, processes, contradictions, and beginnings and endings (Acton, 2: 391; see also Frederick Engels, Dialectics in Nature [New York: International Publishers, 1940], 166-208, 227-228).

${ }^{3}$ Acton, 2: 391; see also Frederick Engels, AntiDüring (New York: International Publishers, 1966), 26; "Introduction to Dialectics of Nature," in Karl Marx and
} 
Humanist view. According to humanist Marxists, reality consists of objective matter and subjects who cognitively work and live. ${ }^{1}$ The dialectical method is the essence of Marxism, and it is a way of comprehending reality as an unfolding, dynamic, inclusive totality that properly relates subjective and objective moments. ${ }^{2}$ This totality has priority over parts. Each part of the social totality when isolated from the totality is an empty abstraction that has physical presence but is dead. Every empirical fact can be properly understood only when perceived in its relation to the whole, totality. ${ }^{3}$

Frederick Engels: Selected Works (New York: International Publishers, 1968), 357.

${ }^{1}$ Lukacs, History and Class Consciousness, 142, 189 ; see also Stanislaw Brzozowski, Idea (Lemberg, Poland: B. Poloniecki, 1910), 7, 119, 154; Kolakowski, Main Currents of Marxism, 2: 236-239; B. S. Milosz, "A Controversial Polish Writer Stanislaw Brzozowski," California slavic studies 2 (1963): 53-61.

${ }^{2}$ Lukacs, History and Class Consciousness, 189-190; see also Gorman, Neo-Marxism, 85, 124-125.

${ }^{3}$ Lukacs, History and class consciousness, 3-15. Lukacs, for instance, writes that the historical totality is composed of partial, dynamically interrelated totalities which express and define lower level mediations of which it is composed and higher level mediations within which it fits. The movement of the totality is composed of all the mediations which are dialectically interrelated. Dogmatic Marxists by ignoring particular social phenomena and by overemphasizing the totality do not understand that "the category of totality does not reduce its various elements to an undifferentiated uniformity, to identity" but that these various elements "are involved in a dynamic dialectical relationship with one another and can be thought of as the dynamic dialectical aspects of an equally dynamic and dialectical whole" (ibid., 12-13). 
Humanistic Marxists condemned the assertion of dogmatic Marxism that there is a causal connection between substructure and superstructure. When Marx wrote that matter determines consciousness, he was explaining the determining connection between the totality and individual consciousness, the general determination of each part by the whole, and not that of the parts to each other. ${ }^{1}$

As far as the question of the future is concerned, most humanist Marxists argue that Marxism does not have an absolute goal for the future. ${ }^{2}$ There is no certainty that communism will ever come about nor that it will be the final period of history. Consequently, the Marxist concept of

${ }^{1}$ See ibid., 18-24; for further information see Brzozowski, Idea, 154; Kolakowski, Main Currents of Marxism, 2: 236-239. Humanist Marxists view humanity historically and understand freedom to be a merging of subjectivity and historically accumulated essentiality (universality) that occurs only at a certain stage in society's material development. For classical idealists (Plato, Descartes, Leibniz, Kant, Hegel), on the other hand, essentiality is an objective, ahistorical quality which transcends temporality. According to humanist Marxists, human nature is inconceivable apart from the global movement of history. For classical idealists, human nature never changes, it is static although humanity lives through various historical stages of ignorance concerning its real dimensions. Essentiality, that is, objective human nature, for classical idealists, takes primacy over man's evolution in history. Humanist Marxists, by emphasizing subjective cognition and human essence (in Marx's terms "essential being" or "species essence") desired to win the workers' loyalty and to strengthen the proletarian revolutionary movement in Europe (Gorman, Neo-Marxism, 74-85; Marx, Grundrisse, 172-173, 323$325,539-542$ ).

${ }^{2}$ There is a wide variety of opinions among humanist Marxists about the concept of the "future." However, most of them argue for an "open future" (see Mojzes, ChristianMarxist Dialogue, 291-294). 
36

future is an open future which offers human beings a limitless number of creative options. ${ }^{1}$

\section{Summary}

For the dogmatic Marxists, reality consists of the material order which is foundation and base of everything existing. History is determined by laws of matter which function impersonally and causally with objective, a priori processes governing the entire universe, including human beings. For the humanist Marxists, reality is totality which includes objective matter and human beings who subjectively perceive that matter. There is a dialectical and not a causal relation between the different parts of the totality.

The dogmatic Marxist assertion that matter is the only reality and that it impersonally determines human consciousness implies that religion (as well as other forms of cultural superstructure) is nothing but the expression of the dominant economic and social relations. According to humanist Marxists, religious phenomenon is not causally determined by material substructure. It is the result of different factors which are in the dialectical interrelationship within the totality. Thus, religion must be understood only in relation to the totality of reality and not separately.

\footnotetext{
${ }^{1}$ See Gardavsky, God Is Not Quite Dead, 208.
} 
Epistemology

Dogmatic view. Man ${ }^{1}$ perceives matter, that is, the physical world, directly by his senses apart from any speculation of any kind. 2 knowledge as well as all human thoughts derive from the sensuous experience and consists of true ideas because the truth involves a correspondence between objective reality and ideas. ${ }^{3}$ Thus, the constitution of consciousness, that is, ideas and notions, is directly interwoven with the historical activity of human beings and appears as the direct efflux of material conditions. 4 "Consciousness can never be anything else but conscious being, and the being of men is their real life process."5 "It is not consciousness that determines life, but life that determines consciousness."6 Accordingly, the mode of production is the only source of knowledge.?

\footnotetext{
"In this paper, the terms "man" and "his" are used to refer to all of human kind and are without sexist significance.

2McGovern, 52; McInnes, "Marxist Philosophy," 174; see also Engels, Dialectics of Nature, 242.

${ }^{3}$ McLellan, Marxism after Marx, 13; see also Engels, Dialectics of Nature, 313 .

${ }^{4}$ See McGovern, 255-262.

${ }^{5}$ Marx and Engels, German Ideology in Karl Marx and Frederick Engels on Reliqion, 73-74.

6rbid. , 74-75.

${ }^{7}$ See McLellan, Marxism after Marx, 13; Frederick Engels, Socialism: Utopian and Scientific (Westport, Connecticut: Greenwood Press, Publishers, 1977), 54; Feuerbach and the End of Classical German Philosophy, in
} 
Knowledge is dialectical because the laws of matter work dialectically. Matter "does not move in the eternal oneness of a perpetually recurring circle, but goes through the real historical evolution." 1 consequently, "a system of natural and historical knowledge which is all-embracing and final for all time is in contradiction to the fundamental laws of dialectical thinking." 2

Karl Marx and Frederick Engels: Selected Works (New York: International Publishers, 1968), 605.

IIlem, Socialism: Utopian and Scientific, 48; see also McInnes, "Marxist Philosophy," 175.

${ }^{2}$ Ibid. Although Lenin, in most cases, shared his views on epistemology with other dogmatic Marxists, he, however, was studiously looking in Engels' writings for scattered ideas such as cognitive "reflection." The reason for this is found in the fact that he was unwilling to accept the logical result of the orthodox materialistic Marxism that human beings are no more than passive, noncreative, social actors. There would be no difference between Marxist materialism and that of materialists before Marx if mind and its content are reduced to physical properties. Probably for that reason, Lenin was not ready to deny mental reality of man altogether, and he described the subject's cognition as "reflective" matter. The situation in czarist Russia as well as Lenin's temperament were irreconcilable with the theory that the role of human beings in history is to meekly await the inevitable revolution. However, Lenin's dualism was criticized as an ineffective materialist defence of subjectivity and intentional action because in affirming their existence he, at the same time, denies their autonomy (see Gorman, NeoMarxism: The Meanings of Modern Radicalism, 42-43); Kolakowski, Main Curfents of Marxism, 3: 154; Acton, 2:394396; see also V. I. Lenin, Materialism and Empiro-criticism, in $\mathrm{V} . \mathrm{I}$. Lenin: Selected Works, ed. The Marx-Engels-Lenin Institute [New York: International Publishers, 1935], 154 ; V. I. Lenin, Materialism and Empiro-Criticism, in Collected Works of V. I. Lenin, ed. V. I. Lenin Institute, 30 vols. [New York: International Publishers, 1927], 13: 155-156). 
Humanist view. The consciousness of human beings, according to humanist Marxists, does not perceive matter directly and passively without any reflection. ${ }^{1}$ Knowledge derives not only from the sensus experience but also involves human subjectivity as well as influences from other mediations within the totality. Human knowledge is shaped by the totality of reality. Workers perceive cognitively the totality and understand their role in the historical development. ${ }^{2}$

Matter and thought do not reflect or correspond to each other but "they are aspects of one and the same real historical and dialectical process."3 Real knowledge, which is the result of complex interactions within the totality, produces a reflective, subjective awareness of the necessity of revolution and the will to participate in it. 4 Thus, revolution depends on workers cognitively realizing the standpoint of the totality. The truth of all cultures

${ }^{1}$ MCLellan, Marxism after Marx, 158-163; see also Lukacs, History and Class Consciousness, 188-191.

2 Ibid.

${ }^{3}$ Ibid.; see also Gorman, Neo-Marxism, 85.

"Ibid., 100; Lukacs writes: ". . only if the subject (consciousness, thought) were both producer and product of the dialectical process, only if, as a result the subject moved in a self-created world of which it is the conscious form and only if the world imposed itself upon it in full objectivity, only then can the problem of dialectics, and with it the abolition of the antithesis of subject and object, thought and existence, freedom and necessity, be held to be solved" (Lukacs, History and Class Consciousness, 142). 
is a partial manifestation of an increasingly self-evident universal process. 1

\section{Summary}

The epistemology that orthodox Marxist philosophers have developed is a theory of causal reflection. The ideas in one's brain (including religious ideas) are nothing but copies of "real things,"2 reflections or images. Human beings reflect matter passively and their freedom consists of the capacity to act in accordance with the knowledge of the facts. They are only impotent tools in history and their revolutionary role is diffused.

For humanist Marxists, on the other hand, the human mind does not reflect material conditions passively; it is a part of the revolutionary process itself. Knowledge is the result of the complex interactions between different mediations within the totality. Man, as cognitive subject, reflectively and subjectively perceives objective reality, that is, matter.

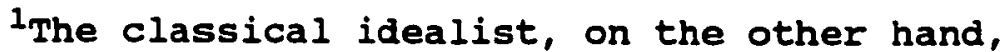
evaluates the truth or falsity of cultures on the basis of a timeless ideal (see Gorman, Neo-Marxism, 123).

"For Plato, for instance, "the real things" designate the world of ideas which provide the reality for the physical objects in the sense world. Physical objects of the empirical world only imperfectly imitate the forms of the real world. For Marx, "the real things" designate primarily the mode of production which includes the productive forces and the relation of production (see Wetter, 427; see also above, 27).
} 
41

If human thoughts are nothing but the reflections or copies of the material conditions, as dogmatic Marxists argue, then the source of religious ideas is to be found in the existing material circumstances. Consequently, this means that the elimination of the class society and economic injustices automatically will bring the religious phenomenon to an end.

However, if human thoughts are shaped by the totality of reality, as humanist Marxists argue, then religion is not only a reflection of material conditions but much more. Religious phenomenon must be approached as a complex phenomenon which expresses some deep needs of human beings.

\section{Religion}

Dogmatic view. The concept of religion, for dogmatic Marxist philosophers like all other activities of man that are classified in the cultural superstructure (ethics, aesthetics, philosophy, and art), is closely related and determined by their concepts of metaphysics and epistemology. This study proceeds with a brief look at the dogmatic view of nature, origin, alienation, and the future of religion.

First, according to the dogmatic Marxist theory of the nature of religious phenomenon, the essence of religion is to be found in human beings' need to objectify their own 
fundamental characteristics in ideal terms. 1 Religion is an indication of man's impotence; it is the emptying of man of all content and the transferring of this content to the distant God. Religion is "the fantastic reflection in men's minds of those external forces which control their daily life, a reflection in which the terrestrial forces assume the form of supernatural forces." 2 Accordingly, on the basis of the presupposition that material order is primary and the foundation of everything existing, dogmatic Marxists argue that the phenomenon of religion is determined by economic conditions. ${ }^{3}$ This is how the concepts of metaphysics and epistemology impact on the nature of religion.

Second, the dogmatic Marxist position as to the origin of religion is based on the presupposition that, in the beginning of human history, religion was the result of man's inability to understand the materialistic nature of the eternal universe surrounding him and his faulty tendency

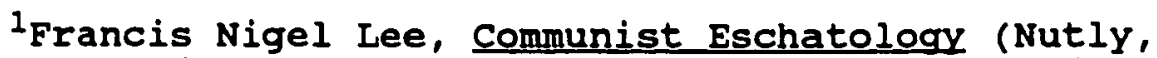
New Jersey: Craig Press, 1974), 558; see also J.P. Reid, "Marxism," Encyclopedic Dictionary of Reliaion (1979), F-N : 2280 .

${ }^{2}$ Engels, Anti-Düring, 344 ; see also Klaus Bockmuehl, The Challenge of Marxism (Downers Grove: InterVarsity Press, 1980), 57-58.

${ }^{3}$ See David McLellan, Marxism and Religion (London: Macmillan Press, 1987), 138-139; Engels writes: "Political, juridical, philosophical, religious, literary, artistic, etc., development is based on economic development" (Engels, "Engels to $w$. Borgius in Breslau," 704). 
to explain it all as a creation of gods. ${ }^{1}$ The forces of nature had presented themselves to man as external, inexplicable, and dominating. ${ }^{2}$ At a further stage of evolution, all these natural forces are supplemented by social attributes of gods which are transferred to one almighty God, who again is nothing but the reflex of man's natural and social surroundings. ${ }^{3}$ In the bourgeois society, men are dominated by the economic conditions created by themselves. These economic conditions present themselves to men as external forces, therefore, mankind does nothing but only proposes and God disposes. 4 Consequently, religion is the expression of the real distress caused by the corrupted and perverted socioeconomic conditions of the class society. 5

\section{9.}

${ }^{1}$ See Lee, 585; McLellan, Marxism and Religion, 36-

${ }^{2}$ See Engels, Anti-Düring, 344. "At the beginning consciousness is of course only consciousness of the immediate sensuous surroundings and consciousness of the limited connection with other persons and things outside the individual becoming conscious of itself; at the same time it is the consciousness of nature, which at the beginning confronts man as a completely alien, almighty and unassailable power to which man's attitude is a purely animal one and to which he submits like a beast; it is therefore a purely animal consciousness of nature [nature worship]" (Marx and Engels, German Ideology, 75).

${ }^{3}$ Engels, Anti-Düring, 345 .

4 Ibid.

${ }^{5}$ Bockmuehl, 57-58. 
Third, religion is an alienating force according to dogmatic Marxist thinking. Religion can be criticized on two levels: individual and social. on the individual level, every kind of subjective religious attitude is an illusion and sickness. Theoretically it should be exposed as unrealistic and false. ${ }^{1}$ Thus, for instance, the ontological argument, as well as other arguments for the existence of God, are logically fallacious because they are only an illusory product of human consciousness, a proof rather for the nonexistence of God. 2 Man projects an imaginary idea of himself by inferring from the evil and emptiness of this world a divine being who is a guarantor of a better existence. When the questioner posits the question of creation, for instance, he must necessarily contradict himself by annihilating himself and dissolving the premises of the real beings that constitute the universe. ${ }^{3}$

As far as the social aspect of religious alienation is concerned, dogmatic Marxists argue that Feuerbach's critique of religion is insufficient because he failed to

\footnotetext{
${ }^{1}$ See Reid, 2280; see also Lee, 560-566.

${ }^{2}$ since human consciousness is only a reflection of. economic reality and is determined by it [metaphysics], all knowledge is riveted to the natural and precludes any supernatural knowledge (epistemology) (ibid).

${ }^{3}$ However, most of the dogmatic Marxists accept Marx's assertion that it would be a waste of time to formulate a new, full-scale theoretical critique of religion since Feuerbach had completed the antitheist critique (see McGovern, 246-251).
} 
see religion as the ideological expression of a real socialeconomic alienation which is prior to the emergence of religion. Although Marxism is antitheistic and antireligious, it is also opposed to all forms of alienation. Thus, antitheism and antireligion should be incorporated in a critique of political economy. The radical change of the social conditions will thus eliminate religion. ${ }^{1}$

since everything is involved in the dialectical process of change and, thus, there are no fixed points in reality, religion (as well as ethics and aesthetics) was changing throughout the history as society was evolving, always defending the privileges of the ruling class. ${ }^{2}$ For that reason communism abolishes all eternal truths, "it abolishes all religion, and all morality, instead of constituting them on the new basis; it... acts in

\footnotetext{
1Ibid., 250-261; Reid, 2280; Alasdair MacIntire, Marxism and Christianity (New York: Schocken Books, 1968), 103-116.

2Ibid., 103; Engels writes: "Does it require deep intuition to comprehend that man's ideas, view and conceptions, in one word, man's consciousness, changes with every change in the conditions of his material existence, in his social relations and his social life? What else does the history of ideas prove, than that intellectual production changes its character in proportion as material production is changed? The ruling ideas of each age have ever been the ideas of its ruling class" (see Karl Marx and Frederick Engels, Manifesto of the Communist Party, in Karl Marx and Frederick Encels: Selected Works [New York: International Publishers, 1968], 51).
} 
contradiction to all past historical experiences." 1 God is primarily a complex of ideas caused by the oppressing and enslaving social conditions which tend to perpetuate this submissiveness and to deaden the force of the class struggle. ${ }^{2}$

Fourth, in the future society, man will be in the position not only to propose but to dispose. The external forces which are reflected in religion, as well as the religious reflection itself, will vanish because there will be nothing left to cause this reflection. ${ }^{3}$ God will be abolished and religion will disappear. The progress of materialist science will render completely redundant the idea of God, which is just another name for ignorance. With the possibility to control the process of production that will be afforded by the advance of natural science, it would become impossible to maintain "this senseless and unnatural idea of a contrast between mind and matter, man and nature, soul and body," an idea which arose after the decline of classical antiquity and attained its highest elaboration in

\footnotetext{
IIbid.

${ }^{2}$ see V. I. Lenin, "Basic Principles," in Lenin Reader, ed. Stefan T. Possony (Chicago: Henry Regnery Company, 1966), 91. 581.

${ }^{3}$ McLellan, Marxism and Religion, 54-56; Lee, 574-
} 
Christianity. ${ }^{1}$ There will be no need for religion and its consolation, for man will be inherently happy. ${ }^{2}$

Thus, for dogmatic Marxists, all religions and churches are instruments in the hands of capitalists that serve to defend the exploitation of the working class. ${ }^{3}$ Marxism is materialism and because of that, it is "relentlessly hostile to religion"4 and it "must combat religion."5 A Marxist in his fight against religion should not remain on the purely theoretical level but should attempt to explain it "concretely, on the basis of class struggle which is going on in practice." 6

Humanist view. In general terms, for humanist Marxists, Marx's analysis of religion is limited, fragmentary, and incomplete. ${ }^{7}$ It is oversimplified and the result of pragmatic considerations and historical

\footnotetext{
1Engels, Dialectics of Nature, 293.

${ }^{2}$ Lee, 586.

${ }^{3}$ see V. I. Lenin, "Attitude of the Workers' Party
} towards Religion," in V. I. Lenin: Marx Engels Marxism, ed. Marx-Engels-Lenin Institute (Moscow: Foreign Languages Publishing House, 1951), 274.

${ }^{4}$ Ibid. , 276.

5 Ibid. , 277.

6Ibid., 280; Lenin writes: "A Marxist must be a materialist, $i . e .$, an enemy of religion; he must be a dialectical materialist, i.e., one who puts the fight against religion not abstractly . . . but concretely" (ibid., 279-280).

Europe, 227.

${ }^{7}$ See Mojzes, Christian-Marxist Dialoque in Eastern 
influences. ${ }^{1}$ since the establishment of the socialist societies, many new issues arose concerning the relation of Marxism and Christianity which should and must affect the Marxist concept of religion. ${ }^{2}$

Although humanist Marxists widely differ among themselves as to their criticism and evaluation of the dogmatic Marxist concept of religion, a number of common points exist among them on the bases of which their concepts of religion may be classified as humanists. Humanist Marxist's views of the nature, origins, alienation, and future of religion greatly differ from the dogmatic Marxist understanding of religion.

Thus, for instance, one of the basic assertions of humanist Marxists on the nature of religion is that religion is an erroneous picture of the world that came into existence under the influence of different objective but also subjective elements. The objective elements are seen in the fact that religion is the mirror of man's revolt against the misery of social environment and an attempt to overcome that. ${ }^{3}$ The subjective elements of religious illusion are seen in man's attempts to cope with some

\footnotetext{
${ }^{1}$ Ibid.

${ }^{2}$ See Machovec, 21.

${ }^{3}$ Mojzes, Christian-Marxist Dialogue in Eastern Europe, 227; see also Marko Kerševan, "Odnos Komunista Prema Religiji," Naše Teme 19 (1975): 887-891.
} 
unsolved, perennial problems, such as the fear of death, the meaning of life, and personal traumas. ${ }^{1}$

Humanist Marxists do not accept the dogmatic Marxist concept of the origin of religion. They condemn dogmatic Marxism for postulating direct, causal relationship between base (socio-economic substructure) and superstructure (religion is part of cultural superstructure). ${ }^{2}$ Religious ideas are determined not only by the economic mode of production as the only source of religion but also by aesthetic, political, social, and other forms of social activity, that is, by the totality of social life. ${ }^{3}$

Religion is, in humanist Marxist view, a form of alienation because it consists of a faulty understanding of reality. 4 However, although it may be a form of alienation, dogmatic Marxists do not understand that religion is an essential component of social life and that it is real and important to reflective actors. 5 Moreover,

\section{Europe, 227 . \\ ${ }^{1}$ Mojzes, Christian-Marxist Dialogue in Eastern \\ ${ }^{2}$ Lukacs, The Meaning of Contemporary Realism, 19;} History and Class Consciousness, 3-15, 189-190; for further information see Mojzes, Christian-Marxist Dialoque in Eastern Europe, 227.

$$
\begin{aligned}
& { }^{3} \text { Ibid. } \\
& { }^{4} \text { Ibid. } \\
& { }^{5} \text { Ibid. }
\end{aligned}
$$


for some humanist Marxists, religion is not alienation at all but rather a positive force of social change. ${ }^{1}$ Humanist Marxists argue that religion will continue to survive in any future society because its source is not to be found merely in the socio-economic conditions. 2 In the same vain they suggest that insofar as some aspects of religion contribute to the reinforcement of class divisions, it should be fought by Marxists. However, if religion contributes to the class struggle on the progressive side, Marxists should cooperate with it. ${ }^{3}$ The administrative struggle against religion is nonsense and Marxists should only work to bring about the classless society which would of itself take care of religious alienation. ${ }^{4}$ A brief look at some representative thinkers may be enlightening. 5 Machovec, Czech Marxist philosopher and one of the giants of the Christian-Marxist dialogue of the 1960s, writes that Engels and Kautsky attempted to do away with

\footnotetext{
${ }^{1}$ The view of religion as a form of alienation differs among humanist Marxists. Ćimic attempts to shed light on this problem (Kerševan, "Odnos Komunista Prema Religiji," 888-891).

${ }^{2}$ Gardavsky, God Is Not Ouite Dead, 172; Branko Bošnjak, Filozofija i Kršcanstvo: Racionalna Kritika Iracionalnog Shvacania (Zagreb: Stvarnost, 1987), 362-386.

${ }^{3}$ Ibid.

${ }^{4}$ Ibid.

${ }^{5}$ These representatives probably combine nature, origin, alienation, and future of religion in their own unique way and that is why this study follows the route of individual writers.
} 
Christianity. They tried to explain the phenomenon of religious belief by reference to economic forces and pointed out that "Christianity had begun with the dreamer and ended with a well fed clergy."I However, Marx's concept of the nature of religion is insufficient because "Marx developed his 'atheism' as a critique of the conventional nineteenthcentury representations of God, and should these change, then the genuine Marxist would have to revise his critique." 2 He continues by saying that "twentieth-century theologians have worked out new and more dynamic models for thinking about God, so that often we Marxists do not know whether we are still atheists or not in their regard." 3 Consequently, religion should not be a priori rejected. However, one has to ask: Which of these ideas offers positive and true knowledge about man's being and existence as well as inspiring ideals, models, and norms of value without which even the best-organized, affluent, and technically perfect society remains impoverished and, indeed, barbarous? ${ }^{4}$ He finds similarity between the very essence of Marxism and Christianity by saying that the more one is a Marxist and the more deeply and rigorously a Marxist understands himself and the vastness of the task

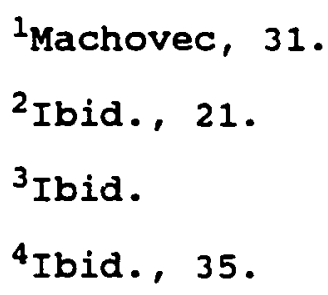


which lie ahead, "the more will he be able to learn from the Judaeo-Christian tradition and to welcome Christians as potential allies and brothers."I

Vitezslav Gardavsky, a Marxist philosopher who taught at the Military Academy at Brno, Crechoslovakia, and has actively participated in the Christian-Marxist dialogue in the 1960s and 1970s, argues that radical Marxism which goes to the roots of its own history will find that these roots include Christianity. Because of that, "Christianity as a religious movement can be altered to fit in socialism, with the tasks it has set itself, and its aims." 2 The story of Jacob (as well as of other typical personalities of Christian faith such as Jesus, Augustine, Aquinas, and Pascal) with its betrayals and vicissitudes reveals the idea of personal identity and choice. This idea, which is opposite to the classical ideas of cosmic harmony and predetermined system, had entered human history and also the minc of a Jew, Marx, who was "more capable than virtually anyone before him of reading the prophecies given in the Bible." 3 Jesus belongs to the same line of tradition

${ }^{1}$ Ibid., 31; see also Mojzes, Christian-Marxist Dialogue in Eastern Europe, 229-230; McLellan, Marxism and Religion, 143-144.

${ }^{2}$ Gardavsky, God Is Not Quite Dead, 15 .

3 Ibid. , 33. 
because he was the first communist and the prime example of successful subjectivity. ${ }^{1}$

In the past, Marxism was anti-clerical and used Enlightenment's rationalism which was nothing but the mere exercise of reason. However, the time has come for Marxist philosophers to make "a searching investigation of everything which attempted, in conditions which were historically inevitable, to establish an order which would give a firm basis to man's existence on earth." 2 Thus, for Gardavsky, it is wrong to presuppose that the roots of religion must be found in the conflicts of economic interests and that it would disappear with the elimination of these conflicts, because some of the reasons for the existence of religious beliefs can be found in the conflict between the interests of citizens and the power of the state. ${ }^{3}$ Therefore, "it is virtually certain that we will go on living in social conditions which foster religion for a long time to come." 4

For humanist Marxists, thus, there is no direct causal relation between substructure and religion. Religious ideas are not passively determined by the laws of

1Gardavsky writes: "Man is the creature who evolves by fighting and by answering the call of the present with a free decision" (ibid., 51).

$$
\begin{aligned}
& { }^{2} \text { Ibid., } 76 . \\
& { }^{3} \text { Ibid., } 172 . \\
& { }^{4} \text { Ibid. }
\end{aligned}
$$


matter; they must be seen as a complex phenomenon resulting from different elements which are dialectically related in the totality of reality. 1

\section{Summary}

The superstructure, that is, ethics, aesthetics, and religion, as well as other philosophical ideas, are interpreted by the dogmatic Marxist philosophers in accordance with their metaphysical and epistemological presuppositions. The ideas of cultural superstructure are nothing more than the expressions of the dominant economic relations and are shaped by material relations. Consequently, society's ruling intellectual force is the dominant economic class. Furthermore, since the material order is the foundation of everything, then religion appears only under the conditions of class society and is nothing but a mystification of natural and material relations. The impulses for man's knowledge come from the objects outside of himself, objects which are independent of himself, and thus, religion is the reflection in man's mind of those forces which control his daily life and which assume the form of supernatural forces. In addition, religion is one of the forms of alienation and spiritual oppression which weighs heavily upon the masses of people. Religion is used

\footnotetext{
${ }^{1}$ see Eduard Bernstain, Evolutionary Socialism (New York: Hartcourt Brace, 1961), 17; see also Lukacs, History and class Consciousness, 3-15.
} 
by the ruling classes to hold exploited classes in passive subjection and, hence, it will disappear completely in the future communist society.

For the humanist Marxists, there are complex

relations between the totality of reality and human subjects, relations that are dialectical and reciprocal. No causal connection exists between base and superstructure, between socio-economic conditions and religion (as well as ethics and aesthetics). Religion is the outcome of the complicated interactions of many different influences in man's existence. It is determined not only by the socialeconomic conditions but by the totality of the social whole. The purely economic causes create only the disposition for the reception of religious ideas, but how these then arise and spread and what form they take depends on the cooperation of a whole series of influences. Thus, in dealing with the phenomenon of religious ideas, it is necessary to use a method of selection from different explanations and ways.

Refusing to accept one of the basic premises of dogmatic Marxism, namely, the passive determination of the human beings by a priori deterministic laws which are built in the very structure of nature, humanistic Marxists argue that religion may be considered as a form of the expression of subjectivity which is not bad as long as it contributes to the class struggle. 
The Ambiquity of Marx's Leqacy

The different interpretations of Marx's work, as expressed in the dogmatic and humanist Marxist views, can be explained in relation to the ambiguity of his philosophy. The inconsistences in Marx's formulations of metaphysical and epistemological concepts resulted in different versions of Marxist philosophy, in general, and in the concept of religion, in particular.

An Example of the Ambiguity of Marx's Philosophy in General

In some of his statements, Marx argued that a human being separated from enviromment is nothing but a package of physical and emotional needs demanding realization. Since all animals have the similar needs, it means that these needs alone do not constitute human nature. ${ }^{1}$ Man, therefore is inextricably bound to his social context. What makes man different is his ability to be aware of the world around him and to be able to creatively interact with nature and with his neighbors in order to fulfill his needs. ${ }^{2}$ The free human activity modifies the nature and creates a new world which develops new needs of man that must be satisfied by additional actions. It means that the productive

\footnotetext{
${ }^{1}$ Karl Marx, "Alienated Labor," in Karl Marx: The Essential Writings, ed. Frederick L. Bender (New York: Harper \& Row, Publishers, 1972), 75.

${ }^{2}$ Ibid., 75-76.
} 
activity of man fuels the motor of history and takes men into the future. 1

Thus, when Marx speaks about reality, he implicitly means human reality because the world in which human beings live is shaped by human consciousness through the creative activity, praxis. Free human action and experience produce the truth in history. Marx writes:

History does nothing; it "does not possess riches," it "does not fight battles." It is men, real, living men, who do all this, who possess things and fight battles. It is not "history" which uses men as a means of achieving--as if it were an individual person--its own ends. History is nothing but the activity of men in pursuit of their ends. ${ }^{2}$

on that basis, Marx analyzed the structure of capitalist society and concluded that the social conditions of existing institutions are destructive and antihuman because they do not promote achieving human potentials and freedom as creative actors. Human beings are alienated, passively defined by the machines and institutions, and history is no longer the product of human praxis. 3 Human praxis, that is, man's "essential nature" or "species essence" in the early period of Marx's work (1839-1846), seems to play the role of an a priori category subjectively

${ }^{1}$ See Marx and Engels, The German Ideology, 57.

${ }^{2}$ Karl Marx, Selected Writings in Sociology and Social Philosophy, ed. T. B. Bottomore and Maximilien Rubel (London: Watts \& Co., 1956), 63.

3Idem, "Alienated Labor," 75.

${ }^{4}$ see above, 31 . 
realized, politically as well as economically, only when concrete life conditions become reasonable, reflecting humanity's collective interests.'

However, 2 Marx's writings also include some

different concepts of metaphysics and voluntaristicdeterministic dilemma. He writes that the material order is the basis of what is real. ${ }^{3}$ when he writes about the influence of the matter on the social behavior of human beings and on politics, he states that "one is too easily tempted to neglect the objective character of the relations and to explain everything from the wills of the persons acting."4 There are, for Marx, laws which "determine both the actions of private persons and of individual authorities which are as independent of the will as breathing." 5 These laws of historical motion "can be determined with almost the

${ }^{1}$ Karl Marx, Economic and Philosophic Manuscripts of 1844, in The Marx-Engels Reader, ed. Robert C. Tucker (New York: $w$. W. Norton \& Company, 1972), 76.

${ }^{2}$ Here begins the expounding on the dogmatic Marx. Humanist ideas in Marx are presented first because they belong to the young Marx-his early period.

${ }^{3} \operatorname{Karl}$ Marx, "Letter to Annenkov," in Karl Marx: Selected Writings, ed. David McLellan (Oxford: Oxford University Press, 1977), 192; "Dialectical Materialism," in Essential Writings of Karl Marx, ed. David Caute (New York: The Macmillan Company, 1967), 41-50.

4Idem, "Defence of the Moselle Correspondent," in Karl Marx: Selected Writings, ed. David McLellan (Oxford: Oxford University Press, 1977), 24.

${ }^{5}$ Ibid. Emphasis supplied. 
same certainty as a chemist determines under which external conditions given substances will form a compound. . . . "l Creative praxis or the free human beings of the first version of Marx's thought are juxtaposed with an unfolding, deterministic historical law which defines individuals. Truth in history (knowledge) is no longer located in the free action and experience of men but in a material reality which shapes history and human beings. ${ }^{2}$ Although human beings still make history, they are nothing but marionettes in the hands of preexisting forces. Thus, in the works written in the post-1846 period ${ }^{3}$ Marx believed that socialism is possible only as a result of a clash of social classes and fought against utopian concepts which obscure the historical necessity of revolution. 4 Instead of the terms such as "praxis," "human essence," and "species being," one finds such terms as "labor theory of value," and "surplus value." 5

\section{IIbid., 25.}

${ }^{2}$ The Karl Marx Library, ed. Saul K. Padover, vol. 7, on History and People (New York: McGraw-Hill Company, 1971), 33-34; see also Mihajlo Markovic, From Affluence to Praxis (Ann Arbor: The University of Michigan Press, 1974), 59.

${ }^{3}$ The main works of Marx from the later period of his life (1846-1883) are: The German Ideology, Communist Manifesto, Capital, Grundrisse.

${ }^{4}$ See, for example, Marx, Grundrisse, 172-173, 323$325,539-542$.

5 Ibid. 
In the "Afterword to the Second Edition," Marx cited approvingly a passage from one of the reviews of Capital which summarizes his position on the relation of human freedom and deterministic laws of history:

Marx treats the social movement as a process of natural history, governed by laws not only independent of human will, consciousness and intelligence, but rather, on the contrary, determining that will, consciousness and intelligence. . . . If in the history of civilization the conscious element plays a part so subordinate, then it is self-evident that a critical inquiry whose subject-matter is civilization, can less than anything else, have for its basis any form, or any result of, consciousness. That is to say, that not the idea, but the material phenomenon alone can serve as its starting point. 1

Thus, in the first version of his understanding of reality. Marx speaks of the world which is shaped by free human consciousness, by creative human activity, that is, by praxis. The reality is primarily human reality because it "is man who fights the battles." In the second version of reality, Marx argues that it is the law of historical motion which, independently of human will, determines the action of human beings and thus shapes the future of humanity. ${ }^{2}$

The reason for this ambiguity stems from Marx's understanding of his task. Marx considered his work to be historical, scientific, and sociological, as opposed to philosophy which he regarded to be, at best, trivial and

\footnotetext{
IIdem, "From the Afterword to the Second German Edition," in The Marx-Engels Reader, ed. Robert $c$. Tucker (New York: W. W. Norton \& Company, 1972), 196.

${ }^{2}$ Gorman, Neo-Marxism, 6-14.
} 
61

possibly a hindrance to progressive action. ${ }^{1}$ Even in the works where Marx examined philosophical questions, 2 he did not systematically define a coherent philosophical system, and one can find nowhere a well-developed epistemology. 3 The key issues of Marx's philosophy such as mind's relationship to matter, whether the material world is passively reflected in the mind or is a product of human creativity, have been endlessly debated by Marx's followers. 4 Marx argued that the hotly debated topics by the bourgeois philosophers who were interested only in discussion and scholarship were already settled. 5 Thus, it was necessary to shift these controversies onto an economic, historical, and on political plane, where they must be

1McGovern, 17-19, 54, 259; Karl Marx, Preface to the Critique of Political Economy, in Karl Marx and Frederick Engels: Selected Works (New York: International Publishers, 1968), 184-185; Economic and Philosophic Manuscripts of 1844,76 .

${ }^{2}$ For instance, Economic and Philosophical Manuscripts of 1844, The German Ideology, Grundrisse, preface to the Critique of Political Economy (see Gorman, Neo-Marxism, 6).

${ }^{3}$ See David-Hillel Ruben, Marxism and Materialism (Atlantic Highlands, New Jersey: Humanities Press, 1977), 64; Gorman, Neo-Marxism: The Meanings of Modern Radicalism, 4.

${ }^{4}$ For further information, see Martin selige, The Marxist Conception of Ideology (London: Cambridge University Press, 1977) , 6-9; Gorman, Neo-Marxism: The Meanings of Modern Radicalism, 8-9; Kolakowski, Main Currents of Marxism, 1: 399-416.

${ }^{5}$ Karl Marx, Contribution to the Critique of Hegel's Philosophy of Right, in The Marx-Engels Reader, ed. Robert C. Tucker (New York: W. W. Norton \& Company, 1972), 16-17. 
measured by concrete concepts. "The philosophers have only interpreted the world, in various ways; the point, however, is to change it."I

Marx's Concept of Religion

\section{Different interpretations of the religious}

phenomenon in Marxism are due to the inconsistences in Marx's conceptualization of his metaphysical and epistemological concepts, as seen above, as well as to the fact that Marx's views on religion are, for the most part,

\footnotetext{
'Idem, "Theses on Feuerbach," in Karl Marx and Frederick Engels: Selected Works (New York: International Publishers, 1968), 30; for further information, see Gorman, Neo-Marxism, 78-85; Svetozar Stojanovic, Between Ideals and Reality (New York: Oxford University Press, 1973), 148; Richard Bernstain, Praxis and Action (Philadelphia: University of Pennsylvania Press, 1971), 62-63. It seems that Marx had tried to solve the problem by saying that human beings do affect history by only reinforcing its general course of development which is impersonal. Men make their history under the assumption that their "free" actions will always correspond to the laws of certain material conditions. However, the real solution, systematically defended answers, to this issue--whether human beings behave autonomously, as conscious actors, or are products of impersonal forces--remained unsolved in Marx's writings (Karl Marx, "Marx to $L$. Kugelmann in Hanover," in Karl Marx and Frederick Engels: Selected Works [New Yurk: International Publishers, 1968], 681; "On the Realm of Necessity and the Realm of Freedom," in The Marx-Engels Reader, ed. Robert $c$. Tucker [New York: W. W. Norton \& Company, 1972], 319-320; The Eighteenth Brumaire of Louis Bonaparte, in Karl Marx and Frederick Engels: Selected Works [New York: International Publishers, 1968], 97; "Alienation and Social Classes," in The Marx-Engels Reader, ed. Robert c. Tucker [New York: w. W. Norton \& Company, 1972], 105).
} 
only delivered en passant. ${ }^{1}$ In his early humanistic thought (1838-1846), he presented the most elaborated views on religion according to which religion is the illusion of alienated human beings. It is the projection into fantasy of a humanity that finds no fulfillment in this world. ${ }^{2}$ It is "the sigh of the afflicted creature, the soul of the heartless world, as it is also the spirit of spiritless conditions. It is the opium of the people." 3 Following Feuerbach, Marx states that "man makes religion, religion does not make man."4 "Man is the world of man" and nothing exists outside the reality of this world. 5

In his later dogmatic phase, Marx emphasized the element of religion as class ideology and reflection of the material order. ${ }^{6}$ Thus, the social principles of Christianity, for example, preach the necessity of a ruling and an oppressed class. The misery found in religion is the

\footnotetext{
${ }^{1}$ McLellan, Marxism and Religion, 31; see also Mihajlo Markovic, "Atheism Is Not Essential to Marxism; Critique of Religion Is," Journal of Ecumenical studies 22 (1985): 529 .

${ }^{2}$ McLellan, Marxism and Reliqion, 31. Marx writes: "Man who is in search for a supernatural being in the fantastic reality of heaven found only a reflection of himself" (The Karl Marx Library, ed. Saul K. Padover, vol. 5, on Religion [New York: McGraw-Hill Company, 1971], 35).

${ }^{3}$ Ibid., 35-36.

Ibid., 35 .

${ }^{5}$ Ibid.

${ }^{6}$ McLellan, Marxism and Religion, 31; see also Markovic, "Atheism Is Not Essential to Marxism," 528-534.
} 
way of expressing and at the same time protesting the misery of the economic conditions in society. ${ }^{1}$ In order to attain real happiness, an illusory happiness, that is, religion, must be abolished. 2 It also means that it is necessary to "give up a condition that requires illusion." 3 Therefore, "the criticism of heaven . . . is transformed into criticism of earth. 14

For Marx, religion was at the same time significant and insignificant. It was significant because it was a purely spiritual compensation for man's frustrations and it neutralized man's efforts to change oppressing material conditions. It was insignificant because Marx held that religion was only the secondary phenomenon, dependent on socio-economic conditions, and thus merited no independent criticism. Moreover, his colleagues, especially Feuerbach, had fully exposed the true nature of religion. 5

\footnotetext{
${ }_{1}$ Marx writes: "This state, this society produce religion, which is an inverted world consciousness because they are an inverted world. Religion is the general theory of that world, its encyclopedic compendium, its logic in popular form, its spiritual point d'honneur [point of honor], its enthusiasm, its moral sanction,. . . its general ground of consolation and justification. . . The struggle against religion is therefore indirectly the struggle against the world whose spiritual aroma is religion" (The Karl Marx Library, 5: 35).

2 Ibid., 36 .

${ }^{3}$ Ibid.

${ }^{4}$ Ibid.

${ }^{5}$ See McLellan, Marxism and Religion, 31; Marković, "Atheism Is Not Essential to Marxism," 528-534.
} 
65

There is, thus, a lack of coherent theoretical interest in religion in Marx, and his assertions about the disappearance of religion are highly speculative. ${ }^{1}$ Consequently, because of Marx's philosophical heterogeneity, Marxist philosophers are introducing their own philosophical presuppositions by being selective in the choice of his writings or by ignoring those elements that do not fit in it. 2 For dogmatic Marxists, Marx's materialism is essentially atheistic and thus hostile to religion. For the most humanistic Marxists, Marx was interested only in religion which nourishes and sustains class society. However, both dogmatic and humanistic Marxists, have developed a consistent interpretation of religion because they have taken from Marx's philosophy those elements that fit their own philosophical structure.

\section{Yugoslav Humanist Marxist Thought}

It is impossible to grasp fully the meaning and significance of ćimic's criticism and evaluation of the dogmatic Marxist concept of religion without taking a close look at the Yugoslav humanist Marxist thought which represents the immediate historical and ideological context for ćimić's work. The historical and political situation in post Second World War Yugoslavia, as well as the basic

\footnotetext{
${ }^{1}$ Ibid.

${ }^{2}$ Stojanović, Between Ideas and Reality, 148.
} 
contributions of Yugoslav humanist Marxists, such as the concept of praxis, alienation, and self-management, are described and analyzed only in so far as they pertain to the better understanding of the notion of religion among humanist Marxists in Yugoslavia.

The concepts of praxis, alienation; and selfmanagement in Yugoslav humanist Marxist thought are closely related to the concept of religion. The religious phenomenon itself is considered to be a form of alienation ${ }^{1}$ caused basically by the oppressive and unpredictable socio-economic conditions. ${ }^{2}$ For that reason, it is necessary to establish the self-managing society which makes possible for man to express his essential being, his creative and self-creative powers. Consequently, only in a society where man can be a being of praxis it is possible to expect the disappearance of religion as alienation. ${ }^{3}$

\footnotetext{
${ }^{1}$ some humanist Marxists argue that religion is not a form of alienation but a help for the completing of human personality. However, most of them consider religion a form of alienation (see Mladen Stankovic, "Covek i Religija," Praxis 7 [1970]: 650).

${ }^{2}$ Although there are also other sources of religiosity, the social-economic source is considered to be the cause of all other sources of alienation (see Vranicki, "Socialism and the Problem of Alienation," 482).

${ }^{3}$ Yugoslav humanist Marxists do not hold that religion per se will disappear but religion as an alienation will (ibid).
} 
Historico-political

Background

After the Second World War, Yugoslavia was the first eastern European country, besides Soviet Union, to be governed exclusively by the communist Party. ${ }^{1}$ In the period from 1944 to 1948 , the Communists in Yugoslavia were loyal followers of the Soviet Communists. Their Marxist theory and practice was modeled according to stalinism. 2 In 1948 the Yugoslav Communist Party, led by President Tito, broke away from the soviet orbit. Following this period was the time when President Tito felt very much on the defensive because he "was still trying to prove to all interested parties that he was an orthodox communist." 3 only after 1953, when it became evident that he had survived the pressures of the other communist governments and when it became necessary to show the rest of the world that Yugoslav Communism did differ from the Russian model, was the climate made for more intellectual freedom and creativity. From 1953 on President Tito and the party theoretician, Edvard Kardelj, approved a more open and flexible way for the

\footnotetext{
${ }^{1}$ Paul Mojzes, "Christian-Marxist Encounter in the Context of a Socialist Society," Journal of Ecumenical studies $9(1972): 5$.

2 Ibid.

${ }^{3}$ Ibid., 7; see also vladimir Dedier, Izqubljeni Boi J. V. Staljina (Lubljana: Delo, 1969), 357 .
} 
examination of a variety of problems in the popular press, books, and journal articles. 1

One of the important figures in the founding history of the humanistic Marxism in Yugoslavia was Milovan Djilas. In 1953 he became vice-president of Yugoslavia and president of its Federal Assembly. In that position he pioneered the efforts toward humanizing Yugoslav communism. He warned his Party that the process of bureaucratization was an internal contradiction of the revolution and argued for ideological toleration, diversity of free opinion, and democratization of the Yugoslav society. ${ }^{2}$ But with his criticism, he offended the men in power, was expelled from the party, and was repeatedly imprisoned. ${ }^{3}$

However, in the period from 1962 to 1972 , in a climate of relative freedom of expression, a group of independent Marxist thinkers set out to redefine the meaning and role of Marxist philosophy in the context of socialist society. ${ }^{4}$ After an initial intellectual fight with dogmatic Marxists, this group of humanistic Marxist thinkers

\section{Isee Mojzes, "Christian-Marxist Excounter in the} context of a Socialist Society," 9 . 1957), 173 .

${ }^{2}$ Milovan Djilas, The New Class (New York: Praeger,

Mojzes, "Christian-Marxist Dialogue in the Context of a Socialist Society," 8 .

${ }^{4}$ Ibid. , 130. 
(of which the Praxis circle ${ }^{1}$ was the most outspoken)

prevailed over the dogmatic approach and exercised a lasting influence on the intellectual and cultural atmosphere in Yugoslavia. ${ }^{2}$

Yugoslav humanist Marxists reject the extreme historical determinism as deficient for the understanding of man and society by citing Marx's own assessment of history's impotence to "fight battles" and to "possess great riches."3 They argue that even Marx is not consistent with himself when he writes as an extreme determinist because he also wrote in the eleventh thesis on Feuerbach that philosophers should not only interpret the world but change it. 4 The dogmatic Marxist concept of freedom as the awareness of necessity and the epistemological theory of reflection must be rejected and supplanted by the category of praxis, that is, free and creative ability of man to fashion himself and the world around him. ${ }^{5}$

The clue for the authentic interpretation of Marx's thought, according to humanists, is to be found in the early

\footnotetext{
Isee above, 7-8.

${ }^{2}$ Mojzes, Christian-Marxist Dialogue in Eastern Europe, 130 .

${ }^{3}$ Milan Kangrga, "Problem Otudjenja u Marksovu Djelu," in Humanizam i Socijalizam, ed. Branko Bošnjak and Rudi Supek (Zagreb: Naprijed, 1963), 102 .

4 Ibid.

${ }^{5}$ Mihajlo Marković, "Marxist Humanism and Ethics," Inquiry 6 (1963): 19.
} 
writings, especially in Economic and Philosophic Manuscripts

of 1844, on the Jewish ouestion, Contribution to the

Critique of Hegel's Philosophy of Right, Thesis on

Feuerbach, and The German Ideology. If one wants to

understand correctly Marx's philosophy, it is necessary to pay close attention to his early humanist inspiration which underlines all his works. 1

Marxism is basically a method of social criticism.

It is an incomplete, unfinished theory that contains unresolved questions. ${ }^{2}$ since Marx's thought is conceived as self-critical, it is the task of Marxist philosophers to evaluate and develop it in all directions. ${ }^{3}$ Marxism is "always critical social and political philosophy or it is nothing at all."4 It is inseparably linked to Marx's humanism and, thus, must consider human beings as the first, only, and the highest value, or it is not Marxism at all. 5

At this stage, the concept of praxis, alienation, and self-management must be considered because they are

\footnotetext{
IIbid., 19-24.

${ }^{2}$ See Gajo Petrovic, Marx in the Mid-Twentieth

Century (New York: Doubleday \& Company, 1967), 14 .

${ }^{3}$ Ibid.

${ }^{4}$ Svetozar stojanovic, "Contemporary Yugoslav Philosophy," Ethics 76 (1966): 298.

5 Milan Kangrga, "Program SKJ--Oslobadjanje Stvaralackih Snaga Socijalizma," in Humanizam i Socijalizam, ed. Branko Bošnjak and Rudi Supek (zagreb: Naprijed, 1963), 17; see also Vranicki, Historija Marksizma, 596.
} 
71

closely related to the concept of religion ${ }^{1}$ and also represent the main contribution of the Yugoslav humanist Marxist thought.

\section{Man as Praxis}

For the Yugoslav Marxist humanists, the category of praxis includes more than labor in the economic or industrial sense alone. Praxis is "the general structure of his [man's] relationship toward the world and toward himself," "a universal-creative and self-creative activity . - by which man transforms and creates his world and himself."2 Praxis consists of all activities which occur within spatial coordinates and which cannot be readily observed (for example, activities such as production and interpretation of statements and emotions, observation, the selection of values, and so on).$^{3}$

Praxis, as a general category, is a means by which man purposefully changes his natural surroundings, creates different conditions of social life and, by changing his environment, he creates himself. 4 Thus, praxis is a "conscious, goal oriented social activity in which man

\footnotetext{
${ }^{1}$ see above, 66-67.

${ }^{2}$ Petrovic, Marx in the Mid-Twentieth Century, 78.

${ }^{3}$ Mihajlo Marković, Humanizam i Dialektika (Belgrade: Prosveta, 1967), 130-133.

${ }^{4}$ Ibid.
} 
realizes the optimal potentialities of his being, and which is therefore an end in itself."1

The relationship between man and nature is characterized by both harmony and opposition. ${ }^{2}$ Man opposes nature in his effort to transform nature, to create a new nature by application of his free conscious activity. By making this new nature, he humanizes it, that is, he makes it correspond to his needs. ${ }^{3}$ This process of transcending nature and human limitations which are imposed by nature is what Marx calls history. ${ }^{4}$

Dogmatic Marxism considers man an economic animal, a concept which is "equally strange to the young and the old Marx."5 Man, for Marx, is not a "rational animal," "toolmaking animal," or "economic animal," but a being of praxis, that is, man's essential possibility and nature is in free creative activity. The question of freedom is also connected with man's essence, and both of them (man's freedom and essence) lie in praxis, that is, in man's free

\footnotetext{
${ }^{1}$ This quotation, as well as others which follow, was translated from Serbo-Croatian to English by the author of this study (ibid; see also From Affluence to Praxis, 46).

${ }^{2}$ Gajo Petrović, "Histoire et nature," Praxis International 1-2 (1966): 73-74.

${ }^{3}$ Ibid.

4 Ibid.

${ }^{5}$ Idem, Marx in the Mid-Twentieth Century, 23.
} 
creative activity. ${ }^{1}$ only if man is acting freely in the world is he able to fulfil Marx's imperative of changing it. Thus, Marx's humanism is conceived as superseding the traditional opposition between materialism and idealism since it constitutes their synthesis.2

Therefore, for Yugoslav Marxist humanists, man as praxis is the solution to the riddle of history; it is the key to the achievement of a more humane world in which the individual has become socialized and society has become individualized. 3 It is the way of liberation of all forms of alienation, including that of religion. Here lies the basic relation between the concept of religion and praxis.

Man and Alienation

Man as a being of praxis or "a potentially free, creative, social rational being, able to develop further his

\footnotetext{
${ }^{1}$ Petrovic writes: "As a being of praxis, man is a being of freedom. There is no freedom without man, and there is no humanity without freedom" (ibid., 118). Korac writes that it is "a simple matter to establish beyond dispute that from his youth to the very end of his life Marx thought and wrote about man as man, and labored to give the fullest possible definition to human essence" (Veljko Korac, "In Search of Human Society," in Socialist Humanism, ed. Eric Fromm [New York: Anchor Books, 1966], 5). Thus, revolution, for Yugoslav humanists, is not caused by the deterministic material laws but by the workers who subjectively and freely realize that capitalism destroys their essential humanity and alienates by transforming them into something that they are not.

${ }^{2}$ Petrovic, Marx in the Mid-Twentieth Century, 29.

${ }^{3}$ Supek, Sociologija i socijalizam, 327 .
} 
nature, to create new own senses, powers, abilities"I was conceived by Yugoslav Marxists as a concept counterposed against alienating social conditions ard forces. Thus, Marx's "humanistic theory of alienation and de-alienation" cannot be separated from his concept of man. 2

The problem of man's alienation is facing man in all societies (capitalist or socialist), and it is essential to Marx's thought on man and society. ${ }^{3}$ Alienation is a contradiction between "man's real 'nature,' or 'essence,' and his factual 'properties,' or 'existence'."4 It can be

${ }^{1}$ Mihajlo Markovic, "Basic Characteristics of Marxist Humanism," Praxis International 3-4 (1969): 614 .

${ }^{2}$ Petrovic, Marx in the Mid-Twentieth Century, 81 .

${ }^{3}$ See Vojin Milic, "Ideja Otudjenja i Savremena Sociologija," in Humanizam i Socijalizam, ed. Branko Bošnjak and Rudi Supek (zagreb: Naprijed, 1963), 112. Stojanovic states that the concepts of alienation and dealienation are "the most general synthetic-critical categories in Marx's humanistic theory." For Vranicki, alienation is the central problem of socialism since its very purpose of existence is to overcome alienation while, on the other hand, capitalism can only exist as estranged (Svetozar Stojanovic, "The Dialectics of Alienation and the Utopia of Dealienation," Praxis International 3-4 [1969]: 389).

${ }^{4}$ Petrovic, Marx in the Mid-Twentieth Century, 146; see also Predrag Vranicki, "Socialism and the Problem of Alienation," in Socialist Humanism, ed. Erich Fromm (Garden City: Doubleday \& Company, 1966), 304; Yugoslav Marxist humanists acknowledge that Marx and Engels have adopted or transformed some key concepts in the field of humanism (alienation included) from Hegel's speculative philosophy. For example: (1) Hegel's concept of objectification or externalization became, in Marx's terminology, estrangement or alienation, and reification; (2) Hegel's concept of unfolding Reason which passes through the process of objectification, estrangement, transcendence of estrangement through self-consciousness, and finally realizes as the Absolute Idea, Spirit, or History, became, in Feuerbach and 
applied only to man since only man can exist as something other than his essence and only he can change and become whole, real, and dealienated. 1 The phenomenon known as "homo duplex," that is, divided, estranged man, resulted from a dehumanized world of reified commodity relations of the capitalist wage-labor relations, that is alienation of work. ${ }^{2}$ since socialism eliminated some but not all causes of alienation, it still remains the central problem of socialist society. ${ }^{3}$ Although the task of socialism is to try to narrow the gap between man's essence and existence by creating better social conditions, it is also true that dealienation can never be absolute since its completion would leave no room for further progress. 4

Marx, a form of human alienation and the realization of the Spirit is no other than realization of man's essence through praxis; (3) Hegel's dialectical method of thesis-antithesissynthesis by which Reason unfolds in the process of universal history became, in Marx, according to Yugoslavs, a method of critical thought by which one is able to discover inner limitations and conflict of society; and (4) Hegel's concept of self-consciousness became, in Marx, the socialist consciousness of proletariat that is the most conscious of the social classes in history (see Petrovic, Marx in the Mid-Twentieth Century, 136; Andrija Kresic, "The Proletariat and Socialism in the Works of Marx and in the World Today," Praxis International 3-4 [1969]: 373; Mihajlo Markovic, "Critical Social Theory in Marx," Praxis International 3-4 [1970] : 286; Supek, 194).

${ }^{1}$ Kangrga, "Problem Otudjenja u Marksovu Djelu," 99.

${ }^{2}$ Vranicki, "Socialism and the Problem of Alienation," 482 .

${ }^{3}$ Ibid.

${ }^{4}$ See Stojanović, "The Dialectics of Alienation and the Utopia of Dealienation," 393. 
"Historically created human possibility" or man's essence will be realized by man himself acting creatively and freely (praxis).1 Through praxis it is necessary to humanize social man by liberating work from exploitation, by giving the power of making decisions to the people, and by humanizing sccial relationships. The end goal (viewed as a process of approximation), that is, the "new human society" will be characterized by the fact that the free development of each person would be the condition for the free development of all. 2

However, in spite of all these optimistic statements, Marx's concept of complete dealienation in the future society is today no longer tenable. ${ }^{3}$ All systems, socialist and capitalist, are confronted today with "superalienation" or "apocalyptic 'revolt of things' against its creator--the anthropological form of Final Judgement"-since man's own creations threaten his very existence on the planet. 4 The validity of Marx's view of society as the only source of man's alienation must be questioned because

${ }^{1}$ Ibid. , 147 .

${ }^{2}$ Korać, 8 .

${ }^{3}$ Stojanovic, "The Dialectics of Alienation and the Utopia of Dealienation," 397.

${ }^{4}$ Ibid. 
alienation reflects man's ambitions, aspirations, goals, and the various limitations of every day life. 1

Accordingly, Yugoslav Marxist humanists understand the complexity of the problem of alienation and are not ready to offer an easy answer to it. However, they argue that the only remedy for the religious form of alienation is to be found in the liberation of man, the reappropriation of the surplus value of his work, the humanization of production and market relations, and in the return of man to his real self (essential being) through praxis, which constitutes the basis of the concept of self-management. ${ }^{2}$

\section{Man and Self-Management}

The task of self-management is to overcome man's alienation. Political alienation of man is caused by the very existence of the state, bureaucracy. Economic alienation is caused by private or state ownership of the means of production. ${ }^{3}$ Both economic and political alienation may create an inclination in man toward the religious solutions for this-worldly problems. The precondition for any genuine dealienation of man and for

\footnotetext{
${ }^{1}$ see Milic, "Ideja Otudjenja i Savremena Sociologija," 138 .

${ }^{2}$ Kresic, "The Proletariat and socialism in the Works of Marx and in the World Today," 381.

${ }^{3}$ predrag Vranicki, "Teorijsko Zasnivanje Ideje o Samoupravljanju," Socijalizam 6 (1970): 729; Djordjevic, 9497.
} 
creation of a communist society that would consist of free association of immediate producers is the withering away of the state, bureaucracy, and politics since they represent the forces of oppression, the instruments of class rule, and exploitation. 1

In capitalism, the state stands for the tool in the hands of the ruling class through which general social interests are sacrificed to particular private interests, and it is that becomes the source of bureaucracy. ${ }^{2}$ However, even under socialism, the state can become the exploiter of the surplus value created by workers, it can become a "modern leviathan, an alienated power, basically independent of people." 3 Bureaucracy is responsible for the exploitation of the workers because it holds a monopoly on deciding the distribution of the surplus value.4 The only remedy for this evil is to make sure that immediate workers regulate production and dispose of the surplus value of their products, that is, self-management. 5

${ }^{1}$ Rudi supek, "Humanizam i Naturalizam," in Humanizam i Socijalizam, ed. Branko Bošnjak and Rudi supek (zagreb: Naprijed, 1963), 61.

2Idem, "Humanizam i Naturalizam," 61.

${ }^{3}$ Mihajlo Markovic, "Economism or the Humanization of Economics," Praxis International 3-4 (1969): 453.

${ }^{4}$ Radomir Lukie, Teorija DrZave i Prava (Belgrade: Savremena Administracija, 1964), 317.

5 Ibid. 
Yugoslav Marxist humanists argue that the search for the new democratic institutions of social self-government is synonymous with the search for new democratic and nonexploitive relations in the sphere of economic production. ${ }^{1}$ The socialization of the means of production, the selfmanagement and participation in decision making by the immediate producers via workers' councils, communes, assemblies at all levels (communal, republican, and federal) and the freedom in the organization of production and distribution of products represent the possible solution to the problem of man's alienation. ${ }^{2}$

However, the problem associated with the concept of self-management is that workers' councils, communes, and assemblies at all levels are representatives of the government rather than being the forms of direct participation of all the citizens. Thus, the problem of democracy will always remain open-ended and absolute democracy is an unattainable ideal. ${ }^{3}$

${ }^{1}$ Djordjevic, 94.

${ }^{2}$ See Vranicki, Istorija Marksizma, 573. In the sense of enterprises self-management means primarily the workers' councils in industry; "opstina" refers to the local government and expresses the concept of commune; the power structure implies the system of assemblies at all levels of government, communal, republican, and federal; the socialist Alliance of the Working People of Yugoslavia represents the broadest political form of people's self-government (see Mala Politicka Enciklopedija, 234-236.

${ }^{3}$ svetozar stojanovie, "Socijalisticka Demokratija i SKJ," in Marks i Savremenost, ed. Mihajlo Markovie (Belgrade: Institut Društvenih Nauka, 1964), 27. 
Therefore, self-management, for the Yugoslav humanist Marxists, is a particular form of praxis which allows the expression of man's essence. ${ }^{1}$ It is conceived as the emancipation and reinstatement of the whole man in all his dignity in a dealienated society of free men. Consequently, self-management society may be an important tool in the process of overcoming the religious alienation.

The Concept of Religion in the Yugoslav Humanist Marxist Thought

This section describes and analyzes the notion of religion as conceived by Yugoslav humanist Marxists. They have developed and defined their concept of religion as a reaction to the dogmatic Marxist view of religion. Thus, Yugoslav humanist Marxists argue that the dogmatic Marxist criticism of religion is limited because it is based on the general notions about religion without any scholarly research on the concrete forms of religiosity. ${ }^{2}$

Religion continues to live in spite of Marx's and Engels' prophecy of its disappearance. ${ }^{3}$ The disappearance of the social sources of religion reduce but do not destroy

${ }^{1}$ Ibid., 723 .

${ }^{2}$ See zdravko KuCinar, "Marksizam i kritiðki Pojam Religije," Kultura, nos. 13-14 (1971): 44; Marko Kerševan, "Savremeno Hrišcanstvo i Ideologija," Kultura 13-14 (1971): 78-79. ${ }^{3}$ Djuro Šušnjič, "Moc i Nemoć Nauke u Kritici Religije," Kultura 13-14 (1971): 59 . 
81

it. ${ }^{1}$ The human limitation of mortality finds its apparent solution in the religious hope of an afterlife. However, the tragic truth for humanity is that this life does not have any inherent meaning if all people would simply die. ${ }^{2}$ The reasonable solution to the riddle of life is to accept this existence heroically and to make it as meaningful as possible by accepting mortality and by living for others. ${ }^{3}$ Thus, although religion is an erroneous interpretation of life, it is still very attractive and understandable. 4

Religion changes uncertainty into certainty, mortality into immortality; it fulfills the need for the complete and absolute, makes virtue out of one of humanity's greatest defeats--death, and finds some solutions to humankind's daily problems and frustrations. 5 For some Yugoslav humanist Marxists, religion is not an alienation

\footnotetext{
${ }^{1}$ Bošnjak, Filozofija i Kršcanstvo: Racionalna Kritika Iracionalnog Shvaćanja, 362-386; see Mojzes, Christian-Marxist Dialogue in Eastern Europe, 132-133.

${ }^{2}$ Bošnjak, 362-386.

${ }^{3}$ Ibid.

${ }^{4}$ Branko Bošnjak is considered to be the first Yugoslav Marxist philosopher to show professional interest in religion. His contribution is that he was the first (in Yugoslavia) who openly stated that in Marxist philosophy the religious phenomenon is considered much simpler than it is in fact (see Mojzes, The Christian-Marxist Dialogue in Eastern Europe, 131, 231).

5šušnjic, 64 .
} 
but a specific form of social practice. ${ }^{1}$ It is basically determined by the reciprocal relationship between human beings and the experience of mystery and not by socialeconomic circumstances. This relationship has its locus in the religious practices (particularly liturgy) and the religious community (church). 2 Death and suffering are not the central cause of religion. ${ }^{3}$ Religion provides another world of freedom which is the opposite of the realities of this world. 4

The roots of religion are to be found in the human condition of incompleteness and partiality. 5 Marx was right when he said that religion is the soul of the soulless conditions, but it is also true that religion exists in the favorable economic conditions because in its essence religion is not deterministically caused by bad conditions

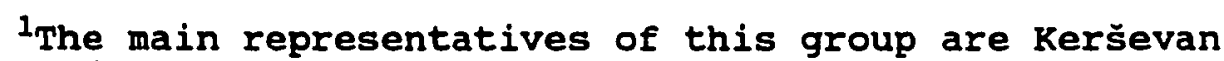
and Stankovic (see Marko Kerševan, "Teoretski Model za Proǔ̌avanje Religije kao specifične Prakse," Naše Teme 5 [1969]: 732-757; "Neka Sporna Pitanja Marksisticke Teorije Religije," Naše Teme 6 [1967]: 980-993; Stankovic, "Covek $i$ Religija," 648).

${ }^{2}$ See Kerševan, "Teoretski Model za Proucavanje Religije kao Specifične Prakse," 732-757.

3This view is contrary to Bošnjak's assertion that the main cause of religious belief is to be found in the human limitation of mortality and the hope of an afterlife (Bošnjak, Filozofija i Kršcanstvo, 362-386).

79.

${ }^{4}$ Kerševan, "Savremeno Hrišcanstvo i Ideologija," 78-

${ }^{5}$ Stankovic, "Covek i Religija," 650; see also

Mojzes, Christian-Marxist Dialoque in Eastern Europe, 233235. 
but by the general position of human beings in nature, their lack of wholeness, and their limitations which cannot be much improved. 1 Religion or the divine-human relation contributes to the creation of better humanity since God is the idealized human relation; he is a superhuman, nonalienated person; he represents perfection, competition, and the solution to the life's contradictions, he is somebody who is what humans would like to be. ${ }^{2}$ Consequently, religion may be an aid for the completing of oneself since through religion human beings receive what they do not have. ${ }^{3}$ The question that should be asked is not whether one is religious or not but whether one is humane or not, whether religion alienates or fulfills human beings, ties or liberates. If religion gives power to man to increase his participation in society, then religion can become a liberating force within socialism. 4

Christianity is to be considered as the greatest utopia in history. Thus, religion is an expression of human conviction in the possibility of a better and different existence from present suffering. ${ }^{5}$ Religion cares about

\footnotetext{
${ }^{1}$ Stanković, "Covek i Religija," 650 .

2 Ibid. , 652 .

${ }^{3}$ Ibid.

${ }^{4}$ Ibid. , 655 .

${ }^{5}$ Kuðinar, "Marksizam i Kritiðki Pojam Religije," 44; see also Mojzes, Christian-Marxist Dialoque in Eastern
} Europe, 235-236. 
the destiny of individual human beings, and because of that it is able to give meaning and purpose to human life. 1 since religion is a permanent a priori in human consciousness, it cannot be replaced by the increase of knowledge, and it will not wither away. ${ }^{2}$

science and religion are both closed systems of belief and practice since both attempt an interpretation of reality, orientation in reality that is riddled with uncertainty, transformation of reality to human needs, and an identification of the individual in relation to reality. ${ }^{3}$ This means that both systems have their own presuppositions, their own approaches to reality, their logic and methodology, their own criteria of truth and values, their own vision of life and death, and that both systems are on an equal level and neither must be denied its rationality. 4 The mistake of most critics of religion is that they reduce religion to some empirical facts and consider them to be the only reality, whereas religion has emotional, ritual, moral, experiential entities, that is, symbols which do not reflect empirical facts but which may

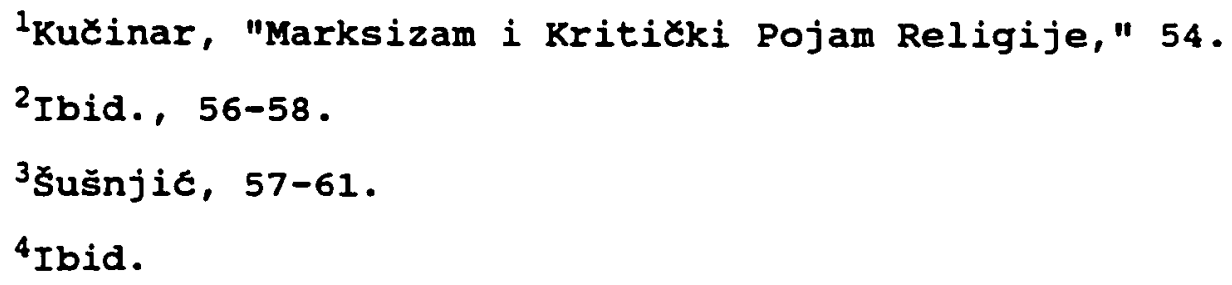


have the same influence on human behavior as do empirically verifiable facts. ${ }^{1}$

\section{Summary}

Although for Yugoslav humanist Marxists historical materialism is one of the basic assumptions, it seems that they are rather idealist Marxists in the sense that they are suspicious of the objective, deterministic moment of history's global movement, and at the same time, they strongly affirm essential structure of man's being which seems to be a transcendent, universal truth. ${ }^{2}$ Human essential nature--an idea that is taken from Hegel's idealism (self-consciousness or final realization of spirit) ${ }^{3}-$-is transformed into a transcendent truth immanent to humanity at every stage of human development. 4

On the basis of their assumption that man's consciousness is not a direct result of any social-economic conditions, Yugoslav Marxist humanists argue that religion will continue to exist in any social system. Religion is a result of manifold and complex interactions. It cannot be

${ }^{1}$ Ibid., 64.

${ }^{2}$ Gorman, Neo-Marxism, 124-126.

see above, 75,31 .

${ }^{4}$ Ibid. It must also be stated that for Yugoslav humanist Marxists, man's essence is defined as "historically created human possibility." Thus, it is always understood horizontally and never vertically (Petrovic, Marx in the Mid-Twentieth Century, 147). 
reduced to some empirical fact because it includes moral, emotional, and ritual elements. The roots of religion therefore are, to be found in the social-economic conditions and in the lack of wholeness of human nature as well. Marxists should cooperate with religious people because religious persons can contribute to the establishment of a more humane world. The establishment of a self-managing society in which man may be able to express his creativity, that is, to be a being of praxis, is the Marxist way of approaching the phenomenon of religious alienation.

\section{Summary and conclusion}

For dogmatic Marxists, human consciousness is the product of the inner movement of matter which determines the time and place of both thinking and revolution. For humanist Marxists, on the other hand, the authentic cognitive reflection is prior to revolutionary acts because the truth takes an abstract form which either unfolds historically or transcends history as an absolute historically realized by cognitive human beings. According to the dogmatic interpretation of Marx, there is little room for individual reflective initiative. According to humanist Marxists, the oppressed worker's consciousness through a subjective thought process produces critical thought and revolutionary action.

However, both Marxist interpretations, dogmatic and humanistic, assume that the truth exists as an a priori 
category. For humanist Marxists, truth is consciously recognized by active subjects, whereas, according to dogmatic Marxists, this truth impersonally determines the thoughts of subjects. 1 Both reject the difference between truth and falsity and accept the relativist concept of truth as a historical goal and knowledge as nothing else but the progress toward absolute truth. Both accept the idea of an ultimate reality. In the case of dogmatic Marxism, it is called matter; in the case of humanist Marxism, it is called history or moving totality of things.

The special contribution of Yugoslav humanist Marxists is their emphasis on the category of praxis, that is, an autonomous, undetermined, subjectively generated act that expresses the profound needs of man and is basically manifested in the creative work. Because of that, it is necessary to create a socialist ideology based on the workers' autonomy and self-government, conditions which would realize subjective freedom. Consequently, the society in which man would be able to express his essential being, that is, to be a being of praxis, represents the only way of liberation from all forms of alienation including a religious one.

The metaphysical and epistemological concepts of both dogmatic and humanist Marxists determined their understanding of superstructure, in general, and of

\footnotetext{
${ }^{1}$ See Gorman, Neo-Marxism, 157.
} 
88

religion, in particular. Their different philosophical presuppositions are the result of vague statements about metaphysics, epistemology, and religion found in the writings of Marx. Thus, for example, for the dogmatic Marxists, religion is nothing but expression of the dominant material relations. For the humanist Marxists, the relationship between the material base and cultural superstructure is more of an indirect nature since the economic cause creates only a disposition for acceptance of religious ideas. Consequently, religion is the result of the cooperation of the whole series of influences.

In sum, dogmatic Marxists argue that: (1) Marxist materialism is atheistic, hostile to religion, and must actively struggle against religion in order to abolish it; (2) religion appears only under the conditions of class society and is merely the mystification of natural and social relations, an escape from suffering into an illusory happiness; (3) the ruling classes use religion to hold exploited classes in passive subjection; (4) the mind of the religious people is warped in superstition and magic so that they become reactionary in the cultural, political, and social sense; and (5) religion will completely disappear in the future communist society when human are recognized as the highest being for humans.

Humanist Marxists hold that: (1) Marx's criticism of religion is oversimplified, and the result of the historical 
influences; (2) religion does not simply express the dominant economic conditions but attempts to cope with some perennial human problems; (3) religion is the result of the complex interactions of many different influences in man's existence; and (4) in itself, religion is neither good nor bad and in so far as it contributes to the class struggle on the progressive side, Marxists should cooperate with it.

In the last year or two, due to the radical changes taking place in the Soviet Union, dogmatic Marxism, in spite of the firm opposition from the conservative Marxist circles, is loosing ground. ${ }^{1}$ For instance, V. I. Garadzha, former director of the Communist Party's Institute of Scientific Atheism, questions the validity and effectiveness of many aspects of atheist work in the Soviet Union. He argues in favor of the rejection of "outmoded dogmas and decaying stereotypes" and for the re-examination of the dogmatic Marxist concept of religion. ${ }^{2}$ Religion, for Garadzha, taken as a whole, "is in no way hostile either to - . social system or to communist aspirations." 3 Thus, it seems that the humanistic Marxist view of religion is becoming more and more a generally accepted approach toward

\footnotetext{
${ }^{1}$ See V. I. Garadzha, "Atheist Work: A Reevaluation," Religion in Communist Lands 18 (1990): 72-79; Jane Ellis, "New Soviet Thinking on Religion," Religion in Communist Lands 17 (1989): 100-111.

${ }^{2}$ See Garadzaha, 76 .

${ }^{3}$ Ibid.
} 
90

religion among Marxists today. This makes this probe into humanist Marxists thought all the more relevant.

Now the following questions must be raised: How did

Esad ćimic criticize, evaluate, and reinterpret Marxist

dogmatic understanding of religion? What are his

contributions to humanist Marxism and where is his place in

the humanist-dogmatic Marxist controversy? 
CHAPTER III

ESAD ĆIMIĆ, THE MAN AND HIS THOUGHT

The purpose of this chapter is to describe and analyze those elements of Cimie's life and philosophy which define him as a man and as a philosopher of religion. It includes his biography, professional pilgrimage, starting point for his philosophy, shift in his philosophy, and ideological basis for his interpretation of Marx's concept of religion. These matters are of essential importance for the proper understanding of cimie's concept of religion and for discerning his approach to its reconceptualization.

\section{cimic's Early Life, Education, and Career}

Esad ćimić was born on June 3, 1931, in Mostar, the chief city of Hercegovina. He completed his basic education in Stoc and Mostar. ${ }^{1}$ From the Faculty of Arts and Human Sciences (Filozofski Fakultet [College of Philosophy]) at the University of Sarajevo, Cimic received his undergraduate degree with a major in philosophy and the doctoral degree in sociology of religion in 1964. His dissertation was the

${ }^{1}$ See Ivica Maštruko, ćimic, Esad, paper prepared for Hrvatski Bio-bibliografski Leksikon (Zagreb: Jugoslovenski Leksikografski Zavod, 1990), 1. 
first doctoral degree awarded in the field of sociology of religion in contemporary (post-war) Yugoslavia.1

From 1966 to 1976 Ćimic was a professor of

theoretical sociology at the University of Sarajevo.

However, in 1976, allegedly because of his moral and

political unfitness, Cimic lost his teaching position. 2

Following this he went to the University of Zadar where he

was professor and founder of the school of systematic

sociology (1976-1982).3 In 1982 ćimiC assumed a teaching

position at the Faculty of Arts and Human Sciences

(Filozofski Fakultet [College of Philosophy]) at the

University of Belgrade where he is currently professor of sociology of religion and sociology of ethics. 4

ćimić has been editor-in-chief of some journals:

Naši Dani [Our Days, 1953-1954], Odjek [Echo, 1965-1969], and Sociologija [Sociology, 1987-1989].5 He continues to be an outstanding initiator, ideologist, and participant

${ }^{1}$ For further information, see Gerald Shenk, Religion as Challenge for Humanist Science in the Work of Esad cimic and Diuro Šušniic, paper presented as part of the symposium "Studies in Humanist Sciences," in Dubrovnik, Yugoslavia, April 26, 1988, 3 .

${ }^{2}$ Kukot, review of politika kao sudbina, 28: 110.

${ }^{3}$ Maštruko, 1.

${ }^{4}$ Ibid.

${ }^{5}$ Ibid. 
(from the Marxist side) of the Christian-Marxist dialogue in Yugoslavia. 1

With his scientific contributions in the areas of philosophy and sociology of religion, ćimic has participated at numerous congresses, symposia, and seminars both nationally and internationally. ${ }^{2}$ He has led several important research projects in the fields of sociology and philosophy of religion, as well as participating in a number of research projects of broader sociological importance, either as the leader or a member of the research team. ${ }^{3}$

The literary corpus of Cimic's work comprises more than 120 items. A number of his works have been translated to Hungarian, French, Russian, Italian, and English. His articles and books have found an attentive audience in Yugoslavia and provoked a number of responses and discussions. 4

\footnotetext{
${ }^{1}$ For further information, see Muhic, review of Socijalističko Društvo i Religija, 8: 809-812; Mislav Kukoc, review of Drama Ateizacije, by Esad ćimic, in Nase Teme 30 (1985): 605-607; Mojzes, Christian-Marxist Dialoque in Eastern Europe, 194 .

${ }^{2}$ For instance, in Prague, Opatija, Portoroz, Zagreb, Belgrade, Ljubljana, Sarajevo, Dubrovnik, and Paris.

${ }^{3}$ Such as, Socialism and Religion, 1979; Young People Between Religion and Atheism, 1980; Marx and Marxists about Religion, 1987; Sociological Aspects of Priestly Vocation, 1974; and Atheism in Theory and Practice in Yugoslav Society, 1988 (see Maštruko, 1).

${ }^{4}$ For the list of Cimic's books, articles, and responses to his works, see above, 14-16.
} 
Some of the most influential contemporary Yugoslav Marxist philosophers (especially those who are interested in the Marxist understanding and criticism of religion) were students of cimic when he was teaching sociology of religion at the graduate level in the University of Zagreb. ${ }^{1}$ He has guided twenty-one candidates through their masters theses. ${ }^{2}$ ćimic has also been the major professor for seven doctoral dissertations which focused on the relation of Marxism and religion. ${ }^{3}$ Beginning with his doctoral dissertation ${ }^{4}$ and subsequent studies, cimic has become one of the founders of the study of modern philosophy and the sociology of religion in Yugoslavia. 5

\section{Cimie's professional pilgrimage}

ćimic's professional life has been closely related to the writing and publication of his major books. For that

\footnotetext{
${ }^{1}$ For example, Štefica Bahtijarevic, Marko Kerševan, Nikola Dugandzija. Nikola Skledar, Ivica Maštruko, and others (Esad Ćimie, Belgrade, letter to Radiša Antic, Berrien Springs, January 6, 1990).

${ }^{2}$ Among others, under his guidance graduated on the master level: Marko Kerševan, Nikola Skledar, Ivan Grubišić, and stipe Tadic (ibid).

${ }^{3}$ Cimic was the mentor for the doctoral dissertations to Zdenko Roter in Sarajevo, to Marko Kerševan, Nikola Skledar, and Ivica Maštruko in Ijubljana (ibid).

${ }^{4}$ See above, 14 .

${ }^{5}$ Maštruko, 3. Some other Marxist philosophers in Yugoslavia who also contributed in a special way to the development of the humanistic Marxist approach to religion are zdenko Roter, Marko Kerševan, Andrija Krešic, and Srdjan Vrcan (see Mojzes, Christian-Marxist Dialoque, 128-158).
} 
reason it seems appropriate to describe his professional pilgrimage by chronologically following the publication of his principal books and, at the same time, by briefly recounting the content of those works which have led to the major events of his professional life.

Ćimic's doctoral dissertation (1964) is a founding document for the modern Yugoslav approach to sociology of religion. 1 For this work ćimic received "The Award of the Sixth of April"2 from the city of sarajevo. The work is essentially empirical-descriptive and deals with different religious beliefs. The research was undertaken among the three main religious groups in his native Hercegovina; namely, orthodox, Catholic, and Moslem. His research explores the attitudes and participation of religious workers in the context of socialist self-management society. ${ }^{3}$

Ćimie's major and probably his most widely known work, Drama Ateizacije (The Drama of Atheization, 1971), was designed to speak "neither for nor against but about religion" from the perspective of Marx's "authentic

\footnotetext{
Ishenk, 3 .

${ }^{2}$ This is one of the most prestigious awards in the Republic of Bosna and Hercegovina established in the commemoration of the first German attack of Yugoslavia on 6 April 1941.

${ }^{3}$ See Ćimić, Socijalistið̌ko Društvo i Religija, 7-10.
} 
thought."1 Those whom ćimic attempted to reach in this book were the school teachers whom, he proposed, should liberate themselves from various misconceptions concerning the religious phenomenon. In Cimic's view, such misapprehensions were unacceptable from a humanistic Marxist point of view. ${ }^{2}$

ćimic himself admits in Drama Ateizacije that especially since he grew up in the context of constant presence of different religions, he counts himself as belonging to that group of people who were never indifferent toward religion. ${ }^{3}$ He recalls that as a young man he experienced an "internal drama" whenever he tried to overturn that "pleasant world" (Ćimic's religion) which, although according to all reasonable presuppositions is imaginary, remains real for the one who experiences it. 4 For cimic, to destroy that world also meant the destruction of bridges to one's dearest deceased relatives. Everything that departs from humans in irreversible fashion, such as dying, enters into a world of memories which sometimes

"Cimic uses the term Marx's "authentic thought" to designate his humanist interpretation of Marx which, in his view, represents the core of Marx's thought and stands in opposition to dogmatic interpretation of Marx (idem, Drama Ateizacije, 10).

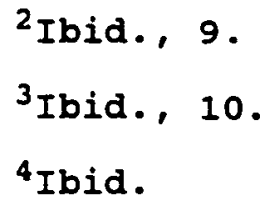


surround people with something imaginary or transcendental. ${ }^{1}$ For that reason, cimic maintains, many human rational arguments in regard to religion fail because of the difficulty of keeping a distance from that sphere. However, strength of thought and the power of the will can assist people to distance themselves somewhat even from that which represents an inseparable part of their internal being. ${ }^{2}$

cimie continues by arguing that it is necessary to devote attention, from the perspective of Marx's "authentic thought," to the sociological aspect of the religious phenomenon. In his view, this helps pedagogues to gain insight into relevant characteristics of religion. At the same time, the sociological aspect of religion will demonstrate that any attempt to give a particular pedagogical stance toward religion which does not take into consideration the facts coming from the broader social context is methodologically unacceptable. ${ }^{3}$ He expresses his hope that both religious and atheistic readers, after reading his book, may become less satisfied, that is, more critical with their own religion or atheism, and more

\footnotetext{
"'́imic uses the term "transcendental" to designate everything that is beyond empirical. However, he always remains on the horizontal level (ibid.; see below, 266-267).

2 Ćimic, Drama Ateizacije, 10.

${ }^{3}$ Ibid. , 9.
} 
motivated to develop their own critical consciousness. 1 The humanist approach toward Marxism, in general, and religion, in particular, expressed in his prama Ateizacije found an approving audience among the general public, but definite opposition among dogmatic Marxists. ćimic wrote his next major book, Uvod u Marksizam (Introduction to Marxism, 1975), during a period of political turbulence which disrupted his own professional career. As with his previous writings, this work carried forward Cimiés critique in reference to Marxism. After being submitted anonymously and selected by a jury for publication, even while ćimic was falling under official sanctions in Sarajevo, it became a definitive text book for basic courses in Marxism. ${ }^{2}$

\section{Covjek na Raskršcu (Human Being at the Crossroad,} 1975), by cimic, was banned, withdrawn from the circulation, and destroyed while he lost his teaching position at the University of Sarajevo in 1975. ćimic gives an account of this book and its background in his later book politika kao Sudbina (Politics as Destiny, 1982). However, the reception, by the general public, of the narrative of covjek

\footnotetext{
IIbid. It is important to notice that this criticism of both religion and Marxism had been undertaken by cimic at the time when the prevailing concept of religion among the members of the Yugoslav communist Party was the dogmatic one.

$$
{ }^{2} \text { see Shenk, } 6 .
$$
}


na Raskršcu (1975) was so enthusiastic that it came to be used in the form of drama as a theater piece. 1

In that work, cimic takes events and people with whom he himself had collaborated as the subjects of his investigation. ${ }^{2}$ Although he used a subjective approach (and thus risked subjectivism), he argued that this might help to break into the hidden mechanisms of human behavior and activity. ${ }^{3}$ yet, his method is complemented by an objective approach based on abundant documentary material which gives the work the seal of factualism and authenticity. 4

With a short but very instructive historical survey of the concept of politics, ćimic brings into focus its double character. He conceives of politics as manipulative, alienating play "with the people." Such, he considers, is characteristic of the totalitarian, repressive, and classdominated society which he sets in opposition to the Marxist humanistic concept of politics as the sphere of human creativity, that is, "play of the people." 5

\footnotetext{
IIbid.

${ }^{2}$ See Ćimić, Politika kao Sudbina, 9-11.

${ }^{3}$ Ibid.

${ }^{4}$ See Kukot, review of Politika kao Sudbina, by Esad ćimić, 110 .

5ćimic, Politika kao sudbina, 1.
} 
100

cimic, as the main actor of this political drama, describes the chronology of his own suffering which was the consequence of the conflict with a provincial kind of Marxist dogmatism. 1 In a very convincing way he shows the nonsense and absurdity of an inquisitorial kind of persecution which is executed under the mask of humanism, brotherhood, and unity. ${ }^{2}$

The conflict begun in 1975 when cimic, then editorin-chief of the journal odjek, attempted to determine the causes of the exodus of a number of prominent cultural workers from Sarajevo. His inquiry brought the animosity of the local establishment. The opposition, which continued to intensify in the following years, lasted a whole decade. 3

The first step in the process of political persecution experienced by cimic was initiated by the bureaucrats in Sarajevo who removed him from his position as of the editor-in-chief of odjek. Then, his expulsion from the membership of the communist Party followed as a consequence of an interview shown on television in Sarajevo. Next, his book, Coviek na Raskršcu, was banned and destroyed on the basis that the author had previously been elected to a position of regular professor at the University of

\footnotetext{
I'Ibid., 1-33.

${ }^{2}$ Ibid.

${ }^{3}$ Ibid.
} 
Sarajevo. 1 The circle was closed when ćimic was expelled from his job. 2

In his Dogma i Sloboda (Dogma and Freedom, 1985), Ćimie argues that Marx's thought should be understood as a theoretical summary of the historical experience of humanity. It stands in opposition to any form of dogmatic Marxism which elevates the fragments of reality to the level of totality which then serves as an absolute norm. ${ }^{3}$

In his most recent book, Ateizam kao povijesni Humanizam (Atheism as Historical Humanism, 1988), Ćimić brings the theme of humanism into direct relationship with the religious question. This work plays down the significance of the dogmatic Marxist insistence on atheism

\footnotetext{
lobserve that during the court process against his book, cimic himself did not have the right to defend his own work because, according to the laws of Republic of Bosna and Hercegovina, the publisher is responsible for the content of his publications. The representative of the publishing house defended his publication with such a "zeal" that the whole process lasted only three minutes (ibid., 129). Another ugly moment connected with the court case of cimic is the fact that Dr. Muhamed Filipovic, a well-known and recognized scientist in the sarajevo area, professor at the University of Sarajevo, representative of the republic of Bosna and Hercegovina at the Encyclopedia of Yugoslavia, signed in a very short period of time two totally opposite appraisals of the book Covjek na Raskršcu. First, he praised the book and then under the pressure of bureaucrats, he had condemned it because of his own political career (see Nikola Miloševic, "Covek Koji je Glasno Razmišljao," in Politika kao Sudbina [Belgrade: "Srbija," 1982], 220).

${ }^{2}$ For further information, see cimic, Politika kao Sudbina, $129,20-23,99,30$.

${ }^{3}$ Idem, Dogma i sloboda, 21.
} 
as an important goal in and of itself.1 Rather, cimic insists on a larger program aimed at the radical humanization of society and on commitment to those changes which empower ordinary human beings to take charge of their own lives. ${ }^{2}$ For cimic, more crucial than the endless rational debate about the existence or the non-existence of supernatural beings is the promoting of creative critical consciousness and decisive action. ${ }^{3}$

Therefore, during his professional pilgrimage, ćimić seems to have arrived at the conclusion that not only is there an ecclesiastical "clericalism" but also a party or atheistic "clericalism."4 Bureaucracy represents a type of unconscious atheistic clericalism. 5 consequently, it is certain that the ten-year period during which cimic faced political persecution has influenced and, in many ways, determined his approach toward the religious phenomenon.

\footnotetext{
${ }^{1}$ one must, however, point out that cimic did not completely distance himself from the enlightenmentrationalistic approach toward religion which characterizes dogmatic Marxism (see idem, Dogma i sloboda, 102; see below, 250-257).

2̌́imie, Dogma i sloboda, 102.

3Idem, Ateizam kao Povijesni Humanizam, 61-68.

4Idem, Covjek na Raskršcu, 103-106, 109, 146-147. Clericalism is a policy that attempts to maintain or augment the temporal political power of a church or religious hierarchy. Here clericalism is used in the sense of an attempt by a group of people to rule over others (see Mojzes, Christian-Marxist Dialogue in Eastern Europe, 152).

${ }^{5}$ See Ćimic, Čovjek na Raskršcu, 147.
} 
The starting Point of cimie's Philosophy

The basic concern that undergirds the whole philosophical system of cimic is the idea of man free from all alienation, be it class, nationalist, religious or any other. Man is alienated and in need of true freedom. 1

In Cimic's philosophy, the concept of a free man is discussed from the perspective of the relation of individual and society and is defined in reaction to the dogmatic Marxist view according to which human beings are determined by the social-economic structure of society. Thus, cimic argues that the supreme norm of dogmatic Marxism is political pragmatism. ${ }^{2}$ The very essence of stalinism-which is the practical example of dogmatic Marxism--is

\footnotetext{
${ }^{1}$ See, for example, idem, Drama Ateizacije, 197-203; Dogma i Sloboda, 119-161; Ateizam kao Poviiesni Humanizam, 61-83.

2Cimic uses the term "political pragmatism" to condemn the fact that in most socialist countries individual freedom of men is sacrificed in the name of the economic development of society as a whole and in the name of the belief in the future communist society which will bring the happiness and satisfaction of all human needs (see cimic's letter, 1990). Markovic expresses a similar idea to ćimić, when he warns against the ideological system of "economism," which, for him, is a set of assumptions about social life depicting man as an economic being motivated entirely by selfish and consumption-oriented interests. He also states that "economism" visualizes the maximization of income as the highest goal of socialist society and argues that "the most important thing for socialism.. . is complete liberation of economic laws and the undisturbed development of commodity-money relations" (Markovic, "Economism or the Humanization of Economics," 452).
} 
contained in the elevation of the partial concept of reality to the level of general theoretical principle. 1

Marx's humanistic vision of the world, according to cimie, is opposed to the dogmatic Marxist determinism of human beings by the social-economic structure of society. In order to express the concept of humanity liberated from all kinds of determinism and conflicts, cimic uses the terms "socialized humanity" or "humanized society."2 These concepts express an attempt to establish, explicitly or implicitly, a relational identity between society and the individual without negating either individuality or community. ${ }^{3}$

I"Partial concept of reality" designates, for cimić, primarily the economic factor (that is, the development of mode of production as the economic base of society) which, according to dogmatic Marxist philosophy, has the deterministic significance for social development. For cimie, in general terms, the economic factor is only one element in the totality of reality and thus, should not have the totally deterministic significance for social development. However, ćimic also, and in spite of the clear statements that material structure should not have the deterministic significance for the social development, emphasizes the importance of material base at the expense of other factors within the totality of reality (Ćimic's letter, 1990; see also below, 247-250).

${ }^{2}$ see Ćimić's letter, 1990.

${ }^{3}$ Cimic here discusses the general relationship between society and an individual. However, the real issue at stake which lies behind it is determinism of individual human beings by the material structure of society as affirmed by dogmatic Marxists in the countries where communism is an official ideology (see skledar and Kukoc, Variation of Historical Materialism in Yugoslav Sociology of Religion, 2; see also cimic's letter, 1990). Stojanović, in different terms, expresses the same idea when he argues against dogmatic Marxist concept of the "necessity of 
For instance, in the sentence "Socrates is man," man as individual is included in the category of men. Man carries in himself the characteristics that classify him in the category of men. Universality, that is, those characteristics which are the result of the socialhistorical experience of humanity, should be absorbed as personal nature in an individual. 1 Thus, Cimic's ideal is "socialized people" who have "soaked in and interiorized humanness. " 2

To illustrate with his view of ethics, ćimic suggests that rather than being imposed by society, that is from outside, ethical norms should be an intimate way of behavior. Humanist Marxist ethical behavior implies that the individual and society are to become so interwoven that

developing a strong material base as the absolute precondition of socialism" at the expense of individual freedom of people. For him, those who justify the free action of economic laws at the expense of individual freedom and even the development of social inequalities do not differ in substance from appeals of stalinism to the citizenry to abandon immediate material satisfaction in the interest of the future communist society, because both ideologically justify alienation in this world with the promise of salvation in the next (stojanovic, Between Ideals and Reality, 131-133, 217).

${ }^{1}$ In other terms, ćimic suggests that man as an individual stands in the dialectical relationship with the social (see Ćimic's letter, 1990).

${ }^{2}$ When cimic discusses the relationship between the society as a whole and an individual, he implicitly rejects the dogmatic Marxist concept of social being (material structure) which impersonally determines human mind. For him, therefore, social being (material structure) is in a dialectical interrelationship with the individual (ibid; see also idem, Uvod u Marksizam, 72). 
the more society is molded in a humane way the more it is hard to delineate between the two. ${ }^{1}$ In addition, belonging to one's nationality is not of primary importance, but belonging to one's individual feelings through which one belongs to all.2 In the field of economy, social property is social only inasmuch as it involves the individual. If it does not involve the individual, the property does not belong to the society but to the group. ${ }^{3}$ Another instance, aesthetics and religion should be understood as a search for the establishment of harmony between the individual and society and not as a simple reflection of matter. 4

Dogmatic Marxism approaches all these phenomena (that is, ethics, aesthetics, religion) from the position of the theory of reflection which is totally opposite to Marx's understanding of man as a being of praxis, that is, an active, creative, and self-creating being. 5 Thus, the main

'Ibid. See also Ćimic's letter, 1990.

2'cimic is, in a special way, concerned with the question of nationalism because he grew up in an area troubled by nationalistic tensions.

3́imić's letter, 1990.

${ }^{4}$ Ibid.

${ }^{5}$ The theory of reflection is based on the premises that, first, material structure has supremacy over the consciousness (superstructure). It means that ideas (for example, ideas of science, philosophy, law, ethics, religion, etc.) are the direct product of the substructure. second, it claims that the economic factor (that is, development of the productional forces as the economic base of society) is of totally deterministic significance for total social development (Skledar and Kukoc, Variation of 
implication of ćimic's starting point for his

reconceptualization of the dogmatic Marxist criticism of religion is the rejection of the causal determinism of human beings by the substructure as well as the coercive methods toward religion and the need to create social conditions in which man will be able to creatively express himself. Freedom of human beings, for cimic, is the way of liberation from religious alienation. 1

Ćimie's humanist interpretation of Marx's work as social philosophy, in his own words, may be designated as an anthropological personalism which has sprung up from a humanistic nucleus and socially transforming "charge" (naboi) contained in Marx. ${ }^{2}$ he also acknowledges his great indebtness to the philosophy of existentialism ${ }^{3}$ and personalism. ${ }^{4}$ saint Augustine's Confessions and Blaise

Historical Materialism in Yugoslav Sociology of Religion, 2 ; ćimić's letter, 1990, 2; see above, 31-34, 37-38).

1'ćimié, "Religion and Church in Socialism," 83.

2'cimie's letter, 1990.

3The term "existentialism" includes a variety of philosophies. It is associated with philosophers such as Søren Kierkegaard, Karl Jaspers, Martin Heidegger, Albert Camus, and Jean-Paul Sartre. Existentialism may be described as an attempt to philosophize from the standpoint of the actor rather from that of the detached spectator (see James Richmond, "Existentialism," The Westminster Dictionary of Christian Theology [1983], 201-204).

${ }^{4}$ Personalism is a philosophical standpoint which takes as its starting point the human being. It finds in human beings the main key to central metaphysical problems. Although philosophers $M$. Buber and $N$. Berdyaev have sometimes been described as "personalists," the term is best 
Pascal's Thoughts have provided and still provide inspiration for ćimie. ${ }^{1}$

\section{Shift in Ćimie's Philosophy}

It is possible to detect evolution in cimic's thought as he enriched and developed some of his early philosophical concepts. ${ }^{2}$ Besides adding new elements to his initial teachings, he has made a radical shift in, at least, two areas--the shift from a dogmatic to a humanist Marxist position. ${ }^{3}$ The two areas are: (1) the sources of religion, and (2) the disappearance of religion.

At first, in praksa i Religija (1960), cimic emphasizes the fact that the source of religious beliefs is

reserved for the Boston school of philosophical personalism and its main representatives, B. P. Bowne and E. S. Brightman (see James Richmond, The Westminster Dictionary of Christian Theology [1983], 443-444).

'Ćimic's letter, 1990.

${ }^{2}$ For example, in praksa i Religija, cimić states that religion produces in man the feeling of passivity, the feeling of pessimism, and the feeling of absence of real humanism. However, in Ateizam kao povijesni Humanizam, although religion may produce in man the feeling of passivity, pessimism, and absence of real humanism, it may also inspire man in his struggle against social injustices. or, cimic openly acknowledges, Marx's assertion of the disappearance of religion in the socialist society was wrong since the empirical data coming from history demonstrates the opposite (see Ćimic, Praksa i Religija, 10-11; Ateizam kao Povijesni Humanizam, 63; Dogma i Sloboda, 169 ; letter, 1990).

${ }^{3}$ 'imic denies that he has made any radical shift (see Ćimić's letter, 1989). 
to be found in oppressive social and economic conditions. 1 Class-dominated society with the alienating social conditions produces alienated and perverted human consciousness, that is religion. ${ }^{2}$ Private property, which is the product of economic alienation, is the source of all forms of alienation, including the religious one. ${ }^{3}$

In his doctoral dissertation, the social-economic sources of religion are still maintained, but there is a change of emphasis. Ćimié recognizes here, much more than in his master thesis (Praksa i Reliqija), the multidimensional character of religion. Psychological and cognitive sources of religion play a much greater and more important role. 4 It seems that his previous one-source theory is replaced by multi-source theory. For example, cimic writes: "Religion is born partially from the economic structure of socialism, on the basis of man's dependence." 5 Religion should not be considered to be a remainder of the

\footnotetext{
IIdem, Praksa i Religija, 2.

2Ibid., 3.
}

${ }^{3}$ Ibid., 19. It is also true that already here, cimic mentions two other sources of religion, namely, cognitive (which refers to the desire of man to break through his limited knowledge) and psychological (which refers to man's existential fear). But, in both cases, he clearly emphasizes that even these two sources (cognitive and psychological) have their common source in social and economic conditions (ibid., 4-6).

${ }^{4}$ see idem, socijalistiðko Društvo i Religija, 34-48.

${ }^{5}$ Ibid., 45. Emphasis supplied. 
pre-socialist types of society, but rather a product of yetnot-overcome sources of alienation. ${ }^{1}$

Ćimic also adds that while "social-economic powers. - strongly affect the maintenance of religion," they are not the only source." "Every personal drama carries the possibility of going back to the bosom of dependence, because man during that period of time often looks for the irrational solutions." 3

In his Drama Ateizacije (1971), Cimic writes that religion must be approached as a universal phenomenon ${ }^{4}$ and that it is impossible to point to only one or two basic sources of religion. 5 He now sees religion as a very complex and many-sided phenomenon which behaves in ambivalent ways. 6 In addition to its already mentioned psychological, cognitive, and social aspects, Ćimie adds

IIbid.

2Ibid., 46. Emphasis supplied.

${ }^{3}$ Ibid. , 47 .

${ }^{4}$ cimic writes that religion is not universal truth (in the biblical, that is, transcendental-vertical sense), but, as with all human visions, religion is the product of man's mental structure. Religion ought to be considered as relatively universal historical and psychological fact since it is not limited to this or that period in the development of society. However, cimic always remains on the horizontal level, that is, he excludes supernatural from his philosophical system (see idem, Dogma i sloboda, 130-132).

${ }^{5}$ Idem, Drama Ateizacije, 199.

6Ibid., 198. 
ritual and moral features of religion. ${ }^{1}$ Religion is to be situated in the drama of human life, beginning with birth and stretching on to biological death. 2

In his latest book, ćimic writes about the anthropopsychological structure of religion. ${ }^{3}$ He acknowledges that "it is undisputable that some forms of the religious phenomenon are not to be included in social-historical praxis."4 cimic argues that the basis for the establishment of religion is given "from herself, by herself, and in her framework."5 The roots ${ }^{6}$ of religion, however, remain to be socially-economically conditioned. When the roots of religion disappear, only the political (class) ${ }^{7}$ character of religion will vanish because the

${ }^{1}$ See ibid., 29-50. However, in spite of his efforts to denounce the decisive significance of economic factor for total social development, ćimic's position remains ambivalent (see below, 247-250).

2ćimic, Drama Ateizacije, 197.

Idem, Ateizam kao Povijesni Humanizam, 75.

"Cimic uses the term "social-historical praxis" to designate the social-economic factors, that is, the material substructure of society as the source of religion (ibid).

5 The expression "from herself, by herself, and in her framework" refers in Cimic's philosophy to the anthropopsychological structure of human beings as the source of religion (ibid).

6Ibid., 67-75. For the detailed discussion on cimic's concept of the "roots" and "basis" of religion, see below, 208-209.

${ }^{7}$ It is religion which helps the capitalists to maintain their privileged positions in society. 
anthropo-psychological structure of religion will continue to resist the influences of society. 1

Now one must consider the second area of shift in cimic's philosophy closely connected with his concept of the sources of religion, i.e., his concept of the disappearance of religion. At first cimic insists on the importance of scientific analysis ${ }^{2}$ and the change of socio-economic conditions in order to be able "to create a new world and a life in which we will be able to exist without religion and to think in a qualitatively different manner."3 He also writes that "the basis for the abolition of religion and obtaining of spiritual freedom is to be found in socialeconomic conditions." 4 consequently, he implies that the change of socio-economic conditions would automatically cause the disappearance of religion.

Then ćimic adopts a more complex approach towards the religious phenomenon. He states that it is necessary to abolish all sncial and economic conditions which enslave man in order that he may be able to find his "total being" and,

\footnotetext{
1'́imic, Ateizam kao Povijesni Humanizam, 67-75.

${ }^{2}$ This term reminds us of the dogmatic Marxist assertion that the universe is run by means of immutable laws of matter, which must first be understood and then harnessed by complying with them (see Mojzes, Mojzes Addendum, 1).

3'́imie, Praksa i Religija, 16. Emphasis supplied.

4 "Social conditions" here designate primarily economic conditions (ibid., 18).
} 
at the same time, to rid himself of all illusions (including religion). 1 Nevertheless, he adds that self-managing society in which man more and more abolishes his social dependencies only contributes to the transformation of religion. In other words, Cimic expects that people will abandon traditional religion but not religiosity in general. ${ }^{2}$

In the next step, cimic deals with religion as an anthropo-psychological fact. He observed that this aspect of religion can often successfully resist socio-economic changes because it is related to the ontological structure of man's nature. 3 This represents the "basis" of religion. However, the "roots" of religion are to be found in socioeconomic conditions. If its roots are eliminated, it is hard to imagine, according to ćimic, that religion would be able to exist for very long and, if it continued to exist, it would necessarily be something quite different. 4

Finally, in 1985, cimic dares to claim (the Communist Party was still very strong at that time), on the basis of sociological research both inside and outside of Yugoslavia, that religion was not disappearing, but just

${ }^{1}$ Idem, Socijalisticko Društvo i Religija, 44-45.

2 Ibid., 48 .

3 Idem, Drama Ateizacije, 202.

4 Ibid. 
114

transforming its form. ${ }^{1}$ Those Marxist philosophers who were optimistic about the disappearance of religion were wrong. Religion needs to be considered as a live, historical force which this world would have to take into serious account in the future. ${ }^{2}$

Therefore, the analysis of the shift in cimic's philosophy from the dogmatic to humanist Marxist perspective shows that he did not from the very beginning of his career embrace fully humanist ideas. This explains the existence of some remains of dogmatic Marxist elements in ćimic's philosophy of religion in spite of his claim that his reconceptualization is a radical break with dogmatism.

\section{Cimie's Theoretical Basis}

In addition to ćimic's background, professional pilgrimage, starting point, and shift in his philosophy, his ideological basis--that is, his concepts of metaphysics, epistemology, his interpretation of the origins and development of Marx's thought on the religious question, his contribution to the problem of "earlier" and "later" Marx viewed from the perspective of religion, his understanding of the relationship between science and religion, and his methodological presuppositions--must be counted among the traits which serve as the foundation for his

\footnotetext{
${ }^{1}$ Idem, Dogma i sloboda, 126.

2 Ibid.
} 
reconceptualization of the dogmatic Marxist concept of religion and which define him as a philosopher and sociologist of religion.

Metaphysics 1

Cimic basically embraces the humanist Marxist concept of metaphysics according to which reality is identified with an all-inclusive totality that properly relates subjective and objective moments, that is, substructure and superstructure. ${ }^{2}$ Parts within the totality of reality must be understood in relation to the whole, because when isolated they are only an empty abstraction. ${ }^{3}$

ćimic has attempted to establish a type of antidogmatic historical materialism that takes into consideration the full complexity of a peculiar relation between material and ideational. 4 For him, the material

${ }^{1}$ since Cimic's concept of metaphysics and epistemology is almost identical with the humanistic Marxist view discussed above, it is not presented here in detail.

2́cimic, Uvod u Marksizam, 50.

${ }^{3}$ Ibid. , 68-72; idem, Coviek na Raskršću, 23-24.

${ }^{4}$ Although man, in cimic's view, is influenced by social-economic conditions, he also influences and changes these conditions (ibid). Vranicki expresses similar idea when he writes: "We see man as par excellence a being of practice, a being who freely and consciously transforms his own life. . . . Man exists and develops only by transforming his natural and social reality and... in this way he transforms himself also" (Predrag Vranicki, "On the concept of Practice," Praxis 1 [1965]: 42). 
and the ideational are in a dialectical relationship where only, "in the last resort," material plays a decisive role. ${ }^{1}$ In other words, the basis of the being of society is economy and, consequently, the socio-economic factors are essential since all other elements within the reality are mediated by them. ${ }^{2}$ Thus, it seems that the term "essential" (bitni), in ćimic's philcsophy of religion, designates primarily the dominating mediative and influential and not causally-deterministic feature of socioeconomic sources in relation to other sources of religion. ${ }^{3}$ Cosequently, ćimic differs from the dogmatic Marxists in that he rejects the total causal, deterministic relation between the material basis and ideational superstructure. In addition, he contends that there is no rigid dichotomy between base and superstructure. Economic structure, integrated with all other social relations, forms a movable totality that cannot be strictly divided from superstructure. 4

\footnotetext{
${ }^{1}$ Idem, Uvod u Marksizam, 69-72.

2Idem, Ateizam kao Povijesni humanizam, 63. In my view, cimic's concept of the relationship between material and ideational is inconsistent because he attempts to safeguard the freedom of human beings, their subjectivity and, at the same time, to affirm the essential nature of the economic factors (for further discussion on this point, see below, 247-250).

3ćimic, Uvod u Marksizam, 69-72.

${ }^{4}$ Idem, Uvod u Marksizam, 50. However, Ćimic also states that the social-economic sources are essential for the creation of human ideas and that all other sources
} 
117

It is because the ideational and material, in Cimic's reconceptualized notion of metaphysics, represent two poles of reality which are not in the causal but dialectical interrelationship that religion is not a simple product of the material base which would disappear with the elimination of the social-economic injustices. 1 Religious ideas must be understood as the result of the complex dialectical interactions within the totality.

\section{Epistemology}

Ćimic asserts that the source of knowledge is not to be found not only in the social-economic base because, in his view, this represents only one aspect of the dialectical process of the totality of reality. ${ }^{2}$ substructure and human consciousness do not correspond to each other ${ }^{3}$ since knowledge is the result of human subjectivity ${ }^{4}$ as well as

spring up from the material structure of society (for further discission on this inconsistence see below, 247250).

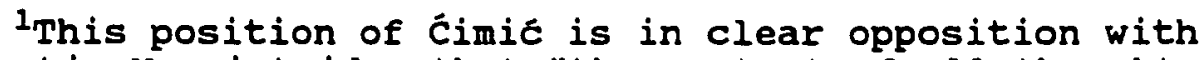
the dogmatic Marxist idea that "the content of all thought and knowledge must derive from sensus experience," and that law, politics, art, and religion are nothing but the "fantastic reflection" of the material structure of society (see Engels, Dialectics in Nature, 229, 313). 247-250.

2́cimić, Uvod u Marksizam, 71.

${ }^{3}$ For further discission on this point, see below,

${ }^{4}$ Cimic here comes very close to the existential concept of epistemology according to which man's knowledge of being must begin with his own personal being, since man himself is the only element in being which possesses self- 
of different influences of other elements within the totality of reality. ${ }^{1}$ The criterion for true knowledge is praxis. What contributes to the success of praxis is true and valuable; what hinders this success is false and evil. ${ }^{2}$ The ideas of philosophy, art, morality, science, law, and religion are influenced by the material sphere of production. However, these ideas may differ and may influence the productional relations (relations in consummation of goods, relations in exchange of goods, relations in distribution of goods, and in relations toward the means for production). ${ }^{3}$ Thus, because of the dialectical interrelations within the totality of reality, it is impossible to determine in an exact way where substructure stops and superstructure begins. 4

understanding and hence understanding of being in general (Richmond, "Existentialism," 202).

1'́cimie, Uvod u Marksizam, 71, 132.

${ }^{2}$ See idem, Drama Ateizacije, 46.

${ }^{3}$ Idem, Uvod u Marksizam, 113. Ćimic's idea that subjective human knowledge can differ and can influence the material base of society stands in opposition to the following statement of Engels' which expresses the identity of human thought and matter due to the causal relationship: "The fact that our subjective thought and the objective world are subject to the same laws, and that consequently too in the final analysis they cannot be in contradiction to one another in their results, but must coincide, governs absolutely our whole theoretical thought" (Engels, Dialectics in Nature, 313).

$$
{ }^{4} \text { Ćimic, Covjek na Raskršcu, 23-24. }
$$


Because knowledge involves also human subjectivity and may differ from the existing social-economic relation, some aspects of cimic's reconceptualized notion of religion must be understood as independent from the social-economic base of society. 1 In addition, cimic's assertion that there is no causal connection between substructure and human consciousness implies that religious ideas should be approached carefully as complex, multi-dimensional phenomenon.

cimic's View of the origins and Development of Marx's Thought on the Question of Religion

\section{Cimic begins his discussion on the origins and} development of Marx's thought on religion ${ }^{2}$ by describing

\footnotetext{
'Pavićevie, like ćimié, refuses to consider religion as a simple expression of oppressive social-economic conditions. For him, the source of religion is primarily emotional. Religious feeling is a very special, autonomous feeling which cannot be identified with some other feelings, such as aesthetic. Yet, it is not an extra-physical or nonsocial phenomenon. According to ćimic, in opposition to Pavicevic, religious feeling can be identified with the aesthetic feeling (see Pavićevic, Sociologija Religije, 25).

2 The question of finding the philosophy to which Marx's philosophy "corresponds," from which it derives, or which it implies has been extensively debated (the question of religion included). For example, Karl Kautsky connected it with Darwinism. Max Adler and Eduard Bernstein have found a correspondence between Marxism and Kantian philosophy. Plekhanov, while aware of Marx's Hegelian origin, preferred to ally Marxism with Feuerbach's materialism. Henri de Man attempted to combine Marxism with Freudianism following the presupposition that there is similarity between the two. György Lukacs, on the other hand, insisted that Marx belonged in the Hegelian tradition (see McInnes, "Marxist Philosophy," 173-174).
} 
the discussions in the Young Hegelian Doctoral Club which gathered around Bruno Bauer. ${ }^{1}$ Marx, at the end of the 1830s, as a student of law in Bonn and Berlin, was an active member of the Young Hegelian student movement. The main issues debated in the Doctoral Club were Hegel's philosophy, liberalism, and Christianity. One could feel among the members of this society a strong hatred toward the royal government, the church, and the bourgeois. 2

Christianity was one of the most debated topics in the dialogues and polemics of the Doctoral Club. However, in cimie's view, the main enemy in the eyes of the students in Berlin, lying even behind their criticism of Christianity, was the reactionary character of the Prussian state. Christianity was the sum of ideas by which one could

\footnotetext{
${ }^{1}$ Bruno Bauer, the young Hegelian, was on the theological faculty of Bonn University. Both Protestant and Catholic theologians considered him to be godless. Among other things, his critical theology questioned the miracles of Jesus and the authority of the Bible. He not only rejected the historicity of the Gospels but argued that the story was the conscious invention of a single author. Bauer hoped that Marx, upon taking his doctorate, would join him as a teacher of philosophy at Bonn University. That never took place because the government and other conservative theologians organized opposition to the radicals. Other important members of the Doctoral Club who influenced Marx's thought were Arnold Ruge (1803-1880), Moses Hess (18121875), and Ferdinand Lasalle (1825-1864) (see Marx, The Karl Marx Library, Saul K. Padover, vol. 5, on Religion, xvii).

${ }^{2}$ See Ćimić, Ateizam kao Povijesni Humanizam, 26.
} 
explain and justify the injustice and underdevelopment of Prussia. ${ }^{1}$

Hence, members of the Doctoral club began to criticize Christianity and its leading spiritual figures, thereby hoping that their critique would result in positive social and economic changes. Bauer, for instance, had attempted to prove that Hegel's philosophy was essentially atheistic. Following Bauer, Marx also attempted to show that Hegel was anti-Christian. ${ }^{2}$ It is during that period (1842-1844) that Marx became increasingly the "enemy" of religion. ${ }^{3}$

The journalistic activities of Marx (he was the editor of Rheinische zeitung) contributed further to the development of his interest in economics and social problems. Marx came to the conclusion that the religious conception of higher (supernatural) powers is nothing more than a transformed notion of this-worldly, economic, and social powers. 4 During this period, Marx also determined the differences between Young Hegelians and Feuerbach. The former concentrated all their powers on the formulation of ideas by which Christianity could be eliminated because of its reactionary character in the name of reason and

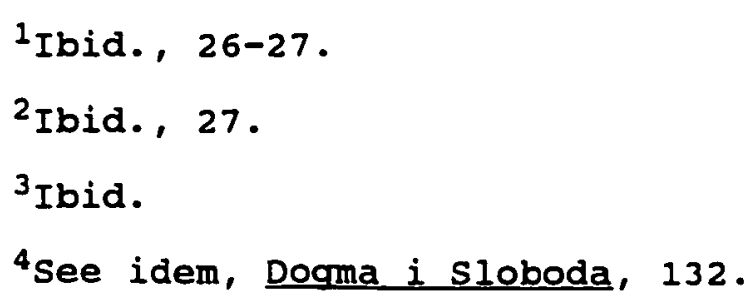


progress. For Feuerbach, religion is a phenomenon which reveals the truth about people. Marx embraced Feuerbach's idea that the divine being is, in reality, the human being. God is a human conception and not an absolute reality. 1

Nonetheless, Marx did not retain Feuerbach's position that man is alone. ${ }^{2}$ For Marx, man is a historical being who exists always in relation to what is and to what is not, but could be. This relationship is called history which represents the unique process in which man, on the one side, and everything else that exists, on the other, participates. Thus, man is the mediator between what is by itself (nature) and what is in the historical world. He is in relation to everything that is. ${ }^{3}$ Man's ability to relate himself to the totality of reality and also toward the foundation of his being or essence ${ }^{4}$ is what makes him human since animals do not have this ability. 5

\footnotetext{
IIdem, Ateizam kao Povijesni Humanizam, 27.

2That "man is alone" in Feuerbach's philosophy means, for ćimie, that Feuerbach interpreted man as the only reality without taking into consideration his relation to the external world. This is a kind of contemplative materialism which does not understand the importance of practical activity (ibid., 28).

${ }^{3}$ Ibid.

${ }^{4}$ 'imic alludes here to Marx's concept of man's "essential nature" or "genetic being." Man's essential nature is an ideal; something that is not, but could be. Thus, man, in distinction to animals, is able to relate to this ideal.

${ }^{5}$ Ćimić, Âteizam kao Povijesni Humanizam, 28.
} 
In order to clarify further the development of the concept of religion and its relation to the concept of metaphysics in Marx, Ċimic mentions the views of some other philosophers. 1 For instance, according to Plato, the world of ideas is the real, while the empirical world is apparent and unreal. The world of ideas is the principle of activity, the mover of history, and the transformer of the empirical world. Hegel held that the Mind is the foundational and ultimate reality. The Young Hegelians maintained that all that was necessary to bring about change in the world and to move it to become ideal was to point out the right ideas. Feuerbach remained on the level of philosophy and was not concerned with politics. 2

Marx, on the other hand, wanted to transform the empirical into the rational. Against the abstract mind Marx opposed the mind of real history. Ideas and truth might become real material forces, but this pertains only those ideas and truth which have become the theoretical resume of

\footnotetext{
${ }^{1}$ Here Ćimic contrasts Marx's view of metaphysics with the metaphysics of Plato, Hegel, Young Hegelians, and Feuerbach in order to be able to present his interpretation of the origins and development of Marx's thought on the religious question. As noted above the concept, of metaphysics (in the case of dogmatic Marxists, humanist Marxists, and ćimić himself) is closely related to and determines the concept of religion (see above, 26, 117).

2̌́imic, Ateizam kao Povijesni Humanizam, 30.
} 
the historical experience of humanity. ${ }^{1}$ The whole of

Marx's intellectual effort was directed toward the abolition of the difference between what is worthy (vrijednosno) and what is real $^{2}$ and the transformation of the worthy or intelligent (umno) into the real.

The origins and development of Marx's thought on the question of religion plays an important role in cimic's reconceptualization of the dogmatic Marxist criticism of religion. In ćimié's view, it should serve as one of the clues for determining the extent and nature of Marx's understanding of religion. ${ }^{3}$

Thus, by rejecting Hegel's assertion that only mind is real and by arguing that only history or this-worldly is real, Marx attempted to demonstrate that religion has its essential source in the unjust conditions of the capitalist society. However, Marx also was influenced by Hegel's idealism. This is evident in his concept of man's

${ }^{1}$ Contrary to the Young Hegelians, Marx held that a change of ideas will not change the world in its essential aspects because ideas themselves are changeable since the world is changeable (ibid.)

${ }^{2}$ According to Hegel, only mind is real and everything else, namely, all roality is an expression of the Absolute, who is God. For Marx, only empirical, that is, historical is real. Hence, Marx, according to ćimić, attempted to change historical into rational which is not supernatural but represents the theoretical resume of the historical experience of humanity (see P. H. de Vries, "Hegel, Georg Wilhelm Friedrich," Evangelical Dictionary of Theology [1984], 502-503).

$$
\text { 3́cimić, Ateizam kao Povijesni Humanizam, 26-33. }
$$


"essential being"I which is the result of the historical experience of humanity. Accordingly, Marx argued that although religion has its source in the oppressive economic conditions, religion also expresses the desire of man to transcend himself and to attempt to reach "essentiality."2 Marx rejected those aspects of Feuerbach's philosophy in which he dealt with man as the only reality without taking into consideration man's relation to everything that exists outside of him. However, Marx embraced Feuerbach's idea that religion is a phenomenon which reveals truth about man himself and that divine being is nothing but the expression of man's wishes and desires. ${ }^{3}$ Under the influence of Hegel and Feuerbach but also on the basis on his personal research, Marx argued that the very existence of religion means the existence of insufficiency. 4 The source of this insufficiency must be looked for primarily in social-economic circumstances. Religion is not the basis but only the "epiphenomenon" of the oppressive social-economic conditions. Religious phenomenon must be explained and understood from the insufficiency of the world and society in which men live. Therefore, dogmatic Marxist approaches toward religion

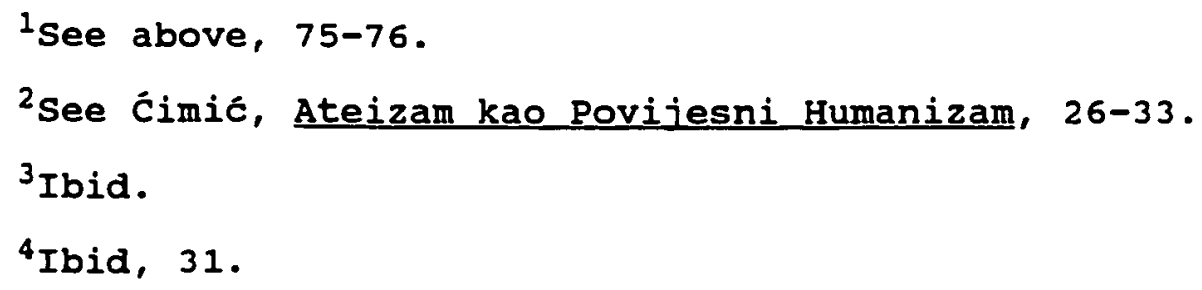


(enlightenment-rationalistic, spontaneous-economic, and administrative) are invalid because in order to overcome religious insufficiency (alienation), men must first overcome their socio-economic insufficiency. 1

\section{Cimic's View of the "Early"} and "Later" Marx

In his discussion of the problem of discrepancies and contradictions between the philosophy of the "early" and "later" Marx," ćimic uses the concept of religion as an example of his interpretation of the issue of whether there is continuity or discontinuity between Marx's Early Writings ${ }^{3}$ and capital. 4 If there are some differences,

${ }^{1}$ As mentioned above, cimic does not hold that socioeconomic conditions are the only source of religion. However, he does argue that the roots of religion are to be found in social-economic conditions (for further information, see above, 111).

2It is presumed that Marx in his works written in the early part of his life (1839-1846) adhered to the concept of human beings as free and creative. In his later works (especially Capital), Marx apparently replaced the concept of creative and free man with the notion of man determined by preexisting material laws. For that reason it seems that there is an opposition between "early" and "later" Marx. ćimic attempts to solve this problem by using the concept of religion as an example of continuity (for further information, see Gorman, Neo-Marxism, 8-11; see also above, 56-64).

${ }^{3}$ The most important early writings of Marx are: Contribution to the critique of Hegel's Philosophy of Right (1843), On the Jewish Ouestion (1843), Economic and Philosophic Manuscripts of 1844, The Holy Family (1845), Thesis on Feuerbach (1845), and The German Ideology (19451946). 
then, in cimić's view, it is necessary to determine their nature. Do the "early" and "later" Marx represent totally different points of view or are they complementary? In other words, are they functioning within the same concept of humanism which applies to the field of philosophy ("early" Marx) and later in the field of history ("later" Marx) ?1

In order to be able to answer these questions and to explain his own position, ćimic first addresses a few general remarks towards Marx's understanding of religion. Faced with the structure of theological thought, Marx found the key to decipher it in the domain of immanencetranscendence, that is, this-worldly versus other-worldly. ${ }^{2}$ This-worldly designates the sphere in which man can act and bring about changes through his historical praxis. Otherworldly designates the sphere in which man can neither act nor bring about change. Rather, man can merely have some ideas about it by the way of speculative philosophy. Thus, having ideas of the other-worldly is equal to theory without practice. ${ }^{3}$ The theory-praxis relation is of great

${ }^{4}$ Ćimić, Ateizam kao Povijesni Humanizam, 34. Those writings of Marx that are usually considered to be different from those written in the period from 1839-1846 are: Communist Manifesto (1848); The Eighteenth Brumaire of Luis Bonaparte (1851-1852); Theories of surplus Values (18621863); and Capital, vol. 1 (1867), vol. 2 (1885), and vol. 3 (1894).

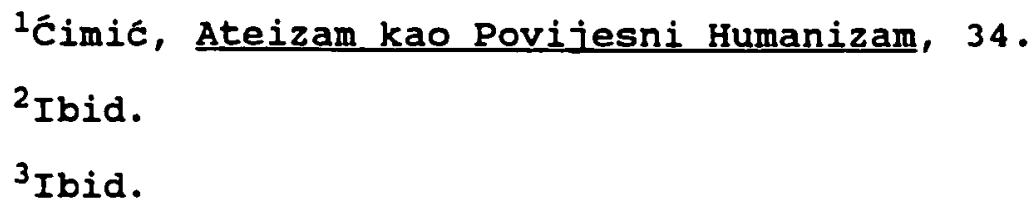


importance since practice as creative and self-creative act is the criterion of truth. Therein lies the reason for Marx asking: Should a theory be developed which cannot be realized? ${ }^{1}$

Marx thought that the cause for the existence of the other-worldly theory is man's powerlessness and confusion. since the this-worldly lacks the possibility for the realization of man as a being of praxis, man has no other solution but to express his revolt against the misery of the this-worldly reality by thinking of justice as something other-worldly. ${ }^{2}$ In this way man puts the control of justice into the hands of the other-worldly powers. Hence, religion appears to be a critique of crude and brutal reality and, at the same time, the expression of total powerlessness in the face of this reality. ${ }^{3}$

Thus, having established the relation between the concept of religion and social-economic conditions in Marx, cimic suggests that the criticism of religion, for young Marx, represented a theoretical critical model for the criticism of crude reality of society, in general, which, because of its insufficiencies, inspires man to look for solutions in the other-worldly. ${ }^{4}$ However, in his capital,

\footnotetext{
${ }^{1}$ Ibid.

${ }^{2}$ Ibid., 34-35.

${ }^{3}$ Ibid., 35 .

${ }^{4}$ Ibid.
} 
religion no longer represents the critical model for the theoretical criticism of society, in general, but represents only one historico-materialistic analysis and criticism of society, namely, capitalistic society. ${ }^{1}$

In addition, ćimic asserts the continuity between "early" and "later" Marx by stating that the "early" and "later" Marx share many common points which are present in the writings from both periods. Such points are, for instance, the relation between the theory and practice and the relation between the illusion and reality. ${ }^{2}$

If the "early" and the "later" Marx have common points, then, is there any contradiction? cimic holds that there is no discontinuity and that the only difference is on the level of approach rather the conceptual contradiction. While in his critique of religion the "early" Marx remains on the philosophical-anthropological level, the "later" Marx, without abandoning his humanistic, theoretical concepts, locates his critique of religion in the historicosociological level. For that reason, Marx had already concluded in 1844 that the theoretical criticism of religion

\footnotetext{
${ }^{1}$ For Marx, in cimic's view, the function of religion in feudal and capitalistic society was different in so far as the socio-economic relations within these societies differed. One cannot deal with religion as an established form which exists outside space and time. Religion behaves dialectically because ideology it is always in search of its personal identity from above which escapes the methods of science (ibid., 36).

${ }^{2}$ Ibid.
} 
is a completed task. The "later" Marx analyzes the core of capitalistic society which is permeated with religious presuppositions. He analyzes the real conditions of human Iife. ${ }^{1}$ Therefore, on the basis of analysis of the concept of religion as an example, it is possible to conclude, in cimic's view, that the main concern of Marx, in the early as well as later part of life, is humanity liberated from all alienation. 2

The fact that there is no discontinuity between "early" and "later" Marx, means, for Ćimie's reconceptualization of dogmatic Marxist philosophy, that the concept of praxis, that is, free and creative human beings, is present not only in the writings of "early" Marx but dominates all his works. This contradicts the dogmatic Marxist concept of causal determinism of superstructure (which includes human consciousness, ideas) by the socioeconomic substructure, and implies, first, that religion, as one of the forms of man's creativity, cannot be approached as the simple result of the socio-economic conditions, but as a multi-dimensional and relatively autonomous phenomenon. Second, freedom is the only means which can be used in the

\section{IIbid.}

2Ibid. Gorman argues, contrary to cimic, that there is discontinuity between "early" and "later" Marx. He states that in Capital Marx replaced the concept of praxis from the early period of his life by a determinism according to which objective material reality impersonally shapes history and its human subjects (see Gorman, Neo-Marxism, 10). 
process of human beings' liberation from religious illusions. 1

cimic's View of the Relation

of Science and Religion

Science, in cimic's view, is a human activity which deals with the area of the empirical; that is, the historical, social, natural, and psychological. ${ }^{2}$ Religion, on the other hand, deals with the supra-historical, otherworldly, and metaphysical. ${ }^{3}$ Consequently, it follows that in relationship between religion and science there is no essential interfering. 4

The eventual conflict between science and religion happens when distinct areas of competence interfere with each other. When theology attempts to be competent in the empirical field, or when science, using its own means and methods, attempts to deny the religious a-rational relation to the metaphysical as well as its mystic contents, then they are operating outside of their own competence. 5

\footnotetext{
${ }^{1}$ see Ćimic, Drama Ateizacije, 210.

${ }^{2}$ Idem, Dogma i Sloboda, 127.

"Cimic uses the term "metaphysical" as synonymous with "slipra-empirical" (idem, Drama Ateizacije, 204).

${ }^{4}$ Ibid.

5'cimic writes: "The conflict [between science and religion] is unavoidable when the scientist overlooks not only the historical but also the methodological boundaries of science and gives to the so imagined science philosophical status, but without philosophical presuppositions and methods. It always happens when science
} 
Science and religion are essentially disparate forms of spiritual activity which do not meet in the essentials and, thus, cannot deny each other. ${ }^{1}$

Knowing that theology is losing to science in the empirical area, some theologians give up their intention to oppose science and, instead, try to incorporate scientific results into their theological systems. ${ }^{2}$ However, this is

tries, regardless of the importance of its results, to make them universal and absolute. . . The conflict is unavoidable when a theologian identifies the theological with the scientific and when he takes away the metaphysical substance from religion by extending the sphere of its influence to empirical" (ibid., 204; see also idem, Dogma i Sloboda, 130-131).

1Ibid., 131. Šušnjić basically agrees with ćimić when he states that science and religion do not contradict each other, but compliment each other since they are relatively independent systems. The world in which men live today is increasingly insecure and fills human beings with anxiety. Science cannot solve this problem. It is religion which accomplishes daily adaptations of human frustrations, finding some solutions for them (see Šuśnjic, "Moc i Nemoć Nauke u Kritici Religije," 59-69).

${ }^{2}$ cimic writes that some contemporary theologians, being aware of the conflict between the empirical (scientific) and religious (metaphysical) realms, begin to approach the whole problem differently by recognizing the boundaries of science and religion. He states: "The category of methodological atheism [science] is of great importance because it helps scientists to realize the boundaries of their activity and at the same time makes it possible for the theologians to understand how the nonscientific [philosophical] foundations of science are protected from an a priori theological symbol. The behavior of the scientists as if God does not exist, regardless of the scientists' religious or atheistic orientation, is the formula which makes possible the right scientific approach and does not jeopardize his intellectual or moral integrity. Therefore, the hypothesis of God's existence is superfluous in spite of the fact that by scientific methods it can be neither confirmed or refuted" (Ćimic, Drama Ateizacije, 204205). 
a wrong method since the religious area exceeds the possibilities of science. Science can neither deny nor verify religion. ${ }^{I}$

cimic adds that the metaphysical area into which scientific knowledge cannot enter is not only the domain of religious transcendence but also the domain of philosophy with its attempts to resolve a secret of the primordial and the eschatological. ${ }^{2}$ For that reason it pertains to philosophy and not to science to enter into dialogue with theology. ${ }^{3}$

However, ćimić also contends that philosophy and theology have different approaches. Traditional theology claims to have an "almighty key" to provide answers to human questions related to the origin and purpose of everything. Philosophy, on the other hand, is aware of its own suppositional status and remains tentative on the open horizon in which every answer to a question is threatened by the possibility of a new question. 4

\footnotetext{
${ }^{1}$ Ibid., 205.

${ }^{2}$ See idem, Dogma i Sloboda, 133-135.

${ }^{3}$ Ibid.

${ }^{4}$ Ibid., 134. Branko Bošnjak adopts a much more dogmatic view concerning the relation between philosophy and theology. For him, Marxism is considered a rational criticism of an irrational worldview. He identifies philosophy (Marxism is the philosophy) with the former, and religion and theology with the latter (Bošnjak, 169-178).
} 
cimic's assertion that science and religion are different forms of spiritual activities implies that the claim for an absolute contradiction between science and religion is wrong. It also suggests that scientific knowledge, contrary to the teachings of dogmatic Marxists, will never be able to wipe out religious belief.

\section{Ćimie's Methodological Presuppositions}

Marx is considered, by ćimic, to be primarily a social philosopher ${ }^{1}$ since he points out those things in society which cause human estrangement as well as to the necessity of getting rid of them in order to create a more humane world. The philosophical theories of reality are not sufficient because philosophers may make revolutions only in the field of philosophy. Marx is interested in a radical change in which the other-worldly would be replaced with the this-worldly. ${ }^{2}$ he examined the religious phenomenon in the historical and thought context of the capitalist, classdominated society, and was interested in religion only in so far as it represents the expression (or the "ornament" in ćimić's terms) of that society. Marx was not interested in religion per se but in religion which maintains the

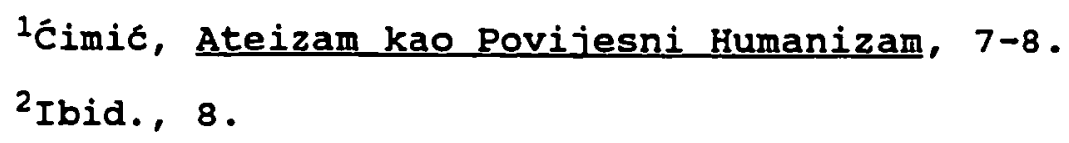


existence of class society. Here, for ćimic, is the limit of Marx's critique of religion. ${ }^{1}$

Ćimic also maintains that Marx should be approached in a Marxist way; that is, one should critically investigate the theoretical and historical relevance of the various elements of his theory. ${ }^{2}$ This approach means that a Marxist evaluation of Marx's critique of religion must take into consideration all that was changed inside the religious phenomenon as well as that which has remained the same since the time of Marx. Although one should not neglect Marx's direct statements about religion, it must be noted that such statements are much less important (and in many cases even of marginal importance) in comparison with the totality of his opus which must serve as a methodological criterion. ${ }^{3}$

\section{Summary}

Cimic is one of the founders of the modern Yugoslav school of sociology of religion. He was born in a geographic area (Bosna and Hercegovina) which had long been a place of religious contention and intolerance. In this sociological and geographical context, he became a foremost leader in attempts at reconciliation. ćimic himself was the object of persecution by the Communist Party bureaucrats for

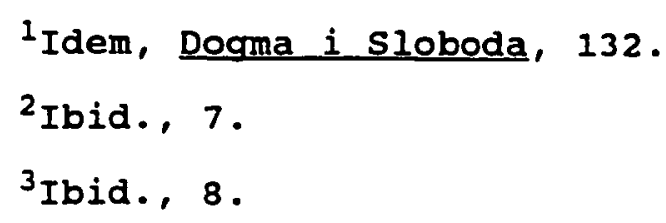


almost ten years. It seems certain that the sufferings he experienced during that period strongly influenced his philosophical concepts.

The starting point and the main concern of cimic's philosophy is the concept of free man, liberated from all conflicts and alienation. Free man is one who succeeds in reconciling the opposition between the individual and society.

cimic uses the category of "totality" in order to demonstrate that there is a close and complex relation between partial elements of reality within the totality of reality and not causal relation (between base and superstructure) as dogmatic Marxists assert. Consequently, for him, the concept of "socialized humanity" means that man, as a partial element of reality, is not determined by the socio-economic structure of society. Man is not only influenced but he also influences society. Ideal man, in cimic's terms, should soak in and interiorize humanness, that is, those characteristics that represent the theoretical resume of the historical experience of humanity. There is a shift in Cimic's philosophy from the dogmatic to the humanist Marxist position which may contribute to the understanding of the fact that there are still some remains of dogmatism in his teachings. He changed his understanding about the concept of sources of religious beliefs. From the one-source theory, cimic 
shifted to a multi-dimensional approach to the religious phenomenon. 1 As far as the concept of the disappearance of religion is concerned, cimic started with a modified dogmatic Marxist position and ended with the idea that religion will probably always exist, although in a transformed form.

Reality, for ćimic, includes material and ideational elements which are in a dialectical interrelation within the totality of reality. On the basis of this metaphysical concept, Cimic argues that religion is not a simple product of matter.

Contrary to dogmatic Marxism, cimic asserts that ideas in human mind are not a simple reflexion of the socioeconomic conditions of society. Human consciousness, for him, stands in the dialectical relation with the other elements of reality. Accordingly, religious ideas must be approached as multi-faceted occurrences.

$$
\text { ćimic holds that Marx's thought was strongly }
$$

influenced by Hegel, the Young Hegelians, and especially Ludwig Feuerbach. Hegel's influence on Marx is responsible for certain idealistic elements in Marx's philosophy, such as the concept of man's "essential being" which represents an abstract ideal for human beings. Thus, ćimic suggests

IOne of the inconsistences of cimic's system is that although he argues against the supremacy of material structure over superstructure, it seems that he, however, favors the economic factor at the expense of other factors. 
that religion, for Marx, besides being socially and economically generated, represents the striving of man to realize his essential nature. Marx also adopted Feuerbach's concept of religion as a phenomenon which reveals truth about man himself, that is, his essential characteristics. However, according to ćimic, Marx was an original

thinker. Although Marx stated that "the critique of religion is the presupposition of all criticism,"1 he also maintained that it is not sufficient to remain on a theoretical level since religion is not the cause but the expression of alienated man. The social, economic, and political structures which were created by men have become alien powers which tyrannize them. Hence, the social alienation is the basis of religious alienation and one must attack the real conditions which have placed man in this bondage.

There is, in Ćimié's view, no discontinuity or contradiction in the writing of "early" and "later" Marx. The only difference to be found is in the level of approach. While "early" Marx's critique of religion remains on the philosophical and anthropological level, the "later" Marx locates his critique of religion in the historico-social level. The concept of praxis, that is, free man, dominates the writings of both "early" and "later" Marx. Accordingly, ćimic argues that the only legitimate Marxist approach

\footnotetext{
IMarx, The Kar1 Marx Library, 5:35.
} 
toward religious phenomenon is to create conditions for the freedom of man.

Science and religion, for ćimić, cannot deny each other since they do not meet on the essential. While science is competent to speak authoritatively only in the empirical field, religion's competence is located in the area of the a-rational and metaphysical. It implies, contrary to the teachings of dogmatic Marxists, that science is not in a position to eliminate religious illusions. For that reason it pertains to philosophy and not to science to enter into dialogue with theology.

ćimic argues that Marx is essentially a social philosopher, interested in the radical change of the reality of this world. Religion per se is not the main target of his critique. Instead, Marx's focus was on that aspect of religion which contributes to the perpetuation of the oppressive social conditions. In the interpretation of Marx's thought, cimic suggests that the totality of Marx's work should serve as a methodological criterion and not some isolated statements.

After having discussed ćimić's life, education, professional pilgrimage, the starting point of his philosophy, and the ideological basis for his philosophy of religion, this study now turns to his overall concept of religion. 
CHAPTER IV

\section{ĆIMIĆ'S RECONCEPTUALIZATION OF THE DOGMATIC MARXIST CONCEPT OF RELIGION}

The objective of this chapter is to analyze cimic's reconceptualization ${ }^{1}$ of the dogmatic Marxist concept of religious phenomenon. It includes such issues as his view of the basic dogmatic Marxist concepts of religion as they existed in the context of socialist societies, the sources of religious alienation, and the different dimensions of religion. This sequence comes from the inner flow of ćimic's thought itself. We begin by investigating his concept of the various dogmatic Marxist "simplistic" 2 views of religion.

\footnotetext{
${ }^{1}$ In this chapter we analyze cimic's reconceptualization of the dogmatic Marxist concept of religion. In the next chapter we discuss cimic's own concept of religion and its relation to atheism which represents, in his philosophy, the road of liberation from all alienation.

2́cimie views religion as a complex, multi-faceted rather than a simple phenomenon and rejects all dogmatic Marxist simplistic concepts (see Ćimic, Drama Ateizacije, 20-25, 29-50; Ateizam kao Povijesni Humanizam, 61-83; "Marx's Critique of Religion and/or Atheism," 519-524; Socijalisticko Društvo i Religija, 24-33).
} 
141

Basic Concepts of Religious Phenomenon in the context of socialist societies as Viewed by ćimic

Ćimic discusses and reconceptualizes three main concepts of religion generally adopted and practiced by the dogmatic Marxists: the enlightenment-rationalistic concept, the spontaneous-economic concept, and the administrative concept. ${ }^{1}$ In opposition to these, he proposes his own view of religion, namely, the humanist-Marxist. ${ }^{2}$

Enlightenment-Rationalistic Concept

According to ćimic, proponents of the enlightenmentrationalistic concept argue that religion is the consequence

\footnotetext{
IIn praksa i Religija (1960), Ćimic mentions two
} dogmatic Marxist concepts of religion, namely, the enlightenment and psychological concepts, as well as his own humanist-Marxist concept. However, in his doctoral dissertation, Socijalisticko Drustvo i Religija (1966), as well as in an article entitled "Religion and Church in Socialism" (1971), ćimic has dropped the psychological concept (the concept of the nature of religion according to which the locus of man's religious belief is not to be situated in the sphere of man's reason but in the sphere of man's emotions; religion has melted into one and mixed inseparably with man's emotional life) and has added to the previous ones (enlightenment and humanist-Marxist) the spontaneous-economic and administrative concepts. The reason for this change is probably to be found in his understanding that the psychological concept was no longer so widely used among dogmatic Marxists (see idem, praksa i Reliqija, 3; Socijalisticko Društvo i Religija, 13; "Religion and Church in Socialism," in Religions in Yugoslavia, ed. Zlatko Frid [Zagreb: Binoza, 1971], 86-95).

2Idem, Praksa i Religija, 3; Socijalisticko Drustvo i Religija, 22-23; "Religion and Church in Socialism," 86. 
of ignorance. 1 The murky realms of the human mind not yet enlightened by empirical scientific facts are a very fertile ground for religion. ${ }^{2}$ Thus, religion is to be eradicated by the introduction of scientific facts into the human consciousness. ${ }^{3}$ The task of atheistic propaganda is to show the irrationality, absurdity, and unscientific nature of religious superstitions and dogmas. 4 In sum, where reason and science appear, gods and religion necessarily disappear. 5

\section{Cimic argues that this concept overlooks the} interaction between society and religion and takes only the cognitive element as the basic and essential source of religion. 6 It remains in the subjective sphere because it

$1_{\text {The enlightenment-rationalistic concept was first }}$ advocated, according to cimic, in the eighteenth century by French philosophers such as Diderot, Voltaire, Holbach, and Rousseau (idem, Socijalisticko Druśtvo i Religija, 13).

2Idem, Praksa i Religija, 3 ; see also Religion and Self-Management, paper prepared for the First International Conference on Participation and self-Management, Dubrovnik, 1972.

${ }^{3}$ Ibid.

${ }^{4}$ Idem, Socijalisticko Društvo i Religija, 13 ;

"Religion and church in Socialism," 86-87.

${ }^{5}$ cimic puts into the enlightenment-rationalistic category Soviet Marxist authors such as Baskin, Dobrikon, Gurev, Jaroslavskij, Kazdan, Krasnov, Rutner, SklercovStepanov, Tugov, and Ugronevic (ibid., 84; idem, Socijalisticko Društvo i Religija, 14).

\section{${ }^{6}$ Ibid., 13; see also idem, "Politiðko i Idejno} Suoðavanje s Religiskim Fenomenom," in Religija i Društvo, ed. Vjekoslav Mikecin (Zagreb: Ognjena Ptica, 1969), 183196. 
singles out reason as the only source of religion.1

However, religion did not appear in history as a conscious illusion, but as an unconscious product of human fantasy resulting from the natural and social reality of different periods of time, and as unconscious self-defense expressing the real situation of man in the world. 2

Dogmatic Marxist philosophers who propagate the enlightenment-rationalistic view turn a deaf ear to Marx's idea that the abolishment of religion cannot happen on a cognitive level but should rather be the task of changing the real conditions of the world. ${ }^{3}$ Philosophy could not

${ }^{1}$ Cimic recognizes the cognitive element of man's personality as one of the sources of religion, but he is not ready to accept that this is the only source (idem, Socijalisticko Društvo i Reliqija, 15).

2Ibid., 14; "Religion and Church in Socialism," 8687. In this regard Markovic expresses a similar idea when he argues that Marx's philosophy stands in sharp contrast to the entire enlightenment critique of religion. For him, "no amount of atheistic propaganda, scientific education, or political pressure could uproot religion. Religious consciousness would 'wither away' only when human beings would no longer feel an overwhelming emotional need for it, and they would lose that need only when the conditions of their life would change. . . . What is needed is a social change that would allow all individuals to 'stand on their own feet,' to control their own social powers, and to realize their humanity on earth instead of projecting it onto heaven" (Markovie, "Atheism Is Not Essential to Marxism," 529-530).

\section{${ }^{3}$ ćimic, Socijalisticko Društvo i Religija, 15;}

"Religion and Church in Socialism," 88. In this respect, Roter suggests that it is foolish to assume limited intelligence in believers. The Marxist criticism of religion should primarily be a criticism of society and the radical change of social relations rather than criticism of religion itself (zdenko Roter, "Politika i Religija," in Reliqija i Društvo, ed. Vjekoslav Mikecin [Zagreb: 
change the world because it remained merely on the level of theory and interpretation. ${ }^{1}$

Dogmatic Marxist atheism, 2 for Ćimic, as a pure reaction of reason to its presupposition, i.e., religion, is more a protest than the radical critique of religion. It only leaves emptiness in the soul. The enlightenmentrationalistic atheism is blind to the fact of human nature and especially to the element of uncertainty which is closely connected with the human anthropological status. ${ }^{3}$ However, ćimic admits that the knowledge of the

\begin{abstract}
Stvarnost, 1969], 123-129).
1ćimic, Socijalisticko Društvo i Religija, 15;

"Religion and Church in Socialism," 88 . Bošnjak writes that Marx's atheism means something quite different from enlightenment's atheism. The critique of religion, for Marx, cannot be successful without the critique and change of society. It means that it is not enough for atheism to exist as an individual conviction but must become the content of the social consciousness and conviction. This transition from the individual to social atheism cannot be done without social change and revolution. Thus, Bošnjak agrees with Cimic that Marx's criticism of religion presupposes the change of socio-economic conditions. However, contrary to what ćimic holds, he adds the idea that a socialist society must be in constant conflict with religion and must use "the method of persuasion" against religious egoism (i.e., desire for eschatological survival). It is not quite clear, then, what is, for Bosnjak, the difference between the enlightenment-rationalistic's concept of religion and his "method of persuasion" (see Branko Bošnjak, "Kritika Religije," in Religija i Društvo, ed. Vjekoslav Mikecin [Zagreb: "Ognjena Ptica," 1969], 10).
\end{abstract}

${ }^{2}$ For ćimić, dogmatic Marxist atheism remains on the theoretical level and thus it is in many of its aspects identical with the enlightenment-atheistic concept of religion.

3Ćimic, Socijalisticko Društvo i Religija, 15;

"Religion and Church in Socialism," 88. 
nature of religion weakens religious orientation to a certain degree. When one becomes convinced that the supernatural being is not reality but the projection or transcendence of human reality, then faith in the transcendental loses its vigor. ${ }^{1}$ But it is an illusion to think that knowledge can replace religiosity. The source of religion is not to be sought exclusively in the sphere of consciousness as long as man is limited by practical conditions in the realization of his needs. ${ }^{2}$ If realization of man's needs is illusory, he will look for consolation in the religious illusion. The humanist-Marxist concept of religion presupposes an action directed toward the elimination of the social roots of religion. ${ }^{3}$

\section{Spontaneous-Economic Concept}

According to the spontaneous-economic concept, religion is a false consciousness caused by oppressive socio-economic circumstances of the class system. 4 Religion will disappear by itself as soon as the enslaving

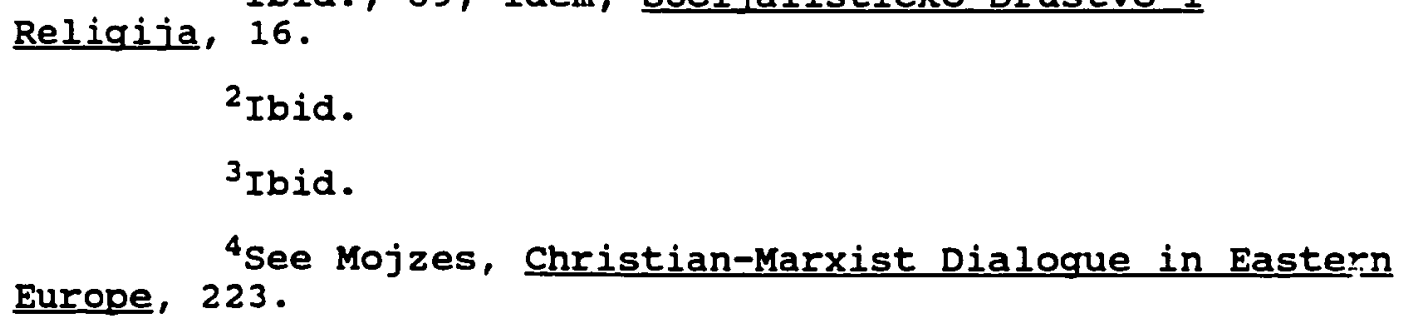


socio-economic conditions cease. ${ }^{1}$ Until then, socialism must make compromises with religion. ${ }^{2}$

$$
\text { ćimic, on the other hand, argues that the political }
$$

and economic solutions are insufficient. ${ }^{3}$ Marx was far from accepting the idea of spontaneous, automatic regeneration of human beings because this would negate the importance of human consciousness and conscious action. 4 Thus, it would be illusory to expect that any social situation by itself would cause automatic change in human beings in either the progressive or stagnant sense. 5 Man's future is an act of men. It cannot be designated as totally

${ }^{1}$ Ibid.

2'imic writes that "in some socialist countries concern with economy has almost entirely won over other forms of judgment. The economic conditions are most often taken as a formula for the direct explanation of all human problems, including the problem of religion. Thus, for instance, a group of leading soviet theoreticians claims that 'religious beliefs existing in a socialist society are not a superstructure over the socialist basis, but only a remnant of the old society, a remnant of the old capitalist superstructure which had been destroyed together with the capitalist basis in the course of socialist revolution" (Ćimić, "Religion and Church in Socialism," 89-90).

3 Ibid., 90.

${ }^{4}$ see idem, Socijalisticko Društvo i Religija, 17. Kerševan expresses a similar idea to ćimic's when he writes that religion possesses a certain autonomy rather than being merely the reflection of socio-economic circumstances. This means that religion cannot disappear by itself in proportion to the development of production forces. For him, religion is basically determined by the reciprocal relationship between human beings and mystery (Kerševan, "Neka Sporna Pitanja Marksistiðke Teorije Religije," 980-993).

$$
{ }^{5} \text { see Ćimic, Socijalisticko Društvo i Religija, } 17 .
$$


certain or totally uncertain because it is human action which leads to a different social situation. 1

In addition, external, objective factors, in ćimic's view, do not act directly on the human mind but through the already existing, subjective structures of one's intellect. That which is external acts by the intermediation of the internal; the internal is the expression of the external, but, at the same time, the internal affects the external. ${ }^{2}$ The human mind would become a real force if its ideas constituted part of the praxis, that is, if the circumstances in which man acts were not established by some historical necessity independent of man, but were at the same time a human deed. ${ }^{3}$ The process of establishing a free personality is the action which would gradually lead to the situation of coordinating subjective demands and objective possibilities. This also would be the beginning of the end of religion as one of the expressions of man's dependence. 4

\footnotetext{
IIbid.; see also idem, "Religion and Church in Socialism," 90 .

${ }^{2}$ cimic states that the dogmatic Marxist teaching according to which men are the product of social and historical circumstances forgets that it is, in fact, people who change the circumstances (ibid.). 17.

${ }^{3}$ Ibid.; idem, Socijalisticko Društvo i Religija, ${ }^{4}$ Ibid.
} 
The Administrative

Concept

According to the administrative concept, the main

reasons for the existence of religion are social

institutions which promote religion (such as, church and

clergy). When the institutional conditions for the

expression of religion are removed, religion will disappear

since the religious person will find no support in society

for the illusion. ${ }^{1}$ Religion can be suppressed by pressure

upon the personality of a religious man and by other

administrative procedures, for instance, physical and

psychological persecution, legal restrictions, job

harassment, and destruction of church buildings. 2

Although this practice, according to cimic, is

directed toward the achievement of human happiness and spiritual liberation of man, it degenerates into something that those who embrace it least want: a new source of religion. The method of applying pressure and arousing fear cannot free man from religion; it only deprives him of his own consciousness, his feeling of personal responsibility, and of much more that actually makes him a man. ${ }^{3}$ The

1see Mojzes, Christian-Marxist Dialoque in Eastern
Europe, 223 .

${ }^{2}$ Ibid; Ćimic, Socijalističko Društvo i Religija, 18; "Religion and Church in Socialism," 91.

${ }^{3}$ see Ćimic, "Politiðko i Idejno suoðavanje s Religijskim Fenomenom," in Religija i Društvo, ed. Vjekoslav Mikecin (Zagreb: Ognjena Ptica, 1969), 191-195. 
persecution of religion does nothing but prolongs its life

and supplies it with the wreath of martyrdom. ${ }^{1}$ Thus,

dogmatic Marxists, by using administrative measures against

religious people, actually delay the moment when religious

life and practice will disappear and create implications

which reflect negatively upon the social transformation. ${ }^{2}$

\footnotetext{
${ }^{1}$ Although Cimic strongly opposes the use of the administrative procedures against religion, he also states that the phenomenon of administrative concept of religion in the socialist countries is understandable and, therefore, to a point is justifiable. He explains his position by saying that this refers particularly to the period after the armed part of a revolution. Religion and the Church usually offer safeguards for the maintenance of the old law and order. (Ćimic mentions the case of the Yugoslav war against the Germans in which the Church offered its help to the invaders). After a revolution, all this is still fresh in the memory, and the distrust of those who think differently results in a mechanical pressure (ibid.).

${ }^{2}$ Cimic mentions the case of Yugoslavia, where any suppression of freedom to express religious beliefs triggered a strong protest by all the theists regardless of their orientation toward a socialist society. The intolerance toward confessional communities annoyed the believers and even discouraged them from participating in the transformation of a socialist society. Moreover, in cases of this kind, the religious communities even gain some reactionary political recognition. The priesthood multiplied advantages in relation to the opposition to the unpopular measures of the authorities. The need for religious zeal increased by the suppression of religious freedom. Later, when the Yugoslav society become more democratized, the number of believers appeared to increase because the number of those who were able to freely express their religious belief increased. Moreover, democratization of society caused a great decrease in the number of those believers who were expressing their political hostility through the confessional communities. Furthermore, the respect for religious freedom directed the believers less and less toward the exploitation of religious communities as instruments for the expression of their national feelings. In summary, freedom of religion had contributed enormously to the isolation of reactionary clericalism and the stimulation of believers and atheists to the building of a
} 
They might be described as people whose political reasoning has betrayed their social instinct. ${ }^{1}$

One of the basic presuppositions of the humanistMarxist concept of freedom, in cimic's view, is freedom of consciousness of all kinds, including religious consciousness. Any pressure upon human consciousness is foreign to true humanism. The socialist state should open a wealth of possibilities both to believers and non-believers to take part in the process of social change. ${ }^{2}$ It should also work on the removal of all the obstacles of a psychological, moral, and political nature in order to create the possibilities for the development of harmonious human personality. Humanist-Marxist atheism does not lose any of its efficacy by creating social conditions of freedom; on the contrary, it retains all the values of social action which aim at the removal of all sources of religious fervor. ${ }^{3}$ A rejected man must seek refuge outside

new society (idem, Socijalisticko Društvo i Reliqija, 19-20; "Religion and Church in Socialism," 91-92).

IIbid.

2 Idem, Socijalisticko Društvo i Religija, 20.

${ }^{3}$ Cimic writes that if the religious consciousness is sincere and deep, it is able to withstand even the strongest blows. Moreover, when the believer is exposed to external pressure, the feeling of anxiety, insecurity, and impotence becomes stronger. Thus, society may push a religious man into the zone of "illegal" devoutness which may only have the appearance of atheistic transformation. The believer continues, within his intimacy, to strengthen the wall of his spiritual myths (ibid., 20-21). 
151

of the world of man, in God, which is the normal result of administrative pressure no matter how much its advocates justify themselves by the distant prospect of heaven on earth. 1

\section{Humanist-Marxist} Concept

According to ćimie, the humanistic Marxist concept of religion differs considerably from those mentioned above. Marx's ambitious project of liberating man is in fact a demand for a revolutionary change of the whole situation in which man is still chained and bound. 2 If one wants to "sympathize" with and destroy man's closed circle of impotence and fear, he should make him participate in the action of changing the world and, thus, himself. The absence of freedom revives man's need for the superhuman and transcendental, which, although illusory, can offer help. ${ }^{3}$ Humanist Marxist atheism goes deep into the root of the matter by trying to fasten upon the conditions which may contribute to the removal of religious myths and incite an

IIbid., 21.

2 The whole situation of man which must be taken into consideration includes the moment of consciousness, the moment of aim, and the moment of volitional decision (idem, "Religion and Church in Socialism," 97).

${ }^{3}$ Idem, Socijalisticko Društvo i Religija, 22; see also "Politiłko i Idejno Suoðavanje s Religiskim Fenomenom," 188; "Religion and Church in Socialism," 95-96. 
illusory hope for the future. ${ }^{1}$ In other words, by examining the social and other hypotheses of man's liberation, it attempts to remove all that lulls man into passivity. This involves the creation of unholy conditions of being human, 2 the path of permanent liberation achieved by the action of men themselves as the creators of their own human destiny (praxis). ${ }^{3}$

\section{Summary}

The hypothesis of the enlightenment-rationalistic concept of religion is that religious belief can be eliminated by atheistic propaganda which reveals the senselessness and the non-scientific basis of religious superstition. Ćimić argues that this concept overemphasizes the cognitive aspect of man as the basic and essential source of religion to the neglect of all others. At the same time, the rationalistic concept forgets that religion is not a conscious delusion but an unconscious self-delusion which reflects the actual position of man in the world. The source of religion does not lie exclusively in the sphere of consciousness, but necessarily stems from the manner and

\footnotetext{
${ }^{1}$ Idem, Socijalističko Društvo i Reliaija, 22.

${ }^{2}$ ćimic uses the idea of "unholy conditions of being human" to designate the absolutely suitable socio-economic conditions for human beings but without God.

3ćimic, Socijalisticko Društvo i Religija, 22. more complete presentation of ćimic's view of religion follows in the rest of this and next chapter.
} 
conditions of life which make the achievement of man's needs and desires impossible.

The spontaneous-economic concept toward religion

defends the thesis that religion will disappear spontaneously in correspondence with the development and improvement of economic forces. Ćimic, on the other hand, argues that economic solutions may solve some but not all of the problems, because it would be illusory to expect that a certain social situation will, by itself, condition any automatic human activity. It is human action that changes the existing order and establishes a new one.

Cimic strongly opposes the use of any administrative pressure upon the personality of a religious man because the method of coercion and fear cannot free man from his religious beliefs but only deprives him of his own consciousness and feeling of personal responsibility. History clearly shows that whenever there was suppression of religious freedom, the need for religious zeal increased. The prerequisite for the lasting success of humanistic atheistic activity in a society is the right to religious confession.

According to Ćimic's reconceptualized humanistMarxist concept of religion, every man must be allowed to act and interact freely with himself and society because every man is a potential believer or potential atheist. Man must depend on his powers, his achievements, that is, on 
himself. Man is, above all, a creative being, and as such, in the situation of real-life existence where his freedom is threatened, he cannot resist the sad and helpless entrance into the world of sacral necessity and sacral fear. 1

Having discussed ćimiદ's reaction and reconceptualization of the dogmatic Marxist concepts of religion as they were present in communist countries, I now analyze his concept of religious alienation and its sources.

\section{Religion as Alienation and Its Sources ${ }^{2}$}

Dogmatic Marxists argue that religious illusion is caused by the corrupted and perverted socio-economic conditions, ${ }^{3}$ and as such it is an alienating force which should be exposed theoretically as illusion and sickness. ${ }^{4}$

\footnotetext{
${ }^{1}$ For further information, see idem, "Religion and Church in Socialism," 95.

"For the definition of term "sources" (izvori), see below, 208-209.
}

${ }^{3}$ The oppressive economic conditions of class society are considered by most dogmatic Marxists to be the principal cause of religious imagination. It is also necessary to mention that some dogmatic Marxists consider ignorance and social institutions which promote religion to be possible sources of religious alienation. However, in dogmatic Marxist view, both ignorance and religious institutions do not have any autonomous value since they are also the product of erratic economic circumstances. ćimic, on the other hand, argues that, for instance, anthropopsychological sources of religion have relative autonomy in regard to socio-economic conditions. Thus, he affirms the multiplicity of relatively independent sources of religion which act together in producing religion (for further information on dogmatic Marxism, see Mojzes, ChristianMarxist Dialogue in Eastern Europe, 222-223).

${ }^{4}$ Bockmuehl, 57-58. 
ćimic, on the other hand, maintains that religion may be a form of human alienation; ${ }^{1}$ however, for him, religion rather than being caused by one principal source (i.e., socio-economic) has, at the least, four relatively autonomous sources which can became the source of alienation. ${ }^{2}$ The sequence of my analysis is determined by the fact that only when the concept of religion as alienation is grasped can one understand the cause of that alienation, that is, its sources. Thus, before we discuss cimie's understanding of the sources of religious alienation, we must analyze his view of religion as alienation.

Religion as Alienation ${ }^{3}$

ćimic suggests that Hegel's and Feuerbach's concepts of alienation are to be seen as prime factors which influenced the formation of Marx's idea of alienation. ${ }^{4}$ In Hegel's view, Absolute spirit in the process of its selfaffirmation negates (i.e., alienates) itself by generating

\footnotetext{
1'́imic, Drama Ateizacije, 55.

${ }^{2}$ The socio-economic source, the socio-psychological source, the socio-cognitive source, and the socio-moral source (idem, Ateizam kao Povijesni Humanizam, 54).

${ }^{3}$ In general terms the concept of alienation "denotes the processes, or result of processes, whereby a person or thing expresses itself in a form of something foreign or even opposed to itself" (Denys Turner, "Alienation," The Westminster Dictionary of Christian Theology [1983], 11).

4Ćimić, Ateizam kao Povijesni Humanizam, 51.
} 
its opposites through nature and human beings in a series of progressions. Absolute spirit finds the return to itself in man since man is the highest expression of spirit. Christian doctrine of incarnation represents the highest form of the Spirit's progression of the alienation and return to itself. ${ }^{1}$ Feuerbach reversed the Hegelian process by arguing that when man affirms God, he negates himself. In other words, in religion man affirms himself in the form of an alien object over-against himself. ${ }^{2}$ Although Marx, like Feuerbach, reversed Hegelian process by contending that God is the self-alienation of man, and thus embraced Feuerbach's criticism of Christianity, he went much further by asserting that religious alienation is primarily rooted in man's social alienation. ${ }^{3}$

ćimic continues by arguing that man is, above all, a being of praxis. Praxis is something specifically human and includes the elements of consciousness, aim, and willing decision. 4 Man as a being of praxis is the wholeness of his existence, which is multi-dimensional. ${ }^{5}$ while the

\footnotetext{
1Ibid; see also Turner, "Alienation," 11.

2Ibid; ćimic, Ateizam kao Povijesni Humanizam, 52.

3 Ibid.

${ }^{4}$ Ibid., 51; see also idem, "Religion and selfManagement," 136-138.

${ }^{5}$ The concept of "praxis," as understood by ćimić, implies that man is "a being of possibilities" (idem, Drama Ateizacije, 178). This idea seems identical with the existentialists' proposition: "existence precedes essence."
} 
existence of other living beings is directly determined by nature alone, man is influenced by nature, society, and history. In addition to that, he also influences history and changes nature and society. ${ }^{1}$

Thus, in general terms, in cimic's view, the essence of Marx's concept of alienation is to be found in the separation of the social phenomena (man's work, man's social relations, and the products of man's work) from man's own will, power, and control. 2 These social dimensions, when transformed into autonomous powers which behave on the basis

By this, existentialists mean that man, unlike natural things, objects, and organisms, does not have his essential nature given to him as an already realized possibility, but that man is separated in his actual existence from his essential nature which lies before him and is yet to be realized. This reverses the traditional view which sees man as having a relatively fixed nature (Richmond, "Existentialism," 202).

${ }^{1}$ Cimic states that people, because of the durability of their structures, greatly transcend the concrete situations. Society can influence people to some extent, but they are not made of wax, so society cannot make copies or schemes of people or it would result in a negative influence on individuals. Cimic here makes allusion to the administrative approach which was often used in the communist states under the pretext of creating a better future (see ćimić, Drama Ateizacije, 51; Uvod u Marksizam, 46; "[Ne] Zaboravljeni Bog," in Covjek od Straha [Belgrade, Ljubljana: Partizanska Knjiga, 1986], 51-69).

${ }^{2}$ Marinkovic expresses a similar idea in his understanding of alienation. For him, alienation is a denial of the eternal imperative for self-creation caused by the appropriation of nature and turning it into property. He also argued that the concept of the mechanistic dependence on the economic sphere must be abandoned. For him, there are many forms of alienation which do not depend on economic alienation (Edo Marinkovic, "Marksizam: Sistem ili Inspiracija," Crkva u Svijetu 4 [1969]: 406-407). 
of their own laws independently of human will, become a blind necessity that prevents man from being a being of praxis. $^{1}$ consequently, alienation consists of the loss or absence of one or more dimensions which determine man's humanness ${ }^{2}$ and cause him to differ from everything else. 3 In other words, alienation is the absence of man's "genetic being" 4 which depends on the wholeness of social relations. 5

Alienation in religion is primarily seen in the exchange of the immanent chaotic social conditions for the

${ }^{1}$ Ćimic, Ateizam kao Povijesni humanizam, 52; see also "Structure de la conscience religieuse dans les milieux rouraux et urbains," 173-179.

2́́imić's term "humanness" designates "man's genetic being," that is, the essential dimensions of man (consciousness, willful decision, aim). These characteristics are the result of the historical experience of humanity (see idem, Ateizam kao Povijesni Humanizam, 61). Cimic uses the terms "man's genetic being" and "humanness" synonymously with Marx's terms "essential being" or "species essence" which, in Marx's philosophy, denote an ideal or pure state which transcends human subjective cognition and concrete social-historical cognition. It exists as human potential (see above, 31, 57-58, 73-74; Gorman, Neo-Marxism, 74-85; see also Marx, Grundrisse, 172-173, 323-325, 539$542)$.

3cimic's idea of alienation is similar to existentialism's concept of "fallenness." Existentialists contend that human existence is in greater or lesser degree estranged from its true, genuine, or authentic modes. Consequently, they speak of the possibility of the transition from false to genuine mode of existence (Richmond, "Existentialism," 202).

${ }^{4}$ See n. 2 above; Ćimic, Ateizam kao povijesni Humanizam, 61 .

5 Ibid. 
transcendent, in the establishment of the schism between actual existence and the eschaton, and in the creation of the double essence of everything existing. 1 This schism, or negative dualism in religion, consists of the creation of two worlds, of which the second one has a compensative role. The possibility of an other-worldly solution almost always diverts from risky this-worldly action. ${ }^{2}$

In religion, man is usually discouraged from trying to change the actual erratic situation in which he is imperilled. 3 He is a divided being who looks for and seemingly finds his wholeness in the other-worldly

${ }^{1}$ see idem, Drama Ateizacije, 55. In this respect Veres suggests that Marx's concept of alienation includes two forms: practical and ideological. The practical form includes economic, social, and political alienation. The theoretical form includes religious, philosophical, and artistic alienation. An alienated person is one who does not bring about his or her historically available potential in the given sphere of human activity. Economic alienation is the fundamental alienation as well as the source of all other alienation. The fundamental characteristic of all alienation is that some inhuman power rules over the lives of people who are caught up in the alienating relationship. For example, it is not only the exploited but also the exploiter who is alienated. Alienation perverts the free and creative production which is the basic human activity. The positive humanism of Marx's concept of alienation is the dream of complete independence of the human being from any control, natural or supernatural (Vereš, 48).

2́cimić, Drama Ateizacije, 55; see also "(Ne) Zaboravljeni Bog," 58-61.

${ }^{3}$ ćimic also suggests that some aspects of religion (religion as a desire of man to transcend the erratic social circumstances) may represent a motivation for action toward the establishment of the real historical humanism (idem, Ateizam kao Povijesni Humanizam, 74). 
reality. ${ }^{1}$ However, the more the religious picture which man creates of himself is positive and ideal, the more his wholeness is endangered. 2

Therefore, man is alienated not only when he lives under the oppressive social economic conditions (although they play an essential role in human alienationj, but at anytime when he is not able to express himself as a being of praxis which includes his consciousness, aim, and willing decision. Religion may be an alienating force because it could be an obstacle for the realization of a human being as a being of praxis, since in religion man is often

discouraged from trying to change the actual erratic situation in which he is imperilled.

Now that we have seen how cimic defines his concept of religion as alienation, we are ready to discuss his view of different sources of religious alienation.

\section{IIbid., 53; idem, "(Ne) Zaboravljeni Bog," 60-61.}

${ }^{2}$ However, ćimić points out that in man's revolt against the destiny offered to him by the erratic social circumstances, it is possible that his revolt against that which is this-worldly be transferred into the revolt against the other-worldly. Here may lie the source of apparent atheism, because economic crises and wars may result in the abandonment of the traditional or conventional God. But, although certain people in these situations reject the traditional form of religion, they do not deprive themselves of the need for religiosity (idem, Ateizam kao povijesni Humanizam, 54). 


\section{Sources of Religion as}

\section{Alienation}

It is possible, according to ćimie, to designate in the framework of Marx's theory of alienation at least four different sources of religion: socio-economic, sociopsychological, socio-cognitive, and socio-moral.1 The isolated analysis of each of these sources (dogmatic Marxist method) would fail to take into account Marx's concept of totality. Only their interactional linking, as well as constant interpretation in their socio-historical context, remains in the line of Marxist thought. For that reason, it is indispensable, according to ćimic, to add to all of these sources of religion the attribute "social" in order to precisely point out that all of these spheres (economic, psychological, cognitive, and moral) are necessarily interwoven in the socio-historical level. However, this does not exclude, but implies, certain autonomy of religion and its onto-anthropological status. ${ }^{2}$

The Socio-Economic Source of Religion

Man who lives in the real world of class society must necessarily have the need for the unreal compensation

\footnotetext{
${ }^{1}$ Ibid.

${ }^{2}$ Ibid., 54-55; see below, 208-210.
} 
found in religion. ${ }^{1}$ separated from his genetic (essential) being $^{2}$ in the rude reality of life, in the imaginary world of religion, man alienates himself by transforming his feebleness and powerlessness into God's all-powerfulness. 3 Powerless, yet not wanting to be powerless, he creates almighty God in order to help him. In reality, he is only duplicating himself.4

Even the man who has enjoyed the advantages and privileges of his class position here in this real world may accept religion in order to secure these benefits and extend them into eternity. 5 He does not need religion in order to improve his this-worldly life. What he needs is the possibility to transcend this-worldly confines of life. Thus, religion becomes for him the protector not only of

\section{${ }^{1}$ see Ćimić, praksa i Religija, 4 ; Socijalistiðko} Društvo i Religija, 37; Drama Ateizacije, 50-53; Ateizam kao Povijesni Humanizam, 55; "Odsustvo vjere u sebe Trazi vjeru U Boga," Odjek 18 (1964): 14-19.

2Ćimic here uses the term "man's genetic being" to refer to the essential characteristics of human beings: willing decision, aim, free consciousness (i.e., praxis) (see idem, Ateizam kao Povijesni Humanizam, 51).

${ }^{3}$ Idem, Socijalistiðko Društvo i Religija, 37; see also "Marx's Critique of Religion and/or Atheism," Journal of Ecumenical studies 3 (1985): 519-524.

4Ibid. The influence of Feuerbach on cimie is evident. Feuerbach argued that religion is nothing but the projection of human attributes into an imaginary being of perfection (see McGovern, 16).

${ }^{5}$ Ćimic, Ateizam kao Povijesni Humanizam, 55; see also "(Ne) Zaboravljeni Bog," 52-54. 
this-worldly interests but also of other-worldly ones. ${ }^{1}$

In other words, religion, for ćimic, is a picture of the earthly life with its real needs transported into an unreal, illusory world. However, religion can maintain itself only as long as it stands in the form of promise in relation to man's interests and aspirations. 2 Therefore, it is social inequality, as the main characteristic of class society's structure, that appears as an essential alienating factor which intensifies aspirations for religion rather then some search for a universal truth. ${ }^{3}$

${ }^{1}$ Idem, Socijalistiðko Društvo i Religija, 38; see also Dogma i sloboda, 120-127; "Structure de la conscience religieuse dans les milieux rouraux et urbains," 173-175.

${ }^{2}$ Idem, Ateizam kao Povijesni Humanizam, 55.

${ }^{3}$ Ibid. Bošnjak claims, contrary to ćimić, that death and suffering are the essential sources of religion. He states that religion can survive in all social systems because it cannot be reduced to socio-politico-economic relations. By virtue of its essence, every religion transcends reality and aims toward that which is the 'eschaton.' Thus, no social system can be a barrier for religion. Marxist philosophy has considered religion to be much simpler than it is. The suppression of religion is not so simple, because it is not the truth of religion that determines its duration but the will of those who wish to exclude themselves from natural processes and accept the hope of eternal life. Therefore, the key to the permanent endurance of religion is the human desire to find purpose in the life full of suffering and to attempt to find meaning in a situation where there is none. In sum, religion is the human desire to overcome death (Bošnjak, Filozofija i Kršcanstvo, 363-369). Kerševan argues against Bošnjak and agrees with cimic that suffering and death are not the essential source of religion. For him, as well as for cimic, religion provides another world which affirms the freedom and full realization of the human being contrary to the rude realities of this world (Kerśevan, "Teoretski Model za Proǔavanje Religije kao Specifične Prakse," 732-734; "Savremeno hrišćanstvo i Ideologija," 78-79). 
The Socio-Psychological Sources of Religion

Cimie maintains that in the analysis of human intimacy, as nowhere else, it is possible to discover the abundance of the different sources of religion. ${ }^{1}$ The psychological life of man is not something independent, isolated from the wholeness of his life. It is true that the personality of an individual is relatively independent and expresses itself in a special way, yet this individuality cannot be considered as something autonomous from the social context to which it is related and by which it is influenced. ${ }^{2}$ Thus, in the psychological life of man, all sources of religion are somehow interwoven, though they each have their own special manner of expression. ${ }^{3}$ There are, at least, three different psychological sources of religion: anxiety, mortality, and vulnerability.

Anxiety. Usually people are filled with anxiety, not because they are afraid of some unidentified forces, but because they live in a society in which they are dependent. 4 Religion as an illusory overcoming of anxiety

Í́imic, Praksa i Religija, 5 ; see also (Ne) Zaboravljeni Bog," 52-58; "Religija kao Psinicka i Moralna Cinjenica," Preqled 60 (1970): 23-27.

${ }^{2}$ Idem, Praksa i Religija, 6; see also "Structure de la conscience religieuse dans les milieux rouraux et urbains," 173-174.

\footnotetext{
${ }^{3}$ Ibid.

${ }^{4}$ Idem, Socijalistið̌ko Društvo i Religija, 38.
} 
is the best sign of real dependence. ${ }^{1}$ It removes dread and fear by an apparent certainty. Thus, religion is, above all, the subjective expression of man's dependence on society and its shortcomings. 2

Mortality. Although nature as a whole, according to ćimie, is endless, in its parts it is finite and mortal. The tragedy is that there are elements in the nature of man which demand an answer, a solution, but the solution is outside of man's possibilities. ${ }^{3}$ Man as a conscious and cognitive being can hardly accept the fact of a gradual process of inevitable disappearance. 4 Permanently existing

${ }^{1}$ Cimic states that when a believer relates to a deity in a dependent way, not only accepting but asking to be God's servant, he is not supposed to forget God and His presence at any moment. If he does, he is overwhelmed by the feeling of guilt and sin. This is the way religion constantly attempts to control all of man's motives and actions (idem, Drama Ateizacije, 30 ).

2Idem, Praksa i Religija, 5-6. Whenever Ćimic states that religion is socially caused, he has in mind primarily the roots of religion, not the basis of religion (see below, 208-209).

\section{3Ćimić, Socijalisticko Društvo i Religija, 39.}

${ }^{4}$ Kerševan, in this respect, states that although Marxism has said little about the meaning of life, happiness, and other issues concerning human existence, Marxists did not spare any efforts in "regard to basic social goals, thereby, in fact, giving meaning to a larger number of people than any other movement, including religion, which continuously talks about meaning." Marxism, according to Kerševan, has inspired more people to sacrifice for the sake of humanistic values than any other movements which propagate humanistic values. However, the weakness of Marxism is that it does not compete successfully with religion which is primarily concerned with the so-called "last questions" (Kerševan, "Odnos Komunista Prema Religiji," 897). 
between the need for eternal life and the early understanding of the finite, limited nature of every living being, man creates the illusion of immortality and transforms it into possible reality. ${ }^{1}$

Thus, although there are many unsolved questions and puzzles in life, it is the phenomenon of death which plays an important role in the origination of man's fear. ${ }^{2}$ often man's preoccupation with the phenomenon of death pushes back all other fears and tensions in life. For that reason, the existence of other-worldly goals serves as a compensation for many frustrations through which human beings pass in the process of the realization of their human needs and desires. ${ }^{3}$ By giving to man an existence beyond this world, religion makes it possible for an individual to interpret each catastrophe of life as less important and secondary because the path is always kept open toward final happiness.

${ }^{1}$ cimic writes that the modern priest plays the role of the psychiatrist, especially when people are practicing confession. Many people come to the priest tired of life, broken under the burden of everyday pressures and problems, imprisoned by their limited possibilities, wanting to cast off their burdens. The priest sits in a dark room, perhaps with quiet background music, and pronounces some mysterious words. He is apparently helping man by altering his identity. Man becomes convinced that he is not himself while living in this world, but that he is going to a heavenly realm where he will not be threatened by any limitation, powerlessness, or loneliness. What the priest is doing is further dividing the already divided personality of man (Ćimić, Drama Ateizacije, 31).

$$
\begin{aligned}
& { }^{2} \text { Ibid., } 31 . \\
& { }^{3} \text { Ibid. }
\end{aligned}
$$


In fact, religion is a form of philosophy of consolation and comfort which helps man to consider tragedy not as something ultimate but as merely provisional and temporary. ${ }^{1}$

Vulnerability. In the most difficult and most fateful moments of his life, although he knows that God is not helping him, man leaves a space where God can take "refuge" in order to create the possibility for himself to take refuge. Over and over again, man wants to give God a chance and wants to prevent himself from getting discouraged with God, that is, with himself. ${ }^{2}$ God is for him the last and the highest asylum that he is afraid to get rid of as long as he is existentially imperilled, and as long as the causes of that imperilment remain unknown to him. ${ }^{3}$

The explanation for the existence of religious feelings in the primitive (poor and uneducated) societies may be undeveloped consciousness, poor education, low level

\footnotetext{
${ }^{1}$ cimic states that the fear of death represents an important source of religion. He illustrates this by giving an example of the research which shows that religious persons have learned almost everything about death in the early period of their life, much earlier than those who are not religious. Eighty percent of those who have declared themselves to be religious become aware of death in the period before the age of six years. Only thirty percent of those who declared themselves to be non-religious have had the same experience. Here cimic comes very close to Bošnjak's view that the fear of death is the essential source of religion. However, contrary to Bošnjak, ćimić points out that religion is the result of several sources and cannot be reduced to one source (see ibid., 34; Bošnjak, Filozofija i Kršcanstvo, 373).

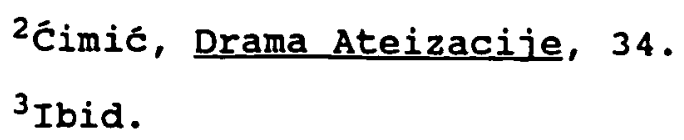


of culture, unfavorable social and economic status, or low intellectual level.1 But how does one explain the very strong religious feelings of the group of people who are on the other extreme of the economic and intellectual scale? The rationale for these phenomena is to be found in sociopsychological factors, of which the domination of formal and professional communication among men, individualism, and isolation play the most important roles. ${ }^{2}$

Therefore, the dependence of the unpredictable socio-economic circumstances, the early understanding of the finite nature of every living being, and the professionalism in human relations intensifies the feeling of internal imperfection which is the root of the inferiority complex. The inferiority complex, in turn, stimulates religious activity. Rational persons, who more or less succeed in acting in a rational way in contemporary society, when faced with the irrationality of the socio-economic circumstances, feel isolated, suffer the lack of human communication, and pass through strong internal conflict whose result is, in most cases, the acceptance of religious alienation. ${ }^{3}$

${ }^{1}$ Idem, Socijalisticko Društvo i Religija, 39.

2 Ibid.

${ }^{3}$ ćimic writes that religion provides the individual with the feeling of importance and security. Religion enlarges man's ego by making it important for the universe and the universe important for himself. For example, when a man enters the age of puberty, gets married, has children, divorces, or becomes very old, religion helps him to be able to adjust in the new situation and to accept changes, though 
The Socio-Cognitive Source of Religion

Cimic states that the constant increase of human knowledge in almost all spheres of reality deserves admiration because it represents an important element in the process of man's liberation. ${ }^{1}$ However, cognition alone is not able to eliminate man's dependence and helplessness. Increase of knowledge may represent only one aspect of the process of elimination of human alienation, but it is not the only one, as it is sometimes maintained by dogmatic Marxists. ${ }^{2}$

If one looks back into history, one realizes that humanity knew very little. The comparison of this little knowledge in the past with what man knows today may fill the human mind with pride and satisfaction. ${ }^{3}$ However, if one turns his regard toward the future and toward areas which are still to be conquered by the human mind, man becomes less satisfied and even unhappy. 4 space travel, for example, may mean for some that the roots of religion are imperilled; however, they are not eliminated. 5

they may be very unpleasant (see idem, Ateizam kao Povijesni Humanizam, 55-56; Drama Ateizacije, 34-35).

${ }^{1}$ Ibid. , 42-50.

2Idem, Socijalistið̌ko Društvo i Religija, 41.

${ }^{3}$ Ibid.

${ }^{4}$ Idem, Drama Ateizacije, 46.

${ }^{5}$ Idem, Socijalisticko Društvo i Religija, 41. 
The structure and the space of nature are endless. Nature produces numberless combinations, and the universe cannot be known in its entirety. ${ }^{1}$ The cosmos is without limits and in the state of constant movement and change. As soon as man succeeds in his adventure of knowing one element of the universe, that element is already transformed by the play of natural laws and, thus escapes human cognition. 2 Therefore, since man is a self-conscious subject, he is constantly engaged in the adventure of learning about that which is outside of himself as well as about his internal being. But, to the basic existential questions, such as "wondering at the miracle of being," the question concerning the meaning of existence and the eschaton, questions which may be called "eternal human questions," there is no final answer. ${ }^{3}$ That is why these unanswerable questions, this lack of knowledge, may be the source of

\footnotetext{
${ }^{1}$ Ibid., 42; see also idem, "(Ne) Zaboravljeni Bog," 66-67; "Structure de la conscience religieuse dans les milieux rouraux et urkains," 175-179.

2 Ibid.

${ }^{3}$ Idem, Drama Ateizacije, 50; "(Ne) Zaboravljeni Bog," 54-56. Stefica Bahtijarevic disagrees with cimić that religion offers one of the best answers to the so-called "last questions." She writes that it is important to notice that religion is not the only thought frame, the only answer to the questions concerning the human existence. There are other systems and thought frames where man can find satisfactory answers imposed by his existence and the human situation in general (stefica Bahtijarevic, "Religijska Situacija: Od Teorijskog Pristupa Do Rezultata Istrazivanja," in Religija i Društvo, ed. Siniša zrinšcak [Zagreb: RO Za Graficku Djelatnost, Samobor, 1987], 83).
} 
171

religious beliefs which claim to be able to help man with the puzzles of life. 1

The scientist, ćimic maintains, has no advantage over other people as far as the "eternal human questions" are concerned. The knowledge of the modern scientist (for example, in the area of genetics) is so detailed, partial, and specialized, that he is not able to have an overall cognition of reality. For that reason, he is obliged to look to philosophy or religion for the answers concerning reality as a whole. ${ }^{2}$

Cognition must be considered as a specific category of social practice. Man's consciousness is in the social being itself and is the result of man's efforts to make his existence meaningful. ${ }^{3}$ The social being strongly influences this active human attitude by giving to it a specific content and limitation. 4

Accordingly, it is necessary to keep discovering the

Isee Ćimic, Drama Ateizacije, 50.

2 Ibid., 46.

3Idem, Socijalisticko Društvo i Religija, 43.

${ }^{4}$ cimic states that it is possible to find in everyday life a highly educated people who, regardless of their education, are not liberated from their dependence and alienation (primarily religious alienation). The ultimate cause for this is to be found in their socio-economic dependence and absence of freedom. In the conditions of social passivity and being merely objects in the hand of social chance, these people turn their eyes toward heaven and overlook their social dependence (ibid.; idem, "(Ne) Zaboravljeni Bog," 58; Socijalisticko Društvo i Religija, 42). 
most favorable social conditions which would help in the creation of the true, clear, and demystified consciousness and which, at the same time, would contribute to the process of elimination of the crippled forms of human spiritual activity, that is, alienation. ${ }^{1}$ knowledge is not to be expanded in order to get rid of religion but in order to liberate man from all alienating factors, change the world, and realize the most humane life possible. ${ }^{2}$

The Socio-Moral Source of Religion

\section{ćimic argues that the drastic discrepancy between} what man can do and what he wants to do, usually caused by distorted socio-economic conditions, may often instigate man to commit some inhumane, immoral acts. ${ }^{3}$ After having committed these acts, which are considered to be negative on the basis of the system of moral values, man is usually

\footnotetext{
${ }^{1}$ Cimic states that "the existential categories-queasiness, sliminess, absurdity, boredom, death as destination, unsuccessful project, failed attempt--which were given by Sartre, Heidegger, Camus, Jaspers, Bataille, may be very happily incorporated into the theses of the lack of socio-economic prosperity for the complete happiness of man" (ibid., 43; idem, "[Ne]Zaboravljeni Bog," 58).

2Idem, Socijalistiłko Društvo i Reliqija, 43.

${ }^{3}$ Ćimic defines moral standards as a group of unwritten norms which regulate the relations between man and man and between man and community. The basis of Marxist morality, according to cimic, ought to be found in the human being's ability for direct compassion without self-interest and in the instinct for the preservation of the species (idem, Ateizam kao Povijesni Humanizam, 57; Uvod u Marksizam, 89; Coviek na Raskršču, 127-128).
} 
burdened with a guilty conscience. During these moments of mental tension, man is looking for comfort and for someone to whom he can unburden his mind. Religion offers itself as an excellent solution. ${ }^{1}$

on the theoretical level, there is no final solution to the problem of the cleft which exists between man's inclinations and moral law, that is, between happiness and virtue. On the religious-theological level, this same cleft exists between human 'is' and divine 'ought'. ${ }^{2}$ on the social level, this cleft deepens whenever the socio-economic dependence of man increases. The moral torture of the personality becomes more dramatic in proportion to the increase of existential anxiety. The conflict between life's desires and the impulses of man, on the one hand, and socially unpredictable and unknown obstructions, on the other, brings forth fear. ${ }^{3}$

However, Cimic suggests that whenever these socioeconomic obstructions become predictable and somehow understandable for the human mind, there is hope. Hope is an indispensable dimension of human existence. Men do not

\footnotetext{
${ }^{1}$ Idem, Drama Ateizacije, 37. For further information, see also "Structure de la conscience religieuse dans les milieux rouraux et urbains," 175-179; "Religija kao Psihicka i Moralna Činjenica," 19-23.

${ }^{2}$ Idem, Drama Ateizacije, 38.

${ }^{3}$ Ibid.
} 
exist only in the past, nor in the present, but in their permeation with the future. ${ }^{1}$

Therefore, if man is able to understand social problems and to have hope in a better future, the cleft between pure moral necessity and individual impulses, between general social norms and "laws of the hearth," would result in a kind of internal unity. The weakening of social insecurity leads to a stronger moral personality in man, which contributes to the weakening and transformation of the religious-theological moral presuppositions as the source of human alienation. ${ }^{2}$

\section{Summary}

That man is alienated means that he has lost one or several dimensions which determine his himan nature and which make him different from everything else. Historically speaking, alienation had been created when the social phenomena (man's power to work and products of man's work) were separated from the domain of man's decision and power. Thus, human alienation may be caused not only by the oppressive socio-economic conditions but by various factors which prevent man to realize himself as a being of praxis. Religion as alienation is the expression of human dependence and, as such, signifies the evasion of man from

\footnotetext{
${ }^{1}$ Ibid.

2Ibid; see idem, "Marx's Critique of Religion and/or Atheism," 519-522.
} 
himself as well as the protest against that escape. In religion, man alienates or transforms his being into another power in the imaginary world and, thus he is prevented from being a being of praxis. Ćimic mentions four sources of religious alienation.

First, the socio-economic inequality, whether in a socialist or capitalist society, as one of the basic characteristics of class society, may be one of the factors which contribute to the intensification of religious feelings as the imaginary removal of real human burdens. Uncontrollable socio-economic forces as well as irrational, unpredictable, and unregulated forms of use of the political authority, strongly influence the maintenance of religion. Man feels powerless, almost insignificant, in the face of the huge administrative apparatus created and maintained by contemporary society which threatens to destroy his humanness and to push him into the unreal world of religion. 1 Thus, for the world of technology which divides man's being into alienated parts, the only solution is in the continual effort to create true human societies in which human personality is able to develop in accordance with true human needs.

Second, the intensification of religion in society is also a sign of the fact that man suffers from loneliness, professional communication, individualism, and isolation.

\footnotetext{
${ }^{1}$ Idem, Drama Ateizacije, 55.
} 
176

Living in permanent tension between the awareness of the process of his constant, gradual, disappearance and his need for eternity, man creates an illusion of immortality. All these socio-psychological sources of religion may be, at least partially, eliminated by establishing the right relations between the different forms of personal and social life.

Third, the unlimited nature of the cosmos, as well as its continuous process of movement and change, may be the cause of man's feelings of insufficient intellectual perspective resulting in religious belief. However, knowledge about the origin of certain phenomena in the world does not itself necessarily mean the liberation of alienation because it is partial and limited. Human consciousness is the result of man's efforts and actions toward society and nature by which he attempts to give meaning to his existence. If these actions are not free and creative, they produce a distorted consciousness which in turn, may produce religion. Thus, it is necessary to create social conditions in which it would be possible to realize the most humane life possible in order to free man, not to get rid of religion.

Fourth, a guilty conscience, which is the result of wrong personal actions often caused by unfortunate social conditions, may lead man to attempt to look to religion for support and for unburdening himself. The creation of a 
society in which the variance between the human being's desires and his "oughts" is more and more nullified, greatly contributes to the formation of true and free men, liberated from all alienation, including the religious one.

Therefore, religion is a form of human alienation caused not exclusively by the oppressive socio-economic conditions, as dogmatic Marxist argue, but by various factors which have a relatively autonomous character and which may act together in preventing man to realize himself as a being of praxis.

Having discussed ćimić's reaction and reconceptualization of different concepts of religion as they existed in the communist countries, and his reconceptualized notion of the different sources of religion as alienation, we now turn to his view of the different dimensions of religion. This sequence is due to the inner flow of Cimic's thought itself.

\section{Different Dimensions of Religion According to ćimić}

In opposition to dogmatic Marxist concept of religion as a simple reflection of economic substructure, 1 ćimic argues that religion is a multi-faceted and complex

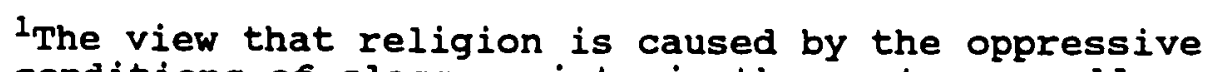
economic conditions of class society is the most generally accepted position among dogmatic Marxists (see above, 4146) . 
phenomenon. Thus, he discusses four different dimensions ${ }^{1}$ of religion: religion as belief in the supernatural, religion as belief in the holy, religion as a system of rituals and customs, and religion as a supply of moral definitions. ${ }^{2}$

\section{Supernatural Dimension}

Belief in the supernatural or unnatural, or in the existence of something that can never be reached by human senses, is, in cimic's view, one of the basic definitions of religion. ${ }^{3}$ However, religion is not, as it could be understood, a kind of exit from the human world, but only a kind of exit from the world of man's conscious cognition. 4

${ }^{1}$ Cimic uses the word "dimenzije" which has identical meaning with English "dimensions."

2́cimic, in Drama Ateizacije, 20, acknowledges that in dealing with these different dimensions of religion he was influenced by the work of Glenn Vernon, especially by his book Sociology of Religion (New York: McGraw-Hill Book Company, 1962). Vernon has taught sociology at several universities in the United states and has written many articles in the fields of religion and sociology. He also has authored several books dealing with the subject of sociology (for example, Sociology of Death [New York: Ronald Press Company, 1970] and Human Interaction [New York: Ronald Press Company, 1965]).

3cimic, Drama Ateizacije, 20. In this respect Pavicevic writes that the first and basic component of religion is the idea of a supernatural, other-worldly being. This concept, according to him, has developed spontaneously under the influence of human feelings and imagination (Vuko Pavicevic, Sociologija Religije [Belgrade: Beogradski IzdavaCko-Grafiðki Zavod, 1988], 15).

${ }^{4}$ Ćimić, Drama Ateizacije, 20-21; see also Socijalisticko Društvo i Reliqija, 24-26. 
The supernatural, in cimic's view, appears on the other side of the limits of human cognition and apparently escapes the limits of natural and social laws. One may argue that precisely these limits are the cause of these supernatural and unnatural phenomena in which the human spirit is interested but which he cannot understand by using the categories which he has at his disposal. 1

In different historical, social, and cultural conditions, the limits of what is "known" and "natural" are differently set, so that the different aspects of the "unknown" are being transformed into the series of supernatural forms. Wherever the human spirit succeeds in penetrating and enlightening natural and social phenomena, it does nothing but place the singular and unrepeatable into the category of the general and lawful. ${ }^{2}$ The only way that human cognition operates is by classifying the different

\footnotetext{
${ }^{1}$ It seems that on this point the philosophy of Kant influenced cimic's thought. Kant asserts that the forms perceived through sense experience are the product of the categories of the human mind, that the externality so encountered is never known as it is in itself (as "noumenon"), but only in relation to man (as "phenomenon"), and that, as a result, reason is barred from any cognitive penetration into the noumenal. Thus, since our knowledge of even material things is conditioned by the mind, all claims to knowledge of reality above the physical world must be likewise conditioned. Although ćimié does not embrace all these philosophical details, he maintains that theological and metaphysical knowledge involves hopeless contradictions that the human mind is not equipped to resolve (see Immanuel Kant, The critique of Pure Reason, in Great Books of the Western World, ed. Robert Maynard Hutchins [Chicago: William Benton, 1952], 1-4, 14-20).

2́́imic, Drama Ateizacije, 21.
} 
aspects of a multi-dimensional reality under the general categories of the mind. 1

However, Cimic states that so often the human mind has demonstrated its impotence and has become aware of its own powerlessness. There remain many aspects of reality, especially in the area of human needs and desires, which are for man as real and true as the objective world in which he is situated, but which cannot be placed under the category of the general and lawful. ${ }^{2}$ These aspects of reality which cannot be categorized as general become the direct instigators for human religious disorientation. ${ }^{3}$ Consequently, belief in the supernatural originates as the result of these conflicts and as an attempt to solve them. The help which apparently comes from the other-worldly area is nothing but the projection of human desires and hopes to the transcendent heaven of faith. ${ }^{4}$ Thus, the belief in a

\footnotetext{
IIbid.

${ }^{2}$ cimic here makes allusion primarily to the socalled "last questions" (ibid).

3It seems clear that, in cimic's view, the main source of belief in the supernatural is the socio-cognitive (see above, 168-172).

${ }^{4}$ In this respect, Krešic expresses a similar idea when he writes that the notion of religion implies a special direction of the human spirit toward the superhuman, supernatural, transcendental, eternal, and absolute reality. The limited human will denies itself in order to be identified with the will of absolute existence, namely, God. with this identification or entrance into religious life, the battle between guilty "me" and a superior being ends. From that time on, one cannot say that he lives, but God lives in him (Andrija Krešic, Filozofija Religije [Zagreb:
} 
181

supernatural (unnatural) being is unnaturally realized human faith. 1

Holy Dimension

The application of the notion of the holy, according to ćimie, is not limited to certain previously defined realities; it surpasses the notion of the supernatural because it may designate some this-worldly phenomena. There are cases when the supernatural is not holy (for example, evil spirits or the devil). Since it is man who attributes holiness to certain aspects of his world, the criterion for the difference between holy and unholy is not in the objects themselves but in the individuals who define certain objects or certain acts of man as holy. ${ }^{2}$

Man bestows holiness on all those objects, beings, or processes which are somehow in close connection with some

Naprijed, 1981], 25). Bošnjak states that man's conversation with God, that is, with an imaginary being, is completely transformed in the rationalistic Marxist philosophy. Transcendence becomes immanence. Man finds in himself the content that he had transferred from himself to his created being. Deity is closed within the limits of the human being (Bošnjak, Filozofija i Krš́canstvo, 269-270).

${ }^{1}$ see Ćimić, Drama Ateizacije, 21.

${ }^{2}$ In trying to determine the essence of the notion "holy," ćimić gives an example of a farmer who was looking for water in his fields. He accidently pierced the ground with his knife and water sprung out. He immediately declared the place to be holy and offered sacrifices (idem, Drama Ateizacije, 21-22; see also Ateizam kao Povijesni Humanizam, 76). 
of his essential existential needs. 1 Wherever man feels imperilled, in nature or society, he consciously or unconsciously senses that he is essentially dependent on certain things and that their change or disappearance would cause his own uncertainty and fear. ${ }^{2}$ If man is not able to use valid experience or knowledge in any situation when he is in jeopardy, then he incarnates his powerless hope into the beings or situations that he declares to be holy. ${ }^{3}$ In

${ }^{1}$ see idem, "(Ne) Zaboravljeni Bog," 60. According to Pavićevic, wherever there is religion, there is also the experience of the holy or the designation of something as holy. The holy may be spirits, gods, places, time, words, or truth. Holy and profane are considered to be characteristics of totally opposite natures because their powers as well as their values are different. Pavicevic, however, differs from cimic in that he brings the religious concept of holy not into direct connection with the basic existential needs, but with the concept of experience of supernatural and other-worldly mystery (Pavicevic, Sociologija Religije, 13).

2It seems that the religious belief in the holy, in cimie's view, is caused by three different sources: the socio-economic, the socio-psychological, and the sociocognitive (see above, 160-171).

${ }^{3}$ Although Kerševan holds a very similar view of religion to that of cimic, he differs from him in his definition of the experience of the holy. Religion, for Kerševan, is always related only to human consciousness and is expressed through the experience of the holy. While for cimic the experience of the holy is one of the dimensions of religion, for Kersevan, it is the principal dimension of religion. Kerševan rejects the social and psychological dimensions of religion. Religion, for him, is a relatively autonomous phenomenon which is not related to human alienation, but to an experience of the infinite, supernatural, absolute, holy, and mysterious power (Kerševan, "Odnos Komunista Prema Religiji," 893-894). 
sum, holy is the opposite aspect of the human existential certainty. 1

\section{Ritual Dimension}

For ćimie, ritual as an objective and active form of religion (for instance, religious customs, prayers, and different religious gestures) represents an opposition to the tendency to transform religion into something too abstract and unattainable. ${ }^{2}$ The religious faith itself, by contrast to religious rituals, is only the acceptance of the supernatural as real. However, for the religious man, it is not enough that the supernatural exists; he must constantly be aware of its reality, and this awareness must have a certain influence on his social behavior. ${ }^{3}$

Religious rituals and customs, according to ćimic,, represent the means through which the believer influences that which exists outside and above himself. Faith itself

\section{1'Cimic, Drama Ateizacije, 22.}

2Idem, "(Ne)Zaboravljeni Bog," 60; see also Socijalisticko Društvo i Religija, 91; Drama Ateizacije, 2930; Ateizam kao Povijesni Humanizam, 77; "Religijski Praznici," Oko 6 (1978): 10. Kerševan holds that the structure of religion is basically determined by the reciprocal relationship between human beings and mystery. This relationship is maintained by different religious practices, particularly liturgy and practical moral obligations which institutionalize the relationship with the mystery (Kerševan, "Teorijski Model za Prouðavanje Religije kao Specificne Prakse," 732-750).

\section{3ćimic, Drama Ateizacije, 22; see also "structure} de la conscience religieuse dans les milieux rouraux et urbains," 173 . 
may become weak or even disappear if there is no support of rituals and customs. 1

For the religious man, especially for those who belong to the lower social levels, there is no major difference between that which is given as truly real and that which takes its source from his religious and mythological imagination. ${ }^{2}$ on the basis of his experiences in the real world, according to which one may accomplish certain effects (positive or negative) only by a series of certain actions, the religious man attempts, also by practicing certain strict and often hidden rituals, to incite the other-worldly powers to act in a positive or negative way. ${ }^{3}$

Religious customs and rituals are usually inherited from the past. They have not been lost because in the more and more complicated social conditions, religion (faith) has become more and more institutionalized and rituals have

${ }^{1}$ Ibid. In this respect, Pavicevic states that the religious rituals have their roots in the concept of the radical difference between holy and profane. There are rules and actions determined in advance which man must follow in his approach to that which is designated as holy. In addition, for communication with supernatural holy beings, there are specially designated people [priests or sorcerers] (Pavicevic, Sociologija Religije, 13).

2́cimic, Drama Ateizacije, 22.

${ }^{3}$ When cimic mentions negative actions of the otherworldly powers invoked by the believers in their rituals and customs, he thinks especially of the black and white magic practiced by many Indian tribes (ibid.). 
185

played a major role in that process. 1 In contemporary

attained primarily a suggestive-propagandistic

significance. 2

Moral Dimension

In the history of religion (i.e., theology), according to cimic, it was often thought that one of the basic reasons for the existence of religion is its importance for the moral behavior of man. ${ }^{3}$ Religion is considered by the believers to be a successful means in the fight against evil. If there were no religion, evil would increase. 4 Although theologians never succeeded in proving the existence of God, they almost always tried to justify the existence of religion by asserting that religion is the key postulate for the foundation of the universal moral imperative. 5

\footnotetext{
'It seems that, in ćimic's view, religious rituals, as well as religion itself, are caused by various sources mentioned above (see above, 154-173).

${ }^{2}$ See Ćimic, "(Ne) Zaboravljeni Bog," 60; Drama Ateizacije, 22; "structure de la conscience religieuse dans les milieux rouraux et urbains," 173.

3Idem, "structure de la conscience religieuse dans les milieux rouraux et urbains," 183; Drama Ateizacije, 23, 36; Dooma i Sloboda, 198; Socijalisticko Društvo i Religija, 48 ; "(Ne) Zaboravljeni Bog," 48; Covjek na Raskršcu, 119-128; Uvod u Marksizam, 89-90. For further information on the Marxist understanding of ethics, see sirovec, Ethik und Metaethik im Jugoslawischen Marxismus, 273-316.

${ }^{4}$ Ćimić, "Structure de la conscience religieuse dans les milieux rouraux et urbains," 183.

${ }^{5}$ Idem, Drama Ateizacije, 36.
} 
In modern Christianity, cimie states, there is a tendency to emphasize the need to establish a close relationship between man and deity. The real sign of the closeness of the believer to God is not external rituals but the consciousness of the believer, which is expressed in a most clear way in the practical-ethical area. ${ }^{1}$ Ethical practice is aimed toward the eschatological perspective of the last judgment, which in the religious pedagogy represents one of the most important themes. ${ }^{2}$ Thus, God is considered by the believers to be a guarantor of universal ethical norms and the only one who has the privilege to judge and condemn man for his sins. ${ }^{3}$ In the modern era,

${ }^{1}$ Idem, Covjek na Raskršču, 123.

${ }^{2}$ Krešic suggests in this respect that one of the basic sources of religiosity is the need of man for universal ethical norms. Man is longing for security which he usually does not find in his social environment. However, although religion offers man ethical definitions which claim to be universal, man remains motivated by the fear of God and His judgments (Kresic, Filozofija Religije, 24-25). Pavicevic writes that the transmission of moral norms from the real social life into the other-worldly, divine authority is not the result of the fantasy of some religious people but the expression of the real social needs for stability and security in social relations. There is no need to interpret the belief in the reward, punishment, or compensation in the future, other life only as a means for keeping the oppressed in the condition of passivity, but as an expression of human unreadiness to accept the final victory of evil, that is, the expression of the desire for the final victory of good (Pavicevic, Sociologija Religije, $27-30$ ).

${ }^{3}$ It is obvious that the main source of religion as a supply of moral definition is the socio-moral (see above, 172-174). 
the Church sees its chance for success in the world by being a more moral and less political force. ${ }^{1}$

\section{Summary}

cimic argues, contrary to dogmatic Marxism, that religious experience is a multi-dimensional phenomenon. Man is a limited being, with needs and desires which he often cannot satisfy and which transcend him. The supernatural is the creation of limited human nature as well as alienated social conditions. Thus, the supernatural is an attempt of religious man to break these limitations and conflicts by projecting human hopes into the transcendental heaven of faith.

Man attributes the concept of holiness to all objects, beings, or processes that are in close relation to his basic existential needs. He is afraid of uncertainty and of some possible negative changes in life, and for that reason he transforms his powerless hopes into the beings or objects that are changeless and holy.

Religious ritual represents the active side of religion. In our times, when many people are completely closed up within themselves, it has become clear that the collective values expressed in rituals are of great importance. Rituals help an individual to live in constant awareness of the existence of the holy kingdom and to keep

\footnotetext{
1ćimic, Drama Ateizacije, 36.
} 
alive and strengthen his or her faith in that kingdom. Metaphysical beliefs would hardly survive without the existence of the objects and customs which constantly remind the believer of the reality of the superior world.

Finally, one of the basic dimensions of religion is its importance for the moral behavior of man. For the believers, the establishment of a universal morality must find its fundamental postulate in religion. In that sense, religion is considered to be one of the powerful means for counteracting evil.

\section{Summary and Conclusion}

Ćimić criticizes and reconcepualizes the three basic dogmatic Marxist concepts of religion used in the context of socialist societies, namely, the enlightenmentrationalistic, spontaneous-economic, and administrative concepts. He argues that the enlightenment-rationalistic concept overemphasizes the cognitive aspect of man as an essential source of religion to the neglect of all others. The spontaneous-economic concept overlooks the complexity of the religious phenomenon, since a change in economic conditions may solve some but not all of the problems of man which stimulate the religious illusion. The use of any kind of administrative pressure upon the personality of a religious man deprives him of his consciousness and thus increases the need for religious zeal. Consequently, according to ćimic, the only valid concept of religion is 
the humanist-Marxist concept which asserts that every man must be allowed to act and interact freely with himself and with the society. The establishment of the social conditions which would make it possible for man to be a being of praxis is the only way to help him to resist the entrance into the world of religious necessity and fear.

cimic argues that man is alienated not only when the socio-economic conditions are oppressive, but always when he is prevented from being a being of praxis (i.e., when man loses one or several of his essential characteristics). In religion, man transforms his own being into another power which exists only in the imaginary world of his own consciousness and thus ceases to be a being of praxis. Irrational and uncontrollable socio-economic forces may be one of the factors which contribute to the intensification of religious feelings. But it represents only one possible source of the religious illusion. Man is also ready to accept religion whenever he suffers from isolation, loneliness, and professional communication in the society. In some cases, the insufficient intellectual perspective, the wonder about the unlimited nature of the cosmos, may result in religious belief. Or, for some people, religion is necessary because it provides man with moral definitions and thus serves as a means for the unburdening of guilty consciousness which is the result of unfortunate social conditions. Therefore, in opposition to dogmatic Marxist 
assertion that the socio-economic source is the principal cause of religion, ćimic contends the multiplicity and relative autonomy of the variety of sources of religion. The religious phenomenon is not simple but complex and has several dimensions. First, in religion, man attempts to break the limitations of his own being by projecting his hopes and desires onto a supernatural being. Second, in religion, man attributes the notion of holiness to those beings, processes, and objects which are in close relation to his existential needs. These holy and changeless beings and objects serve as a kind of guarantee, as opposed to man's unpredictable social situation. Third, religious rituals are means through which an individual lives in a constant awareness of the existence of the superior world. Finally, religion represents for the believers the fundamental postulate for universal morality and, thus, the powerful means for counteracting evil. Therefore, religion is not a simple phenomenon, as dogmatic Marxists contend, but rather complex and multi-faceted.

Having analyzed ćimićs reconceptualization of the dogmatic Marxist view of religion, we now turn to his own concept of religion which represents the core of his philosophy of religion. 
CHAPTER V

ĆIMIĆ'S CONCEPT OF RELIGION

This chapter analyzes Cimie's own concept of religion. Our focus, then, is on Cimie's foundational contributions to the humanist Marxist teaching on this subject. 1 First, we discuss his interpretation of the scope of Marx's critique of religion. This critique serves, in ćimic's philosophy of religion, as the theoretical ground ${ }^{2}$ for the introduction of three forms that the religious phenomenon takes: religion per se, religion as socio-historical fact, and religion as anthropopsychological structure. Second, we analyze ćimic's view of atheism as it relates to religion. Such an analysis is necessary in that, for ćimic, "socially transforming atheism" which is to be realized through and in the selfmanaging society, constitutes the climax of his reconceptualization of the dogmatic Marxist criticism of religion as well as the solution for the problem of human

\footnotetext{
'ćimic's own concept of religion, besides being influenced by the "humanist nucleus found in Marx's thought," is primarily the result of his personal research and understanding of the religious phenomenon (ćimic's letter, 1990; Ateizam kao Povijesni Humanizam, 66).

${ }^{2}$ Ibid., 61-66.
} 
alienation (including religious alienation).1 Third, our discussion also includes an analysis of the way in which ćimie's humanist-atheist position affects his major philosophical ideas, that is, his concept of God, man, ethics, history, and freedom. These ideas are analyzed because they allow a more complete as well as allencompassing understanding of Ćimil's reconceptualized view of religion and atheism. Furthermore, they provide a clearer perception of the role that both religion and atheism play in his thought as a whole. Finally, an analysis of ćimić's concept of self-management is undertaken. In his philosophy, self-management replaces an illusory, theoretical freedom with the establishment of social conditions that may help man to realize himself and become a being of praxis. ${ }^{2}$

\section{Cimic's Interpretation of the Limited scope of Marx's Critique of Reliqion}

As was mentioned above, ćimic's concept of religion has sprung up and is based on a humanist nucleus contained in Marx. ${ }^{3}$ Accordingly, even when Cimic presents his own view of religion, he feels the need to justify it by

\footnotetext{
${ }^{1}$ Idem, Drama Ateizacije, 207, 209-212.

${ }^{2}$ Idem, Religion and Self-Management, 132.

${ }^{3}$ See above, 107; Ćimic's letter, 1990.
} 
referring to the scope of Marx's critical thought about religion. ${ }^{1}$

Thus, Ćimie states that one of the undergirding ideas of Marx's thought is that the philosophical interpretation of reality is not sufficient for the achievement of radical change in the world. The process of man's liberation or de-alienation, including liberation from religion, cannot be exclusively located and exhausted on the theoretical level but must be complemented and even conditioned by the socio-economical level. ${ }^{2}$ The socioeconomic aspect of reality appears as one of the sources of man's cognition and as the place where man organizes his own forces as social forces. ${ }^{3}$ Accordingly, the critique of everything existing means that no segment of reality, including the socio-economic conditions in which man lives, can be excluded from that critical-creative analysis. 4

ćimic continues by saying that ideas and concepts, in Marx's thought, may become a real force, at the condition

\footnotetext{
IIdem, Ateizam kao Povijesni Humanizam, 61-66.

2Ibid., 61; "Marx's Critique of Religion and/or Atheism," 519-521; Socijalistiટko Društvo i Religija, 30-33; "Mogućnosti Marksističkog Pristupa Fenomenu Religije," 2829; see also Markovic, Humanizam i Dialektika, 130-133.

3ćimie, "Moguénosti Marksistickog Pristupa Fenomenu Religije," 29; see also Vranicki, "Socialism and the Problem of Alienation," 482 .

4 Ćimić, Ateizam kao Povijesni Humanizam, 61; see also Markovic, "Atheism Is Not Essential to Marxism; Critique of Religion Is," 530-531.
} 
that those ideas represent "the theoretical resume of the historical experience of humanity or humanity sublimated in the experience of theory."1 All socio-economic conditions which are in contradiction with these "universal" ideas are contrary to Marx's thought. ${ }^{2}$ Thus, he revealed the absurdity of bourgeois society by opposing to it the rational world of historical humanism. ${ }^{3}$ All his efforts were directed toward the elimination of the nonsensical situations in the real socio-economic conditions of the world. Consequently, the main goal of Marx's analysis of society was to demonstrate the existence of social situations in which man is deprived of any meaning for Iife. 4

When Marx analyzes the question of religion, he, in

1'́imic, Ateizam kao Povijesni Humanizam, 61; see also Petrovic, Marx in the Mid-Twentieth Century, 84 .

${ }^{2}$ See Ćimic, Ateizam kao povijesni Humanizam, 62; "Mogucnosti Marksistickog Pristupa Fenomenu Religije," 30 ; Socijalisticko Drustrvo i Reliqija, 30-31.

'In Cimic's philosophy, the term "historical humanism" is used synonymously with such terms as "humanness" and "man's genetic being." All three terms designate the essential characteristics of human beings, that is, consciousness, willful decision, and aim which are the result of the historical experience of humanity. The main goal of Marxism, in ćimic's view, is the creation of social conditions in which the realization of these essential human characteristics would become possible (idem, Ateizam kao Povijesni Humanizam, 61; "Marx's Critique of Religion and/or Atheism," 521; for further information, see Kerševan, "Atheism: Is It Essential to Marxism?" 504).

${ }^{4}$ ćimic, "Marx's critique of Religion and/or Atheism," 520; Ateizam kao Povijesni Humanizam, 62. 
Ćimie's view, takes into consideration only its direct dependence on the socio-historical context. Consequently, Marx does not approach religion in a theoretically abstract way, either positively or negatively. ${ }^{1}$ For him, religion is a social fact to be defined as self-alienation in the sense of being originated by the projection of man's personal powers and characteristics, that is, his essence on an otherworldly being. The source of religion as social fact is to be found in the unjust and unpredictable socioeconomic conditions. ${ }^{2}$ In addition, ćimie considers that his own view of religion as a historical fact is present in Marx's philosophy in an undeveloped fashion. The fact that Marx did not elaborate on it is considered by cimic to be an obvious deficiency in his critical thought about religion. 3 Cimic recognizes that the hypothesis of religion as a social-fact, that is, religion as alienation caused by oppressive socio-economic conditions, certainly proceeds

${ }^{1}$ Marx, in Ćimić's view, developed his critique of religion within the confines of the bourgeois society of the nineteenth century. Marx did not deal with religion as a separate phenomenon and because of that, one cannot speak of theory but of critique (ibid., 63; for further information, see Kuðinar, "Marksizam i Kritiči Pojam Religije," 44).

2̌́imić, Ateizam kao Povijesni Humanizam, 63.

${ }^{3}$ Religion as a historical fact, in ćimic's view, is to be defined as man's desire for self-transcendence and as a way to activate human powers. The source of religion as a historical fact is to be found in the nature of men, that is, in his psychological structure (for further information on this point, see below, 199-204, 208-211; Ćimić,

"Mogućnosti Marksistickog Pristupa Fenomenu Religije," 31). 
from Marx's thinking. Ćimic also recognizes that such hypothesis is so central to Marx's philosophy that, if abandoned, Marx's teachings are deprived of their basis. In addition, the concept of religion as alienation is not in contradiction, but as a complement to the thesis that religion is a special form of social practice. ${ }^{1}$ when Marx discusses the problem of alienation, he does not exclude science, philosophy, art, or religion from the sphere of possible alienation. Thus, for Marx, religion is not a priori predetermined as the only possible form of human alienation. All forms of consciousness in the capitalist society are, in Marx's view, potential forms of alienated consciousness. Only a later, dogmatic interpretation of Marx has branded religion as alienation while, at the same time, it has safeguarded the status of dealienated forms of consciousness for science, art, and philosophy. ${ }^{2}$ Thus,

${ }^{1}$ Cimic is arguing here against the thesis first formulated by Kerševan, according to which religion is not alienation but a special form of social practice. Kerśevan relies on the work of Althusser when he argues that religion is basically determined by the reciprocal relation between human beings and the experience of mystery. This relationship has its locus in religious practices and the religious community (liturgy and the church). cimic considers this thesis to be extremist because it negates the status of religion as an alienation (idem, "Mogućnosti Marksistickog Pristupa Fenomenu Religije," 32-33; Kerševan, "Neka Sporna Pitanja Marksisticke Teorije Religije," 980990; "Teorijski Model za ProuCavanje Religije kao Specificne Prakse," 732-759; "Atheism: Is It Essential to Marxism?" Journal of Ecumenical Studies 22 (1985): 503; "Savremeno Hrišcanstvo i Ideologija," 78-79).

2̌́imić, Ateizam kao Povijesni Humanizam, 64. 
theoretically, it is very important to start from the presupposition that religion is also alienation. If in certain socio-historical circumstances, the conditions for the existence of a class society are abolished and religion survives, the conclusion that religion is no longer to be considered as the expression of alienation will be difficult to avoid. Such a conclusion is in accordance with Marx's philosophy, because it is not religicn but the oppressive socio-economic conditions that are the focal point of Marx's critique. ${ }^{1}$

Consequently, according to ćimic, Marx did not elaborate on the positive aspects of religion which, adopting a different form, might survive in a classless society. Marx rather focused his analysis of religion to a criticism of the injustices found in a class society permeated with religious ideas. Thus, in cimic's view, Marx's primary goal was to overcome the horizon that conditioned such a society, and to abolish all alienating factors--the religious ones included. ${ }^{2}$

Contrary to dogmatic Marxism, cimic asserts that Marx's philosophy should be defined as historical humanism,

\footnotetext{
${ }^{1}$ See idem, Dogma i Sloboda, 132 ; Ateizam kao Povijesni Humanizam, 65; "Moguénosti Marksistickog Pristupa Fenomenu Religije," 32 .

${ }^{2}$ Idem, Ateizam kao Povijesni Humanizam, 65; "Marx's critique of Religion and/or Atheism," 521.
} 
not atheism. ${ }^{1}$ Marx's concept of religion ought to be understood within the limits provided by the framework of the philosophy of praxis rather than from the scattered fragments found in different places of his writings. ${ }^{2}$ No isolated element contained in Marx's critical philosophy should be considered as final and perfect. Since Marx's starting point is a radical "historical humanism," religion should be examined within this methodological framework. This implies that religion must be approached from within the contemporary context without any a priori label. Consequently, it is necessary to determine in what measure religion may be a barrier to positive changes in society as well as in what measure it may also be an inspiration for changing this world into a better place. 3

\section{Forms of Religious Phenomenon}

ćimic uses his interpretation of the limited scope of Marx's critique of religion as a basis for his own

\footnotetext{
'The term "historical humanism" refers here to "the theoretical resume of the historical experience of humanity" (see above, 194; Ćimic, "Mogućnosti Marksistiðkog Pristupa Fenomenu Religije," 30).

${ }^{2}$ Idem, Ateizam kao Povijesni Humanizam, 66; see also "Religija kao Istina Otudjenog Društva," Pregled 55 (1965): 15-32; "Višeznačnost Religijskog Fenomena i vidovi Njegove Interpretacije," Radovi FF Sarajevo 6 (1970-71): 487-503; "Marx's Critique of Religion and/or Atheism," 521.

${ }^{3}$ Idem, Ateizam kao Povijesni Humanizam, 66; "Mogućnosti Marksističkog Pristupa Fenomenu Religije," 33 ; "Religija i Savremeno Društvo," Kultura 13-14 (1971): 258316 .
} 
concept of religious phenomenon. He recognizes three forms of religious phenomenon and presents them as religion per se, religion as a socio-historical fact, and religion as anthropo-psychological structure. 1

\section{Religion Per se}

The religion per se form inaugurates the treatment of religion as a relatively autonomous phenomenon in respect to the socio-economic conditions. The main reason for the existence of religion per se is to be found in man's need to answer the so-called "last questions." Some of the most important "last questions" are the meaning of life, death, eschaton, the origin and existence of the universe, human "feeling of dependence," and "drive for happiness." 2 From the Marxist standpoint, these questions are legitimate. However, the religious and philosophical answers to these questions are always mediated, to a certain degree, by the historical, social, and cultural situation. ${ }^{3}$

In his attempts to answer the last questions of human existence, man, according to ćimic, tries to transcend

\footnotetext{
${ }^{1}$ The sequence of presentation of these three aspects of religion comes from the inner flow of cimic's thought itself (idem, Ateizam kao Povijesni Humanizam, 6776).

2Idem, "Marx's Critique of Religion and/or Atheism," 522; Drama Ateizacije, 200; Ateizam kao Povijesni Humanizam, 62, 67; "Mogućnosti Marksistiðkog Pristupa Fenomenu Religije," 33 .

${ }^{3}$ Ibid.
} 
his concrete being and situation. ${ }^{1}$ Religion is one of the forms of man's self-transcendence. Thus, very often, man is inspired by religion to abandon status quo and to take off into the transcendent, which appears to him as something prior to his historical situation, although, in reality, it grows out of his world. ${ }^{2}$ From the religious point of view, answers provided by human transcendence imply something radically different, ahistorical, hardly understandable by the human mind. From the Marxist point of view, however, these answers imply something different but, still, in many ways, dependent on the this-worldly. Consequently, religious answers provided by transcendence in reality are produced within the limits of the historical level and, therefore, they may be decoded on the basis of their sociohistorical roots. ${ }^{3}$

According to Feuerbach, man unlike animals, is a self-transcending being. Religion is one of man's means of

\footnotetext{
I'́imic uses the terms "transcendental,"

"metaphysical," and "transhistorical" to designate realities which exist outside of empirical and sensual and thus, cannot be subjected to empirical investigation (idem, Ateizam kao Povijesni Humanizam, 67).

${ }^{2}$ Ibid., 62,67 .

${ }^{3}$ It is not possible, in cimic's view, to elevate concrete historical situations, regardless of the perfection of their conditions, to the level of the metaphysical, transcendental, or transhistorical. It is also not possible to reduce some metaphysical, transcendental, supra-empirical realities to the socio-historical level, although the transcendental may be mediated by the historical (idem, Ateizam kao Povijesni Humanizam, 67; "Mogucnosti Marksistickog Pristupa Fenomenu Religije," 34).
} 
201

objectifying his own essence in ideal terms and then again making himself an object to this projected image of himself thus converting it into a subject. The cause of human selfprojection is to be found in the uncontrolled and unconscious exercise of human mind that with the aid of the science of anthropology, physiology, and psychology can be controlled. Marx embraced Feuerbach's idea of religion as being a form of human self-transcendence in which man projects an ideal image of himself and rejected the proposal that the source of religious transcendence is in human mind. In Marx's view, the socio-economic relations are the primary factors in creation of human ideas in general and religious transcendence in particular. cimic dismisses the notion of deterministic role of socio-economic conditions for the creation of human consciousness and argues that ontological structure of man and socio-economic conditions should be seen as two poles of the same reality which generates human self-transcendence. 1

From the human ontological standpoint, in cimic's view, religion per se, philosophy, and art have a common

${ }^{1}$ However, in some of Cimic's statements the socioeconomic conditions are given priority over anthropopsychological structure of man. This we see as an inconsistency (see below, 247-250; ćimić, Uvod u Marksizam, $36,45,47$; Hayden $V$. White, "Feuerbach, Ludwig Andreas," The Encyclopedia of Philosophy, 1967 ed., 3:191-192; Gorman, Neo-Marxism, 24). 
source, i.e., human nature. ${ }^{1}$ If the ontological

presuppositions of religion per se are abolished, then the presuppositions of philosophy and art would also disappear, because they are the same. All these forms of human spiritual activity, in different ways, satisfy man's enduring need to take off into the limitless space of transcendence in order to try to answer the last questions of his existence. ${ }^{2}$

It seems logical, Ćimic continues, to presuppose that some forms of religion will always be man's companion. Religion per se is not socio-economically determined, and its very existence expresses man's aspirations for the existence of order in the historical world. The socioeconomic situation determines only the form of the religious question, not the question itself.3 Thus, the form of

${ }^{1}$ Ćimic does not explain the real cause of existence of the urge for self-transcendence in human nature.

$$
\text { 2́́imic, Ateizam kao Povijesni Humanizam, 67; see }
$$
also Drama Ateizacije, 200.

${ }^{3}$ Idem, Ateizam kao Povijesni Humanizam, 68-70; "Moguénosti Marksistickog Pristupa Fenomenu Religije," 3435; Drama Ateizacije, 200-201; "Marx's Critique of Religion and/or Atheism," 521-522. Stankovic argues that the prime source of religion is not to be found in socio-economic conditions but in the general position of human beings in nature. Man's lack of wholeness and his limitations cannot be much improved. For stankovic, as for Kerševan, in opposition to ćimić, religion is not an alienating factor but an aid to complete oneself. Through religion, human beings receive what they do not have (Stankovic, "Covek i Religija," 650). 
religion will change in proportion with the changes of socio-economic circumstances. 1

ćimic's formulation of religion per se as a form of human "self-transcendence" caused by the "feeling of dependence" and "man's drive for happiness" denotes in his philosophy a firm, persistent, and resolute desire of human beings to create, different, that is, ideal existential conditions in which they live. ${ }^{2}$ In this point cimic comes close to the concept of religion developed by the liberal theology in the eighteenth and nineteenth century. Since human reason could no longer establish the existence of a transcendent God, as Kant argued, God become increasingly identified with the ideals and needs of human existence. Thus, for instance, in schleiermacher a "feeling of absolute dependence" became the source for talk about God. Kant and Ritschl developed their concept of God primarily on the basis of ethical values. Rudolf otto identified the feeling of the holy as the essentially religious element. This approach leaves somewhat ambiguous the reality of God. Although these philosophies of religion imply that there is one on whom we are absolutely dependent, one who is morally perfect, it seems that there was a tendency to avoid the

\footnotetext{
1'́́imić, Ateizam kao Povijesni Humanizam, 68-70. ${ }^{2}$ Ibid. , 65 .
} 
need for arguments for the objective reality of God. ${ }^{1}$ In addition, the assertion of historical-critical method that sitz im Leben produces, gives rise, and shapes religious ideas is similar with ćimićs contention that the socioeconomic situation determines the form of religion. 2

Religion as a SocioHistorical Fact

At this stage we turn to the concept of religion as a socio-historical fact, ${ }^{3}$ that is, religion which is the epiphenomenon of the unjust and oppressive social circumstances and which functions to perpetuate and reproduce that society. This form of religion, in cimic's view, represents the essence of Marx's criticism of

${ }^{1}$ see R. I. Saucy, "God, Doctrine of," Evangelical Dictionary of Theology (1984), 463; John B. Cobb, Jr., "God: God in Postbiblical Christianity," The Encyclopedia of Religion, 1987 ed., 6:23.

${ }^{2}$ See Dennis Nineham, "Historical Criticism," The Westminster Dictionary of Christian Theology (1983), 255258. The similarity between ćimic's philosophy of religion and liberal theologies' of the eighteenth and nineteenth centuries is not the prime concern of this study and, thus, may represent the object of some further investigation.

${ }^{3}$ It is puzzling why ćimic is not starting his own view of religion with this form of religious phenomenon since it is the closest to his Marxist roots. One of the possible answers may be his desire to interpret religion primarily as human self-transcendence caused by the "lastquestions" of human existence and thus distance himself from dogmatics. In addition, cimic uses the term "sociohistorical" in the identical sense as "socio-economic" with emphasis on the fact that every period of history has a particular socio-economic structure which differently influences the religious phenomenon (ćimić, "Marx's Critique of Religion and/or Atheism," 522; Drama Ateizacije, 201). 
religion. ${ }^{1}$ Marx was not interested in religion as "religiosity," 2 that is, man's constant desire to transcend himself resulting from historical experience of humanity. In addition, the fact that the "last questions" of one culture might not be the last, or might not be the questions at all, in another culture establishes Marx's claim that even the most subtle "last questions" are mediated by sociohistorical circumstances. For instance, the question of death belongs to the "last questions" in the Western European cultural tradition, while in the cultures of Asia questions of birth and beginning are "last questions." 3 Thus, it is in a certain socio-historical reality that one always is supposed to look for the roots of every critical thought about religion. 4

Marx, in cimićs view, challenges the validity of the "last questions" if they are situated outside of space and time. Besides that, if these questions do exist, then the unchangeable character of their hierarchy should be

\footnotetext{
IIbid.

${ }^{2}$ Idem, "Marx's Critique of Religion and/or Atheism," 522. Cंimic uses the term "religiosity" primarily in his discussion of religion as anthropo-psychological structure. However, it seems that the meaning he gives to this term may be equally applied to religion per se and religion as anthropo-psychological structure (see idem, Drama Ateizacije, 201).

${ }^{3}$ Idem, "Mogućnosti Marksistickog Pristupa Fenomenu Religije," 36; Ateizam kao Povijesni Humanizam, 70.

${ }^{4}$ Ibid.
} 
challenged. Marx, according to ćimic, constantly locates these questions in the changeable boundary between man and society cut of which grows the changeable criteria of values. 1 The change in socio-historical contradictions, out of which religion partially grows and lives, offers a possibility for the enlightenment of religious consciousness. Consequently, limited atheization (i.e., radical humanization) is possible to the extent to which religion is alienation. ${ }^{2}$

History demonstrates that religion, as a social phenomenon, behaves differently in different sociohistorical conditions. It is known that throughout history almost all forms of government have attempted to legitimize their power through the means of religion. In this privileged position, religion becomes more involved in the creation of culture (i.e., art, literature, music, philosophy) and of other forms of social life. By this mixing of religion with different social forms, religion imposes itself as an indispensable spiritual power. Very

1Ibid., 70-71; idem, "Mogućnosti Marksistickog Pristupa Fenomenu Religije," 36-37.

${ }^{2}$ Ibid. In opposition to ćimic, stankovic argues that religion is not alienation, since God is the idealized human or idealized human relations. Consequently, religion can contribute to betterment of humanity. The richer the divine-human relation, the better humanity becomes, because in religion people found an ideal, nonalienated person which is what they would like to be. In religion, people find perfection, completion, and the solution to the fundamental contradictions which in reality they are not able to solve (Stanković, "Čovek i Religija," 652). 
soon it becomes hard to differentiate between religion, culture, and political power. Inside religion itself there is a weakening of the need for salvation. This clearly demonstrates the fact that religion is changeable and different in its intensity in various socio-historical conditions.

Marx's assertion, cimic argues, that he brought the critique of religion to full completion ${ }^{2}$ should be understood conditionally. What is completed is the verbal critique which is supposed to be followed by the change of socio-economic circumstances. In that sense, the critique of society becomes, the paradigm for the critique of religion which is not outside or besides society but lives from its shortcomings. This is the way one ought to understand Marx's statement that the critique of religion, i.e., the critique of society, is the presupposition of every true critique. ${ }^{3}$

ćimic's notions of religion per se and religion as

${ }^{1}$ Ćimić, "Mogućnosti MarksistiCkog Pristupa Fenomenu Religije," 37; Ateizam kao Povijesni Humanizam, 71.

${ }^{2}$ Marx, "Criticism of Religion Is the Presupposition of All Criticism," 35 .

${ }^{3}$ Ćimic, Ateizam kao Povijesni Humanizam, 71; see also Marx, "Criticism of Religion Is the Presupposition of All Criticism," 35. In Dogma i Sloboda, 154-155, Ćimić writes that religion as social fact will exist as long as there are socio-economic conditions which force man to look for the solution to his problems in religion. However, religion as subjective fact will not disappear but will exist in a transformed form. 
socio-historical fact are general concepts in the sense that they may be applied to all human beings. At this point, we must turn our attention to an analysis of religion as anthropo-psychological structure. In cimic's view, this aspect of religion is seen as unique to each individual.1

Religion as Anthropo-

Psychological

Structure

When ćimic discusses his concept of religion as anthropo-psychological structure, he first establishes the difference between the "roots" and the "basis" of religion. He claims that the distinction between these two concepts is not only theoretical but was confirmed by the sociohistorical experience. The terms "basis" (baza) and "roots" (koreni) of religion are to be understood within cimićs concept of the "sources" (izvori) of religion. Thus, the term "sources" is a general term which includes both the "roots" and the "basis" of religion. "Roots" of religion are to be found in the oppressive social-economic conditions. The unjust social-economic conditions generate the form of religion as "class consciousness," which in one way or another participates in the sustaining of the oppressive social conditions. "Basis" for religion is to be found in the anthropo-psychological structure of man

\footnotetext{
${ }^{1}$ see below, 208-211.
} 
generating man's desire for self-transcendence. I

Accordingly, when the "roots" of religion are eliminated, religion loses its class-political character. 2 However, the foundational "basis" for the origination of religion as anthropo-psychological structure is given "from within itself (causa sui), in its own framework, by itself."3 The socio-economic situation, in ćimic's view, strongly influences individual consciousness in its acceptance or rejection of theistic or atheistic views. However, it does not influence the human mind directly but through the medium of personal anthropo-psychological structure which is unique for each person and which produces a special, individual kind of religiosity. In addition, human anthropo-psychological structure is able, to a certain extent, to resist the total influence of the social environment. 4

\footnotetext{
${ }^{1}$ ćimie, Ateizam kao Povijesni Humanizam, 75 ; "Mogućnosti Marksistiðkog Pristupa Fenomenu Relígije," 39.

${ }^{2}$ Religion which has its roots in the oppressive socio-economic conditions is religion that prevents man to become a being of praxis (idem, "Marx's Critique of Religion and/or Atheism," 523; Ateizam kao Povijesni Humanizam, 75).

${ }^{3}$ When ćimic speaks of religion which is given "from within itself," he makes an allusion to religion as historical fact which expresses man's desire to transcend himself and to attempt to answer the so-called "last questions" (ibid).

${ }^{4}$ Cimic states that lack of analysis of the anthropo-psychological basis of religion in Marx is a deficiency (idem, "Mogućnosti Marksistið̌kog Pristupa Fenomenu Religije," 39; Ateizam kao Povijesni Humanizam, 75).
} 
Consequently, religion as anthropo-psychological structure is influenced by socio-economic phenomena, but it is refracted through the mental structure of individuals. ${ }^{1}$ This is why when socio-economic conditions for the existence of religion are eliminated, the form of religion will be changed, but every form of individual religiosity will not disappear. ${ }^{2}$ Religiosity is an universal, psychological fact. Man is man because he will never lose the desire and need for self-transcendence. Whether the desire for religious transcendence will always exist, only the future will reveal. Even if religion can exist relatively autonomously without its own "roots," sustaining itself, it is hard to presume that it would not change so drastically that it would hardly resemble religion rooted in conditions in class society. Such religion will probably be "a poetic metaphor or a symbol of unflagging spirit."3 In addition, if religion were the individualized relation of man toward the world, or if religion did not have its social and,

${ }^{1}$ In this respect Kutinar writes that religion is an a priori given in human consciousness. Religion does appear in all historical periods; thus it is permanent. However, the future form of religion may be such that it cannot be labeled religion in the classical sense of the word (KuXinar, 56, 58).

${ }^{2}$ ćimič, "Mogućnosti Marksistickog Pristupa Fenomenu Religije," 39-40.

\footnotetext{
${ }^{3}$ See idem, "Marx's Critique of Religion and/or Atheism," 524 .
} 
211

especially, its political pretensions, it would be barely interesting for Marxism. ${ }^{1}$

\section{Summary}

Religion per se, in ćimic's view, is not a determined socio-economic situation and expresses man's desire for self-transcendence and his longing for social conditions better than what one finds in this world. However, religion per se may be influenced by the socioeconomic situation. Marxism is supposed to discover thisworldly sources of religion and try to eliminate them.

Religion as a socio-historical fact, for ćimić, is the focal point of Marx's criticism of religion. Marx was mainly interested in the elimination of religion as alienation, as "class consciousness," and not in religion as "religiosity." Here is the boundary of Marx's critique of religion. In addition, cimic contends that there is a possibility for the enlightenment of religious consciousness that may be accomplished by the change of socio-economic conditions out of which religion partially grows.

There are in the world different religions, different beliefs, and also different types of religiosity. This may be understood by the fact that every person has a peculiar mental composition by which he experiences the

\footnotetext{
${ }^{1}$ Idem, "Mogućnosti Marksistickog Pristupa Fenomenu Religije," 39-40; Ateizam kao Povijesni Humanizam, 76; see also Drama Ateizacije, 201-203; Dogma i Sloboda, 154-156.
} 
world. Thus, in the analysis of religion, not only socioeconomic factors are to be taken into account, as dogmatic Marxists argue, but also the constitutional elements of the human ontological structure which are less likely to undergo radical changes.

Once ćimic has formulated his view of different forms of religion, he is ready to suggest the solution for the negative, that is, alienating aspects of religious phenomenon. For him, the solution is to be found in the "socially transforming atheism" 1 which can be practically realized in self-management society.

\section{ćimic on Atheism and Religion}

We turn now to our second objective in this chapter, that is, to analyze cimic's view of atheism as it relates to religion. The concept of "socially transforming atheism" constitutes the core of cimic's philosophy of religion and, at the same time, represents the road of liberation from all historical, existential, and social limits which cause human alienation. 2 In addition, not only ćimie's concept of religion but also his view of atheism and his perspective in regard to the religion-atheism relationship represent an original contribution to the humanist Marxist reconceptualization of the dogmatic Marxist criticism of

\footnotetext{
IIdem, Drama Ateizacije, 62-63, 67.

${ }^{2}$ Ibid.
} 
religion. Once ćimié's idea of atheism is addressed, we describe the way in which his humanist atheism shapes basic issues of his philosophy which are intimately connected with his concept of religion. The examination of these main ideas contributes to a better understanding and a more comprehensive perception of cimic's view of both atheism and religion. Finally, an analysis of cimie's concept of selfmanagement is undertaken because it is the tool that will accomplish the practical realization of the "socially transforming atheism."1

\section{Atheism and Its Relationship}

to Religion

ćimic embraces the basic atheistic ideas of Feuerbach and Marx and uses them as presuppositions in his philosophical system. ${ }^{2}$ For instance, following Feuerbach, cimic argues that the idea of God is the projection of those essential-human characteristics without which man cannot live. ${ }^{3}$ Following Marx, cimić rejects the theoretical nature of Feuerbach's atheism and argues in favor of "socially transforming atheism."4 In addition, it should

\footnotetext{
${ }^{1}$ Ibid.

2Idem, "Religion and Church in Socialism," 94 ; Dogma i Sloboda, 122-123; Uvod u Marksizam, 86-87; McGovern, 16.

${ }^{3}$ Idem, Socijalističko Društvo i Reliaija, 26-27.

4'Ibid., 62; idem, "Religion and Church in Socialism," 94 .
} 
be noted that cimic's prime concern is the reconceptualization of the dogmatic Marxist view of atheism and not atheism as such. Consequently, he assumes the atheistic-philosophical foundations of Feuerbach and Marx and defines his concept of atheism as a reaction to dogmatism.1

Ćimic holds that there are various Marxist atheistic ideas of religion as well as numerous concepts of how to overcome religious dependence. ${ }^{2}$ some kinds of atheism, such as, accidental, spontaneous, and emotional, are nothing but a "disappointed religious consciousness," 3 and they characterize a dogmatic, deviant individual. 4 Accidental atheism holds that religion is the result of the activity of priests and the "remnant of the old [bourgeois] consciousness."5 In its confrontation with religion, it uses administrative methods. But, at the same time, it encourages the social conditions in which man is obliged to

\footnotetext{
${ }^{1}$ Idem, Drama Ateizacije, 62-63.

${ }^{2}$ Idem, "Religion and Self-Management," 125; see
} also Drama Ateizacije, 167-169; Covjek na Raskršcu, 105-110; "Religion and Church in Socialism," 80-85; "(Ne) Zaboravljeni Bog," 64-69; "Mogućnosti Marksistickog Pristuna Fenomenu Religije," 33; Doqma i Sloboda, 132; SocijalistiCko Društvo i Reliqija, 47-48; "Structure de la conscience religieuse dans les milieux rouraux and urbains," in conférence Internationale de Sociologie Religieuse, ed. Jacques Verscheure (Lille, France: Edition CISR, 1971), 177-178.

${ }^{3}$ Idem, Drama Ateizacije, 188 .

${ }^{4}$ Idem, Covjek na Raskršču, 105.

${ }^{5}$ Idem, Drama Ateizacije, 168. 
be religious in order to survive. ${ }^{1}$ The spontaneous type of atheism grows from "hollow optimism" and believes that religion will automatically disappear as the result of socio-economic development. All one is supposed to do is to wait patiently for that day. ${ }^{2}$ The emotional atheist feels that God does not exist, but he is not able to give rational arguments in support of his position. This atheist is often aggressive in the imposition of his attitude. He fights against God but not always for man. In his actions and his behavior, he is usually dogmatic. ${ }^{3}$ Marxist humanist atheism or "socially transforming atheism," on the other hand, leads to dynamic and optimistic activity resulting in social transformation. In addition, cimic asserts that "socially transforming atheism," because of its practical nature, should be defined as "theoretical agnosticism" and "a-theistic." 4

From the historical perspective, atheism represents an idea which has accompanied almost all liberation movements. During the French Revolution, for instance, a strong atheistic mood was an expression of the resistance against the church and all that it brought about at that

\footnotetext{
${ }^{1}$ Ibid.

${ }^{2}$ Ibid., 169.

${ }^{3}$ Idem, "Structure de la conscience religieuse dans les milieux rouraux and urbains," 177-178.

${ }^{4}$ Idem, Drama Ateizacije, 165; see also "Ateizam i Religija," Sociologija 12 (1970): 387-397.
} 
time, namely, exploitation and the disbelief in man. I This is where one should look for the roots of the often brutal protests by the people against church, priests, and rituals, as well as for the inhumanly demonstrated atheistic opposition to religion. ${ }^{2}$

Atheism that accompanied the Yugoslav and october Revolutions, despite their historical differences, manifested basically similar facts. Emotional atheists, besides those atheists who were able to expose rationally the ideological and moral weaknesses of the religious beliefs and system, being inspired by the revolutionary fervor, had expressed their opposition to the Church in a dogmatic anà uncompromising way. ${ }^{3}$

${ }^{1}$ see idem, "Religion and Church in Socialism," 80 ; Covjek na Raskršcu, 106; Reliqion and Self-Management, 125; "Ateizam u Teoriji i Praksi Savremenog Socijalizma," Gledista 5 (1964): 1143-1151.

2 In the case of the French Revolution, according to cimic, it was the French bourgeois class which wanted to change the world of that time fundamentally. The abandoning of the old medieval frameworks which prevented an independent development of new relations in the new society resulted in widespread atheism (see idem, Coviek na RaskršCu, 106).

${ }^{3}$ cimic writes that even today atheists in Yugoslavia feel atheism rather than penetrate its essence. Many of them are not able to explain their own spiritual position. A sociological study shows that theists in Yugoslavia also have similar problems and that most of them belong to the emotional type. cimic explains this phenomenon by saying that a Yugoslav reveals his sentiments, he is temperamental, often hasty and hot-tempered. The fact that he emotionally accepts values indicates the extensive possibilities (but only possibilities) that are hidden within himself for an intensive spiritual life. In order to cover the distance from undefined moods to the state of 
The one and only meaning of Marxist humanist atheism, for ćimic, must be found in the fight against the problems arising from the inhuman social conditions in which man lives. Marxist atheism must take into consideration man's freedom or slavery, as well as all that surrounds man and constitutes the essential content and meaning of his life. Consequently, the material freedom of man cannot be separated from his spiritual emancipation. ${ }^{1}$

cimic argues that whenever in the evolution of the socialist revolution the basis of human freedom was narrowed, it was accompanied by a remarkable intensification of religious awakening. For that reason, the power of atheism has always been and still is dependent upon broadening the scope of man's freedom, that is, man's

conscious awareness of them, one must pass through the arduous intellectual effort which implies the dialogue with the past, present, and future. Only then does the authentic existence of man become not a self-surrender to the spontaneity of living but a constant search for the meaning of life (see idem, "Religion and Church in Socialism," 81; Religion and Self-Management, 126 ; Coviek na Raskršču, 108).

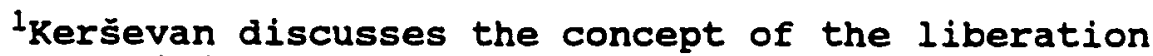
of man from religious alienation and states that in order to achieve that freedom, man must first be granted favorable social conditions: "The process of liberation from religion' can only be a matter for religious people themselves. Such liberation must be self-liberation, or it is not liberation at all but only a new form of submission. Under conditions in which religion is no longer a necessity or need, and in which it could perhaps vanish--although not necessarily--it is, together with atheism, a matter of human freedom" (Kerševan, "Atheism: Is It Essential to Marxism?" 504 ). 
spiritual as well as material freedom. 1 In the society which contends to be atheistic, but in which man is not free or has his freedom reduced to the minimum, atheism does not have a chance to succeed. ${ }^{2}$

When man lives in conditions of limited freedom, he may change the object of religion so that God is no longer in heaven but on earth. However, this does not change anything fundamentally, because religion remains religion regardless of the change of object. What is important is that man passes through the process of duplication in which he transfers his own powers to his stronger double. ${ }^{3}$ In other words, by transferring part of his unfulfilled self to some other power, earthly or heavenly, man alienates himself

1'́imić, Čoviek na Raskršču, 107.

${ }^{2}$ See idem, Socijalističko Društvo i Religija, 4748. When Kerševan writes about the relation between atheism and religion, he states: "Atheism, therefore, is neither the starting point, nor the basis, nor even the objective of Marxism. There is really no need to prove that it is not central to Marxism, to what Marxism is basically all about. This is clear even to Lenin, despite his sharp attitude toward religion. The struggle with religion had, in his view, primarily to be subordinated to the fight for socialism, to the class struggle. For him, the unity of the revolutionary struggle by the oppressed class in order to create a paradise on earth was more important than the unity of the proletarians' conceptions of a heavenly paradise" (Kerševan, "Atheism: Is It Essential to Marxism?" 504).

${ }^{3}$ See Ćimić, Dogma i Sloboda, 131-132; "Mogućnosti Marksistickog Pristupa Fenomenu Religije," 32 . 
219

and becomes impoverished to the extent to which he endows

some external entity with his own spiritual wealth.'

Freedom of conscience as well as freedom of social

action or practice are, in cimic's view, the most delicate

indicators of man's spiritual freedom which, at the same

time, represent the main characteristics of Marx's humanist

atheism. ${ }^{2}$ Atheism is only one of the dimensions of

${ }^{1}$ In this respect, Markovic expresses the similar idea when he writes that atheism which is nothing more than the negation of God and which postulates human existence through this negation has no meaning. What is needed is a social change that would permit all individuals to control their own social powers and to realize their humanity on earth instead of projecting them into heaven. Religion is an expression of suffering and a protest against it. Marx himself did not see religion as a vicious and parasitic form of consciousness but as something that consoles, justifies, explains everything, provides enthusiasm and moral sanctions, and creates an illusory happiness. Marx, for Markovie, did not call for an abolition of religion or for suppressing its institutions. He rather called for humanization of society, for emancipation of the oppressed, for real happiness of people, and for the elimination of the conditions which require religious illusions (Markovic, "Atheism Is Not Essential to Marxism; Critique of Religion Is," 529-531).

${ }^{2}$ Vereš does not agree with ćimic in his assessment of the essence of Marx's atheism. For him, Marx's atheism was incomplete, inconsistent, complex, ambivalent, and even contradictory, because radical atheistic positions are continuously intermingled with tolerance and humanistic openness. In the past century, this ambivalence has often been the cause of the uncertainty between the Marxist world and religious communities, that is, between the politics of "outstretched arms" and the politics of "clenched fists." Marxism is not to reject atheism, because it has the right to its own identity, but to humanize it by freeing it from totalitarian pretensions. Past experiences indicate that Marxist Promethean atheism was erroneously directed toward a struggle against God and religious communities instead of struggling against earthly gods which continue to rule. Moreover, Marxism has created a new hierarchy of its own gods in the countries in which it is in power (Tomo Veres, 
freedom; not one that is assumed, but one that results when a whole range of restrictions imposed on man, both his own and those at the broadest social level, are eliminated. ${ }^{1}$ Marxist humanist atheism is, thus, one aspect of the formation of human personality which implies his affirmation in the social life, in building up himself and his own criteria, in making his consciousness as sensitive as possible, and in sharpening his sense of responsibility. ${ }^{2}$ Consequently, humanist-Marxist atheism is a constitutive element of the socialist program which has as its goal the creation of an integral and complete personality. ${ }^{3}$

"The Ambivalence of Marx's Atheism," Journal of Economical Studies 22 [1985]: 559-560).

${ }^{1}$ see Ćimie, Coviek na Raskršču, 107; "Religion and Church in Socialism," 83; Religion and Self-Management, 127.

${ }^{2}$ Idem, Drama Ateizacije, 169. Ćimic states that in the focal point of the conflict between Marxist humanist atheism and the religious teachings are such concepts as new or old social relations, new rational conceptions or petrified conceptions, new psychological states or old psychic restraints, new moral judgments or antiquated norms (idem, Coviek na Raskršcu, 106).

${ }^{3}$ By taking the example of a Yugoslav self-managing community, cimic states that the building up of an integral personality is a very complex process. An integral personality may be achieved through the cooperation of men and institutions in the situation of a turmoil of old relations and new possibilities. Religion in Yugoslavia is the expression of a historical sense and new possibilities. For instance, the Catholic religion, which represents the most developed one on Yugoslav territory, contains the whole range of Yugoslav specific forms of belief ranging from pagan prejudices to ritual conventions. Thus, religion bears the imprint of the Yugoslav territory and people. Atheistic action, in accordance with this, cannot have that classical simplicity which it has in developed societies. (ibid., 107-108). 
221

Cimic suggests that by the simple abstract abolishment of the traditional form of religion, atheism does not win forever the battle for the spiritual contents and dimensions of man. ${ }^{1}$ If atheism is not a result of the favorable social conditions but an a priori imposed on man, if it is external and not internal, then it may originate a form of vacuum in the mind of people. ${ }^{2}$ Religion then fills that vacuum and presents itself to man as denoting the presence of the "whole" lying beyond the this-worldly as against the "partial" in the this-worldly. ${ }^{3}$

cimic also states that while "atheism is the expression of the demystified consciousness" which plays an important part in the shaping of human relations, religion is the "expression of perverted relations in alienated society."4 In addition, he observes that "atheism is a rational standpoint which bases its position on

${ }^{1}$ Ibid., 108; see also idem, Religion and SelfManagement, 128 .

${ }^{2}$ Ibid.

3The term "whole" denotes here the idea that religion does not deal only with this-worldly, empirical, "partial" reality, but is concerned also with the otherworldly, and thus, presents itself as a philosophy of the "whole" (idem, Coviek na Raskršcu, 108).

4Idem, "Religion and Church in Socialism," 85. 
scientifically-proven facts about the universe, history, society, and man."1

The question of what atheism is, in ćimic's view, cannot be separated from the question of what religion is because they have the same ontological presuppositions and are "placed in the metaphysical nature of man, in the curiosity of human being, and in the admiration of the wonder of Being."2 Historically speaking, atheism has accompanied religion throughout history as its shadow. ${ }^{3}$ Consequently, atheism brings its own existence to question and necessarily denies itself to the extent to which it successfully denies religion because religion is a hypothesis of atheism. 4

on the basis of empirical evidences that cimic obtained in his study of religion in Yugoslav society, he developed the following typology of religious or atheistic motivation:

The first category of people are those who are religious for aesthetic reasons. They are in love with nature, they are taken by its rhythm and see nothing but

\footnotetext{
'Ibid. In my view, Ćimic's concept of atheism as related to religion is ambiguous and inconsistent (for the evaluation of that inconsistency, see below, 253-257).

2 Idem, Drama Ateizacije, 62.

3Idem, "Religion and Church in Socialism," 85; Religion and Self-Management, 128 ; Čoviek na Raskršcu, 109.

${ }^{4}$ Idem, "Religion and Church in Socialism," 85
} 
nature's metaphysical, unperishable side. However, when this category of people realize that religion does not contain sufficiently adequate and broad possibilities for self-development, they turn away from religion and find their proper medium in art and philosophy because, in this case, art and philosophy represent a form of sublimized religion.

The second category of people are those who are usually rational thinkers and who become religious when they discover something irrational at the boundary of rationality, something that cannot be included in the rational. Comparable to this group of theists are those who cannot resolve religiosity on an intellectual level. They usually replace one type of religiosity with another. For instance, they may replace their religiosity by a belief in science. They usually follow this path because the structure of their reasoning is not able to critically relate to science.

The third category of people are those who are not impressed by nature nor interested in the rational reasoning but possess a keen moral imagination. They are worried by the moral crises in the world and see in God the only origin of morality which is not endangered. Thus religion for them is an oasis of morality. Atheists who possess the same structure of reasoning see in God an alienated mediator, and 
for that reason they remove Him as a barrier to humanization.

The last category of people are those who are indifferent toward their situation and their rational solutions. They do not react to any rational or moral crises. Their mental structures are the result of the ruthless social violence of the modern world. It is the modern culture which makes man devoid even of the need to think. ${ }^{1}$

\section{ćimićs Main Philosophical} Ideas

At this point we turn to the analysis of the way Ćimié's humanist-atheism affects his key philosophical ideas. Furthermore, without these main ideas it is not possible to have a complete and comprehensive perception as well as fair evaluation of his concept of atheism as related to religion. We discuss ćimie's concept of God, man, history, ethics, and freedom because they seem to be the most relevant for the better understanding of his reconceptualized concept of religion and atheism.

God

God, for ćimić, is not a real entity but rather an idea produced by the socially conditioned projection that alienated human beings make of their best qualities. In

\footnotetext{
'Ibid., 85; idem, Religion and Self-Management, 129-130.
} 
other terms, God is deified man. Man bestows upon God those characteristics without which he cannot exist. ${ }^{1}$ God is perfect because man is finite and limited. Unable to become God, man creates God in order to satisfy his thirst for perfection and order in the this-worldly sphere. 2

Contrary to dogmatic Marxists, cimic argues that God's existence cannot be denied by the use of scientific methods. 3 The fact that the existence of God cannot be proven scientifically implies that it also cannot be denounced. Whenever science attempts to speak of its own presuppositions, it steps unintentionally into the field of philosophy.4 Theological and philosophical speculation on the existence of God remain outside the competence of science, since to each "no" it is possible to oppose at least one "yes." Consequently, both theists and atheists can never be fully comforted by the results of philosophical

\footnotetext{
The influence of Feuerbach's concept of religion as "projection" of man's desires and needs on cimic's view of God is obvious (see McGovern, 16; Ćimic, Socijalisticko Društvo i Religija, 26-27; see also Dogma i Sloboda, 122123; Uvod u Marksizam, 86-87; Coviek na Raskršču, 104; Drama Ateizacije, 44-45).

${ }^{2}$ Idem, Socijalistiłko Društvo i Religija, 27 ; see also Ateizam kao Povijesni Humanizam, 15, 79.

${ }^{3}$ see above, 131-134.

${ }^{4}$ According to Ćimić, science is a human activity which deals with the area of the empirical, i.e., historical, social, natural, and psychological. Religion and philosophy, on the other hand, deal with the suprahistorical, other-worldly, and metaphysical (see above, 131134; Ćimić, Drama Ateizacije, 44, 203-205; Dogma i sloboda, 127-133.
} 
argumentation. The question of God's existence (i.e., the idea of transcendence as such) remains an area for man's spiritual exercises and a chance for the constant relocation of the boundaries of human knowledge. 1 In addition, if people believe in God, then a Marxist wants to know what has caused that belief in the society and what are the consequences of that belief for their individual and social ife. ${ }^{2}$

ćimić's view of God reconceptualizes the dogmatic Marxist criticism of religion by denying the possibility of the eradication of religion through the development and use of scientific knowledge. This is why religious phenomenon will probably always exist and will remain an area of human spiritual exercise.

Man

Ćimic's assumption that God does not exist as a real entity determines his contention that man is a selfsufficient being. Man, in his view, is the product of

\footnotetext{
IIbid.

${ }^{2}$ See idem, "Mogućnosti Marksistiðkog Pristupa Fenomenu Religije," 42; Drama Ateizacije, 47; Ateizam kao Povijesni Humanizam, 79-83. In this respect, Gardavsky states that although the concept of God may sometimes simply reflect the existing world, a Marxist knows that God can also represent a direct call for a socially responsible decision to act. In this sense, a Marxist is interested in the concept of God not so much for what it says about God but for what it says about human beings. The concept of God loses its dreamlike quality and challenges man to action (Gardavsky, God Is Not Quite Dead, 200).
} 
nature and history. He is also part of nature being influenced by his surroundings and by influencing it. 1 As the product of nature, man makes efforts to satisfy his basic physical needs. But, as a human being, man has specific needs which increase in proportion to the increase of his human possibilities. ${ }^{2}$

Contrary to dogmatic Marxist determinism, cimić maintains that man is above all a being of praxis. It implies that he is the wholeness of his multi-nimensional existence, including the elements of consciousness, goal, and willful decision. In other words, praxis is the activity of total man in which he expresses his creative, imaginative, inventive, adventurous being, a being which has the possibility to be always different, new, and unpredictable. ${ }^{3}$

Human beings, ćimic continues, in view of the structures of their nature, essentially transcend the concrete socio-historical situation. ${ }^{4}$ There are elements in the structure of human nature which may be considered as

IĆimić, Coviek na Raskršču, 90-91; see also Drama Ateizacije, 104-105; "Religion and Church in Socialism," 81; Ateizam kao Povijesni Humanizam, 28; "Mogućnosti Marksističkog Pristupa Fenomenu Religije," 30; Uvod u Marksizam, 31 .

2 Idem, Čovjek na Raskršču, 90-91.

3Idem, Drama Ateizacije, 178.

${ }^{4}$ Ibid. , 104-105. 
essential and universal, ${ }^{1}$ but which are always expressed in and influenced by the concrete cultural-historical context. ${ }^{2}$

In the contemporary world which is rapidly changing its face under the influence of the scientific and technical revolution, man is becoming more and more alienated. He is losing one or more characteristics of his essential (genetic) being which distinguish him from everything else. ${ }^{3}$ In order to overcome alienation, it is necessary to remove irrational social conditions and to create a world in which man will be able to realize his essence. 4 If human life is determined by certain laws and principles which are the expression of humanity's historical experience (i.e., its essence), then human life has meaning in spite of all difficulties, and it is worth being lived. 5

The fact that there are problems in human existence which cannot be removed by any social change, such as death, sickness, and different psychological problems, implies that "socially transforming atheism" has its limits and that

${ }^{1}$ See above, 193-194.

2́cimic, Ateizam kao Povijesni Humanizam, 62, 61.

${ }^{3}$ Idem, Coviek na Raskršću, 11-17. For further information on man's "essential being," see above, 158 .

"The term "human essence" is used here synonymously with the term "praxis" which includes human willful decision, purpose, and consciousness (Ćimić, Drama Ateizacije, 184).

${ }^{5}$ Ibid. 
these problems will always be solved in the transformed form of religion as well as in other forms of man's spiritual activity or in nihilism. ${ }^{1}$ It also means that religion will probably always be man's companion.

Ethics

Cimic contends that God is not the necessary foundation of good. It is society that fosters good or bad behavior since people are inherently neither good nor bad. ${ }^{2}$ Society should stimulate the moral behavior of individuals, not by demanding moral behavior but by providing the best socio-economic environment for moral activity. The task of morality is to uphold certain norms, to sanction unequal relations among people as well as to create a society which would obliterate the need for either religious or atheistic morality. 3

Christian morality, in cimic's view, ought to be criticized because, with some exceptions, it is inclined to

1'Ibid. Bošnjak, contrary to cimić, denies the existence of any objective meaning for humanity. The only meaning for him is to be found in the development of each person as a true human being (Bošnjak, Filozofija i Kršćanstvo, 386).

2'́imic, Coviek na Raskršću, 128 ; see also Uvod u Marksizam, 89-92; "Structure de la conscience religieuse dans les milieux rouraux et urbains," 183; Dogma i sloboda, 198; Mojzes, Christian-Marxist Dialogue in Eastern Europe, 309-310.

${ }^{3}$ Ćimić argues that ethical norms should not be something imposed from outside but an intimate way of behavior (see above, 105; Ćimic, Covjek na Raskršcu, 132133; Uvod u Marksizam, 91). 
advocate merely abstinence from evil rather than an active opposition to it. Religious morality also fosters a feeling of dependence, passivity, and the absence of a direct affirmation of humanism. ${ }^{1}$

The basis of atheistic morality is in the human being's ability for compassion without self-interest and in the instinct for the preservation of the species. ${ }^{2}$ An atheist should love other people and feel responsible for them. ${ }^{3}$ Although human conscience is a dependable indicator of good and bad actions, of what we do and what we ought to do, it is praxis that determines the truth. 4 The ideal society is the one in which man, as a being of possibilities, would be able to express himself freely, and in which old forms of Christian or atheist morality would be

\footnotetext{
${ }^{1}$ Idem, Coviek na Raskršču, 123-126; Dogma i Sloboda, 198 .

${ }^{2}$ cimic argues that atheist morality is in contrast with the ethics of religious people whose moral consciousness is usually directed toward the eschatological perspective of the last judgment (idem, covjek na Raskršcu, 123).
}

${ }^{3}$ Heller expresses the similar idea as Cimie when he states that Christian and Marxist ethics are based on different ontological principles; namely, Christian ethics is based on the concept of transcendence, while Marxist ethics is based on immanence. It is not true that if there is no God, all is allowed. If there is no God, one's responsibility toward other human beings is increased (Agnes Heller, "Marxistiche Ethik, Christliche und Gesellschaftliche Revolution," International Dialog Zeitschrift 5 [1972]: 70-78).

${ }^{4}$ Ćimic, Čoviek na Raskršcuu, 127 ; Uvod u Marksizam, 91; Drama Ateizacije, 46 . 
transcended, that is, left behind. 1

Ćimićs concept of ethics implies that society should stimulate moral behavior, not by using administrative measures (dogmatic approach), but by providing the best possible socio-economic enviromment, that is, by establishing the self-managing society. He also argues in favor of the elimination of both atheistic and Christian ethical norms in order to make it possible for man to become a being of praxis.

History

History, in Cimic's view, is the medium in which the life of society takes place. ${ }^{2}$ His assumption that God does not exist as a real entity leads him to contend that the creator of history is man himself who, in communion with other men, establishes a system of laws which regulate their mutual social relations. However, these laws governing social relations are historically conditioned and historically changing. From the first class society to the socialist society, there was a sequence of revolutions caused by the conflict of class interests. This represents the moving force and the internal dialectic of historical development. 3

\footnotetext{
${ }^{1}$ Idem, Covjek na Raskršcu, 133.

2 Ibid., 15.

3Idem, Uvod u Marksizam, 111-112; Coviek na Raskršču, 16 .
} 
The being of society is, in some of its aspects, historically predetermined. When man comes into existence, he finds, against his will, social relations already in operation which are dependent on the level of development of the production forces and production relations in the concrete historical society. ${ }^{1}$ But this may lead to fatalism, that is, to the necessary relations which are independent of human will. Because of that cimic argues that although man, when he biologically comes into existence, finds certain socio-economic relations, he can change them, together with other men, but only to a certain degree. In other words, man may realize the sum of his human potentials, but he never trespasses "the possible historical frame."2

Ćimie emphasizes also that Marx considered the law of dialectical development of history to be historically relative. This means that although socio-economic circumstances are of prime importance, they do not have the same, deterministic intensity of influence on the other phenomena within the society. In addition, the non-economic

\footnotetext{
IIdem, Uvod u Marksizam, 112.

2'imic uses the term "the possible historical frame" to express the fact that the laws of material base of society determine human beings to a certain degree (ibid.; see also idem, covjek na Raskršcu, 16).
} 
phenomena in society, such as human beings, can have a strong influence on the economic processes. 1

The main implication of ćimic's humanist-atheist concept of history is his assertion that the influence of the substructure on the superstructure is greater in the society which is less developed. Because of that, all efforts of man should be directed toward the establishment of a society in which the law of the dialectical development of history would not be valid any more and in which the economic aspect of society, or any other, would not play the decisive role, but in which man would be the ultimate criterion. 2 Consequently, only then could the problem of religion as alienation be solved.

Freedom

$$
\text { Freedom, in cimić's view, may be understood as }
$$

"self-determination, that is, as relatively successful action in an objectively given situation in which the actor-individual or social group--may act according to some

\footnotetext{
1'́imic approvingly quotes Lukacs embracing his category of totality which is the carrier of the revolutionary principle and in which individual elements must be seen in the light of the whole. He also insists on the dialectical relation between base and superstructure. However, it seems that the economic factor plays the essential role in cimic's philosophical system at the expense of other factors within the totality of reality (idem, Uvod u Marksizam, 50, 69-72).

${ }^{2}$ Ibid. , 112-113.
} 
personal internal structures." 1 Freedom is potentially present in every individual and represents the precondition for creativity. ${ }^{2}$

Freedom consists of the possibility of changing the limits of man imposed by nature. In addition, freedom is not only the overcoming of the outside objective situation, but the overcoming of man's internal impulses, that is, a change of character. ${ }^{3}$ Internal impulses, such as desire for power or for having material goods, are also likely to alienate man. ${ }^{4}$ If there were no possibility for surpassing objective and subjective impulses, man would be really determined and formed by all that he has received from a certain socio-historical environment. Free is that man who successfully determines himself, that is, who enters into the determinist relationship, and who attempts within this relationship to keep or develop, independently from any

\footnotetext{
IIbid., 47.

${ }^{2}$ Ibid., 47-48.

${ }^{3}$ Idem, Coviek na Raskršcu, 18.

${ }^{4}$ Here cimie comes very close with the Christian idea of the need to change man's internal, sinful tendencies. Kuczynsky argues in the same line of thought as ćimic when he states that Marxists and Christians should collaborate in the face of the threat by mass culture which devastates creativity and freedom and creates mediocre, selfish, nonreflexive individuals who are satisfied with the trivial values of everyday existence. Both Christianity and Marxism condemn hedonism and the sentimental pragmatism of mass culture (Janusz Kuczynski, "The Sense of Existence: Creativity and Community," Dialectics and Humanism 5 [1978]: 190-173).
} 
235

supernatural being, his own structure from the position of his personal goals.'

The basic criterion for human freedom, according to cimic, should be located in the possibility of the realization of man's creative abilities through work. Thus, freedom, contrary to dogmatic Marxist determinism, cannot be reduced to the conscious acceptance of certain social norms. within the conditions developed by a socialist self-managing society, only the man who actively participates in the creation of the new social values is free. ${ }^{2}$

The criticism of religion as a form of spiritual bondage is closely related to the question of human freedom. In cimic's view, only the criticism of the erratic socioeconomic conditions as implied in the concept of "socially transforming atheism" constitute a justifiable critique. ${ }^{3}$

Ćimiés humanist-atheist concepts of God, man, history, ethics, and freedom are permeated with a deep concern for the well being and freedom of man. This includes the liberation from all estrangement including religion (to the extent to which it represents an alienating force). The climax of that concern is found in cimic's view of the self-management society which is the tool that will

\footnotetext{
1'́́imic, Uvod u Marksizam, 48.

2 Idem, Coviek na Raskršču, 19.

${ }^{3}$ Idem, Religion and Self-Management, 137-138.
} 
accomplish the practical realization of the "socially transforming atheism."

\section{Self-Management}

Self-management, ${ }^{1}$ in ćimic's view, is an important method in the fight against alienation as well as the stimulant to the process of humanization. ${ }^{2}$ The basic premise of the concept of self-management is that all "that is" must be reconciled with all "that should be." 3 The goal of self-management is to strengthen human beings' social relationships through the process of uniting their economic, moral, political, and psychic dimensions.4 The economic dimension of self-management is expressed in reuniting human work with its own owner. The associated producers are in possession of their own power and the products of their work. 5 The moral-psychic dimension of self-management is to be seen in the fact that

\footnotetext{
1The term "self-management," in Cimić's view, includes both the society and the individual. It implies that the individual and society are so interwoven that the more society is molded in a humane way the more it is hard to delineate between the two (ćimic's letter, 1990).

2Idem, Religion and Self-Management, 131.

${ }^{3}$ See idem, "Religion and Church in Socialism," 97101; Socijalisticko Društvo i Religija, 49-71; Drama Ateizacije, 104-109; Dogma i Sloboda, 124; Coviek na Raskršcu, 110-115; Uvod u Marksizam, 97-100; Religion and Self-Management, 132 .

4Idem, Covjek na Raskršču, 112; "Religija u Samoupravljačkom Društvu," Iskustva 2 (1972): 9-24.

5Idem, Čoviek na Raskršcuu, 112.
} 
the more man is able to rely on his own powers, the more he becomes responsible before himself and society. The more intensive and lasting human engagement stimulates the use of one's own moral criteria. Self-management presupposes that man relates less and less to other men as an object and more and more as a subject. Self-management also stimulates man's cognitive activity. Man is encouraged to think, not to arrive at final conclusions. ${ }^{1}$

Cimic continues by arguing that through selfmanagement activity, which is totally opposite to centralized power in communist countries, man raises himself to the level of the creator of his own destiny. Since it is man himself who decides on the distribution of that which he has produced, he gains confidence in the power of his own actions combined with the action of others. Thus, selfmanagement means free, creative participation in the shaping of present reality as opposed to alienation which generates the feeling of helplessness, and the need to escape to the world of illusions. ${ }^{2}$

Furthermore, self-management generates the intensification of the process of democratization of society in general. When there is more freedom, men not only become more powerful and responsible, but they establish close

${ }^{1}$ Idem, Religion and Self-Management, 132 ; "Religion and Church in Socialism," 99; Drama Ateizacije, 106-107.

2Ibid., 107. 
relationships in order to more successfully manage things, not people. Man's creative action enriches society. society returns to him the fruits of his work, and at the same time broadens the framework of his own individual action. The gap between individual and social interests increasingly diminishes to the point that social interests increasingly become man's personal concern.'

If self-management is both the process through which a genuine fulfillment of human nature and the intensification of the process of democratization of society in general may be achieved, its contribution in the overcoming of alienation can be clearly perceived. ${ }^{2}$ selfmanagement does not allow an external coercion by eliminating every possibility for any institution or group of people to misuse the social power entrusted to them. Here, in Cimic's view, the basic relationship between selfmanagement and "traditional religion" can be found. ${ }^{3}$ This relationship is of an inverse nature in the sense that the development of the process of self-management weakens the

${ }^{1}$ Ćimic makes clear that his theoretical model of socialist self-management is in many ways different and opposed to the reality of Yugoslav self-management society. He states that it has attempted to create a model, and precisely because it is a model it must be sufficiently generalized and simplified (idem, Coviek na Raskršcu, 113; Religion and Self-Management, 130).

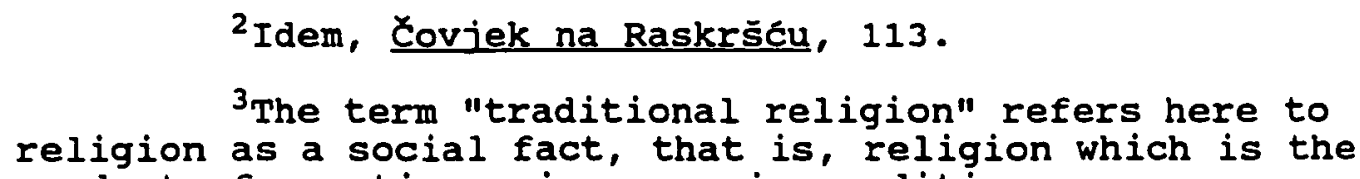
religion as a social fact, that is, religion which is the product of erratic socio-economic conditions. 
traditional religion or even causes it to disappear. ${ }^{1}$ However, socialist self-management means, according to cimic, the overcoming of given erratic social conditions, not in order that man might free himself from religion, but rather in order that he might live a life adequate to his human essential nature. ${ }^{2}$ In addition, cimic suggests that the most important dialogue between believers and nonbelievers is in the actual process of self-management and not between the leaders of the church and state. ${ }^{3}$

\section{Summary}

The focal point and major concern of Marx's philosophy, in cimic's view, is not religion but the cruel and erratic social reality created by the socio-economic conditions of capitalism. Consequently, cimic is of the opinion that Marx's concept of religion is to be understood

\footnotetext{
"'́imie, "Religion and Church in Socialism," 98 ; see also Drama Ateizacije, 107; Religion and Self-Management, 133.

${ }^{2}$ Cimic writes that on the basis of empirical research that he had done in Yugoslavia among Catholic, orthodox, and Moslem populations, he found that selfmanagement practice has exercised a strong impact on the intensity of rejection of traditional religion. In practicing socialist self-management, people became convinced that it represents the negation of social coercion and social powers which rule over human beings as an indisputable, almost natural force. Since religious consciousness as well as other alienated forms of consciousness appear in situations of fear and uncertainty, self-management contributes to the decrease of interest for the traditional religion (ibid., 133-136).

${ }^{3}$ Idem, "Politiðko i Idejno suołavanje s Religijskim Fenomenom," 186-187.
} 
within the framework of the philosophy of praxis and not from the scattered statements taken out of context from his works as dogmatic Marxists usually do.

on the basis of these considerations cimic has formulated his view of three forms that religious phenomenon takes. First, religion per se is a relatively autonomous phenomenon because it is not determined by the concrete socio-economic conditions. It is an expression of human beings' natural desire for self-transcendence and for surmounting the concrete erratic socio-historical situation. secondly, religion as a socio-historical fact has its source in the unpredictable and unjust socio-historical conditions of society. Marx's critique of religion was directed against this form of religion, that is, religion which is the epiphenomenon of the bourgeois society and which functions to perpetuate that society. Thus, since this form of religion arises from the shortcomings of the society, the critique of the society becomes the paradigm for the critique of religion. Thirdly, the fact that there are different religions in the world demonstrates that every person has a unique mental composition by which he expresses his religiosity. Thus, the expression of religious feelings pass through certain levels of human psychological structures which are unique for each person. In the second part of this chapter we have analyzed ćimić's concept of atheism as it is related to religion, his 
major philosophical ideas, and his view of self-management. The climax of cimic's concern for human freedom is found in his concept of atheism which is to be realized in the selfmanagement society. The goal of the "socially transforming atheism" is to create such social conditions in which both theists and atheists can truly fulfill themselves. However, when atheism successfully destroys religion, it paradoxically brings about its own death.

In order to have an all-inclusive understanding of cimić's concept of atheism as related to religion, it was necessary to analyze his main philosophical ideas. Thus, he argues that God does not have real existence but is the result of man's imagination. Man is the product of nature and history. However, man is primarily a being of praxis and, thus, the creator of his world. Man can change the world only within the limits provided by the objective laws of historical development. Man is free only to the extent to which he is able to successfully satisfy his own human needs within the outside deterministic reality.

cimic's concept of self-managing society expresses the idea of possibility for human beings to realize their freedom. In the self-managing society man assumes the role of the creator of his own destiny. In addition, freedom, that is, the establishment of self-managing conditions in which man would be able to become a being of praxis, is the 
242

best means to fight man's illusory escape from this world which is manifested in religious experience.

Having analyzed ćimie's concept of religion, it is now our intention to evaluate it from the dogmatic Marxist standpoint, from the perspective of the inner consistency of his philosophical system, and from the Christian-theistic viewpoint. 
CHAPTER VI

\title{
EVALUATION OF ĆIMIĆ'S CONTRIBUTION TO THE CONCEPT OF RELIGION
}

\begin{abstract}
Having described and analyzed C̈imic's humanistMarxist concept of religion, it is now our intention to evaluate it from three perspectives: that of dogmatic Marxism, that of inner consistency of his philosophical system, and that of Christian-theism. ${ }^{1}$

The dogmatic Marxist concept of religion is used as a point of reference for the evaluation of cimic's view of religion because his philosophy in general, and especially his concept of religion, represent a reconceptualized response to and criticism of it. ${ }^{2}$ cimic states: "There is no similarity whatsoever between the dogmatic Marxist approach to religion and mine since I constantly relate

${ }^{1}$ We use the term "Christian-theistic" in the sense of a belief in the existence of God, that is, in opposition to "atheism"--the term for the denial of the existence of God. In addition, we presuppose that the Bible represents the source of authority for Christians and thus the terms "biblical-theistic" or simply "biblical" are used interchangeably with "Christian-theistic" (see John s. Feinberg, "Theism," Evangelical Dictionary of Theology [1984], 1080).

25ee Ćimić, Drama Ateizacije, 11; Doqma i sloboda, 5-12, 40-42, 101-103, 104-110; Letter, May 22, 1989.
\end{abstract}


myself critically, whether explicitly or implicitly, to it."I However, although ćimic has made important contributions to humanist Marxism, the question can be raised whether there are still elements in his philosophy which are in many ways identical with the dogmatic Marxist concept of religion?

Evaluation of the inner consistency of Cimic's philosophical system is not the main trust of this study. His philosophical system, however, serves as a framework of his thought and both influences and determines his concept of religion. For this reason it seems important to mention some inner inconsistences of his system which were discovered in the process of this investigation. The issues brought to the light by this process of evaluation may contribute to a clearer and more comprehensive understanding of major points of conflict and convergence between cimićs and Christian-theistic conceptions.

Evaluation of Ćimić's concept of religion from the Christian-theistic perspective involves certain difficulties. Ćimié's philosophical presuppositions are entirely atheistic, and he operates mostly at a social and economic plane. Christianity, on the other hand, operates on a theological plane and starts from the presupposition that God exists. Thus, cimic and Christianity have different presuppositions, they use different categories,

\section{${ }^{1}$ Ibid.}


and have, in most cases, different concerns and goals. 1

However, Ćimićs philosophy of religion affirms, implicitly and explicitly, some notions which are related to theological issues. ${ }^{2}$ It is at this level that evaluation of ćimic's concept of religion from the Christian-theistic point of view is being undertaken.

Evaluation of Cimic's concept of Religion from the Marxist-Dogmatic Perspective

Ćimic contends that his philosophy of religion represents the condemnation and rejection of the dogmatic Marxism. ${ }^{3}$ However, it is still possible to trace some

\footnotetext{
${ }^{1}$ For further information, see Charles E. Faupel, "Marxism and Christianity: Their Images of Man," Journal of the American Scientific Affiliation 33 (1980): 139 . 139.

2́cimié, Dogma i Sloboda, 40-41; see also Faupel,

${ }^{3}$ ćimic asserts that it is necessary to make a distinction between the "philosophy of history" and "social philosophy" in contemporary Yugoslav philosophical theory (Ćimic, Dogma i sloboda, 40-41). "Social philosophy," in his view, analyses society as it is in reality by taking into consideration its wholeness, that is, development, goals, and different possibilities. "Philosophy of history," on the other hand, is concerned mainly with partial elements of society (for instance, with its beginning and end). It is dominated by the analytic method ("analytic method" designates the form of the analysis of society which separates or breaks up the whole of society into its constituent elements and which does not take into consideration the interrelation of these elements within the whole of society) which rules over the synthetic ("synthetic method" is used here to designate a form of the analysis of society which attempts to have the truth determined by observation of all empirical facts within the society as well as their interrelationship), and by closed-ness which rules over openness. It is in this thought context that cimic locates dogmatic Marxism. For him, dogmatic Marxism is a "philosophy of history" not a "social philosophy." In
} 
elements in his philosophy which are inconsistent with a humanist Marxism and which clearly characterize the dogmatic Marxist position. Thus, before we evaluate ćimic's major humanist contributions to the understanding of the religious phenomenon, we first critically approach the dogmatic Marxist aspects of his philosophy.

Similarities

There are at least three elements in cimic's philosophy of religion which, in my view, demonstrate that he has preserved some features of the dogmatic Marxist criticism of religion: (1) the prime importance of socioeconomic circumstances in relation to the ideational

Ćimic's view, Marx in his analysis takes into consideration the "whole of society" (a synthetic approach) and not only its partial elements (an analytical approach). Marx does not remain on the theoretical level but points out those things in society which generate human alienation. Consequently, every approach which does not take the entirety of facts of experience into consideration in its interpretation of Marx's work is, in ćimić's view, incorrect (see idem, Ateizam kao Povijesni Humanizam, 7-8). In addition, cimic states that the dogmatic Marxism began with Lenin whose interpretation of Marx's thought represents just one possible, narrow philosophical perspective. Stalinism is seen as a theoretical consequence of Leninism and thus embodies a much more reduced (partial, incomplete, or fragmentary) representation of Marx's work. Stalinism, which is the paradigm of dogmatic Marxism, rises the economic base of society to the level of a general theoretical norm. Thus, in the countries where communism is an official doctrine, individual freedom is sacrificed in the name of the economic development of society as a whole. Moreover, dogmatic Marxism approaches the phenomena of ethics, aesthetics, and religion from the perspective of the theory of reflection. This theory is totally opposed to Marx's concept of man as an active and creative being, that is, a being of praxis (see above, 106-107; ćimic's letter, 1990; Dogma i sloboda). 
superstructure, (2) the possibility of the "light of consciousness" in religious people, and (3) his view of atheism as a "demystified consciousness."1

The Prime Importance of the Socio-economic Conditions

ćimic unquestionably stresses, especially in Drama Ateizacije and Ateizam kao Povijesni Humanizam, that religion is a structurally complex, multi-faceted phenomenon and that, besides being socio-economically mediated and determined, it is also onto-anthropo-psychologically founded and conditioned. ${ }^{2}$ Religion is a psychical, moral, and social fact with manifold and undetachable origins and dimensions. ${ }^{3}$ However, it appears that cimic often emphasizes the dominating character of the socio-economic factors ${ }^{4}$ in relation to religion at the expense of ontoanthropo-psychological factors. ${ }^{5}$ This clearly points to some remnants of the dogmatic Marxism according to which

\footnotetext{
${ }^{1}$ While it is likely to discover other similarities between Cimic's concept of religion and that of dogmatic Marxism, I believe it is possible to group all of them under these three general headings.

${ }^{2}$ See Ćimic, Drama Ateizacije, 201-203; Ateizam kao Povijesni Humanizam, 54-57, 66-77.

${ }^{3}$ See above, 163-186.

${ }^{4}$ Ćimic, Ateizam kao Povijesni Humanizam, 27,34,

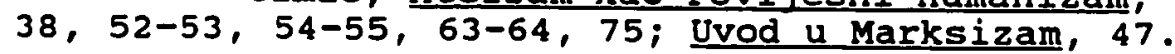

${ }^{5}$ see skledar and Kukor, 7 .
} 
religion is determined by the material substructure of a given society. 1

For instance, ćimić argues that not all sources of religion are socio-economic. However, in his view, the socio-economic sources are essential in the sense that they exercise a dominating influence on all the other sources of religion. ${ }^{2}$ Thus, in order to eliminate the crippled forms of cognition (religion may be one of them) and to create the true, clear, and demystified form of consciousness, it is absolutely necessary, in ćimic's view, to keep discovering the most favorable socio-economic conditions. ${ }^{3}$

Again, when ćimić discusses the concept of "religion per se," he states that while some forms of religion are socio-economically $y^{4}$ determined, there are others which are relatively autonomous. 5 "Religion per se" is not socioeconomicaily determined since it deals with the so-called "last questions" and expresses man's aspirations to transcend his natural condition. Socio-economic conditions

\footnotetext{
${ }^{1}$ see also Kukoc, review of Drama Ateizacije, by Esad Ćimić, 605-607; Skledar, review of Drama Ateizacije, by Esad Ćimié, 163-165.

${ }^{2}$ See above, 116; Ćimić, Ateizam kao Povijesni Humanizam, 63; Uvod u Marksizam, 36, 45, 47, 111-112.

${ }^{3}$ Idem, Socijalisticko Društvo i Reliqija, 43. ${ }^{4}$ Idem, Ateizam kao Povijesni Humanizam, 34, 38, 63 . ${ }^{5}$ Ibid. , 68 ; see above, 199-202.
} 
249

determine only the form of religion, not its essence. ${ }^{1}$

However, Ćimić also maintains that even the "last questions" and man's desire to transcend himself, which represent the principal sources for the existence of religion per se, are mediated essentially by socio-economical means. ${ }^{2}$ This seems to put in question cimic's concept of reality according to which there is no rigid dichotomy between base and superstructure and his contention that the material and the ideational are in a dialectical and not deterministic relationship. ${ }^{3}$ Furthermore, ćimic does not appear to have clarified the sense in which religion per se remains a relatively autonomous phenomenon in relation to economic substructure if its sources are essentially socioeconomically mediated. Then, the difference between such concepts as "essential mediation," that is, dominating influence of socio-economic factors in relation to religion, and determiristic relation between the material substructure and ideational superstructure is not clearly defined. Although ćimić states that he rejects the concept of "causal-determinism," it seems clear that he emphasizes oneway direction of influence, that is, the influence of the socio-economic factors at the expense of the ontoanthropological factors.

\footnotetext{
1'́imic, Ateizam kao Povijesni Humanizam, 68.

2Ibid., 63, 67; idem, Uvod u Marksizam, 47.

${ }^{3}$ See above, 115-116; Ćimić, Uvod u Marksizam, 50.
} 
In addition, ćimic contends that religion as anthropo-psychological structure is given "from herself and in her framework," and thus should be included in the form of religion which cannot be decisively determined by the socio-economic context. ${ }^{1}$ Nevertheless, he also asserts that although religion as an anthropo-psychological structure has relative autonomy, the total influence of the socio-economic environment can be resisted only partially by the individual religious consciousness. 2

Therefore, the impression remains that cimic favors the influence of socio-economic elements on religion to the expense of others factors. ${ }^{3}$ Although this does not mean that Cimic argues for the totally deterministic significance of socio-economic factors in relation to ideational as dogmatic Marxists do, he has apparently preserved some aspects of the dogmatic Marxist view in regard to socioeconomic determinism of religion. ${ }^{4}$

${ }^{1}$ see above, 208-210; Ćimic, "Marx's Critique of Religion and/or Atheism," 523; Ateizam kao Povijesni Humanizam, 75 .

Religije, " 39.

2Idem, "Mogućnosti Marksistiðkog Pristupa Fenomenu

${ }^{3}$ See skledar and Kukoc, 7.

${ }^{4}$ See Kukoc, review of Drama Ateizacije by Esad ćimić, 605-607; Skledar, review of Drama Ateizacije by Esad Ćimié, 163-165. 
The Possibility of the "Light

of Consciousness" in

Religious People

Dogmatic Marxists' enlightenment-rationalistic

concept of religion asserts that religion is the consequence of ignorance and is to be forced out of human consciousness by the introduction of atheistic-rationalistic and scientific facts. Atheistic propaganda, in their view, should demonstrate the irrational and unscientific nature of religious superstitions. ${ }^{1}$

cimic, on the other hand, apparently rejects any kind of atheistic-scientific rationalism in relation to religion by contending that religion is not a conscious illusion but an unconscious self-defence expressing the real situation of man in the world. In his view, the abolishment of religion cannot happen on a cognitive level but should rather be the task of changing the real conditions of the world. 2 In addition, ćimić suggests that science and religion are different forms of spiritual activities and thus scientific knowledge will never be able to wipe out religious belief. ${ }^{3}$

However, contrary to these statements, Cimic also seems to advocate in connection with his view of religion as

${ }^{1}$ See above, 141-143; Ćimić, Socijalisticko Društvo i Religija, 13-14.

2 Ibid.

${ }^{3}$ see above, 131-133. 
the socio-historical fact that the critique of religion by the "light of the consciousness" in religious people is possible. ${ }^{1}$ Thus, he suggests, for instance, that knowledge about the nature of the religious phenomenon may weaken religious orientation up to a certain degree. ${ }^{2}$ In addition, he asserts that the increasing of man's power and knowledge about nature and its forces (i.e., scientific knowledge) offers the possibility of the enlightenment of religious consciousness. ${ }^{3}$ Accordingly, "limited atheization" of the religious mind is possible in cimic's view. 4

Therefore, it seems that cimic has preserved some elements of the dogmatic Marxist concept of religion since, for him, the introduction of certain forms of knowledge into the mind of a religious man will enlighten his consciousness. 5 Moreover, this expectation seems to contradict ćimic's assertion that religion is an unconscious illusion of human phantasy.

1'́imic, Ateizam kao Povijesni Humanizam, 70; see Skledar and Kukoc, 7; Kukox, review of Drama Ateizacije by Esad Ćimić, 605-607; Skledar, review of Drama Ateizacije by Esad Ćimié, 163-165.

2ćimic, Socijalistiðko Društvo i Reliqija, 16.

${ }^{3}$ Idem, Ateizam kao Povijesni Humanizam, 70-71.

${ }^{4}$ See above, 206.

${ }^{5}$ see skledar and Kukor, 7 . 


\section{Atheism as a "Demystified} Consciousness"

The traces of enlightenment-rationalistic concept of religion, which characterizes the dogmatic Marxist philosophy, is also evident in cimie's description and analysis of atheism. ${ }^{1}$ First, cimic rejects the forms of atheism as "negative theologies" and argues in favor of "socially transforming atheism" which, in his terms, is a "theoretical agnosticism" and a "practical humanism."2 Hence, it is not "anti-religious" but "a-theistic." 3 However, cimic also observes in relation to the concept of "socially transforming atheism" that it "is a rational standpoint which bases its position on scientifically-proven facts about the universe, history, society, and man."4 In addition, he argues that religion is the "expression of perverted relations in alienated society" while "atheism is the expression of the demystified consciousness" which influences the shaping of human relations. 5

Second, "state atheism," which in socialist countries plays the role of "state religion," is, for cimic,

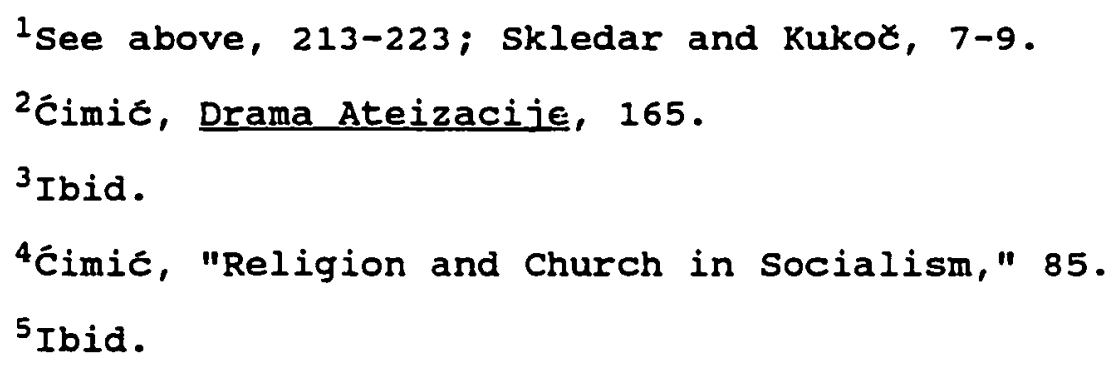


unacceptable. ${ }^{1}$ Therefore, he suggests that atheism as a worldview should not be attached to and used by any political power. ${ }^{2}$

However, he also maintains that atheism is "the constitutive element of the socialist program for the development of total personality."3 How is this then to be detached from the political power? This inconsistency may be only partially justified by cimic analysis of atheism as a complex phenomenon. ${ }^{4}$ cimic rejects the idea of atheism as a "disappointed religious consciousness," 5 arguing instead for "socially transforming atheism."6 This concept constitutes the core of his philosophy and, at the same time, his proposal for liberation from every historical, existential, and social alienation. ${ }^{7}$ Accordingly, Ćimić would probably argue that atheism which can be described as "the constitutive element of the socialist program for the

\footnotetext{
1'Cimic writes: "The social wave of atheization which is founded on and framed on the scientific picture of the world should be rejected." Thus, for him, atheization imposed by the society merely means the exchange of one religion with another (idem, Drama Ateizacije, 211-212).

${ }^{2}$ Ibid.

3'Ibid., 65.

4Ibid., 62-69; see also Kukoc, review of Drama Ateizacije by Esad ćimić, 605-607; Skledar, review of Drama Ateizacije by Esad Ćimić, 163-165.

5 Ćimić, Drama Ateizacije, 188.

${ }^{6}$ Ibid., 62-63, 67 .

${ }^{7}$ See Skledar and Kukoc, 8-9.
} 
development of total personality" and "the most sensitive indicator of spiritual freedom of man" refers to his own concept of "socially transforming atheism." However, the inconsistency remains because he defines even the "socially transforming atheism" as "a rational standpoint," thus contradicting his assertion that it is only "practical humanism" and "theoretical agnosticism."I

Third, Ćimic defines atheism as "the shadow of religion which followed religion throughout its history and keeps troubling it." 2 Atheism is an antipode and at the same time a correlate of religion. ${ }^{3}$ Religion, on the other hand, is the hypothesis of atheism, and atheism would necessarily destroy itself to the extent to which it would destroy religion. 4

These statements do not seem to be consistent with his "eschatological" view of atheism as "the most sensitive indicator of spiritual freedom of man" which is to

IIbid.

${ }^{2}$ Ćimić, Drama Ateizacije, 66; "Religion and Church in Socialism," 85; Religion and Self-Management, 125.

${ }^{3}$ Idem, Drama Ateizacije, 66.

${ }^{4}$ Ibid.

5I use the term "eschatological" here to designate cimic's belief in the possibility of liberation of man in the future communist society in which atheism will be the indicator of spiritual freedom of man (ibid., 69; Uvod u Marksizam, 200. See also Skledar and Kukoc, 8). 
be realized in the future communist society. 1

If atheism in the process of destroying religion destroys itself, how can it exist in the eschaton?

Fourth, cimic says that the possibility of complete historical realization of human dealienation, that is, "demystified consciousness" (atheism), is presumed as certain in some of Cimic's statements. ${ }^{2}$

This appears to be in contradiction with his arguments that there are problems that man faces "which cannot be taken away totally by any social change." 3 since certain limitations of human onto-anthropological structure cannot be changed, "man will always need to resolve some problems in the transformed form of religion."4

Therefore, it seems clear that cimic's concept of religion includes some elements of rationalistic Marxist dogmatic theory which are inconsistent with his humanist ideas. However, these remnants of the dogmatic Marxism in

\footnotetext{
1'Ćimić, Drama Ateizacije, 65.

2Idem, "Religion and Church in Socialism," 85.

${ }^{3}$ Ćimić, Drama Ateizacije, 188.

${ }^{4}$ The future communist society, in cimićs view,
} should not be imagined as a society combining of religious people and atheists. Rather such a society "will find its support and reason for human existence in philosophic religion or religious philosophy" (the terms "philosophic religion" and "religious philosophy" denote, in the context of cimic's thought, the so-called "transformed form of religion" which may possibly exist in a society freed from the socio-economic contradiction) (ibid; see also skledar and kukoc, 9). 
Ćimie's philosophy of religion, although significant, seem to be secondary in comparison with his many contributions to the humanist-Marxist reconceptualized concept of religion.

\section{Differences}

In my view, cimie's main contributions to the humanist reconceptualization of the dogmatic Marxist criticism of religion are: (1) the introduction of a new way of thinking about religion from a Marxist perspective, (2) the formulation of a new method of interpreting Marx, (3) the rejection of the dogmatic Marxist concepts of religion which existed in communist countries, (4) the assertion that religion is not a simple but a multi-faceted phenomenon, (5) the contention that religion is not opposed to science, and (6) the acceptance of the possibility that some forms of the religious phenomenon will never disappear.

\section{New Way of Thinking}

About Religion

Yugoslav philosophy and sociology of religion, which developed between 1945 to 1966, was characterized by various attempts to formulate and establish the Marxist concept of religion. ${ }^{1}$ The majority of Yugoslav Marxist philosophers, with very little independent thinking, based their ideological-philosophical critique of religion on the soviet dogmatic view of historical and dialectical materialism.

loršolić, "Marksistiðka Sociologija Religije u Jugoslaviji," 54 . 
During that period, we usually find sterile, prosaic statements about the religious phenomenon instead of an inventive empirical-sociological analysis of religion. Such prosaic views were often based on isolated ideas of Marx, Engels, and Lenin which were usually taken out of their historical, social, and economic context. ${ }^{1}$

Cimic, on the other hand, abandoned this approach as a fruitless, dogmatic exercise and introduced a new, creative, cautious, more objective approach based not only on the totality of Marx's work but also on his personal empirical-sociological research. ${ }^{2}$ In Ćimićs view, Marx's statements about religion primarily referred to its function, and only secondarily were they concerned with religious infrastructure. ${ }^{3}$

Ćimić's Drama Ateizacije is characterized by an intense desire for objectivity. It is one of the most detailed works ever written on religion by a Marxistatheist. 4 with his philosophical analysis, psychological remarks, humanist ideas, and critical questions, ćimić

IIbid., 55 .

${ }^{2}$ See above, 191; Ruptić, "Atheismus und Religion," 150-153; Muhić, review of Socijalistiðko Društvo i Religija, 812; Kecmanović, review of Drama Ateizacije, 211-213; Kukoc, review of Drama Ateizacije, 607.

${ }^{3}$ oršolic, 57 .

${ }^{4}$ Srdjan Vrcan, review of Drama Ateizacije, in Gledišta 26 (1985): 128-129; Rudi Supek, review of Drama Ateizacije, in Gledišta 26 (1985): 154-155. 
appears to have successfully avoided the sterile and routine thinking on religion adopted by dogmatic Marxist philosophers. 1

New Method of Interpreting Marx

Dogmatic Marxists maintain that Marxism is a total, all-inclusive worldview which answers all fundamental human questions. Hence, they see no need for other worldviews. 2 They argue that Marx developed an infallible philosophy not only of religion but of nearly all other subjects. ${ }^{3}$ Marxism as materialism is considered by dogmatic Marxists to be totally atheistic and, hence, hostile to all religion. 4

cimic, on the other hand, argues that Marx's critical philosophy is not to be considered as final and perfect. 5 Marx is to be seen as giving hints which interpret various phenomena and it is not legitimate to transform them into final conclusions. 6 Marx's starting point of radical historical humanism should serve as the

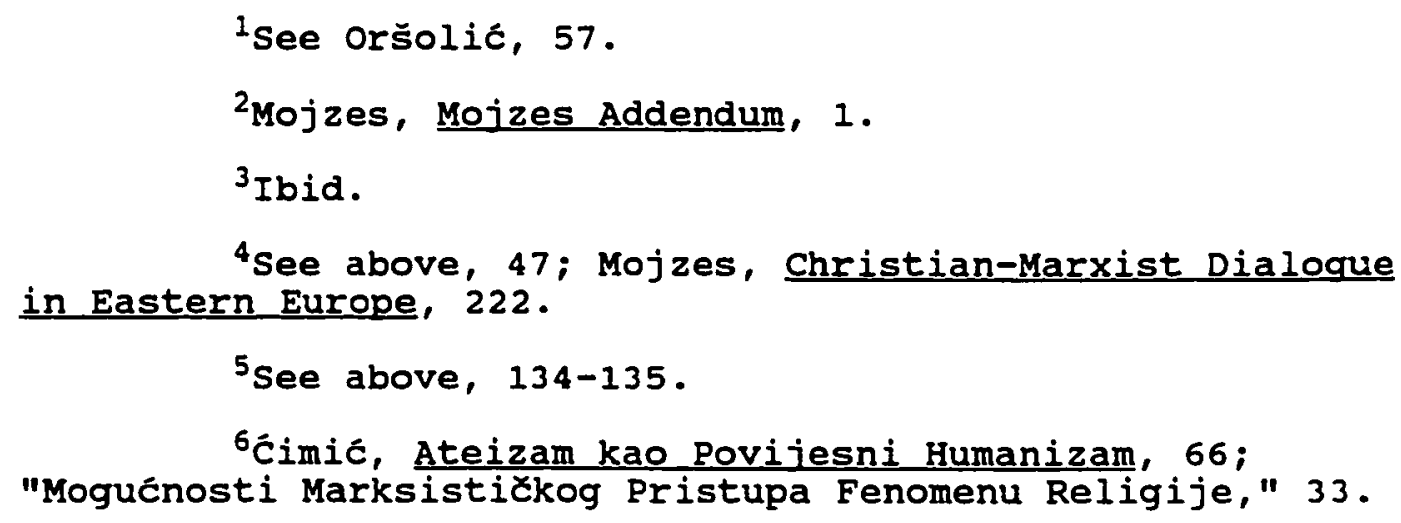


methodological framework for the examination of his thought. ${ }^{1}$ In addition, Marx does not approach religion in an a priori way as either positive or negative, but analyzes its direct dependence on the socio-historical conditions. ${ }^{2}$ Religion is not predetermined a priori to be alienation because all forms of consciousness are only potential forms of alienation in the measure in which they support class injustices in capitalist society. ${ }^{3}$ Thus, Marxism is not viewed as hostile to religion. In fact, in cimić's opinion, Marx's philosophy may be legitimately defined as historical humanism rather than atheism. ${ }^{4}$

Rejection of Dogmatic Marxist Concepts of Religion Used in Socialist Countries

Dogmatic Marxist philosophers argue in favor of the use of enlightenment-rationalistic concept toward religion. Accordingly, religion is seen as the consequence of an ignorance which can be forced out of human consciousness by the introduction of rational, scientific facts into the human mind. 5 cimic, on the other hand, in spite of some

${ }^{1}$ Ibid.

Ibid., 31.

${ }^{3}$ Idem, Ateizam kao Povijesni Humanizam, 64.

${ }^{4}$ See idem, "Marx's Critique of Religion and/or Atheism," 521; Dogma i Sloboda, 132.

${ }^{5}$ See above, 141-144; Ćimić, Socijalističko Društvo iReligija, 13. 
remnants of the enlightenment-rationalistic concept in his view of religion, rejects it. ${ }^{1}$ He maintains that proponents of the enlightenment-rationalistic concept take only the cognitive element as the essential source of religion, while overlooking the dialectical interaction between the different factors within society. ${ }^{2}$ Religion is not a conscious, but an unconscious self-defense which expresses the real situation of man in the world. ${ }^{3}$

Dogmatic Marxists also embrace the spontaneouseconomic concept of religion according to which religion is seen as the result of the economic substructure of society. As such, it will disappear in proportion to the development of the economic conditions of society. 4 cimic argues against the idea of the totally deterministic significance of economic factors in the total social development. For him, this approach negates the importance of human conscious action. 5 He suggests, instead, that human consciousness is influenced in many ways by the socio-economic situation, but socio-economic situation is also in many ways influenced by human consciousness. He also states that man's future is an

${ }^{1}$ For further information, see above, 250-256.

2́cimić, Socijalističko Društvo i Religija, 13.

3Idem, "Religion and church in Socialism," 88-89.

${ }^{4}$ Ibid., 89-90; see above, 145-147.

5́cimic, Socijalisticko Društvo i Religija, 17. 
act of man because it is human action which leads to a different social situation. ${ }^{1}$

Dogmatic Marxists have advocated in all communist countries the use of the administrative procedures against religious people. ${ }^{2}$ The philosophy behind this practice is that religion can be suppressed by pressure on the minds of religious people. ${ }^{3}$ Ćimic denounces the use of such procedures against religious people. He maintains that methods involving force are not only unable to free man from religion but, in fact, result in a new source of religion. 4 In cimie's view, anti-religious pressure deprives man of his own consciousness, his feelings of personal responsibility, and thus, only prolongs the life of religion. 5

\footnotetext{
1'Cimié did not successfully resolve the problem of the relationship between human free will and historical determinism. The same problem may be seen in the philosophical systems of most humanist-Marxist philosophers. Thus, we find in cimić's works such statements as "man's future is an act of man," yet there are also assertions that "man is free when he enters into the deterministic relationship and attempts within this relationship to develop his own structure which corresponds to his personal needs" (ibid). How man can be free and still be determined by an objective reality outside of himself is not quite clear (see idem, Uvod u Marksizam, 58).

${ }^{2}$ see above, 148-150.

3́cimié, Socijalisticko Društvo i Religija, 17.

${ }^{4}$ Idem, "Politicko i Idejno Suocavanje s Religijskim Fenomenom," 191-195.
}

${ }^{5}$ Ibid. 
Religion Is Not a simple, but a Multi-dimensional and Relatively Autonomous Phenomenon

According to the dogmatic Marxist view of the relationship between material substructure and ideational superstructure, the creation of thinking, consciousness, and ideas is directly connected with the material activity of human beings. ${ }^{1}$ Consequently, dogmatic Marxists embrace a simplistic approach to the religious phenomenon. In other words, religion is nothing more than the expression of the real distress caused by corrupted economic circumstances in the class society. ${ }^{2}$

Ċimić rejects this dogmatic Marxist approach toward religion as simplistic, arguing instead that religion is a complex, multi-faceted phenomenon. ${ }^{3}$ He is not willing to accept the assertion that the economic base of society is the only or the totally deterministic factor in the creation of religious consciousness. 4 Although, as we have seen above, 5 Ćimić seems to favor the influence of socioeconomic factors at the expense of others, he must be credited with creating a concept of religion which must be

\footnotetext{
${ }^{1}$ See McGovern, 255-262; see above, 37-38.

${ }^{2}$ McLellan, Marxism and Religion, 36-39.

3ćimić, Drama Ateizacije, 6; see above, 247-249.

4'Cimic, "Marx's Critique of Religion and/or Atheism," 522 .

${ }^{5}$ see above, 247-249.
} 
approached as an multi-dimensional and relatively autonomous phenomenon. 1

Hence, for instance, when cimic discusses the

concept of religion "per se," he approaches it as a

relatively autonomous phenomenon because its main sources

are the so called "last questions." 2 The concept of the

1'́imić, Drama Ateizacije, 200-203.

${ }^{2}$ Idem, Ateizam kao Povijesni Humanizam, 66. Srdjan Vrcan argues that ćimic's concept of "last questions" is ambivalent. He states that the concepts of "last, " $f$ inal," and "ultimate" may have several different meanings with very important theoretical implications for the understanding of religion. "Last," "final," and "ultimate" may be used to mean "ultimate reality" which designates the reality that is ontologically different and superior in relation to the natural, historical, and human reality. Then, "last," "final," and "ultimate" may be used to refer to "ultimate" or specific problems of human existence that are independent of the historical situation and which exist regardless of whether people recognize their existence or not. Again, "last," "final," and "ultimate" may mean "ultimate" or universal, necessary solutions of "ultimate problems." Finally, the category of "last," "final," and "ultimate" may designate something that concrete people in specific historical and social circumstances experience as an extremely important object of their concern. According to Vrcan, Ćimićs use of "last," "final," and "ultimate" vary from something that is absolutely supra-historical, suprasocial, and supra-cultural to something that is an important object of people's concern. Thus, Vrcan criticizes ćimic for his imprecise and ambivalent use of the term "last questions." In Vrcan's view, a clearer position would have contributed to a much clearer concept of religion in cimic's philosophy. The relativization or absolutization of the concept of "last," "final," and "ultimate" have, according to Vrcan, very different theoretical consequences for the understanding of religion.

Vrcan also points out that there is an inconsistency in the definition of the concept of "last questions" in Cimic's Drama Ateizacije. In one part of the book, according to vrcan, ćimic takes the position that there are supra-historical, supra-social, and supra-cultural questions concerning human existence which demand two possible types of answers: religious and philosophical. However, in 
"last questions" is closely related to the notion of man's need for "self-transcendence."1 Religion (as well as art and philosophy) is one form of human self-transcendence ${ }^{2}$

another context of the book, cimic states that the only answer to "last questions" may be found in religion (see Vrcan, 132-133).

I tend to disagree with Vrcan because it seems clear that, in cimic's view, the terms "last," "final," and "ultimate" represent realities that transcend the concrete socio-historical situation, but which are always the result of the historical experience of humanity. Religious people may think that "ultimate" is ontologically superior in relation to natural, but it is nothing but illusion.

1The "last questions" are the source for man's desire to transcend himself (Ćimic, Ateizam kao Povijesni Humanizam, 66-67).

${ }^{2}$ Vrcan argues that there is ambivalence in the use of the concept of "transcendence" in Cimic's thought. In Vrcan's view, the concept of "transcendence" may have several different meanings. First, it designates something that stands on the other side of the purely biological character of human organism. Second, it designates all phenomena that belong to the society and surpass the subjective, individual consciousness. Third, it designates all that stands on the other side of the this-worldly life. According to Vrcan, cinic uses the term

"transcendence" in several ways without clarifying it. Thus, first, in Vrcan's view, Cimic uses the term to designate the fact that contemporary man, whether theist or atheist, searches for God. Their relation to that transcendent reality is essentially the same; only the form of the transcendence is different. Second, according to Vrcan, cimic uses the term to explain an aspect of man's nature--the desire to transcend everything existing. Thus, Vrcan concludes, if cimic uses the term "transcendent" to designate a reality existing in the area of the this-worldly, then he uses it in accordance with Marx's thought. But, if by "transcendent" Cimic means the reality in the other-worldiy (Vrcan seems to imply that cimic does use the term in that sense), then his meaning is in radical opposition with Marx. I disagree with Vrcan's critique because it seems obvious that cimic uses the term "transcendent" to indicate this-worldly realities that are the result of the historical experience of humanity. ćimic always remains on the horizontal level and denies any real existence to the other- 
which may inspire people to fight against the injustices of this world by replacing it with something more enjoyable. ${ }^{1}$ Accordingly, with the concept of religion as one form of man's transcendence, ćimić introduces a theory completely opposite to dogmatic Marxism, that religion, in addition to being alienation, also may be positive in some of its forms. It implies that religion is complex rather then a simple phenomenon.

Furthermore, ćimić's concept of religion as a anthropo-psychological structure ${ }^{2}$ suggests that the economic base of society does not influence the human mind directly but through the medium of personal anthropopsychological formation. This later aspect of human nature, which is unique for each individual, is, to a certain measure, able to resist the influence of the economic environment. ${ }^{3}$ The fact that the individual psychological structure possesses relative autonomy means, for cimić, that

\footnotetext{
worldly realities. For instance, the concept of God cimic views as unestablished in reality and as the socially conditioned projection of the human being which takes from the believer the best of human qualities (see Vrcan, 33-134; ćimić, Socijalisticko Društvo i Religija, 26-27).

${ }^{1}$ Idem, Drama Ateizacije, 200-201.

${ }^{2}$ see above, 208-210.

${ }^{3}$ See Ćimić, "Mogućnosti Marksistið̌og Pristupa Fenomenu Religije," 39.
} 
the basis for the origination of religiosity is derived "from herself, in her framework, and by herself." I

Therefore, for ćimic, the phenomenon of religion, contrary to dogmatic Marxism, is not the simple epiphenomenon of matter. Rather, it is a result of dialectical interrelationships of different factors within the totality of reality.

Religion Is Not Opposed to Science

Dogmatic Marxists maintain that religion is an unscientific and superstitious view of the world. They assume that science has triumphed over religious belief and that philosophical materialism, viewed dialectically, is the necessary basis for all science. ${ }^{2}$ science can explain, for instance, the origins of human kind and human thought without any reference to God. In summary, science has superseded religious explanations of the universe and human origins, replacing them with the dialectical materialist view of reality. 3 Therefore, where reason and science appear, gods and religion disappear. 4

Ćimić rejects the dogmatic Marxist understanding of

IIdem, "Marx's Critique of Religion and/or
Atheism," 523.

${ }^{2}$ See MCGovern, 255.

${ }^{3}$ Ibid. , 266-257.

4'́imié, Socijalisticko Društvo i Religija, 14. 
the relation between science and religion. For him, science and religion are disparate forms of spiritual activity which do not meet in the essential because the objects of their interest are totally different realities. ${ }^{1}$ The object of scientific investigation is the area of the empirical, that is, the historical, social, and natural. On the other hand, the object of religious interest is supra-historical, otherworldly, and supra-empirical. ${ }^{2}$ science cannot deny religion. Yet, it cannot verify religion either. ${ }^{3}$

vrcan points out two weaknesses in cimić's view of the relationship between science and religion. First, he argues that cimic's discussion concerning the relation of science and religion deals with the relation of "religion per se" and science while excluding "traditional religion" which exists in the concrete historical situation. ${ }^{4}$ This implies, according to Vrcan, that cimić considers "traditional religion" to be a kind of degraded aberration, a lower kind of religion which only has an "accidental" meaning in relation to "essential religion" (i.e., "religion per se"). This means, in Vrcan's opinion, that historical experiences of the relation of science and religion become 133.

${ }^{1}$ See idem, Dogma i Sloboda, 127; see above, 131-

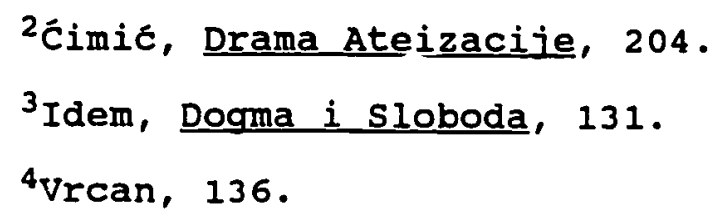


theoretically irrelevant or else appear merely as an indicator of historical "accidents," not as evidence of important moments in the relationship between science and religion. 1

I tend to disagree with Vrcan's critique because he seems to forget that ćimic relates religion in its "ideal" form to science in its "ideal" form. 2 History also demonstrates that there have been misuses and abuses in the field of science. ${ }^{3}$ For that reason, it would appear to be inconsistent to relate "traditional religion," which in ćimić's philosophy denotes aberration of the "ideal religion," to the "ideal concept of science."

Second, Vrcan argues that cimic's concept of the relation of science and religion is almost entirely predetermined by his critical reaction to the enlightenmentrationalistic notion of the necessary conflict between science and religion. This predetermination, in Vrcan's view, has narrowed cimic's theory. ${ }^{4}$ Thus, Vrcan reminds us

\section{${ }^{1}$ Ibid.}

${ }^{2}$ It also must be pointed out that there is no agreement on what is "ideal" science (see John Habgood, "Science and Religion," The Westminster Dictionary of Theology [1983], 526-528). In Ćimic's view, "ideal science" is human activity which deals with the realm of empirical and participates in the creation of better social conditions (Ćimić, Drama Ateizacije, 210).

${ }^{3}$ For instance, the use of people for the scientific experiments during the Second World War.

4vrcan, 136 . 
that outside of enlightenment-rationalistic and dogmatic Marxist circles, there are authors who emphasize an unavoidable tension between science and religion while not insisting on the necessity of conflict between the two. ćimic, according to Vrcan, does not take into account these possibilities and, consequently has formulated a narrow theory. In short, Vrcan contends that the solution offered by ćimic is interesting, but not less problematic than any other. ${ }^{1}$

In my view, the fact that cimic has decided to formulate his theory of the relation of science and religion as a reaction to the dogmatic Marxist position does not mean that he was predetermined to come to such a conclusion or that he was unaware of other theories dealing with the relation of science and religion. In addition, we must point out that there are, among theologians and philosophers, a wide variety of opinions concerning the relation of science and religion. I agree with cimic that there is no opposition between science and religion. However, contrary to Ćimie as well as dogmatic Marxism, I would argue that science and religion share a concern for the same reality, but they each approach it from different perspectives and with different questions in mind. 2

\footnotetext{
IIbid., 136-137.

${ }^{2}$ For further information, see Habgood, 526-528.
} 
Religiosity Will Probably Not Disappear in Any Future

Form of Society

According to the dogmatic Marxist theory, religion will vanish and the idea of God will be abolished in future communist society. 1 Religious consolation will be unnecessary for two reasons: first, man will be in a position to control the process of production; and second, the development of materialistic science will render completely redundant the idea of God. ${ }^{2}$

cimic, on the other hand, argues that when the socio-economic sources which produced religion are eliminated and the self-management society established, religion will probably not disappear but may only change its form. ${ }^{3}$ Since man will never lose the desire and need for

${ }^{1}$ Lee, 586 ; see above, 46 .

${ }^{2}$ McLellan, Marxism and Religion, 54-56.

${ }^{3}$ Ćimić, "Mogućnosti Marksističkog Pristupa Fenomenu Religije," 39-40. It seems to me that cimić did not go as far as he could have in his definitions of the relationship between the socio-economic base and the nature of religion or religion's future. There is a tension in his thought between the desire to show that religiosity is a universal psychological fact which will always exist in some form and his belief that religiosity, however, is mediated by socioeconomic conditions. Some other Yugoslav humanist-Marxists (for instance, Kerševan and stankovic) have gone further than cimic and stated that religion is not an alienation related to the oppressive economic situation but, rather, a specific social practice through which human beings receive what they do not have because of the natural human limitations (see Kerševan, "Neka Sporna Pitanja Marksistið̌ke Teorije Religije," 980-990; Stankovic, "Čovek i Religija," 650). When supek discusses ćimić's concept of religiosity, he argues that human self-transcendence may or may not be mediated by the socio-economic conditions. For supek, man 
self-transcendence, some form of religion will always exist. 1

\section{Evaluation of Inner Inconsistencies in the Theoretical Base of ćimie's Philosophy}

We now turn to the second objective of this chapter, that is, evaluation of some inner inconsistences of cimic's philosophical system. Ćimie's concept of religion forms part of his philosophical system and is determined by it. Consequently, discussion of the inconsistences of his system may contribute to a better and more complete understanding of major points of conflict and convergence between ćimic's and Christian-theistic conceptions.

First, Ćimié claims to be a materialist. He contends that matter is the basis for all other phenomena. ${ }^{2}$

is confronted with the alternative of choosing between accepting and rejecting religion. This alternative is part of human nature and one of the basic elements of the individual freedom of every person. Man is seen as a contradictory being who is in constant interaction and dialogue with himself (i.e., with his ego). Thus, according to supek, the decision to accept or reject religion is the result of the interaction of man with himself rather than resulting from the establishment of a self-management society or the development of favorable social-economic conditions at some time in the future (see cimic, "Marx's Critique of Religion and/or Atheism," 524 ; Ateizam kao Povijesni Humanizam, 67; Supek, review of prama Ateizacije, 154-156). above, 210 .

1'́imić, Ateizam kao Povijesni Humanizam, 75; see

${ }^{2}$ Ćimić, Uvod u Marksizam, 45, 69-71, 111-112. ćimić, however, rejects dogmatic Marxist assertion that material and ideational are in the causal relationship (see above, 115-118). 
However, Ćimić also asserts that some elements in the structure of human nature may be considered as essential and universal because they transcend the concrete sociohistorical situation.1 Thus, such terms as "human essence" or "genetic being" designate in ćimie's philosophy an ideal, i.e., an a priori category subjectively realized when socioeconomic conditions become rational. Therefore, although cimic contends that this "essentiality" is the result of the historical experience of humanity, ${ }^{2}$ it seems that he vacillates between materialism and idealism whose roots are Hegelian. ${ }^{3}$

Second, ćimic asserts that God is not a real entity but a socio-psychologically conditioned human projection. ${ }^{4}$ Thus, the idea of God is basically produced by human feelings of dependence, wishes and needs, drive for

\footnotetext{
${ }^{1}$ See above, 227 ; Ćimić, Ateizam kao Povijesni Humanizam, 62 .

2Ćimic, Ateizam kao Povijesni Humanizam, 61.

${ }^{3}$ For further information on the problem of inconsistency in humanist Marxist concepts of metaphysics and epistemology, see Gorman, Neo-Marxism, 75-85.

"We use here the term "socio-psychological sources" not as a general term which encompasses all the sources of religion in cimic's philosophy, but only in reference to the anthropo-psychological sources. However, it is necessary to keep in mind that in cimic's philosophy of religion the anthropo-psychological sources are in the dialectical relation with socio-economic and other sources of religion and thus they influence and are influenced by all other sources within the totality of reality (see above, 224, 115117; Ćimić, Socijalisticko Društvo i Religija, 26-27).
} 
happiness, and instinct for self-preservation. ${ }^{1}$ It is true that the whole man is involved in knowing God. Feelings of dependence and the various human aspirations do play an important role in religion. ${ }^{2}$ However, the sociopsychological explanation does not tell us everything about the very complex phenomenon of belief in God. For instance, one may argue that cimic's formulation of the idea of God as nothing but the projection of human wishes and drives expressed in an unconscious process is incorrect, since, in addition to feelings, Christian belief involves reason which provides limited but important knowledge about God based on the existence of universe and human moral experience ("general revelation"). 3 Furthermore, the fact that sociopsychological factors do play an important part in belief in God does not necessarily imply that they are not directed to a real object, a reality. Undeniably, the possibility that there is not a real object corresponding to human wishes, needs, and instincts cannot be excluded. On the other hand, one cannot exclude a priori the possibility of the actual existence of a reality which corresponds to human wishes,

\footnotetext{
'Idem, Uvod u Marksizam, 86-87; Dogma i Sloboda, 122-123; Drama Ateizacije, 44-45.

${ }^{2}$ See Hans Küng, Does God Exist? (Garden City, New York: Doubleday and Company, 1980), 209.

3Jerry H. Gill, "Reason," The Westminster Dictionary of Christian Theology (1983), 486 .
} 
needs, and instincts. 1 It is quite correct to say that nothing exists only because we wish it, but it is not true that something cannot exist just because we wish it. Therefore, "something real can certainly correspond in reality to my psychological experience; a real God can certainly correspond to the wish of God."2

Third, ćimić argues that it is necessary to establish the most favorable socio-economic conditions in order to enable the creation of a true, clear, and demystified consciousness (i.e., consciousness liberated from religious and other illusions). ${ }^{3}$ Contrary to his assertion that human consciousness does not correspond to material substructure because material structure and ideational superstructure are in a dialectical interrelation, ${ }^{4}$ cimic also maintains that socio-economic

\footnotetext{
${ }^{1}$ Küng's evaluation of Feuerbach's critique of religion is valid for ćimic since he (Ćimic) holds the same view on this point. Küng writes: ". . . might not our feeling of dependence and our instinct for self-preservation have a very real ground; might not our striving for happiness have a very real goal? And if, as with all knowledge, so, too, with my knowledge of God, I put-projectinto the object much of myself, does this alone prove that the objects merely my projection, my fantasy, and otherwise nothing? Might not perhaps some real object, some sort of reality, correspond to all our wishing, thinking and imagining. If I speak in a human way about God, does this mean that the God of whom I speak is merely something human?" (Küng, 209).

2Ibid., 210 .

${ }^{3}$ See above, 171-172; Ćimic, Socijalisticko Društvo i Religija, 43 .

${ }^{4}$ Idem, Uvod u Marksizam, 71.
} 
sources of religious ideas are essential in the sense that they exercise the dominating influence on all other sources of religion. ${ }^{1}$ If the socio-economic conditions are essential in the creation of man's consciousness, then ćimic's theory does not offer a convincing explanation for the cause of man's diverse, unique, and totally opposite ideas to the existing socio-economic reality. It seems that reality and thought would essentially have to correspond. ${ }^{2}$ For instance, how does one explain the emergence of utopian ideas? In addition, cimic does not appear to offer any explanation as to why man is capable of reflecting objectively on the world of nature, of which he essentially forms a part. ${ }^{3}$ Cimić acknowledges that each person's anthropo-psychological structure is unique, 4 but he does not explain the real cause of this uniqueness. Accordingly, the fact that some people are religious and others are not is contrary to the concept of the essentiality of socioeconomic conditions for the formation of human consciousness. Therefore, the basic weakness of cimic's critical theory of religion can be seen in its hypothetical

\footnotetext{
${ }^{1}$ Idem, Dogma i Sloboda, 131.

${ }^{2}$ For further information, see samuel Enoch Stumpf, Philosophy: History and Problems (New York: McGraw-Hill Book Company, 1983), 415-416.

${ }^{3}$ Andrew Kirk, "The Meaning of Man in the Debate between Christianity and Marxism," Themelios 1 (1976): 87. Religije," 39 .

${ }^{4}$ Ćimic, "Mogućnosti Marksistickog Pristupa Fenomenu
} 
character and its lack of a precise description of the relation between material and ideational. 1

Fourth, Ćimic assumes the eternal existence of the material world and thereby attempts to deny the existence of God and creation of the world. ${ }^{2}$ However, the thesis which argues for the eternity of the material world cannot be proven by the science. ${ }^{3}$ It is, after all, in itself an a prioristic, arbitrary preconception which seems to result from Ćimić's atheistic attitudes. Moreover, the classical proofs 4 for the existence of God do not rest on the fact of the origin of the world in time. ${ }^{5}$ The beginning of world in time is a fact which cannot be determined either empirically or philosophically. The basis of the classical proofs for God's existence is a deduction from the world's

\footnotetext{
${ }^{1}$ This is contrary to cimic's claim that religion is a complex phenomenon which needs to be thoroughly analyzed (idem, Drama Ateizacije, 12).

${ }^{2}$ Ibid., 183 .

3Wetter, "Dialectical Materialism," 425.

${ }^{4}$ Here I think of the so-called a posteriori arguments for the existence of God: the cosmological, the teleological or design argument, and the moral argument. The a posteriori arguments give evidence for the existence of God from the world, from the observable, empirical universe. God is considered to be necessary to explain certain features of the cosmos. I do not include here the ontological argument which uses an a priori approach according to which God as a being is so perfect that his nonexistence is inconceivable (A. J. Hoover, "God, Arguments for the Existence of," Evangelical Dictionary of Theology $(1984), 447)$.

${ }^{5}$ See Wetter, "Dialectical Materialism," 425.
} 
contingence, that is, the fact that the world does not exist by an inner necessity, but is itself indifferent with respect to existence. Hence, the fact that the world does exist implies that it owes its existence to another. 1 Fifth, Cimic embraces the concept of the dialectical movement of history. ${ }^{2}$ For him, as well as for other Marxist philosophers, the introduction of dialectics into materialism solves the problem of movement, which is understood as an upward development. ${ }^{3}$ Thus, for ćimic, the origin of the dialectical movement is to be found in the "contradiction" or "struggle of opposites."4 However, there is a difference between the "contradiction" and the "struggle of opposites." "Contradiction is a simultaneous assertion and denial of one and the same proposition occurring within or between contentions, assumptions, suppositions, and other forms of asserting discourse." 5 In practical reality, "contradiction" (i.e., assertion "A" and its negation "Non-A") is not possible. Rather, it exists only as a mental concept occurring with logical questions

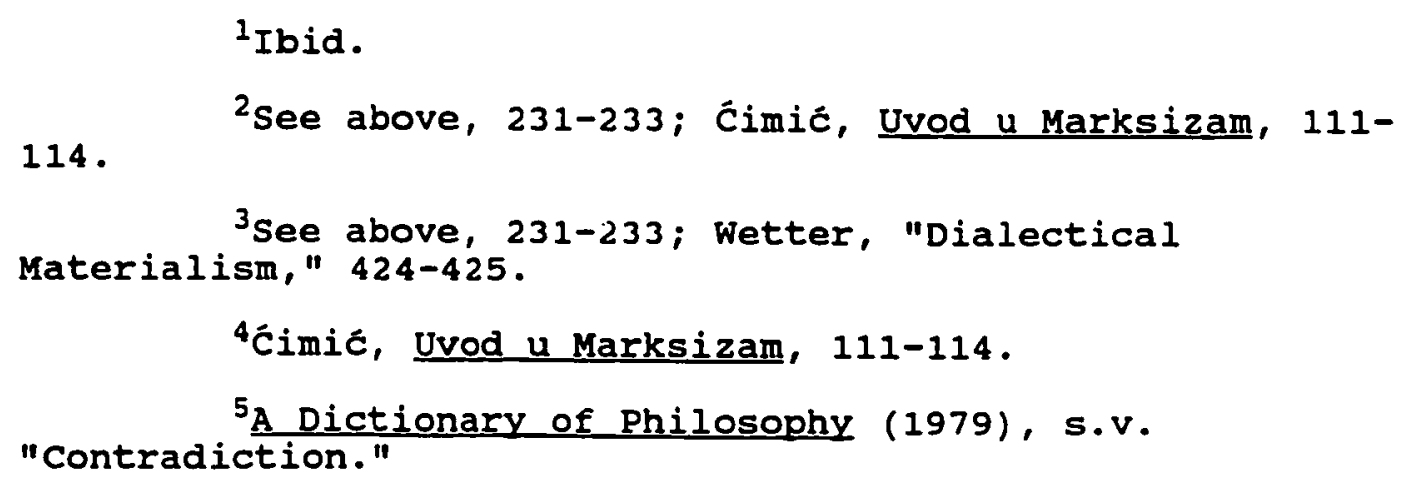


since non-dog does not actually exist; only the cat, the horse, or the three. ${ }^{1}$ Therefore, the kind of movement proposed by ćimic cannot be deduced from a "contradiction" without redefining the whole category of it. The term "struggle of opposites," on the other hand, applies to tensions and conflicts within or between physical things or social groups rather than to the logical questions. However, if movement within reality is to be explained by the struggle of classes (i.e., opposing elements within the reality), then the movement is explained by the means of movement itself without any attempt to explain the origin of the movement. 2

$$
\text { sixth, ćimić argues that by virtue of a change in }
$$

"productional forces," 3 the "relations of production" are able to change as well. That is, the development of scientific and technical means for the control of natural forces results in changes in "relations of production."4 In addition, Ćimić asserts that his work is empirical, that is, based on the facts of history and contemporary social

\footnotetext{
${ }^{1}$ Wetter, "Dialectical Materialism," 425.

2Ibid; see also A Dictionary of Philosophy, "Contradiction."

3The term "productional forces" is defined as the relation of man to the nature (see above, 27).

"The term "relations of production" denotes the mutual relations of men with each other in the process of production (ćimic, Uvod u Marksizam, 47-48; see above, 27).
} 
experience. ${ }^{1}$ Yet, history shows that although there was little or no technical progress between 200 B.C. and A.D. 700, some fundamental changes happened in the field of social relations. To some extent, these changes occurred under the influence of Christianity. ${ }^{2}$

Seventh, cimic considers praxis to be the criterion of truth. ${ }^{3}$ Although, the confirmation of an idea in practice can show the truth of the idea to some extent, praxis cannot be considered to be an ultimate criterion of truth. 4 The practical success of an idea has itself to be grasped by a mental act which must then be verified by some further norm. Therefore, in addition to praxis, it is necessary to find an ultimate criterion of truth. Without

IĆimic, Socijalisticko Društvo i Reliaija, 75.

${ }^{2}$ See Nicholas Lobkowicz, "Historical Materialism," Sacramentum Mundi, (1968), 3: 429. For instance, in the Hellenistic state the citizen was nothing except as a member of the state. His whole existence, including his religion, law, morals, art, science, acquisition and management of wealth, trade and industry were subject to and depended on the state. The state recognized neither moral nor legal limits to its power. With the spread of Christianity in Western Europe the social structure, and with it the theory of social relations, underwent profound modifications. Thus, already in the Roman Empire there developed an aspect of the state in which law began to some extent to be distinguished from state morality (Benjamin Kidd, "Sociology," The Encyclopaedia Britannica (1926), 25-26: $322-331)$.

${ }^{3}$ See above, 230; Ćimić, Drama Ateizacije, 46.

${ }^{4}$ Wetter, "Dialectical Materialism," 426. 
such a criterion one cannot escape a regressus in infinitum. ${ }^{1}$

After having evaluated some of the internal inconsistences in the theoretical base of cimie's philosophy, we intend now to discuss major points of conflict between his view and Christian-theistic conceptions.

\section{Evaluation of cimié's concept of Religion} from the Christian-Theistic Perspective

At this stage, it is our intention to look for those concepts in cimie's philosophy of religion which are closely related to theological issues and to evaluate them from the Christian-theistic perspective. Such aspects as major points of conflict and convergence between cimie's humanistMarxist point of view and the christian-theistic conceptions are included.

\section{Points of Conflict Between}

cimié's and Christian-

Theistic Conceptions

cimić's philosophy of religion is based on his atheistic presuppositions, and he operates mostly at the social and economic levels. Nonetheless, his concept of religion includes ideas which are related to theological issues, and on that basis it is possible to evaluate his view from the Christian-theistic perspective. Important

${ }^{1}$ Ibid. 
points of conflict ${ }^{1}$ include cimiés view of (1) religion in the future classless society, (2) man as a self-sufficient being, (3) alienation as the absence of praxis, (4) praxis as the criterion of truth, (5) philosophy of history, and (6) freedom as the possibility for realization of human abilities through work.

Religion in the Future classless society

It is not clear from cimic's writings what the real nature of religious faith is that will exist in the society liberated from socio-economic injustices. Cimic states that religion in the future classless society will be changed so drastically that it will hardly resemble the religion which existed in the conditions of class society. ${ }^{2}$ such religion will probably be "a poetic metaphor or a symbol of unflagging spirit." ${ }^{3}$

The Bible, in reference to the Christian religion or to religious faith, mentions at least three basic elements: (1) Faith in God involves right belief about him; ${ }^{4}$

${ }^{1}$ The points of conflict and convergence were chosen on the basis of my estimation of their importance for Cimic's concept of religion as well as their implications for Christian-theism. Atheism," 524 .

$$
\text { 2́imie, "Marx's Critique of Religion and/or }
$$

${ }^{3}$ See above, 210; Ćimic, Ateizam kao povijesni Humanizam, 65 .

$$
2: 13
$$

${ }^{4}$ See, for instance, Gal 1:8-9; Titus $1: 1 ; 2$ Thess 
faith's convictions are viewed in the Bible as certainties and as equal with knowledge--not because they originated from supposedly self-authenticating mystical experience but because they rest on the testimony of $\mathrm{God}^{1}$ and (3) Christian faith is a supernatural gift of God. ${ }^{2}$ Thus, it must be questioned whether ćimic's concept of religion in the future classless society defined as "a symbol of unflagging spirit" has anything in common with the biblical concept of religion. In fact, is it possible to call it religion at all? our response is negative.

Man as the Product of Nature and a Self-Sufficient Being

In ćimic's view, man is the product of nature and history. 3 He cannot be understood apart from his historical circumstances and his social relationships. 4 Man, as a self-sufficient being, creates and recreates himself through praxis. ${ }^{5}$ Although Cimic states that there are some elements in the structure of human nature which may be considered essential and universal, he always remains on

\footnotetext{
${ }^{1}$ Titus $1: 2 ; 1$ Cor $2: 10-13$.

2Eph 2:8; Phil 1:29. See also J. I. Packer, "Faith," Evangelical Dictionary of Theology, ed. Walter A. Elwell (Grand Rapids: Baker Book House, 1984), 399-402.

${ }^{3}$ Ćimić, Čovjek na Raskršču, 90-91.

4Idem, Ateizam kao Povijesni Humanizam, 52.

${ }^{5}$ See above, 226-227; Ćimic, Drama Ateizacije, 178 .
} 
the horizontal level ${ }^{I}$ and considers man's essentiaiity to be the result of the human historical experience. ${ }^{2}$ Thus, Ćimie actually denies completely anthropological

"essentialism" expressed in the biblical concept of man created in the "image of God." 3

The Bible ${ }^{4}$ recognizss that man is part of creation and that he is "total" only when his relationships with his neighbor are just and pure. ${ }^{5}$ However, Christianity, on the basis of biblical revelation, takes the Creator God, not man, as its point of departure. 6 Man, in the biblical perspective, is defined not in relation to nature nor to material and social forces, but primarily in terms of his

${ }^{1}$ See above, 227, 265-266.

2́imic, Ateizam kao Povijesni Humanizam, 61,62 .

${ }^{3}$ For further information, see kirk, "The Meaning of Man in the Debate Between Christianity and Marxism," 88 . The concept of the "image of God," according to Elien G. White, means that "man was to bear God's image, both in outward resemblance and in character" (Ellen G. White, Patriarchs and prophets [Mountain View: Pacific Press Publishing Association, 1913], 45). The whole man, that is, his body as well as his spiritual nature (his ability to exercise free will and to have self-conscious personality), is created in the image of God. The creation-image is conferred upon the whole human race ("Genesis," SDA Bible Commentary, ed. F. D. Nichol [Washington, D.C.: Review and Herald Pub. Assn., 1953-1957], 1: 216).

${ }^{4}$ We presuppose that the Christian-theistic view is identical with the biblical perspective. For that reason, as explained earlier, we use the terms "Christian-theistic" and "biblical" interchangeably.

$4: 25$.

${ }^{5}$ See Lev 19:18; Ps 15:3; Zech 8:17; Matt 19:19; Eph

${ }^{6}$ Faupel, 137. 
relationship to God. According to the creation account found in Genesis 1, man is creature and God is Creator. 1 Man is created in the image of God and as such he has a special place in God's creation. 2 Thus, the most basic biblical presupposition is that man owes his essence, his existence, his significance, and the meaning of his life to an infinite and personal God. ${ }^{3}$ This point of view is totally opposite to ćimie's concept of man.

In addition, ćimic argues that since there is no God, man is all there is and he is completely answerable to himself.4 Human autonomy or personal government of the direction of one's own life is the ultimate purpose of human existence. 5 Man creates himself, legislates by means of human reason, and decides how best he may pursue his own goals. 6 In the biblical view, however, it is precisely human independence from God which is equivalent to man's

\footnotetext{
IIbid. See also Kirk, "The Meaning of Man in the Debate Between Christianity and Marxism," 88 .

${ }^{2}$ Gen 1:27. Niebuhr writes: "The... important characteristic of the Christian view of man is that he is understood primarily from the standpoint of God. He is made in the "image of God'" (Reinhold Niebuhr, The Nature and Destiny of Man, 2 vols. [New York: Charles Scribner's Sons, 1943], 1: 33).

${ }^{3} \mathrm{~J}$. F. Butler and Chandran Devanesen, Communism and Christianity (Madras: Diocesan Press, 1980), 81-86.

4ćimic, Uvod u Marksizam, 66-67.

SIbid., 47 .

${ }^{6}$ Ibid.
} 
fallenness. 1 Man is seen as a created and finite being. ${ }^{2}$ The result of man's denial of his creatureliness is his false conception of himself as ultimate. ${ }^{3}$ Thus, ironically, what is considered by cimic to be the most important premise of true humanity is regarded by Christianity as the source of his sinfulness or alienation.

Alienation as the Absence of Praxis

Ćimic suggests that the essence of man's alienation is in the separation of the social phenomena (i.e., human work and products of that work) from his own control. 4 In other words, alienation is the absence of praxis which is

\footnotetext{
${ }^{1}$ David Lyon, "Evaluating Marxism: Some Christian Reflections," in Christianity and Marxism, ed. Alan Scarfe and Patrick Sookhdeo (Exeter: Paternoster Press, 1982), 134 .

${ }^{2}$ In this respect Niebuhr observes: "The whole import of the Christian doctrine of creation for the Christian view of man is really comprehended in the Christian concept of individuality. The individual is conceived of as a creature of infinite possibilities which cannot be fulfilled within terms of this temporal existence. But his salvation never means the complete destruction of his creatureliness and absorption into the divine. On the other hand, though finite individuality is never regarded as of itself evil, its finiteness, including the finiteness of the mind, is never obscured. The self, even in the highest reaches of its self-consciousness, is still the finite self, which must regard the pretensions of universality, to which idealistic philosophies, for instance, tempt, sin" (Niebuhr, 1: 181).

${ }^{3}$ Faupel, 139.

${ }^{4}$ See above, 157 ; Ćimić, Ateizam kao Povijesni Humanizam, 52 .
} 
dependent on the wholeness of social relations. 1 The solution to the problem of alienation lies in the establishment of a society in which man's interests would have the highest priority. ${ }^{2}$

Christianity, while realizing that some social environments are more conducive to harmony and peace of human mind than others, argues that no number of new social environments can offer a real solution for the problem of sin (alienation). ${ }^{3}$ on the basis of biblical revelation, Christianity holds that the concept of man as the image of God implies that man is created with the moral capacity to recognize the true nature of his creatureliness and his relationship to God. 4 However, it is this very capacity which allows man to rebel against his creatureliness and against his relationship with God. 5 It was also this moral faculty which found expression in the fall of man as described in Genesis 3. After the fall, man found himself in a predicament in which he is incapable of experiencing his true humanity because of the broken relationship with

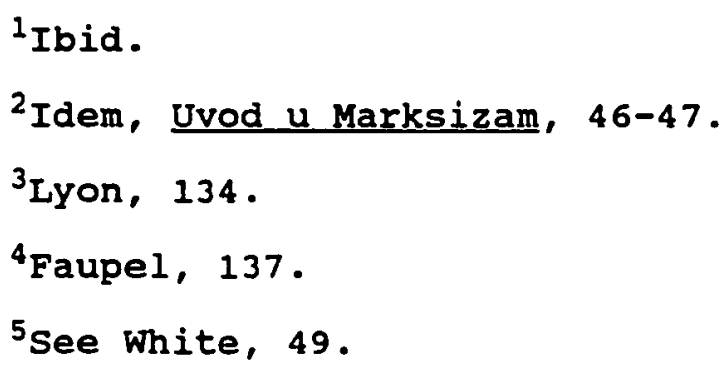


his Creator. ${ }^{1}$ Consequently, according to the Bible, all men are sinners. ${ }^{2}$

Christianity affirms, in opposition to cimie, that selfishness (sin) and the tendency to exploit others are not restricted to any one segment of mankind. ${ }^{3}$ The Christians do not believe that the elimination of class society and the establishment of a self-management society would eliminate injustice. Rather the problem is seen as much more deepseated. Man in general, not a particular class of men, is responsible for injustice. ${ }^{4}$

${ }^{1}$ Niebuhr writes: "The high estimate of hunan stature implied in the concept of 'image of God' stands in paradoxical juxtaposition to the low estimate of human virtue in Christian thought. Man is a sinner. His sin is defined as rebellion against God. The Christian estimate of human evil is so serious precisely because it places evil at the very center of human personality: in the will. The evil cannot be regarded complacently as the inevitable consequence of his finiteness or the fruit of his involvement in the contingencies and necessities of nature. sin is occasioned precisely by the fact that man refuses to admit his 'creatureliness' and to acknowledge himself as merely a member of the total unity of life. He pretends to be more than he is" (Niebuhr, 1:16).

${ }^{2}$ See Rom 3:23.

3The tendency to exploit others is restricted in cimic's philosophy mostly to the ruling class (bourgeois) in the capitalist, and to party bureaucrats in the socialist societies (ćimic, Uvod u Marksizam, 28-31).

${ }^{4}$ Harold Brown, Christianity and the class struggle (Grand Rapids: Zondervan Books, 1971), 28. In this respect Niebuhr asserts: "This fact (self-interest) which in Christian theology is regarded as the element of inevitable dishonesty in original sin, becomes in Marxism a tool of class conflict. It is used to transvalue the value of the dominant class and destroy their prestige. Marxism thus tentatively discovers and finally dissipates a valuable insight into human nature. It dissipates the insight 
Man's rebellion against his own state of created being, and hence against God, made him an alienated being with a perverted view of reality.1 The source of man's sinfulness is his rebellion against the relationship with God that lies in the very core of his being and not just in his natural impulses and rational faculties. 2 Because of this, it is necessary that God take initiative and break into man's world. The Bible contains many accounts of God breaking into human history. The climax appears to be the event of Christ's incarnation. ${ }^{3}$ At an individual level, God takes the initiative and enters into man's world through the "renewal of human mind."4 Thus, from the Christiantheistic perspective, this appears as the only solution to the problem of human alienation. 5

because it fails to recognize that there is an ideological element in all human rational processes which reveals itself not only in the spirituality of the dominant bourgeois class, and not only in the rationalization of economic interest, but which expresses itself in all classes and uses every circumstance, geographic, economic, and political, as an occasion for man's assertion of universal significance for his particular values. This defect of human life is too constitutional to be eliminated by a reorganization of society; a fact which constitutes the basic refutation of the utopian dreams of Marxism (Niebuhr, 1: 35).

\footnotetext{
${ }^{1}$ Faupel, 138.

${ }^{2}$ Ibid.

${ }^{3} \mathrm{Heb} 1: 1-3$.

"The Bible also uses the term "new birth" (see Rom 12:2; John $3: 5$ ).

${ }^{5}$ Butler and Devanesen, 85.
} 
Although the Bible views man as a sinner, it does not follow that he is worthless. Instead, man is considered to be of infinite worth. However, his worth is not the result of any human virtue. Man's value comes from the fact that he is God's creation and that God loves him.'

Praxis as the criterion of Truth

According to cimie, praxis is an activity of man through which he expresses his creative and adventurous (i.e., essential) being. Praxis is also viewed as the criterion of truth and value. ${ }^{2}$ Accordingly, those ideas and actions which contribute to the successful realization of praxis are considered true, while those ideas and actions which hinder this success are viewed as false. ${ }^{3}$

Christianity also asserts that man is a creative being ${ }^{4}$ and that consistency in theory and practice, that is, doctrine and life-style is vitally important. 5 However, Christianity does not rely for its source of truth and value on praxis. 6 For Christians, Jesus Christ as

${ }^{1}$ See Faupel, 138.

${ }^{2}$ See above, 230 ; Ćimić, Drama Ateizacije, 46, 178 .

${ }^{3}$ Ibid.

${ }^{4}$ Mojzes, Christian-Marxist Dialoque, 287 .

${ }^{5}$ See Lyon, 137.

${ }^{6} \mathrm{Kirk}$, "The Meaning of Man in the Debate Between Christianity and Marxism," 91. 
revealed in the prophetic and apostolic message of the Bible is The Truth. 1 Jesus, according to the biblical view, is The Truth because "he shares the qualities characteristic of God: constant, incorruptible, worthy of trust." 2 Further, He is the Truth because "he manifests in his word and person the saving reality of God which is Truth." 3 Thus, human justice makes sense only in the light of Christ himself who represents justice in his own person. 4 since the truth of revelation depends upon the God who reveals himself, it exists objectively and independently, whether or not it is believed and acted upon by man. 5 Nevertheless, it is legitimate that the genuineness of one's commitment to this truth be judged not simply on the basis of a profession of belief but by the practice of that truth. 6

${ }^{1}$ John $14: 6 ; 1: 14$; see Lyon, 136-139.

2T. M. McFadden, "Truth, Divine," Encyclopedic Dictionary of Religion (1979), O-z:3578.

${ }^{3}$ Ibid.

${ }^{4}$ Andrew Kirk, "Critique: Marx and the Bible," Sejourners 6 (1977): 35-37.

${ }^{5}$ Kirk, The Meaning of Man in the Debate Between Christianity and Marxism," 91.

${ }^{6}$ see Jas $2: 14-26$. At the root of cimic's philosophical system lies an affirmation that man's ideal is attainable through the medium of praxis. However, the criterion of praxis cannot be justified from praxis itself. Such an approach implies a faith in the final success of history, in the realizability of the ideal, which experience may confirm, but which remains anterior to experience. Thus, ćimic's assertion that religion is not true because it transcends experience is inconsistent with the fact that his concept of praxis (which is central to his philosophical 
Philosophy of History

Cimic asserts that history is the medium in which man creates society and establishes laws which regulate social relations. 1 The conflict of class interests represents the moving force and the internal dialectic of historical development. ${ }^{2}$ However, history is heading toward the establishment of a society in which the dialectical laws originating from socio-economic relations would not longer be valid. Instead, man would be the ultimate norm. ${ }^{3}$

Hence, ćimic, in common with Christians, affirms an ultimate goal and purpose of history. However, there are some major differences between ćimie's view of history and that espoused by Christians. Christianity does not maintain that the human mind possesses the capability of knowing the world process entirely. ${ }^{4}$ Christians also admit their

system) also transcends experience and requires faith in man and in an ideal (see Guilio Girardi, Marxism and Christianity [New York: Macmillan Company, 1968], 14-15; compare Ćimić, Drama Ateizacije, 46-47).

${ }^{1}$ See above, 231; Ćimić, Uvod u Marksizam, 111-112.

2 Ibid., 112 .

I'Ibid. , 112-113.

${ }^{4}$ In respect to the Marxist claim to complete knowledge of the process of history which will culminate in communism, Niebuhr writes: "The philosopher who imagines himself capable of stating the final truth merely because he has sufficient perspective upon past history to be able to detect previous philosophical errors is clearly the victim of the ignorance of his ignorance. Standing on a high pinnacle of history he forgets that this pinnacle also has a 
finiteness, their dependence, ${ }^{1}$ and thus acknowledge that the ultimate point of reference is not within their own mind or within the historical process. History is ultimately within God's control and because of that it is a meaningful process. ${ }^{2}$ Christian seeks, primarily, to live in obedience to God who acts in history. ${ }^{3}$ Man is a created being whose destiny is not merely within the historical process, but in the hands of God.4

Therefore, Ćimic understands history as the arena of dialectical struggle. The Christian understands history to be the sphere of God's activity. 5 Cimic argues that

particular locus and that his perspective will seem as partial to history as the pathetic parochialism of previous thinkers. Each great thinker makes the same mistake in turn, of imagining himself the final thinker. . . . Despite the tremendous contribution of Marxist thought in the discovery of the ideological taint in all culture, it is precisely the element of pretence which it fails to understand. Its too simple theory of human consciousness betrays it here" (Niebuhr, 1: 208).

${ }^{1}$ see Butler and Devanesen, 79 .

${ }^{2}$ Ibid.

${ }^{3}$ In this respect Richardson writes: "The Christian interpretation of history is derived from the Bible, which is essentially a book of history; that is to say, the Bible is a record of historical events whose meaning has been interpreted in terms of the activity and will of God through the insight of the prophets and apostles. - . Christianity is not itself a philosophy of history; it is rather the source of insights into the meaning of historical events which yields key-categories for the constructing of philosophies of history" (Alan Richardson, Christian Apologetics [London: S.C.M. Press, 1947], 108).

${ }^{4}$ Butler and Devanesen, 79.

${ }^{5}$ Ibid. , 80 . 
human reason will probably triumph over the oppressive socio-economic conditions which are the source of human alienation as well as over nature which is governed by laws arising out of its own volition. On the other hand, the Christian believes that such a perspective constitutes an overly optimistic view of human nature; ultimate victory over the sin and evil in this world is being thought of as possible only through the second coming of Christ. ${ }^{1}$ However, Christian understanding of history as the sphere of God's activity does not lead to blind and inescapable fatalism in regard to intelligent human beings' actions. Whereas fate is to be seen as impersonal power which overrules human freedom, divine providence "liberates man to fulfill the destiny for which he was created." 2 Providence means the realization of human beings' "authentic freedom through submission to divine guidance." 3 Consequently, human beings are truly capable of selfdetermination. ${ }^{4}$

\footnotetext{
${ }^{1} \operatorname{Rev} 20: 1-6$.

${ }^{2}$ D. G. Bloesch, "Fate, Fatalism," Evangelical Dictionary of Theology (1984), 407; see Rom 8:14-16.

${ }^{3}$ Bloesch, 407 .

4 Ibid.
} 
Freedom as the Realization

of Human Abilities

through work

According to cimic, man is free in the measure to which he is able to constantly and autonomously create new possibilities for the expansion of individual affirmation. ${ }^{1}$ In his view, this is possible only in a socialist, selfmanaging society. ${ }^{2}$ Thus, the criterion of human freedom is to be found in the realization of man's creative abilities through work. This represents the precondition for any real humanism. ${ }^{3}$

Although Christianity affirms the importance of work, 4 it rejects any notion of man being able to free himself through work. ${ }^{5}$ cimic's assumption that freedom flows from changed socio-economic conditions is inadequate from the Christian perspective. It can be argued that in order to change socio-economic conditions, freedom is needed as a precondition. 6 Alienated people are not able to struggle against alienation without, in their struggle,

\footnotetext{
1'́imié, Uvod u Marksizam, 48.

${ }^{2}$ See above, 236-239.

3́cimic, Uvod u Marksizam, 49.

${ }^{4}$ Mojzes, Christian-Marxist Dialogue in Eastern Europe, 316.

${ }^{5}$ See Faupel, 139.

"Jügen Moltmann, "The Revolution of Freedom," in Openings for Marxist-Christian Dialogue, ed. T. W. Ogletree (Nashville: Abingdon Press, 1968), 47-71.
} 
producing new alienations. 1 Man cannot free himself because he rebels by nature against his relationship to God. This relationship is considered to be the essence of his freedom. Hence, man can only be freed by the initiative of God, not by himself. 2

Therefore, cimic's philosophy of religion is based on his atheistic presuppositions and thus it includes some major points of conflict with Christian-theistic conceptions. Nevertheless, cimic must be given credit for creating a concept of religion which, in opposition to the dogmatic Marxist view of religion, has many positive implications for christianity. Thus, it is possible to find several important points of convergence between ćimiદ's and Christian-theistic conceptions.

\section{Points of Convergence between}

cimic's and Christian-

Theistic Conceptions

Some of the most important points of convergence between ćimic's and Christian-theistic conceptions, in my view, are: (1) a deep concern for the human being, (2) an emphasis on the importance of work for the wholistic development of man, (3) the view that human alienation may be partially caused by the oppressive socio-economic

\footnotetext{
IIbid.

${ }^{2}$ Faupel, 139.
} 
conditions, and (4) the rejection of the cyclical view of history.

Concern for the Human Being

The basic preoccupation that undergirds the whole of cimic's philosophical system is the concept of freedom of human beings from all alienation. ${ }^{1}$ For cimic, man is the highest being and consequently he must be taken seriously. Every effort of humanity should be directed toward the establishment of those socio-economic conditions which would allow the realization of man's creative abilities. ${ }^{2}$

Although, for the Christian, man is not the highest being, yet, he is considered to be of high importance. ${ }^{3}$

\footnotetext{
${ }^{1}$ See above, 103; Ćimić, Ateizam kao Povijesni Humanizam, 61-83; Drama Ateizacije, 197-203; Dogma i Sloboda, 197-203.

2 Ibid, Uvod u Marksizam, 48.

${ }^{3}$ See Mojzes, Christian-Marxist Dialoque in Eastern Europe, 268. Hromadka writes: "The gospel reminds us constantly that we cannot believe in God if we do not see man before us, that we cannot love God without loving man and that the actual meaning of faith is the liberation of man from his own Ego, for service, for brotherly love, and for full solidarity with people in their sin and suffering, humility and struggle for a new life... . Christians themselves often distorted the true teaching of the Gospel, with their spiritual egoism and false longings for heavenly bliss after death. The real and mighty message about the kingdom of God and eternal life is a message that God wishes to rule here in this world in truth and justice, in love and forgiveness. Eternal life is the victory of God here among us. Whoever has believed in Jesus of Nazareth has eternal life here, it is here that he is freed, from his own ego and from fear of men, it is here that he can, with joy and hope, perform his tasks and fulfill his destiny" (Josef Hromadka, "On the Threshold of a Dialogue," Communio Viatorum 7
} 
Man is of infinite value because he is the product of divine creation and recipient of God's love.' one of the most important biblical teachings is that a christian must not be concerned only about himself but must care for the poor and oppressed since it is not possible to love God without loving man. 2 Therefore, Christian humanism along with cimie's brand of humanism is concerned with overcoming human alienation and the reconciliation of men in communities of love and justice. ${ }^{3}$ However, Christians are also aware that by nature people are sinful, unable to love, or to do justice. Therefore, they feel dependant upon God's transforming power in order to overcome their personal and social alienation. 4

The Importance of Work for Human Development

For Ćimic, man is above all a being of praxis 5 who expresses his creative and imaginative abilities through work. Because of that it is necessary to create such social

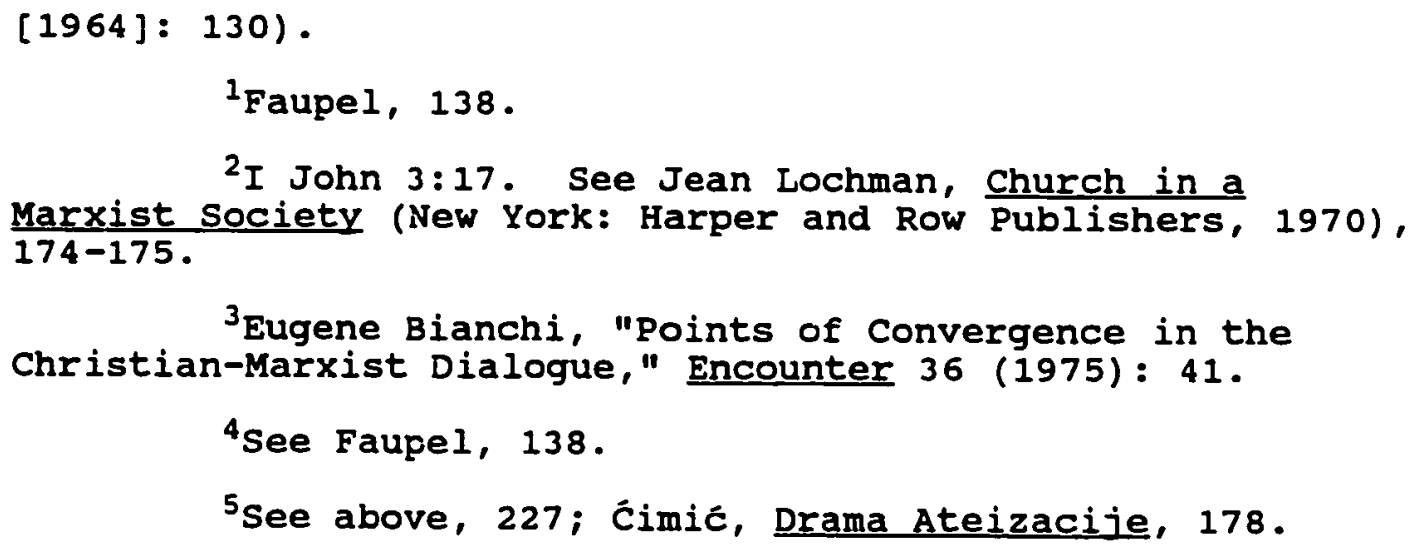
174-175.

${ }^{3}$ Eugene Bianchi, "Points of Convergence in the Christian-Marxist Dialogue," Encounter 36 (1975): 41.

${ }^{4}$ See Faupel, 138.

${ }^{5}$ See above, 227 ; Ćimić, Drama Ateizacije, 178. 
conditions in which work would become more and more a means for realization of human praxis. 1

According to the Bible, man was created to work and to dominate the whole creation because the earth was created, in part, for him. ${ }^{2}$ Through work, man was designed to express his creative and artistic capabilities. ${ }^{3}$

However, the Bible also emphasizes that man's sin has corrupted and degraded work. 4 In spite of this fact, even sinful man possesses such great gifts and abilities that he can subdue and use the physical world as well as realizing his artistic talents. 5 Honest work is important not only for man himself, but it is to be performed as a divinely given commission to God's eternal glory. 6

The Social Aspect of Alienation

Ćimić mentions several sources of man's alienation. ${ }^{7}$ However, he claims that the essence of man's

\section{${ }^{1}$ Ibid.}

${ }^{2}$ Gen $1: 28$; Gen 2:15. See also Kirk, "The Meaning of Man in the Debate between Christianity and Marxism," 85 .

${ }^{3}$ Ibid; for further information, see Mojzes, Christian-Marxist Dialogue in Eastern Europe, 316-319.

${ }^{4}$ Gen $3: 17-18$.

${ }^{5}$ See Exod 31:1-11; Exod 36:1.

${ }^{6}$ Rev 14:13. See also W. S. Reid, "Work," Evangelical Dictionary of Theology (1984), 1188-1189.

${ }^{7}$ See above, 154-174. 
alienation is to be found in the separation of man's work and its products from his own power and control. ${ }^{1}$ Man is alienated when socio-economic forces become an autonomous power, functioning on the basis of their own laws and independently of human will.2

Although the Bible considers man's broken relationship with God as the essential source of man's alienation, it does agree, nevertheless, with cimic's assertion that a part of man's alienation is caused by the domination and oppression of man through work. ${ }^{3}$ For instance, the Bible mentions the case of the Hebrews in Egypt who were subjected to such oppression that their "lives were bitter" ; prophets emphatically condemned the social injustices $i^{5}$ James warns the rich oppressors. 6 Work from the Christian standpoint is never a means of acquiring power or influence, but rather means of service

1'́imic, Ateizam kao Povijesni Humanizam, 52.

2 Ibid.

${ }^{3}$ kirk, "The Meaning of Man in the Debate between Christianity and Marxism," 85; "Critique: Marx and the Bible," 35-37.

${ }^{4}$ Exod 1:11-14; Exod 5:4-19. Mic 2:1-2.

${ }^{5}$ Isa $10: 1$; Isa $58: 3-4$; Jer $22: 13-17$; Amos 2:6-7;

6 Jas $3: 1-6$ 
toward one's neighbor. ${ }^{1}$ Anything less, and work becomes a partial cause of human alienation.

The Rejection of the Cyclical

View of History

on the basis of the internal dialectic of reality, ćimic argues that history is going forward toward a certain goal. ${ }^{2}$ He rejects the cyclical view of history. ${ }^{3}$ He also asserts that the creator of history is man himself $f^{4}$ who with other men establishes the laws which regulate social relations. 5

It is the Bible, however, that has given the world the idea of linear history. ${ }^{6}$ The Bible rejects all kinds

${ }^{1}$ Phil 4:14-18; see also Kirk, "The Meaning of Man in the Debate between Christianity and Marxism," 85 .

${ }^{2}$ See above, 233; Ćimic, Uvod u Marksizam, 45-46.

${ }^{3}$ The cyclical view of history had its beginnings in Chaldean astronomy. It is an explanation of events and their repetition through predictable seasonal changes. The same view was later found in the writings of Herodotus, Empedocles, Plato, Aristotle, Seneca, and Nietzsche. Augustine rejected this view and held that the source of history is God's creative act which continues to sustain the world and which moves the world toward a divinely appointed goal (F. H. Brigham, "History, Philosophy of," Encyclopedic Dictionary of Religion [1979], F-N: 1676).

${ }^{4}$ see above, 231.

5́́imić, Coviek na Raskršću, 16.

${ }^{6}$ The biblical concept of time is not purely linear in the sense of referring only to the terminal point of the line. Rather, the Bible speaks rather of a recurring pattern in which divine judgment and redemption interact until the pattern attains its definitive manifestation (see F. F. Bruce, "Eschatology," Evangelical Dictionary of Theology [1984], 362-365). 
of nature religion with their cyclical understanding of history and asserts, instead, God's purpose in history. ${ }^{1}$ Moreover, in the biblical view, man is a historical being. Abraham, for instance, was responsible for some fundamental changes in world history through his acts of willing obedience to God. ${ }^{2}$ Therefore, the Bible rejects all kinds of historical determinism and fatalism, asserting that man in collaboration with God is the subject and not just the object of history. ${ }^{3}$

\section{Summary}

In the first part of this chapter, I attempted to evaluate ćimic's concept of religion from the dogmatic Marxist perspective. In its entirety, cimic's work represents a condemnation and rejection of the dogmatic Marxist concept of religion. However, it is still possible to observe some elements in his philosophy which remind us of the dogmatic Marxist approach. For instance, cimic emphasizes the influence of socio-economic factors at the expense of onto-anthropo-psychological aspects. Then, cimić

${ }^{1}$ Kirk, "The Meaning of Man in the Debate between Christianity and Marxism," 85.

${ }^{2}$ For instance, Abraham willingly obeyed God and left his homeland to go to the land of Canaan. There, God entered into a covenant with him and he become the progenitor of the Hebrew nation and of several Arabic peoples (Gen 12:1-3; Gen 15:12-21; Heb 11:8).

${ }^{3}$ See N. L. Geisler, "Freedom, Free Will, and Determinism," Evangelical Dictionary of Theology (1984), 428-430. 
303

suggests that certain kinds of knowledge may produce the "light of consciousness," and thus, at least partially, liberate man from the religious illusion. Again, atheism in Cimic's view represents the "rational standpoint based on scientifically proven facts" and "demystified consciousness" which will be realized in the future classless society. These elements are evidences that there are still some remnants of the enlightenment-rationalistic approach in ćimic's theory of religion.

still, all these inconsistencies and similarities with dogmatic Marxist ideas must be considered secondary when compared with cimie's humanistic ideas which stand in direct opposition to the dogmatic Marxist philosophy of religion. For example, contrary to the unimaginative dogmatic Marxist approach to religion, ćimić introduces a new, creative approach in Yugoslav philosophy of religion. Then, contrary to the dogmatic Marxist assertion that Marx's work represents an infallible, all-inclusive norm, ćimic argues that Marx's critical philosophy is not to be considered as final and perfect. Again, Ćimic condemns and rejects the enlightenment-rationalistic, spontaneouseconomic, and administrative concepts of religion. In his view, Marxist humanism must struggle to create social conditions in which freedom of consciousness of all kinds, including religious freedom, may be expressed. Further, contrary to the dogmatic Marxist assertion that religion is 
a simple phenomenon caused by oppressive economic conditions, ćimie argues that religion is a multi-faceted phenomenon resulting from many influences within the totality of reality. In addition, contrary to the dogmatic Marxist assertion that science stands in opposition and has triumphed over religion, ćimic argues that science and religion are disparate forms of "spirit" which do not really intersect because the objects of their interest are different. Finally, while dogmatic Marxism asserts that religion will disappear with the abolition of class society, Ćimić argues that in spite of the abolition of oppressive economic conditions, religion will probably always exist. Consequently, it is possible to conclude that in spite of some remnants of the dogmatic Marxist criticism of religion in Cimie's philosophy, his humanistic reconceptualized view of religion is, in many of its aspects, totally opposite to dogmatic Marxist notion of religion. He has formulated a different approach toward the religious phenomenon which has had far reaching consequences for Marxists as well as Christians.

In the second part of this chapter we have evaluated some internal inconsistencies in the theoretical base of ćimić's philosophy which may contribute to a clearer and more comprehensive understanding of major points of conflict and convergence between his and Christian-theistic conceptions. For instance, although ćimić claims to be a 
materialist, it seems that he vacillates between materialism and idealism. Then, cimic states that religion is basically a product of human psyche caused by man's social dependence as well as by his wishes. However, although nothing exists because we wish it, it is not true that something cannot exist because we wish it. Again, Ćimic's assertion that socio-economic conditions are the essential factors in the creation of human consciousness does not take account of the fact that there are diverse, even opposite ideas, produced by a human mind. Further, in his attempt to denounce the existence of God and the creation of the world, cimic holds to the presupposition of the eternity of the world. However, the classical proofs for the existence of God, on the other hand, do not rest on the temporal origin of the world. Rather, they are deduced from the fact that the world is contingent. In addition, cimic's view of the movement of history does not appear to be entirely logical. He explains the movement by the movement itself (the struggle of classes), neglecting to explain the origin of the movement as such. still, cimic's assertion that by a change in productional forces the relations of production will also change seems to be contradicted by historical evidences. Finally, Cimic's idea that praxis is the ultimate criterion of truth is contradicted by the fact that the practical success of an idea must be grasped through a mental act which in its turn must be verified by some 
further norm. Thus, if a regressus in infinitum is to be avoided, it is necessary to find an ultimate criterion for truth.

In addition to internal contradictions in the thought of ćimic, we have evaluated some major points of conflict between ćimic's views and those of Christiantheism. For instance, Cimic's concept of religion in the future, classless society defined by him as "a poetic metaphor or a the symbol of unflagging spirit,"1 has nothing in common with the biblical concept of religion. Then, Cimic's denial of every kind of anthropological essentialism seems to be in contradiction with the biblical concept of man created in the "image of God." Again, in ćimic's view, the essential source of human alienation is to be found in oppressive socio-economic conditions. Contrary to this theory, the Bible asserts that the source of man's sinfulness lies in the fact that man has rebelled against God his Creator, thereby breaking his relationship with Him. Further, the source of truth, for cimic, is in human praxis. By contrast, the source of truth for Christians is found in the prophetic and apostolic messages. In fact, Jesus Christ is "the Truth." 2 In addition, while cimic understands history to be the arena of dialectical struggle,

\footnotetext{
'Ćimie, "Marx's Critique of Religion and/or Atheism," 524.

2 John $14: 6$.
} 
Christianity believes history to be the sphere of God's activity. Lastly, Ċimic's assertion that human freedom flows from changed socio-economic conditions is considered, by Christians, to be inadequate. They argue, on the basis of biblical revelation, that the source of human freedom is found in a relationship with God.

There also appear to be some points of convergence between Ćimié's perspective and that of Christian-theism. For instance, there is a deep concern for the well being of man in cimić's philosophy. Man is viewed as the highest being. For Christians, although man is not the highest being, he is of infinite value due to the fact that he is God's creation. Then, ćimie emphasizes the need of man to express his creative abilities through work. The Bible also emphasizes that man was created to work, so realizing his artistic and imaginative talents. Still, along with cimić, the Bible emphasizes that a large part of man's alienation is the result of the dominion and oppression of man through work. In addition, ćimić rejects the cyclical view of history, asserting that because of human action history is moving toward a certain goal. For Christians, history also has a purpose and is moving forward.

As indicated just above, the evaluation of cimic's concept of religion from the Christian-theistic perspective reveals that there are some internal inconsistencies in his theoretical thought as well as several points of conflict 
and convergence between his views and the Christian-theistic perspective. In my view, we cannot overestimate the significance of these common ideas shared by both cimic and Christians as well as of his other reconceptualized humanist-Marxists concepts. Both of these aspects have contributed to better relations between Christians and Marxists in Yugoslavia and other Eastern European countries at a time when there was little or no hope for improvement of mutual relations.

We now turn to the final stage of our study, that is, a general conclusion and assessment of ćimićs concept of religion. 
CHAPTER VII

GENERAL CONCLUSION

At the beginning of this study I posed the following questions: (1) How does ćimic reconceptualize the dogmatic Marxist concept of religion and can he still be considered a Marxist? (2) How does his reconceptualized concept of religion relate to Christianity? and (3) what is the significance of his reconceptualization for both dogmatic Marxism and Christianity? The search for an answer to these questions required the description and analysis of the general background of dogmatic and humanist Marxism, ćimic's life and the theoretical basis of his thought, cimic's reconceptualization of the dogmatic Marxist criticism of religion, and his own humanist-Marxist concept of religion. On the basis of our analysis and evaluation of cimie's concept of religion, it is possible to affirm, in respect to the first question, that cimic's reconceptualization involves the rejection of most aspects of dogmatic Marxism. For instance, he criticized the dogmatic Marxist sterile statements about religion, rejected their claim that Marxism is to be seen as an all-inclusive worldview, opposed their concepts of religion used in 
socialist countries, and repudiated their contention that religion as a simple reflection of the existing oppressive socio-economic conditions and as opposed to science will completely disappear in the future communist society. ${ }^{1}$ However, ćimic has also retained some features of dogmatic Marxism such as an emphasis on the prime importance of the socio-economic conditions for the creation of religious ideas, the idea of the possibility of "light of consciousness" in religious people, and the concept of atheism as "demystified consciousness."2 Therefore, cimic is to be viewed as a Marxist-revisionist who takes into consideration continuities and discontinuities with his Marxist roots. 3

Moreover, ćimić also attempts to take account of new empirical evidences in relation to religion. ${ }^{4}$ Thus, he is

${ }^{1}$ For the detailed description of the elements of the dogmatic Marxist criticism of religion that ćimić has reshaped, opposed, and even rejected, see above, 257-271; see also skledar and Kukoc, 7; Ćimic, Ateizam kao Povijesni Humanizam, $27,34,38,52-53,54-55,63-64,70$; Kukoð, review of Drama Ateizacije, by Esad ćimic, 605-607).

${ }^{2}$ For the detailed analysis of the features of dogmatic Marxism that Ćimic has retained, see above, 246256; see also Skledar and Kukoc, 7 ; Ćimic, Ateizam kao Povijesni Humanizam, $27,34,38,52-53,54-55,63-64,70$; Kukox, review of Drama Ateizacije, by Esad ćimić, 605-607).

"The term "revisionism" describes various revisions, additions, and developments of Marx's teachings after his death. It is generally used by dogmatic Marxists to designate "heretics" in Marxism (Werner Post, "Marxism," Sacramentum Mundi (1968), 3:420).

$$
{ }^{4} \text { Ćimiés letter, } 1990 .
$$


also to be considered a post-Marxist ${ }^{1}$ in that his philosophy goes beyond the confines of the Marxist understanding of religion in some respects. For instance, Cimic has rejected the dogmatic Marxist assertion that Marx and other classics of Marxism have developed an infallible worldview. For him, nothing in Marx's philosophy is to be thought of as final and perfect. Rather, Marx is portrayed as merely giving hints regarding various phenomena. Accordingly, religion should not be approached with some a prioristic ideas in mind. Instead, ćimie recommends a creative and objective approach which takes into consideration all the empirical evidences that might help us in our understanding of it. Accordingly, ćimic's concept of religion "per se" and religion as "anthropo-psychological structure" are not based exclusively on the Marx's philosophy but on ćimic's personal empirical research as well. 2

'In stojanovie's view, if cimic were only revisionist it would mean that he has reinterpreted some aspects of the dogmatic Marxist criticism of religion but has basically remained within the confines of it. PostMarxism, on the other hand, does not mean the absence of or even anti-Marxism. Rather, it is a philosophy which takes into consideration fundamental continuities as well as the basic discontinuities with its roots. In other words, although Cimic does not neglect his Marxist roots, he also affirms the importance of the empirical evidences which have emerged in the meantime (see svetozar stojanovic, Lawrence, Kansas, Letter to Radiša Antic, Berrien Springs, December 6 , 1989).

${ }^{2}$ See above, 191, 222 ; Ćimic, Ateizam kao Povijesni Humanizam, 66 . 
In respect to the second question, our analysis and evaluation of ćimie's concept of religion from the Christian-theistic perspective has revealed his work to be of signal importance with manifold implications of his work for christianity. There are elements in ćimic's philosophy of religion which stand in opposition to what Christians believe, such as, his concept of religion in the future classless society, his understanding of man as the product of nature and a self-sufficient being, his concept of alienation as the absence of praxis, his claim that praxis is the criterion of truth, and his philosophy of history. 1

However, there are also points of convergence between ćimié's perspective and that of Christian-theism. Cimic shares the same view with Christians in his concern for the human being, in his emphasis on the importance of work for human development, in his claim that oppressive social conditions play an important role in human alienation, and in his rejection of the cyclical view of history. ${ }^{2}$

${ }^{1}$ For the detailed description of the points of conflict between cimic's and Christian theistic conceptions, see above, 281-295; see also Packer, 399-402; Butler and Devanesen, 85; Faupel, 139; Ćimic, Drama Ateizacije, 178; Uvod u Marksizam, 46-47, 49.

${ }^{2}$ For the detailed analysis of the points of convergence between ćimic's perspective and that of Christian-theism, see above, 296-301; see also Mojzes, Christian-Marxist Dialoque in Eastern Europe, 268; Reid, 1188-1189; Kirk, "The Meaning of Man in the Debate between Christianity and Marxism," 85; Ćimić, Ateizam kao Povijesni Humanizam, 52; Čovjek na Raskršču, 16. 
Additionally, cimic's work presents a challenge to biblically based christians to change their attitudes in regard to social ethics, justice, and their raison d'ettre. For instance, Christians should realize that it is not enough to merely observe and interpret humanity. It is also necessary to be involved in practical actions which can produce changes in society for the betterment of humankind. ${ }^{1}$ Then, Ćimic's emphasis on the seriousness of human alienation as caused by various social sources in the contemporary world reminds Christians of their social responsibilities and duties. ${ }^{2}$ Again, Christians may be inspired by ćimić's work to develop a greater appreciation for the importance of the temporal reality and for human cocreators of that reality. In addition, in today's Yugoslavia, which is divided by the nationalistic-religious hatred, cimic's contention that religion was and is continually misused in the interest of naked political power instead of dealing with the individual human needs finds its full justification and may serve as a warning to all Christians. ${ }^{3}$

Third, what can be said in regard to significance of ćimié's reconceptualization of dogmatic Marxist criticism of

\footnotetext{
${ }^{1}$ see above, 229-230.

İid., 158-176.

3Ibid., 195-201, 205-207; see Mojzes, "The Rehabilitation of Religion in the U.S.S.R. and Eastern
} Europe," 16. 
religion for both dogmatic Marxism and Christianity? During the many years of oppression and persecution of religious people in the communist countries, cimic as well as some other humanist Marxists ${ }^{1}$ dared to oppose the theories and methods of dogmatic Marxists. Thus, for instance, ćimic has contended that the violent efforts to eliminate religion are merely attempts to institute an aggressive secular religion. 2 Then, in his view, the administrative liquidation of religion creates spiritual bankruptcy and leaves people unprepared for functioning in contemporary society. ${ }^{3}$ Again, Ćimic has asserted that in our era of loneliness and individualism, religion may activate affirmations of collective values and norms and thus be a mode of humanization which serves a progressive role. Finally, Ćimić emphasized the importance of dialogue between Marxists and Christians. In his view, the most important dialogue is between believers and non-believers in the process of self-management and not between the leaders of the church and state. 4 In most cases, as a consequence, ćimić and other humanist Marxists have paid a heavy price for their outspokenness. Yet, their sincere search for

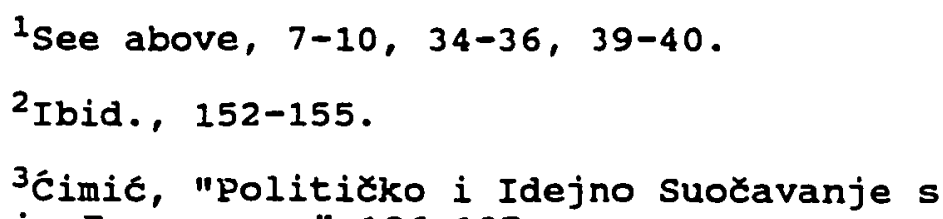

${ }^{4}$ Ibid. See also Mojzes, "Christian-Marxists Encounter in the Context of Socialist Society," 16-17. 
"truth" and their readiness to defend it can now be seen as one of the important causes for the recent dramatic changes which brought about the downfall of dogmatic Marxism in Eastern Europe. I maintain, therefore, that the most important significance of cimie's philosophy of religion is to be seen in the limited ${ }^{1}$ but important role it has played in the almost complete collapse of the dogmatic Marxist criticism of religion in Eastern Europe and in the establishment of more humane conditions in which people can freely practice their religious belief. 2

Through his work, Ćimić has made a significant contribution to the creation of new conditions of religious freedom in Yugoslavia as well as in other countries. ${ }^{3}$ stojanovic describes how, in our own day, Gorbachev has implicitly admitted to the pope the primitiveness of the dogmatic Marxist attitude toward religion. Cimic should be regarded, stojanovic remarks, as a "forerunner of the present changes" in Eastern Europe. In addition, stojanovic contends that even people like Gorbachev need to catch up

In addition to the humanist Marxism, there are other factors which contributed to the breakdown of dogmatic Marxism in communist countries, such as the collapse of economic system, the shortage of basic goods, and the lack of freedom of expression. These factors have caused a widespread dissatisfaction in people.

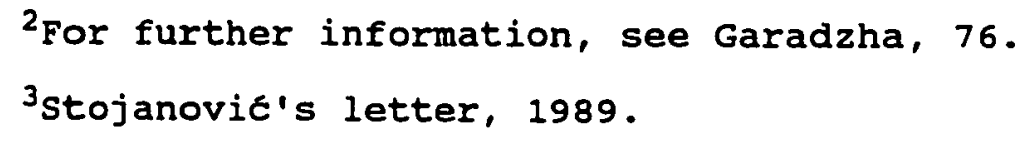


with Ćimic's understanding of the religious phenomenon. 1 We may note a few examples of concrete changes in Eastern Europe which are partly the result of the emerging humanist Marxist benevolence toward religion. For instance, in the Yugoslavia of 1991, religion is constantly present in the public eye. People openly discuss and express their religious beliefs and interests. ${ }^{2}$ In the Soviet Union the changes in attitude towards religion have come unexpectedly and have created a heady atmosphere of freedom. The churches receive public recognition, monasteries are being returned to active use, the media recognizes religion as a part of daily life. ${ }^{3}$ In Hungary in 1991, it is almost impossible to find any trace of dogmatic Marxist tradition. 4 Not since the Communist Revolution in 1917 have there been such remarkable changes in regard to religion. Dogmatic Marxists admit their errors in their previous assessment of religion and blame stalin and Lenin for suppression of religious freedom. They acknowledge that the suppression of religion caused damage to the moral climate and provoked spiritual malaise of their societies. 5

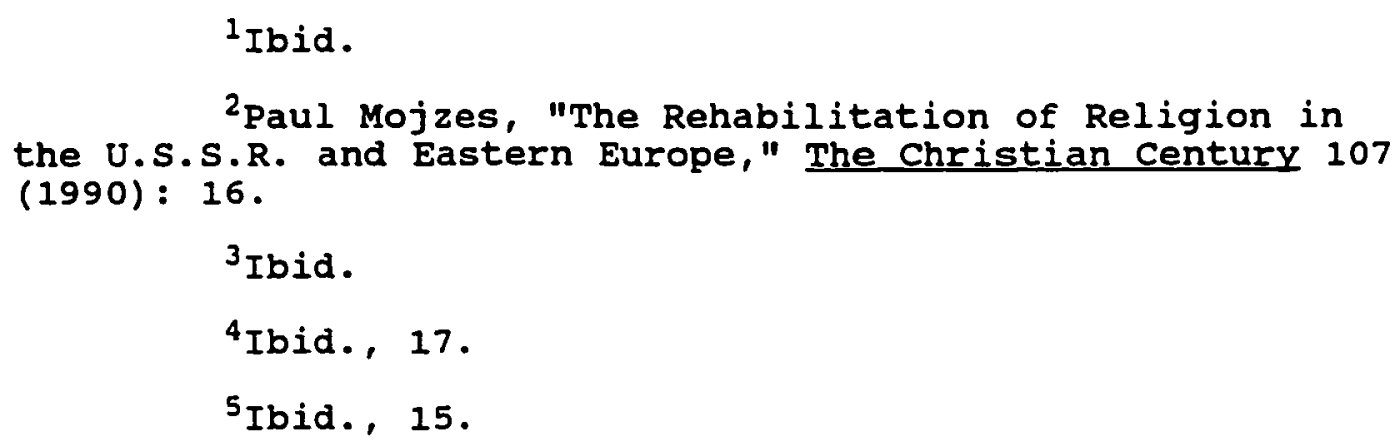


ćimic's criticism of dogmatism in Marxism, in my view, has played an important role in these changes.

The significance of cimic's reconceptualization of dogmatic Marxist philosophy should be seen not only in light of the past and the present. His humanist views, such as his deep concern for the well being of people, his emphasis on the seriousness of the social alienation of man, his stress on the need to change erratic social conditions, his accentuation of work for the harmonious development of human beings, and his contention that only freedom can liberate man from alienation, these may all pave the way for the development of a different and more acceptable Marxism in the future. An indication of this possibility is seen in the experience of the Communist Party in Serbia. This Party changed its name to the Socialist Party, adopted nondogmatic humanist Marxist ideas, and subsequently won power in free elections. This development portends that in the future some forms of humanist Marxism may be more attractive to voters than common capitalist forms of society.

However, from my Christian-theistic perspective, the world is coming to the realization that all human ideologies are bankrupt. ${ }^{1}$ Communism was considered by many to be "an ideal of human participatory community in which all goods are shared, all persons are equally valued and human need

${ }^{1}$ See Charles West, "Joseph Hromadka and the Witness of the Church in East and West Today," The Princeton Seminary Bulletin 11 (1990): 44-45. 
has priority over human greed. . . "I But the world has watched socialist systems disintegrate, unable to produce the basic goods people need. On the other hand, capitalists in the West rejoice that their theory about the laws of the free market seems to be justified by its results. However, capitalism in its purest form centers its concern in profits, not people, and thus faces a continuing dilemma of social inequalities, injustices, and poverty of certain social groups. In order to keep capitalist economy competitive, it may require "a degree of social control that would make a mockery of [capitalism's] one claimed virtue: freedom."2 Thus, it seems that the principles of concern for human dignity and the freedom to make a profit are contradictory to one another. Therefore, in my view, neither system has developed a viable human society for tomorrow. The real and ultimate solution for this world's problems must come from outside of this planet, from God. As mentioned in chapter one, it must be recognized that this study is somewhat limited in scope and does not encompass all aspects of ćimic's view of religion. For this reason and as a result of the findings of this dissertation, other ideas can be suggested for further investigation. For instance, why do other Yugoslav humanist Marxist philosophers, such as Kerševan and skledar, go further in

\footnotetext{
${ }^{1}$ Ibid.

${ }^{2}$ Ibid., 44 .
} 
their rejection of the dogmatic Marxist criticism of religion by declaring that religion is not an alienation at all but a special social practice through which human beings receive what they do not have? What are the factors that prevent ćimić from embracing a more favorable position toward religion? In order to be able to answer these questions, it would be necessary to critically analyze and correlate ćimic's view of religion with the views of Kerševan or skledar. Furthermore, in view of the fact that this study analyzed cimic's view of religion in the context of Eastern Europe, a further step would be to compare his philosophical ideas with West European versions of reconceptualized Marxist concept of religion in order to determine points where their views intersect and where they diverge. 


\section{BIBLIOGRAPHY}

\section{Primary Sources}

Ćimic, Esad. "Aktuelnost Lenjinovog Odnosa Spram Religije." život 19 (1970): 35-43.

- "Aktuelnost Marksove Misli." odjek 27 (1974): $12-26$.

- "Ali Drugog Puta Nema: Uvod u Misao Drugog

Vatikanskog Koncila." Pogledi 2 (1971): 133-138.

"Ateizam i Religija." Sociologija 12 (1970):

$387-397$.

- Ateizam kao Povjesni Humanizam. Zagreb: Školske Novine, 1988 .

- "Ateizam u Teoriji i Praksi Savremenog

Socijalizma." Gledišta 5 (1964): 1143-1151.

- Belgrade, Letter to Radiša Antic, Berrien

Springs, May 22, 1989.

- Belgrade, Letter to Radiša Antić, Berrien Springs, January 6, 1990.

- Covjek na Raskršču. Sarajevo: Svjetlost, 1975.

- Dogma i Sloboda: Otvoreno Društvo i Zatvorena

Misao. Belgrade: Niro "KnjiZevne Novine", 1985.

- Drama Ateizacije. Belgrade: "Srboštampa", 1984.

- Društvo i Religija: Marksisticka Kritika

Religije. Belgrade: RadniCki Univerzitet "Djuro Salaj," 1962 .

"Drzava i Konfesionalne Zajednice u Jugoslaviji." Politicka Misao 4 (1967): 155-165.

"Duhovno Raskršce." Lica, April 1968, 1-3.
- "Duhovno Raskršće Mladih." Odjek 23 (1970): 4-6. 320 
"Fenomenologija Poltrona u Jugoslovenskom Drustvu." obeležja 2 (1971): 1-9.

"klerikalizam i Antiklerikalizam." Gledišta 16 $(1975)$ : 497-513.

"Kriticka Svijest o Smislu Dialoga Izmedju Komunista i Teista." Komunist, October 1966, 15-17. "I Vjernici su Samupravljaci." Danas 1 (1982): 13-16. - "Marx's Critique of Religion and/or Atheism." Journal of Ecumenical studies 3 (1985): 519-52.4. - "Mladi i Religija." Revija 7 (1967): 91-97.

- "Mogućnosti Marksistickog Pristupa Fenomenu Religije." In Religija i Društvo, ed. Siniša Zrinšak, 28-45. Zagreb: Edicija Centra za IdejnoTeorijski Rad, 1987.

- "Moral Izmedju Religije i Ateizma." Encyclopedia Moderna 7 (1972): 23-29.

- "Nacija u Svetlu Sociološke Analize."

Sociologija 11 (1969): 389-415.

"(Ne) Zaboravljeni Bog." In Covjek od Straha, 52-69. Belgrade, Ljubljana: Partizanska Knjiga, 1986 .

- "Nije Religija Dobra Nauka, vec je Nauka Dobra Religija." Telegram, January 1969, 12-15. "Odgojna Funkcija Škole i Religija." Pogledi 2 (1971): 83-101.

- "Odgojno--Obrazovni Proces i Religija: Prilog Kritici Domacih Udzbenika iz Sociologije." Pogledi 11 (1981): 43-59.

"Odsustvo Vjere u Sebe Trazi vjeru u Boga." Odjek 18 (1964): 17-42. Omladina i Religija. Belgrade: Narodna Armija, 1967.

- Osnovi Nauke o Društru. Sarajevo: Svijetlost, 1976. 
- "Pedagog i Religija." Sociološki Pregled, January 1970, 3-20.

- "Politicko i Idejno SuoCavanje s Religiskim Fenomenom." In Religija i Društvo, ed. Vjekoslav Mikecin, 183-196. Zagreb: Ognjena Ptica, 1969.

- "Pojmovno-Hipoteticki Okvir Istrazivanja Odnosa Samoupravljanja i Religije." Filizofija 9 (1965): 341-356.

- Politika kao Sudbina. Belgrade: Srbija, 1982.

. "Porodica i Religija." Marksisticka Misao 3

(1985) : 28-29.

- Praksa i Religija: Problem Išcezavanja

Religioznosti. Sarajevo: Radnički Univerzitet

"Djuro Djakovie," 1960.

- "Predpostavke Razgovora i Specificnosti

Jugoslovenskog Nacionalnog i Religijskog Frostora."

In Religija i Nacija, ed. Bozo Rudez, 112-116.

Zagreb: Centar za Idejno-Teorijski Rad GK SKH, 1984.

- "Pristup Religijskom Fenomenu." Naše Teme 25

(1981): 1094-1100.

- "Problemi Metodološkog Pristupa u ProuXavanju

Religije." Sociološki pregled, January 1964, 60-75.

- "Prostor Nacionalnog i Religijskog: Nikola

Dugandzija: Religija i Nacija." Politika 24 (1983):

11-12.

. "Razgovor..." Ideje 2 (1971): 5-21.

"Refleksije o Odnosu Religije i Nacije." Kultura 65 (1984): 75-83.

- "Religija i Armija." Front 26 (1970): 8-9.

- "Religija i Crkva kao Faktor Etnicke Diferencijacije." In Religija i Nacija, ed. Božo Rudež, 26-33. Zagreb: Centar za Idejno-Teorijski Rad GK SKH, 1984.

"Religija i Crkva u Socijalizmu." In Vjerske Zajednice u Jugoslaviji, ed. Zlatko Frid, 78-103. Zagreb: Binoza, 1970 .

"Religija i Politika." Politika 78 (1981): 7-8. 
"Religija i Savremeno Društvo." Kultura 13-14 (1971): 258-316.

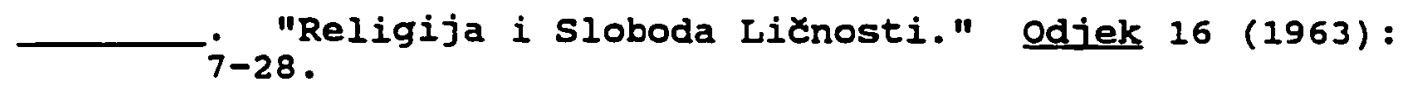

. "Religija i Socijalni Konflikti." Pregled 62 $(1972)$ : 625-634.

is "Religija i Tradicija." Gledišta 21 (1980): 315 .

"Religija kao Istina otudjenog Društva." Pregled 55 (1965): 15-32.

. "Religija kao Kulturna Cinjenica." Gledišta 12 (1971): 17-32.

. "Religija kao Psihiðka i kao Moralna Činjenica." Preqled 60 (1970): 33-44.

. "Religija kao Saznajna Cinjenica." Politika, July 1967, 9-14.

. "Religija ne IšCezava ona se Menja." Pitanja 12 $(1980)$ : 28-39. i "Religija u Samoupravljackom Drustru." Iskustva

. "Religijski Fenomen u Socijalizmu". Mladost, September 1967, 7-21.

. "Religijski Praznici." Oko 6 (1978): 1-15.

. "Religion and Church in Socialism." In Religions in Yugoslavia, ed. Zlatko Frid, 80-106. Translated by Rosemarie Hayer, Janko Paravic, Aleksandar Aranicki, Miljenko Pandakovic. Zagreb: Binoza, 1971.

- Religion and Self-Management. Paper prepared for the "First International Conference on Participation and Self-Management." Dubrovnik, 1972.

Savez Komunista i Religija. Belgrade: Komunist, 1969 .

- Socijalistiðko Društvo i Religija: Ispitivanje odnosa Izmedju Samoupravljanja i Procesa Prevladavanja Tradicionalne Religije. Sarajevo: Svjetlost, 1966 . 
- "Socijalizam Grade Svi oni koji su Kvalificirani za Promene Ekonomske i Politicke Strukture Neovisno od Toga da li su Religiozni ili Ateisti." Revija 9 (1969): 114 . 21-48.

"Socijalna Sredina i Religija." Odjek 18 (1965):

"Socijalne Predpostavke Održavanja i IšCezavanja Religije u Našem Društvu." Naše Teme 11 (1967): 1008-1032. "Sociologija Morala." Gledišta 16 (1976): 839900.

"Sociologija Religije." Teološki Pogledi 4 (1971): 85-98.

- "Structure de la conscience religieuse dans les milieux rouraux et urbains." In Conférence Internationale de sociologie Religieuse, ed. Jacques Verscheure, 169-188. Lille, France: Edition CISR, 1971.

- "Verovanje--Šansa ili Monolog: Razgovor o Religiji s Esadom Ćimićem Vodio Dragan Mojović." Gledistal 25 (1984): 83-102.

- "Višeznačnost Religijskog Fenomena i Vidovi Njegove Interpretacije." Radovi FF Sarajevo 6 $(1970-71)$ : 487-503.

- "Uticaj Samoupravljanja na Proces Prevladavanja Tradicionalne Religije: Rezultati Istrazivanja Religije." Pregled 55 (1965): 15-42.

- Uvod u Marksizam. Belgrade: Kultura, 1975.

- "Za Interdisciplinarno Prousavanje Religije i

Nacije." Pogledi 13 (1983): 79-85.

"Zašto Ljudi Dolaze do Ideje o Bogu?" Žena 43 (1985): 41-45.

Ćimić, Esad, Vuka Pavicevic, Žarko Vidovic, and Lazar Milin. "Sociologija Religije." Teološki Pogledi 4 (1971): 85-98.

Ćimić, Esad, Žarko Vidovic, Lazar Milin, Tomislav ŠagiBunić, Fuada Muhic, Žarko Gavrilovic, and Vuka Pavićević. "Religija i Savremeno Društvo." Kultura 13 (1971): 258-316. 


\section{Secondary sources}

Abramowski, Josef Edward. Filozofia Spoleczna: Wybór Pism. Warsaw: Panstwowe Wydawn, 1965.

Acton, H. B. "Dialectical Materialism." The Encyclopedia of Philosophy. 1967 ed. 2:389-397.

Adler, Max. "Marxismus ist nicht Materialismus." Neues Eorum, June-July 1967, 485-488.

Alexander, Stella. "Religion and National Identity in Yugoslavia." Occasional Papers on Religion in Eastern Europe 3 (1983): 1-19.

Alic, Sead. "Teologija i Marksizam: Uvod u Interpretacije Teza Waltera Benjamina 'o Pojmu Povijesti'." Nase Teme 27 (1983): 511-517.

Aptheker, Herbert, ed. Marxism and Christianity: A Symposium. New York, Humanities Press, 1968.

- "Marxism, Religion and Revolution." Cross Currents. Spring, 1968, 151-161. - "Marxismus und Religion." Marxistische Blätter 5 $(1967): 6-10$.

- The Urgency of Christian-Marxist Dialogue. New York: Harper and Row, 1970.

Althusser, Louis. Pour Marx. Paris: Maspero, 1966.

Aron, Raymond. "Razmišljanje o Marksizmu Marxa i Marksista." Svesci, 1984, 64-71.

Azcarate, M. "Progrès du dialogue et liberté humaine." Christianisme Social, March-April 1967, 245-258.

Baas, Emile. Introduction critique au marxisme: perspectives marxistes, perspectives chrétiennes. Paris: Colmar, Alstia, 1960.

Bahtijarevic, Štefica. Komparartivna Analiza Religijske Situacije na podrucju Zagrebacke Reqije: Desetogodišnie Razdoblje. Zagreb: Institut za Društvena Istrazivanja Sveučilista, 1985. - "Mladi i Religija: Nužnost Procjenjivanja u Širem Društvenom Kontekstu." Komunist 42 (1984): 22 . 
- Neke Društvene Dimenzije Religije i

Religioznosti." Naše Teme 22 (1978): 2343-2358.

- "Nužnost Procjenjivanja u Širem Drustvenom

Kontekstu." Komunist 42 (1984): 13-17.

- "Omladina IzmiCe Crkvi." Studentski List 32 (1977): 20-21.

- "Religijska Situacija: Od Teorijskog Pristupa Do Rezultata Istrazivanja." In Religija i Društvo, ed. Siniša zrinšCak, 71-89. Zagreb: RO Za Grafiðku Djelatnost, Samobor, 1987.

- "Religijsko Pripadanje i Sekularizacija." Naše Teme 19(1975): 480-498.

- "Religijsko Pripadanje s Aspekta Covjeka i Ijudske Zajednice." Politiðka Misao 12 (1975): 5177 .

- Religijsko Pripadanie u Uvietima Sekularizacije Društva. Zagreb: Narodno Sveutilište Grada Zagreba, 1975.

- "Savez Komunista i Religija: Pregled Rezultata Empirijskog Istraživanja." Kumrovezki Zapisi 1 (1984): 203-220.

"Seoska Omladina i Religija." Sociologija Sela 13 (1975): 139-161.

- "Sociološki i Psihološki Aspekti Religijskog Fenomena." Pitanja 8 (1976): 23-33.

- "Some Characteristics of the Religiosity of Secondary School Attendants." In Conference Internationale de Sociologie Religieuse, ed. Jacques Verscheure, 123-144. Lille: CISR, 1971.

Bahtijarevic, Štefica, and srdjan Vrcan. Manifestacija Reliqioznog Ponašanja Stanovništva Zagrebaðke Regije: Zagreb: Institut za Društvena Istrað̌ivanja Sveutilišta, 1975.

Bajsic, Vjekoslav. "Dijalog i Kategorija Kolonijalne svijesti." Kulturni Radnik 31 (1978): 36-52.

- "Kršćanin na Bespuću Zajednistva." Bogoslovska Smotra 45 (1975): 235-248. 
- Na Rubovima Civilizacije. Zagreb: Kršcanska Sadašnjost, 1972.

- "Position des chretiens envers le dialogue avec les marxistes." In Les religions en Yougoslavie, ed. Zlatko Frid, 146-153. Zagreb: Binoza, 1971.

Ball, Michael M. "Plechanov, Georgi V." Biographical Dictionary of Karxism. Edited by Robert Gorman. Westport, Connecticut: Greenwood Press, 1986:265266.

Bancroft, Nancy. "Materialism and the Christian Left: Rethinking Christian Use of Marx." Journal of Ecumenical Studies 20 (1983): 43-66.

- "Some US Christian Views of Marxism: Continuity and Change since 1975." Religious studies Review 8 $(1982): 324-330$.

Banks, R. "Christian-Marxist Dialogue: An Interim Report." The Reformed Theological Review 32 (1973): 82-93. - "Search for Man in Christian-Marxist Dialogue." Theology 77 (1974): 137-147.

Barnette, Henlee H. "Christ and Marx: The Church in Soviet Russia." Christianity Today 2 (1957): 3-5.

- Communism: Who? What? Why. Richmond, Virginia: Broadman Press, 1962 .

- "Communist and Christian Ethics." Review and Expositor: A Baptist Theological Journal 53 (1956): 364-370.

Barron, J. B., and Waddams, H. M. Communists and the Churches: Documentation. London: S.C.M., 1950.

Barth, Karl, and Hamel, Johannes. How to Serve God in a Marxist Land. New York: Association Press, 1959.

Barth, Markus. "Developing Dialogue Between Marxists and Christians." Journal of Ecumenical studies 30 (1963) : 14-29.

Barton, William E. The Moral Challenge of Communism. Some Ethical Aspects of Marxist-Leninist Society. London: Friends Home Service Committee, 1966.

Beardsley, Monroe c. "Aesthetics, History of." The Encyclopedia of Philosophy, 1967. 1:18-35. 
Beaupere, R. "L'Eglise réformée de France et le marxisme." parole et Mission 8 (1960): 64-82.

Beeson, Trevor. Discretion and Valour: Religious Conditions in Russia and Eastern Europe. Glasgow: Collings, 1974 .

. "Polish Catholic-Communist Encounter." The Christian Century 90 (1973): 1276-1277.

Belloc, A. "Dialogue avec les incroyants." Masses ouvrières. January 1964, 85-91.

Bennett, John c. Christianity and Communism Today. New York: Association Press, 1960.

Bent, Ans J. van der. "Christian-Marxist Conference in Lucern." Journal of Ecumenical Studies 23 (1986): 770 .

- "Das Thema 'Revolution' im Gespräch zwischen Christen und Marxisten." Evangel ische Kommentare, June 1968, 337-339.

- "Marxist-Christian Dialogue in Geneva." study Encounter 4 (1968): 143-147.

Bentley, James. "Christian Significance of Atheist Ernst Bloch." The Expository Times 88 (1976): 51-55.

- "Prometheus Versus Christ in the ChristianMarxist Dialogue." The Journal of Theological Studies $29(1978)$ : 483-494.

- "Three German Marxists Look at Christianity: 1900-1930." Journal of Ecumenical Studies 22 $(1980): 505-517$. - "Vitezslav Gardavski, Atheist and Martyr." Expository Times 91 (1980): 276-277.

Berger, Kurt M. "Christentum und Marxismus." Gemeinschaft und Politik 12 (1964): 294-295.

Bernstain, Eduard. Evolutionary Socialism. New York: Hartcourt Brace, 1961.

Bernstain, Richard. Praxis and Action. Philadelphia: University of Pennsylvania Press, 1971. 
Biaggini, P. "Chrétiens et communistes face au problème du mal dans I'histoire." La Nouvelle Critique, March 1965, 80-115.

Bianchi, Eugene C. "Points of Convergence in the ChristianMarxist Dialogue." Encounter 36 (1975): 37-52.

Biot, Francois. "Le dialogue suppose le rejet des intégrismes." Témoignage Chrétien, May 15, 1969.

Biser, Engen. "Dialog mit dem Unglauben." Wort und Wahrheit, May 1966.

Blanc, Edmond. "Révolution et christianisme." IDOC, October 1968, 1-6.

Blanquart, Paul. "Die Diskussion über den Humanismus bei den Französischen Kommunisten und ihre Auswirkungen auf den Dialog mit den Christen." Internationale Dialog Zeitschrift 1 (1968): 118-127.

Bloch, Ernst. Atheismus im Christentum. Zur Religion des Exodus und des Reichs. Frankfurt: Suhrkamp Verlag, 1968 .

- Auswahl aus seinen Schriften. Frankfurt am Main: Fischer Bücherei, 1967.

- Das Prinzip Hoffnung. Frankfurt am Main: Suhrkamp Verlag, 1955-1959.

- Religion im Erbe. Eingeleitet von Jürqen Moltmann. Munich: Siebenstern-Taschenbuch, 1966.

Bloesch, D. G. "Fate, Fatalism." Evangelical Dictionary of Theology. Edited by Walter A. Elwell. Grand Rapids, MI: Baker Book House, 1984. 407-408.

Bociurkin, Bohdan R., and John w. Strong. Religion and Atheism in the U.S.S.R. and Eastern Europe. Toronto: University of Toronto Press, 1975.

Bockmuehl, Claus. The Challenge of Marxism. Downers Grove, Illinois: InterVarsity Press, 1980.

- "Der Kommunismus auf der Suche nachdem Neuen Menschen." Reformatio, October 1963, 550-566.

- "Karl Marx's Negation of Christianity: A Theological Response." Evangelical Review of Theology 9 (1985): 251-263. 
. "Marxist New Man." Christianity Today 20 (1975): 53-54.

- "Real Humanism: Marxism as a Critique of Christianity." Crux 21 (1985): 3-9.

Boerner, Rolf. Der Christ und die Sozialistische Moral. Berlin: Burgscheidungen, 1960.

Bolkovac, Paul. Atheisten Christen. Atheismus im Westen. Kevelaer: Butzon und Bercker, 1966.

Bojovic, I. Review of Socjialisticko Društvo i Reliqija, by Esad ćimie. In Socijalizam 9 (1966): 1650-1652.

Bonino, Jose Miguel. Christians and Marxist: The Mutual Challenge to Revolution. Grand Rapids, Michigan: William B. Eerdmans Publising Co., 1976.

- Doing Theology in a Revolutionary World. Philadelphic: Fortress Press, 1975.

Borchert, D. M. "Marx and Christ, the Question of Violence." The Christian Century 91 (1974): 65-69.

. "Marxist-Christian Dialogue; A New Openness." Review and Expositor: A Baptist Theological Journal 68 (1971): 95-105.

Borne, Etienne. Dieu n'est pas mort: Essai sur l'atheisme Contemporain. Paris: Fayard, 1959.

Borovoy, V. "Christianisme et Révolution." Irénikon 39 $(1966)$ : $403-407$.

Borowski, Karol H. "Christians and Marxists in Poland: Dialogue or Conflict?" Occasional Papers on Religion in Eastern Europe 5 (1985): 1-13.

Bošnjak Branko. Filozofija i Kršcanstvo: Racionalna Kritika Iracionalnog Shvacanja. Zagreb: Stvarnost, 1987.

. "Hope as Problem and Ideal-Legends and Reality." Concurrence 1 (1969): 13-22.

- "Interpretation des Marxismus in Hollandischen Katechismus." Praxis 7 (1970): 361-368.

. "Kritika Religije." In Reliqija i Društvo, ed. Vjekoslav Mikecin, 7-35. Zagreb: "Ognjena Ptica," 1969. 
331

- "KršĆanstvo i Marksizam Danas." Praxis 2 (1965): 46-51.

- "Marksistiðki Pristup Religiji." Naše Teme 11 (1967): 957- 979 .

. "Moze li Religija Odumrijeti." Studentski List 20 (1965): 12-15.

- Razvoj Ideje Ateizma i Humanizma u Filozofiji: Kratak Povijesni Preqled. Zagreb: Institut za Društvena Istrazivanja SveuXilišta, 1976.

- "Religija kao Privatna stvar i Problem Dijaloga." Praxis 5 (1968): 372-387.

"Socijalizam i Religija." Praxis 1 (1964): 249257.

- "The Withering Away of Religion in Socialism." In Praxis: Yugoslav Essays in the Philosophy and Methodology of the Sosial sciences. ed. Mihailo Markovic and Gajo Petrovic, 209-215.

Dordrecht, Boston, London: D. Reidel Publishing Company, 1979.

Bošnjak, Branko, and Mijo skvorc. Marksist i Kršcanin: Dijalog prof. 0 . Mije Škvorca o Nekim Temama Knjige "Filozofija i Kršćanstvo. Zabreb: Praxis, 1969.

Bošnjak, Branko, and Rudi Supek, eds. Humanizam i Socijalizam. Zagreb: Naprijed, 1963.

Bošnjak, Branko and Štefica Bahtijarević. Porodica u Transformaciji: Crkva i Religija. Zagreb: Institut za Društvena Istrazivanja sveucilista u Zagrebu, 1970.

Bourbeck, Christine. Komm Unismus, Frage an die Christen. Der Angefochtene Mensch des Technischen zeitalters in Ost und West. Nürnberg: Laetare-Verlag, 1957.

Bourdeaux, Michael. "Dialogue with Marxists." Frontier 8 (1965): 181-184.

- "Opening Dialogue." Frontier 9 (1966): 203-205.

- Opium of the People: The Christian Religion in the USSR. London: Faber and Faber, 1965.

Brajcić, Rudolf. "Lice Kontemplacije u Konvivenciji s Marksizmom." Obnovljeni そ̌ivot 32 (1977): 193-200. 
Breton, Stanislav. "Kršcanstvo, Mistika, Marksizem." Znamenje 10 (1980): 153-161.

Brigham, F. H. "History, Philosophy of." Encyclopedic Dictionary of Religion. Edited by Paul Kevin rieagher, Thomas C. O'Brian, and Consuelo Maria Aherne. Washington, D.C.: Corpus Publications, 1979. F-N: 1676 .

Bright, L. "Kumanist and Christian in Action [With reply by K. Ward]." Theology 75 (1972): 525-535.

Brown, Harold. Christianity and the class struggle (Grand Rapids: Zondervan Books, 1971.

Bruce, F. F. "Eschatology." Evangelical Dictionary of Theology. Edited by Walter A. Elwell. Grand Rapids: Baker Book House, 1984. 362-365.

Brzozowski, Stanislaw. Idea. Lemberg, Poland: B. Poloniecki, 1910.

Burgelin, Pierre. "Christianisme et marxisme (52ème synode de l'Eglise Réformée de France)." Lettre, July $1959,8-18$.

- "Rencontre du chrétien avec le marxisme." Christianisme Social, October-November 1959, 554562 .

Butler, Richard. "The Difficult Dialogue with NonBelievers." Catholic World 205 (1967): 95-100.

Butler, J. F., and Chandran Devanesen. Communism and Christianity. Madras: Diocesan Press, 1980.

Byford, E. C. "Christians and Marxists." St Mark's Review 113 (1983): 1-21.

Calvez, J. Y. "Chrétiens et communistes devant le pluralisme social." Revue de l'Action Populaire 192 (1965): 1028-1038.

Cardonnel, J. "L'Eglise du Christ et le choix socialiste." Frères du Monde, February 1968, 5-14.

Carpenter, J.A. "On the Marxist-Christian Dialogue." Anglican Theological Review 53 (1971): 158-167.

Carre, A. M. "Le Christ au yeux de l'incroyant." Vie Spirituelle, April 1964, 418-425. 
Casalis, G. and R. Garaudy. "Printemps à Marianske Lazne." Christianisme Social, March-April 1967, 197-209.

Cazaux, P. "Dialogue entre militants ouvriers, chrétiens et marxistes." Masses Ouvrières, February 1968, 50-62.

Cecic, Vinko. "Lenjin o Religiji, Crkvi i svecenstvu." Republika 12 (1956): 1-3. . "Marx $i$ Engels o Religiji." Vjesnik 17 (1956): 9-12.

Cepeda, R. "Christian Response to a Revolutionary Situation." Reformed and Presbyterian World 28 (1965): 299-305.

Chambre, Henri. Christianity and Communism. New York: Hawthorn Books, 1960.

Chapman, Clarke G. "Jüregen Moltmann and the Christian Dialogue with Marxism." Journal of Ecumenical Studies 18 (1981): 435-450.

Chatelet, François. "La question de l'athéisme de Marx." Les Etudes Philosophiques, July-September 1966, 371384 .

Chen, D. S. C. "Communism and the Theologians." South East Asia Journal of Theology 2 (1961): 39-43.

"Chretiens et marxistes parlent de Dieu." Témoiquage Chrétien, March 1965, 9-16.

"Chretiens, rationalistes, marxistes pouvons nous changer le monde ensemble?" La Nouvelle Critique, May 1965, 153 .

"Christen und Marxisten im Gespräch." Herder-Korrespondenz $20(1966): 277-282$.

Christentum und Marxismus heute: Gespräche der paulusGesellschaft. Herausgegeben von Erich Kellner.

Vienna: Europa Verlag, 1966.

Christianisme et révolution: Colleque des 23 et 24 mars, 1968. Paris: Lettre, 1968.

"Churchmen Look at Communism." Christianity Today 11 (1967): 12-17. 
Clarkson, Kathleen L., and David J. Hawkin. "Marx on Religion: The Influence of Bruno Bauer and Ludwig Feuerbach on His Thought and Its Implications for the Christian-Marxist Dialogue." Scottish Journal of Theology 31 (1978): 533-555.

Cobb, John B., Jr. "God: God in Postbiblical Christianity." The Encyclopedia of Religion. 1987 ed. 6:17-26.

Cogniot, Georges. La religion et la science. Paris: Ed. Sociales, 1961.

Comstock, Richard. "Marxist Critique of Religion: A Persisting Ambiguity." Journal of the American Academy of Religion 44 (1976): 327-342.

Conyers, A. J. "God and Man in the Dialogue with Marxism." Christianity Today 15 (1971): 6-8.

Cottier, Georges M. L'Athéisme du jeune Marx: Ses origines Hégéliennes. Paris: Vrin, 1959.

Cox, Harvey. "New Phase in the Marxist-Christian Encounter." Christianity and Crisis 25 (1965): 226-230.

- On Not Leaving It to the Snake. New York: Macmillan and Co., 1967.

Crespy, Georges. "Marxisme et théologie." Etudes Theologiques et Reliqieuses, no. 68 (January 1959), 10-30.

Crespy, Georges, and Guy Wagner. Christianisme et marxisme: les communistes et les chrétiens. Montpellier: Société d'Evangélisation du Bas-Languedos, n.d.

Crocker, David A. Praxis and Democratic Socialism. The Critical social Theory of Markovic and stojanovic. Atlantic Highlands, New Jersey: Humanities Press and Harvester Press, 1983.

Cronin, J. "Encyclical Anti-Marxist but widens Opening to Left; Basic Differences Between Communist Doctrine and Pacem in Terris." Catholic Messenger 81 $(1963): 65-78$.

Cvitkovie, Ivar. Bilješke o Religiji. Sarajevo: Oslobodenje, 1980.

"Engelsova Socijalna Kritika Religije." Iskustva 3 (1973): 5-8. 
. "Lenjin o Religiji i Crkvi." Odjek 23 (1970): 23-26.

- Marksisticka Misao i Religija: Kritika Teološke Kritike Odnosa Marksizma i socijalizma Prema Religiji i Religijskim Zajednicama. Sarajevo: Svjetlost, 1980 .

. "Religija i Industrijalizirano Društvo." Odjek 24 $(1971): 8$.

- Religija: Fitania i Odgovori. Sarajevo: Centar Društvenih Aktivnosti RK SSOBiH, 1983.

- "Religioznost Mladih kao Izraz Njihovih Neriješenih Konfliktnih Situacija." Spektar 1 (1969): 23-34. "Teze O Dijalogu." Crkva u svijetu 15 (1980):
164-165. . "Uticaj Porodice na (A) Religioznost Djeteta." porodica i Djete 20 (1972): 11-12.

Cvrlje, vjekoslav. "Katoliðka Crkva i Suvremeni svijet: Dijalog Crkve sa Svijetom." Pregled 71 (1981): 1288-1302.

Curic, Josip. "Još Jedna Marksistička Analiza Religije." Crkva u Svijetu 18 (1983): 193-204.

Cancar, Nusret. "Vjera Izmedju svjetovnog i Duhovnog-Duhovni, Psihološki i Kulturni Aspekti Religijskog Fenomena." Islamska Misao 11 (1989): 14-21.

"Danger of Christian-Marxist Dialogue [editorial]." Christianity Today 12 (1967): 26-27.

Davis, Forest K. "Communism as Religion." Crozer Quarterly 28 (1951): 217-226.

de Vries, P. H. "Hegel, Georg Wilhelm Friedrich." Evangelical Dictionary of Theology. Edited by Walter A. Elwell. Grand Rapids: Baker Book House, 1984. 502-503.

Dean, Thomas. Post-Theistic Thinking: The Marxist-Christian Dialogue in Radical Perspective. Philadelphia: Temple University Press, 1975. 
Decke, G. "Die theoretische Basis von Marcuses Geschichtsphilosophie und Gesellschaftstheorie; Freuds psychoanalytische Anthropologie als Marxismus-Ersatz? Zeitschrift für Evangelische Ethik 12 (1968): 372-377.

Dedier, vladimir. Izqublieni Boj J. V. Staljina. Ljubljana: Delo, 1969 .

Dekoster, Lester. Communism and Christian Faith. Grand Rapids, Michigan: Willam B. Eerdmans Company, 1956.

Delbrel, M. "Ville marxiste et présence de l'eglise." Parole et Mission, October 1958, 367-383.

Delooz, Pirre. "The Dialogue Between Christians and NonBelievers." Pro Mundi Vita 111 (1987): 1-38.

Delvin, Kevin. "The Catholic-Communist Dialogue." Problems of Communism, May-June 1966, 31-38.

"Democratie nouvelle. Débat avec G. Casalis, A. Dumas, R. P. Chenu, R. P. Gardey, R. Garaudy, et J. Gacon." Revue Mensuelle de Politique Mondiale, April 1966, 72-90.

A Dictionary of Philosophy. Edited by Antony Flew. London: Pan Books, 1979. S. v. "Contradiction."

Desroche, Henri. "Communisme et religion: Sur une postéritré communisante de la religion mennaisienne." Europe, February-March 1954, 116192 .

- Marxisme et religions. Paris: Presses Universitaires de France, 1962.

- "Socialisme et sociologie du christianisme." Cahiers Internationaux de Sociologie 21 (1956) : 156158 .

- Socialismes et sociologie religieuse: Textes de Friedrich Engels traduits et présentés avec le concours de G. Dunstheimer et M. L. Letendre. Paris: Cujas, 1965. 
Diskussion zur "Theologie der Revolution." Mit Beiträgen von H. Assman. A. Bezerra de Melo, H. Camara, $W_{\text {. }}$ Dirks, E. Feil, H. Gollwitzer, P. Lehmann, M. Lotz, J. Moltmann, A. Rich, D. A. Seeber, R. Shaull, R, F. Smith, R. Strunk und R. Weth. Herausgegeben von Ernst Feil und Rudolf Wetn. Munich: Chr. Raiser Verlag, 1969.

Disputation zwischen Christen und Marxisten. Herausgegeben von M. Stöhr. Munich: Chr. Kaiser Verlag, 1966.

Djilas, Milovan. The New Class. New York: Praeger, 1957.

Dugandzija, Nikola. "Bilješke o Religiji." Naše Teme 22 $(1978): 325-326$.

- "Religija i Potrošacko Društvo." Naše Teme 22 (1978): 1312-1318.

- Religija kao Dio Coviekovog svijeta. Zagreb: Fakultet Politixkih Nauka: Postdiplomski studij iz Teorije Ateizma i Religije, 1972 .

. "Socijalizam, Sociologija, svetost." Revija za Sociologiju 9 (1979): 41-47.

Dumas, André. "Christian Meets Marxist." Frontier 8 (1965): 16-17.

- "Theologisches Gespräch zwischen Christen und Atheisten." Junge Kirche 25 (1964): 623-625.

Dupre, Louis. "The Challenge of Marxism." Cross Currents 12 (1962): 327-335.

Eagleson, John, ed. Christians and Socialism. Maryknoll, New York: Orbis Books, 1975.

Ehlen, Peter. Der Atheismus im dialektischen Materialismus. Munich: Pustet, 1961.

Ellis, Jane. "New Soviet Thinking on Religion." Religion in communist Lands 17 (1989): 100-111.

Engels, Frederick. Anti-Düring. New York: International Publishers, 1966. - Dialectics of Nature. New York: International Publishers, 1940 . 
- "Engels to Margaret Harkness." In Karl Marx and Frederick Engels: Selected Correspondence, 478-480. Moscow: Foreign Languages Publishing House, 1955.

- "Engels to $W$. Borgius in Breslau." In Karl Marx and Frederick Engels: Selected Works, 704-706. New York: International Publishers, 1968.

- Feuerbach and the End of Classical German

Philosophy. In Karl Marx and Frederick Engels:

Selected Works, 594-632. New York: International

Publishers, 1968.

- "Introduction to Dialectics of Nature." In $\operatorname{Kar} 1$ Marx and Frederick Engels: Selected Works, 342-357. New York: International Publishers, 1968.

- Socialism: Utopian and Scientific. Westport, Connecticut: Greenwood Press, Publishers, 1977.

Erickson, Nancy. "Theory and Practice in Contemporary Marxism." Fides et Historia 16 (1984): 38-54.

Evans, J. C. "Beyond Dogmatism in Europe's MarxistChristian Dialogue." The Christian Century 91 $(1974)$ : 69-74.

Fabro, C. "The Positive Character of Modern Atheism." Concurrence 1 (1969): 66-76.

Falk, Heinrich, Hg. Kirche und Kommunismus: Der

Dialektische Materialismus und seine Verurteilung.

Dủsseldorf: Patmos, 1956.

Farner, Konrad. "A Criticism of Christianity." Communio Viatorum 9 (1966): 25-50.

- "Dank eines Marxisten an Karl Barth: Zum achtzigsten Geburtstag 10. Mai 1966." Vorwärts, May $26,1966,4$.

. "Dialog aus Marxistischer Sicht." Junge Kirche 28 (1967): 697-707.

Faupel, Charles E. "Marxism and Christiarity: Their Images of Man." Journal of the American Scientific Affiliation 33 (1980): 135-139.

Fedoseev, P. N. "K Dialogu med Krscani in Marksisti na XVI Svetovnem Filozofskem Kongresu." Anthropos, nos. 12 (1979): 244-248. 
Feinberg, John S. "Theism." Evangelical Dictionary of Theology. Edited by walter A. Elwell. Grand Rapids: Baker Book House, 1984. 1080-1082.

Ferkiss, V. "A New Approach to Communism?" Social Order 13 (1963): 38-47.

Ferre, N. F. S. "Church, Communism or Christ-Community." Journal of Religious Thought 22 (1965/66): 51-71.

Fessard, Geston. "The Theological Structure of Marxist Atheism." Concilium 16 (1966): 7-24.

Fetscher, Iring. "Developments in the Marxist Critique of Religion." Concilium 16 (1966): 131-154.

- Die Freiheit im Lichte des Marxismus-Leninismus. Bonn: Bundeszentrale für Heimatdienst, 1960.

. "Wandlungen der Marxistischen Religionskritik." Concilium 2 (1966): 455-466.

Fiamengo, Ante. "Depolitizacija Crkve i Privatizacija Religije." Politicka Misao 4 (1967): 166-182.

- "Drustveno-Ekonomski Uvjeti Postanka Krscanstva." Kulturni Radnik 5 (1982): 208-211.

- Kako ie Postala Religija. Belgrade: Narodna Knjiga, 1952 .

- Idejni Problemi u oblasti Reliaije. Belgrade: Visoka Škola Političkih Nauka, 1962. Marksisticko Shvatanje Religije. Belgrade: Rad, 1958 .

- "Neki Elementi Krščanstva koji Poticu iz Drugih Religija." Kulturni Radnik 5 (1952): 340-344.

- Porijeklo i Društvena Uloga Religije. Zagreb: Novo Pokoljenje, 1950.

- "Primitivni Oblici Religije." Kulturni Radnik 4 (1951): 593-597.

Filipovic, Muhamed. "Marksisticki Pristup Fenomenu Religije." Karksizam i Nastava, no. 13 (1977): 2128 . 
Fink, willi. "Marxisten und Christen Arbeiten Gemeinsam." Die Gegen-wart. Zeitschrift für BIindenfragen 20 (1966): $1-3$.

Fleischmann, Ivo. "Teige, Karel." Biographical Dictionary of Neo-Marxism. Edited by Robert Gorman. Westport: Greenwood Press, 1985. 408-409.

Foulquier, Emile. Communisme et Responsabilités des Chrétiens. Paris: Ed. Ouvrières, 1951.

"Die Frage der Koexistenz von Religion und Atheismus vor dem Exekutiv-ausschuss in Odessa." Herder-Korrespondenz 18 (1964): 336-337.

Franic, Frane. Putovi Dijaloga. Split: Crkva u svijetu, 1973.

Freedom of Religion in the Federative People's Republic of Yugoslavia. Belgrade: Jugoslovenska knjiga, 1948 .

Frid, zlatko. "Još o Aktuálnim Pitanjima Odnosa s Katoliðkom Crkvom." Naše Teme 12 (1968): 975-990.

Froković, Mirko. "Marksizam i Religija." Vojnopolitiðki Glasnik 5 (1952): 98-113.

Fromm, E. Marx's Concept of Man. New York: Frederick Ungar, 1961 .

Frostin, Per. "The Marxist Criticism of Religion." Africa Theological Journal 2 (1979): 56-64.

Fuchs, Emil. "Christen und Marxistische Weltgestaltung." Communio Viatorum: A Theological Quarterly 2 (1959): 173-186.

- Christliche und Marzistische Ethik. Hamburg: Herbert Reich, Evang. Verlag, 1957-1959. Marxismus und Christentum. Leipzig: Koehler, 1953.

Fulton, Robert B. Original Marxism Estranged offspring. A study of points of contact and conflict Between original Marxism and Christianity. Boston: Christopher Publishing House, 1960.

Gaillard, A. Marxisme et christianisme. Paris: Soc. centr. d'Evangélisation, 1958 . 
Gaitskell, Hugh. The Challenge of Co-Existence. Cambridge, Massachusetts: Harvard University Press, 1957.

Garadzha, V. I. "Atheist Work: A Re-evaluation." Reliaion in Communist Lands 18 (1990): 72-79.

Garaudy, Roger. "Christian-Marxist Dialogue." Journal of Ecumenical Studies 4 (1967): 207-222.

- "Communists and Christians in Dialogue." Union Seminary ouarterly Review 22 (1967): 205-212.

- De l'anathème au dialogue: Un marxiste tire les conclusions du concile. Paris: Plon, 1966.

- Dieu est mort: etude sur Hegel. Paris: Presses Uni-versitaires de France, 1962.

- L'Eglise, le communisme et les chrétiens. Paris: Ed. Sociales, 1949 .

- From Anathema to Dialoque. New York: Radom House, 1968.

- Humanisme marxiste. Paris: Ed. Sociales, 1957.

- Karl Marx. Paris: Seghers, 1964.

- Le Marxisme et la personne humaine: Suivi de réponses à quelques questions. Bruxelles: Cercle d'Education Populaire, 1961.

- Perspectives de l'homme: Existentialisme: Pensée Catholique. Marxisme, 1929-1959. Paris: Presses Universitaires de France, 1959.

- Peut-on etre communiste aujourd'hui? Paris: Ed. Grasset, 1968 .

Garaudy, Roger, and Lauer, Quentin. A Christian Communist Dialogue. Garden City, New York: Doubleday and Co., 1968 .

Gardavsky, V. "Dialog in Amerika." Internationale Dialog Zeitschrift 2 (1969): 187-188.

- God Is Not Quite Dead. Baltimore: Penguin Books, 1973 .

. "Ways of Encounter." Concurrence 1 (1969): 55- 
Gardner, James Earl. "An Examination of Selected Aspects of Marxist and Christian Musical Aesthetics." Ph.D. dissertation, Southwestern Baptist Theological Seminary, 1982 .

Geisler, N. L. "Freedom, Free Will, and Determinism." Evangelical Dictionary of Theology. Edited by Walter A. Elwell. Grand Rapids: Baker Book House, 1984. 428-430.

"Genesis." SDA Bible Commentary. Edited by F. D. Nichol Washington, D.C.: Review and Herald Pub. Assn., 1953-1957. 1:216.

Gibson, Arthur. The Faith of the Atheist. New York: Harper, 1968 .

Gill, D. W. "Secularism, Secular Humanism." Evangelical Dictionary of Theology. Edited by Walter Elwell. Grand Rapids, Michigan: Baker Book House. 996-997.

Gill, Jerry. "Reason." The Westminster Dictionary of Theology. Edited by Alan Richardson and John Bowden. Philadelphia: Wesminster Press, 1983. 486.

Girardi, Giulio. "Der Atheismus und das Moralproblem." Internationale Dialog Zeitschrift 1 (1968): 407-411.

- Marxism and Christianity. Translated by Kevin

Traynor. New York: Macmillan Company, 1968. - "Through Revolution to Peace." Dialogue 1 (1968): 47-54.

Godin, H., and C. Bordet. "Dialogue avec les incroyants." Masses Ouvrières 225 (1966): 53-64.

Gollwitzer, Helmut. Athéisme Marxiste et foi chrétienne. Tournai: Casterman, 1965.

- The Christian Faith and the Marxist Criticism of Religion. New York: Charles Scribner's Sons, 1970. - "L'Eglise chrétienne et l'athéisme communiste." Le Semeur, January 1962, 369-377. - Die Marxistische Religionskritik und der Christliche Glaube. Munich: SiebensternTaschenbuch, 1965.

Gonzales-Ruiz, Jose Maria. The New Creation: Marxist and Christian. Maryknoll, New York: Orbis Books, 1976. 
Gorman, Robert A. "Introduction: The Mosaic of Marxism." Biographical Dictionary of Neo-Marxism. Edited by Robert A. Gorman. Westport, Connecticut: Greenwood Press, 1985. 3-24.

- "Introduction." Biographical Dictionary of Marxism. Edited by Robert A. Gorman. Westport, Connecticut: Greenwood Press, 1986. 3-11.

- Neo-marxism: The Meaning of Modern Radicalism. Westport, Connecticut: Greenwood Press, 1982 .

Gozzini, M. Il Dialogo Alla Provo. Firenze: Vallecchi, 1964 .

Gourmelen, M., and Barrau, P. "Communistes et chrétiens." Masses Ouvrieres, February 1967, 34-63.

GraCanin, Duro. Vierodostojnost Nadnaravno Objavliene Reliqije. Zagreb: Nadbiskupsko Bogoslovsko Sjemenište, 1961.

Grebing, Helga. Der Revisionismus. Von Bernstein bis zum Prager Fruhling. Munich: Verlag C. H. Beck, 1977.

Grebo, zdravko. "Bilješka o 'Religioznom Karakteru Marksizma'." Lica 7 (1977): 35-43.

Grlic, Danko. "O Ateizmu i zbiljskoj Kritici Religije." Filozofija 3 (1959): 65-70.

Grmić, Vekoslav. "Ateistið̌na Duhovnost." Znamenje 4 (1974:301-308.

- "Teologija Dialoga Cerkve s svetom." Bogoslovni viesnik 25 (1965): 195-230.

Gruenwald, Oskar. "Humanism and Marxism: The Yugoslav Perspective." Ph. D. dissertation, claremont Graduate School, 1971.

- "Praxis." Beographical Dictionary of NeoMarxism. Edited by Robert A. Gorman. Westport, Connecticut: Greenwood Press, 1985. 349-353.

Guerry, Emile. Eqlise catholique et communisme athé: Pourquoi l'eqlise oppose-t-elle un refus formel à la doctrine anti-religieuse du communisme sovietique? Paris: Bonne Presse, 1960.

Gutierrez, Gustavo. A Theology of Liberation. New York: Orbis Books, 1973 . 
Habgood, John. "Science and Religion." The Westminster Dictionary of Theology. Edited by Alan Richardson and John Bowden. Philadelphia: Wesminster Press, 1983. 526-528.

Hamel, Johannes. Christenheit unter Marxistischer Herrschaft. Berlin: Käthe Vogt Verlag, 1959.

Harder, Güther. "Jüdische und Christliche Antwort auf dem Atheismus. Studientagung 'Kirche und Judentum' von 2.-6. März 1964 in Hannaover." Junge Kirche 25 (1964): 320-328.

Havemann, Robert. "Christentum und Marxismus Heute." Neues Forum, 1966, 163 .

Hebblethwaite, Peter. "Atheists at the Council." The Month $35(1966)$ : 138-146.

"Dialog in England." Internationale Dialog

Zeitschrift 1 (1968): 99-100.

. "Gespräch mit Marxisten." stimmen der Zeit, July $1967,48-54$.

- "Last Week at Marienbad. Marxist-Christian Dialogue in Czechoslovakia." The Tablet 221 (1967): 493-495.

. "More Talking with Marxists." The Month 37 $(1967)$ : $342-349$.

Heimann, Eduard. Reason and Faith in Modern Society: Liberalism, Marxism and Democracy. Middletown, Connecticut: Wesleyan University Press, 1961.

Heller, Agnes. "Marxistiche Ethik, Christliche und Gesellschaftliche Revolution." International Dialog Zeitschrift 5 [1972]:70-78).

Hellwig, Monika. "Actual and Possible Convergence in Christian and Marxist Projections of Human Fulfillment." Philosophy and Theology 1 (1986): 121-156.

Henry, A. M. "L'Athéisme est une foi." Parole et Mission, october 1961, 525-535.

Henry, Carl F. H. "Christian-Marxist Dialogue." Christianity Today 27 (1977): 28-29. 
Hinz, E. "Toward a New Interpretation of Religion and Atheism in the Secular Society." Lutheran World 13 $(1966): 377-382$.

Hoffmann, G., and W. Wille, eds. World Mission and World Communism. Edinburgh: The Saint Andrew Press, 1970.

Hoffmann, Stephen P. "Christian-Marxist Dialogue in a Communist state: 'Critical solidarity' in the German Democratic Republic." Fides et Historia 16 $(1984): 6-17$.

Hollenweger, . J. "Marxistische und Kimbanguistische Mission; ein Vergleich." Evangelische Theologie 34 $(1974)$ : 434-447.

Hollitscher, $W$. "The Logic of Atheism." Concurrence 1 (1969): 77-81.

Hollitscher, Walter. "Marxistische Religionssoziologie." Internationale Dialog Zeitschrift 1 (1968): 89-94.

. "Religion und Revolution. Bericht uber eine Dialog- Tagung." Internationale Dialog Zeitschrift 2 (1969): 91-94.

Hoover, A. J. "God, Arguments for the Existence of." Evangelical Dictionary of Theology. Edited by Walter A. Elwell. Grand Rapids: Baker Book House, 1984. 447-451.

Hoover, J. E. "Christianity Encounters Communism." Christianity Today 7 (1962): 3-5.

Hommes, Jakob. Kommunistische Ideologie und Christliche Philosophie. Bonn: Bundeszentrale für Heimatdienst, 1957.

- Krise der Freiheit: Hegel, Marx, Heidegger. Regensburg: F. Pustet, 1958.

L'Homme chrétien et l'homme marxiste. Contributions de $R$. P. Jolif, O.P., R. P. Dubarle, O.P., J. BosC, A. Dumas, A. Casanova, R. Garaudy, G. Mury, etc. Paris: La Palatine, 1964.

Horak, Josip. "Church, state, and Religious Freedom in Yugoslavia: An Ideological and Constitutional Study." Journal of Church and State 19 (1977): 278300 . 
Hromadka, J. L. An der Schwelle des Dialogs zwischen Christen und Marxisten. Frankfurt am Main: StimmeVerlag, 1965.

- "Au Seuil du dialogue entre chrétiens et marxistes." Lettre Mensuelle sur l'Evangélisation, March 1965, 1-11.

- Das Evangelium auf dem Wege zum Menschen. Berlin: Evangelische Verlagsanstalt, 1961.

- Evangelium fur Atheisten. Berlin: Käthe Vogt Verlag, 1958 .

"Evangile pour les athées." Le Semeur, January $1962,343-367$.

. "Gospel for Atheists." Risk 1 (1965): 16-40.

- "On the Treshold of a Dialogue." Communio

viatorum 7 (1964): 130-138.

- "Unuberwindlicher Gegensatz oder Ausraumbare Missver-standnisse?" Communio Viatorum: A

Theological Quarterly 10 (1967): 109-114.

Initiative in History: A Christian-Marxist Exchange. Cambridge, Massachusetts: The Church Society for College Work, 1967.

Janezkovie, Janez. "Izkustvena znanost, Svetovni Nazor, Svoboda Vesti." Nova Pot 4 (1952): 72-86.

- Kršcanstvo in Marksizem: od Polemike do Razgovora: Izabrani Spisi. Celje: Mohorjeva Druzba, 1976.

- "Od Znanosti do Vjere." Dobri Pastir 8 (1957): 47-62. . "Tomaz Akvinski in Karl Marx." Nova Pot 6 $(1954)$ : 250-252.

Jaroszewski, Tadeusz M. "Confrontation, Dialogue, and Cooperation." In Church within Socialism, ed. Erich Weingartner and Giovanni Barberini, 186-192. Rome: IDIOC International, 1976.

Jaures, Jean. La question religieuse et le socialisme. Paris: Ed. de Minuit, 1960. 
Jevtic, Atanasije. "Marksisticko i HrišCansko Shvatanje Religije i Filozofije." Teološki Pogledi 15 (1985): 131-144.

Joes, Anthony J. "Christian-Marxist Dialogue: A Look at Some Foundations." Worldview 20 (1977): 44-46.

Johnson, Ernest F. A Vital Encounter: Christianity and Communism. New York: Abingdon Press, 1962.

Johnson, Ross A. "The Dynamics of Communist Ideological Change in Yugoslavia: 1945-1953." Ph. D. dissertation, Columbia University, 1967.

Jovankin, Uroš. "Kakva je Naša Ljudska Reð." Glasnik Srpske Pravoslavne Crkve 62 (1981): 133-134.

Jukie, Jakov. "Fizionomija suvremenog svijeta: Automatizirani Covjek." Crkva u svijetu 5 (1970): 109-125.

"KritiCki Pristup Sociologiji Religije." Crkva u Svijetu 11 (1976): 5-20.

. "Kritika Društvenog Tumacenja Puðke Religije." Crkva u svijetu 19 (1984): 5-19.

- "Kriza Znanosti o Religiji." Crkva u Svijetu 9 $(1974)$ : 209-219.

- "Na Izvorima Modernog Mentaliteta: Mjesto Ateizma u Modernom Mentalitetu." Crkva u Svijetu 1 (1966): $11-32$.

- "Od Nereligioznosti do Ateistickog Kršćanstva." Crkva u Svijetu 14 (1979): 111-132.

- "Pluralistiðki Pristup Religiji." Crkva u Svijetu 12 (1977): 21-35.

- Reliqija u Modernom Industrijskom Društvu.

Split: Crkva u Svijetu, 1973 .

"Religija u stjecištu Razliðitih Znanstvenih

Pristupa." Crkva u Svijetu 18 (1983): 298-299.

- "La religion et les sécularismes dans les société socialistes." Social Compass: International Review of Sociology of Reliqion 28 (1981): 5-24.

- "Sociološki Pristup Sekularizaciji." Bogoslovska Smotra 45 (1975) : 39-48. 
Juras, Jure. "Za Zbiljski Dijalog." Razlog 3 (1963): 192198.

Jurašek, 2. Review of Drama Ateizacije, by Esad cimic. In Revija [Osijek] 12 (1972): 71-72.

Jurie, Dragutin. o Dijalogu Marksista i Kršcana. Magistarski Rad. Zagreb: Fakultet Politið̌kih Nauka, Centar za Društvena Istraživanja, 1980.

Kangrga, Milan, "Problem Otudjenja u Marksovu Djelu." In Humanizam i Socijalizam, ed. Branko Bošnjak and Rudi Supek, 99-108. Zagreb: Naprijed, 1963.

- "Program SKJ--Oslobadjanje Stvaralackih snaga Socijalizma." In Humanizam i Socijalizam, ed. Branko Bošnjak and Rudi Supek, 16-21. Zagreb: Naprijed, 1963.

Kant, Immanual. The critique of Pure Reason. In Great Books of the Western World, ed. Robert Maynard Hutchins, 1-248. Chicago: William Benton, 1952 .

Katalinic, Ante. "Ontologijska Podloga za Dijalog s Ateistima." Obnovlieni Żivot 27 (1972): 56-64.

Kaufmann, L. "Christentum und Marxismus." Orientierung 30 (1966) : 127-129.

Kay, H. "Loving the Communist: The Encyclical Pacem in Terris." Christian Order 4 (1963): 372-377.

Kecmanovic, Nenad. "Može li Marksizam da bude Zanimljiv." Kulturni Radnik 34 (1981): 200-205. - Review of Drama Ateizacije, by Esad Ćimic. In Gledista 16 (1975): 211-123.

Kemp, Peter. "Marx et le poème religieux: le christianisme dans le 'Capital'." Recherches de Science

Religieuse 64 (1976): $25-38$.

Kergomard, Alain. "Idéologie communiste et téologie (Une appréciation chrétienne du fait marxiste)." Foi et Vie, January-February 1956, 37-47.

Kerševan, Marko. "Atheism: Is It Essential to Marxism." Journal of Ecumenical Studies 22 (1985): 501-505. Ateisti in Religija Danes. Ljubljana: Komunist, 1968 . 
- "Dva Pristupa Religiji: Religija kao AlijenacijaReligija kao Način Covjekova Prisvajanja svijeta." Naše Teme 25 (1981): 1643-1655.

. "Humanisticna Ideologija in Religija." Problemi 11 (1973): 30-49.

- Komunisti in Religija. Ljubljana: Fakulteta za Sociologijo, Politicne Vede in Novinarstvo, 1968.

- "Kriza Sodobne Religioznosti." Idrijski Razgledi 10 (1965): 71-76.

- "Lenin in Religija." Teorija in Praksa 13 $(1976)$ : 44-45.

"MarksistiCki Pristup Fenomenu Religije." Socijalizam 20 (1977): 2183-2200.

- "Marksizem in Religija." Naši Razaledi 27 (1978): 129-131.

- "Marksizem in Vprasanja Religije." Komunist 31 $(1973):$ 4-5.

"Marxist Approach to Religion." Socialist Thought and Practice 23 (1983): 85-103.

- "Neka Sporna Pitanja Marksisticke Teorije Religije." Naše Teme 6 (1967): 980-993.

- "Odnos Komunista Prema Religiji." Naše Teme 19 (1975): 893-894.

- "Odnos Marksa i Engelsa prema Religiji." Lica 6 $(1976)$ : 58-69.

- "Oktober, Lenjin in Religija." Teorija in Praksa 14 (1977): 1481-1483.

- "Problemi Religije u Savremenom Drustur." Sociologija 17 (1975): 453-466.

. "Religija kao Individualna i Društvena Pojava." Pogledi 4 (1974): 85-99.

- "Religion and the Marxist Concept of Social Formation." Social Compass: International Review of Sociology of Relition 22 (1975): 3-4, 323-342.

"Savremeno Hrišćanstvo i Ideologija." Kultura 13-14 (1971): 78-79. 
- "Teoretski Model za Proucavanje Religije kao Specifične Prakse." Naše Teme 5 (1969): 732-757.

Kidd, Benjamin. "Sociology." The Encyclopaedia Britannica, 1926. 25-26:322-331.

Kininger, Ewald. Koexistenz-Proexistenz, Ueber die OstWest Annäherung. Vienna: Europa Verlag, 1968.

Kirk, Andrew. "Critique: Marx and the Bible." Sejourners 6 $(1977): 35-37$.

- "The Meaning of Man in the Debate between Christianity and Marxism." Themelios 1 (1976): 8593.

Klaus, Georg. Jesuiten, Gott, Materie. Des Jesuitenpaters Wetterrevolte wider Vernunft und wissenschaft. Berlin: VEB, Deutscher. Verlag der Wisschenschaften, 1958 .

Klohr, olof, Hg. Religion und Atheismus Heute. Ergebnisse auf Auf- gaben Marxistischer Religionssoziologie. Berlin: Deutscher Verlag der Wissenschaften VEB, 1966.

Klugmann, James, ed. Dialogue of Christianity and Marxism. London: Lawrence and Wishart, 1968.

Klugmann, J., and Oestreicher, Paul, eds. What Kind of Revolution: A Christian-Communist Dialogue. London: Panther Books, 1968 .

Knudsen, R. D. "Anathema or Dialogue?" The Westminster Theological Journal 34 (1972): 137-151.

Koch, Hans-Gerhard. The Abolition of God: Materialistic Atheism and Christian Religion. London: S.C.M., 1963 .

- Luther's Reformation in Kommunistischer sicht. Stuttgart: Quell-Verlag, 1967.

- Neue Erde Ohne Himmel. Der Kampf des Atheismus gegen das Christentum in der DDR--Modell einer weltweiten Auseinandersetzung. stuttgart: QuellVerlag, 1963.

Koenig, Franz, Cardinal. "Athéisme et foi chrétienne après le concile: conférence prononcée à Paris." Documentation Catholique, March 1969, 279-286. 
- "Dialog als Abenteuer." Neues Forum, AugustSeptember $1968,529-533$. "Sur le secretariat pour les non-croyants."
Information Catholiques Internationales 240 (1965):
25-26.

Kolakowski, L. Marxism and Beyond: on Historical Understanding and Individual Responsibility. London: Pall Mall, 1969.

- Main Currents of Marxism. Vol. 3. Oxford: oxford University Press, 1978. - Toward a Marxist Humanism: Essays on the Left Today. New York: Grove Press, 1968.

Konig, Franz. "The Second Vatican Council and the Secretariat for Non-Believers." Concurrence 1 (1969): 34-42.

Korac, Veljko. "In Search of Human Society." In Socialist Humanism, ed. Eric Fromm, 1-15. New York: Anchor Books, 1966.

Kowalczyk, stanislaw. "The Possibility of Christian-Marxist Dialogue on Human Rights." Soundings: An Interdisciplinary Journal 67 (1984): 165-171.

Kraeter, Dieter. "Christen und Marxisten im Gespräch." Kirche in der leit 20 (1965): 474-476.

Krasnotsvetov, Pavel. "International symposium: Christians and Marxists--Dialogue on Peace." Journal of Moscow Patriarchate 3 (1984): 42-43.

Krejci, Jaroslav. "'Dialogue' and 'Coexistence': A TestCase from Czechoslovakia." Occasional Papers on Religion in Eastern Europe 3 (1983): 10-14. - "Dialog des Marxismus mit dem Christentum als Friedensbeitrag." Internationale Dialog Zeitschrift 1 (1968): 43-49.

Krešic, Andrija. Filozofija Religije. Zagreb: Naprijed, 1981

. "Nenasilje kao Ljudski NaCin Opstanka." Praxis 7 $(1970): 53-63$. 
- "The Proletariat and Socialism in the Works of Marx and in the World Today." Praxis International 3-4 (1969): 373-396.

Kribl, Josip. Religija Iskustva i MarksistiCkog Mišlienia. Zagreb: Josip Kribl, 1978 .

Kristo, Jure. "Relations Between the state and the Roman Catholic Church in Croatia, Yugoslavia in the 1970 s and 1980s." occasional Papers on Religion in Eastern Europe 3 (1982): 22-33.

Kuðinar, zdravko. "Marksizam i Kritið̌ki Pojam Religije." Kultura 13-14 (1971): 43-52.

Kuczynski, Janusz. "The Sense of Existence: Creativity and Community." Dialectics and Humanism 5 [1978]:190173).

Kuhn, Harold B. "A Christian-Marxist Dialogue--of Sorts: Most Soviet-Bloc Contries' Dialogue Must Be Conducted with Caution." Christianity Today 26 (1982) : 42-43.

Kukoð, Mislav. "Drama Religijske i Ateističke Svesti." Gledišta 24 (1985): 137-163.

- Review of Drama Ateizacije, by Esad ćimic. In Naše Teme 30 (1985): 605-607.

- Review of Politika kao Sudbina, by Esad ćimie, In Sociološki Preqled 28 (1984): 110-112.

Küng, Hans. Does God Exist?. Garden City, New York: Doubleday and Company, 1980.

Künzli, Arnold. "Marxists on the Beach." Dialoque 1 (1968): 79 .

Kupisch, Karl. Das Jahrhundert des Sozialismus und die Kirche. Berlin: K. Vogt, 1958 .

Kurien, Mathew K. "The Marxist Concept of Man." Indian Journal of Theology 22 (1978): 112-122.

Kusin, Vladimir V. "Prague Spring." Biographical Dictionary of Neo-Marxism. Edited by Robert $A$. Gorman. Westport, Connecticut: Greenwood Press, 1985. 347-348.

Lacroix, Jean. Le sens de l'athéisme moderne. Paris: Casterman, 1958 . 
Ladriere, J. "La critique de la religion chez Marx." Réponse, October 1965-January 1966, 4-9.

Lafay, H. "Marxisme, christianisme, laicité." Lettre 79 $(1965): 10-16$.

Lalic, Ivan. "O Marksizmu i Religiji." Naše Teme 25 (1991): 1141- 1142.

Lamon, Charles M. The Challenge of the Protestant Faith to Communism. Nashville: Tidings, 1962 .

Lauer, J. "Marxism: Philosophy of Freedom." Thought 38 $(1963): 22-38$.

Lauer, Quentin. "Response Occasioned by McGovern's 'Atheism: Is It Essential to Marxism'?" Journal of Ecumenical Studies 22 (1985): 524-528.

"Le christianisme vu par des marxistes." Informations Catholiques Internationales, June 1958, 23-24.

Le Blond, J. M. "Le chrétien devant l'athéisme actuel." Etudes, June 1954, 289-304.

Lebar, Joze. "Engelsovo Vrednotenje Prakrscanstva." Znamenje 3 (1973): 239-247.

Lee, Francis Nigel. Communist Eschatology. Nutley, New Jersey: The Craig Press, 1974.

Leeuwen, Arend Th. van. "The Christian-Marxist Dialogue." Catolic World 208 (1969): 219-222.

Lefebvre, Henri. Problèmes Actuels du Marxisme. Paris: Presses Universitaires de France, 1963.

Lehmann, K. "Zum Gespräch zwischen Christentum und Marxismus." stimmen der Zeit 91 (1966): 468-474.

Lelong, Michel. Pour un dialoque avec les athées. Paris: Editions du Cerf, 1965.

Lenin, V. I. Absolute and Relative Truth, or Eclecticism of Engels as Discovered by Bogdanov." In V. I. Lenin: Selected Works, ed. Marx-Engels-Lenin Institute. New York: International Publishers, 1943.

"Attitude of the Workers' Party towards Religion." In V. I. Lenin: Marx Engels Marxism, ed. Marx-Engels-Lenin Institute, 273-286. Moscow: Foreign Languages Publishing House, 1951. 
- Attitude of the Worker's Party towards Religion. In V. I. Lenin: Selected Works, ed. Marx-EngelsLenin Institute. New York: International Publishers, 1943.

- "Basic Principles." In Lenin Reader, ed. Stefan T. Possony, 1-92. Chicago: Henry Regnery Company, 1966.

- Karl Marx. In V. I. Lenin: Selected Works, ed. Marx-Engels-Lenin Institute. New York:

International Publishers, 1943.

- Materialism and Empiro-Criticism. In $\mathrm{A}$ Handbook of Marxism, 634-673. London: Victor Gollanc2, 1935.

- Materialism and Empiro-criticism. In collected Works of $V$. I. Lenin, ed. V. I. Lenin Institute, 372-381. New York: International Publishers, 1927.

- Materializm and Empiro-criticism. In $\mathrm{V}$. I. Lenin: Selected Works, ed. Marx-Engels-Lenin Institute. New York: International Publishers, 1943 .

- Philosophical Notebooks. Moscow: Progress Publishers, 1972 .

- Political Report of the central committee to the 11th Congress of the Russian communist Party. In $\underline{v}$. I. Lenin: Selected Works, ed. Marx-Engels-Lenin Institute. New York: International Publishers, 1943.

- Socialism and Religion. In V. I. Lenin: Selected Works, ed. Marx-Engels-Lenin Institute. New York: International Publishers, 1943.

- Tactics of the class struggle of the proletariat." In V. I. Lenin: Selected Works, ed. Marx-Engels-Lenin Institute. New York: International Publishers, 1943.

- The Tasks of the Youth Leaques. In $V$. I. Lenin: Selected Works, ed. Marx-Engels-Lenin Institute. New York: International Publishers, 1943. - "The Three Sources and Three Component Parts of Marxism." In V. I. Lenin: Marx, Engels, Marxism, 77-83. Moscow: Foreign Language Publishing House, 1951. 
- The Three Sources and Three component Parts of Marxism." In V. I. Lenin: Selected Works, ed. MarxEngels-LeninInstitute. New York: International Publishers, 1943.

Leo, J. "New Approach to Communism." Catholic Layman 78 (1964): 2-3.

Leonard, A. Dialoque des chrétiens et des non-chrétiens. Bruxelles: La Pensée Catholique, 1959.

Leuba, J. L. "Le dialogue entre chretiens et marxistes selon Roger Garaudy." Theologische Zeitschrift 24 $(1968)$ : 356-364.

Lewada, J. A. Die Soziale Natur der Religion. Moskau: Akademie der Wissenschaften der USSR, 1965.

Leys, Roger, and Bob Claessens. Débat: Vues chrétiennes, vues marxistes sur la liberté, fondement du bonheur. Bruxelles: Cercle d'Education Populaire, 1964.

Lieb, Fritz. Russland Unterwegs. Der Russische Mensch zwischen Christentum und Kommunismus. Bern: A. Francke Verlag, 1945.

- Wir Christen und der Kommunismus. Munich: Chr. Kaiser, 1952 .

Lilje, Hans. Atheism, Humanism and Christianity. Minneapolis: Augsburg Publishing House, 1967.

- Atheismus, Humanismus, Christentum. Der Kampf um das Menschenbild unserer zeit. Hamburg: Furche Verlag, 1965.

Lobkowicz, Nicholas. "Karl Marx's Attitude Toward Religion." The Review of Politics 26 (1964): $319-$ 352 .

- "Historical Materialism." Sacramentum Mundi (1968). 3: 426-429.

Lochman, Jan M. "Christ and/or Prometheus: Theological Issues in the Encounter Between Christians and Marxist." Journal of Ecumenical Studies 22 (1985): 440-453.

- "Christianity and Marxism: Convergence and Divergence." Christianity and Crisis: A Christian Journal of opinion 29 (1969): 131-133. 
- Church in a Marxist Society. New York: Harper and Row Publishers, 1970.

- "Evangelium fur Atheisten." Internationale

Dialog Zeitschrift 1 (1968): 221-229.

- "Gospel for Atheists." Theology Today 26 (1969): 299-311.

- "Marxist Expectations and Salvation in Christ."

The Christian Century 90 (1973): 419-423.

- "Place for Prometheus: Theological Lessons from the Christian-Marxist Dialogue." Interpretation: A Journat of Bible and Theology 32 (1978): 242-254.

Loewith, Karl. "Man's Self-alienation in the Early Writings of Marx." Social Research 21 (1954): 204-230.

Lombardo-Radice, Lucio. "Oeffnung im Marxismus." Neues Forum, April- May 1967, 329-332.

Lotz, Johann Baptist. Der Heutige Atheismus. Eine Herausforderung für das Christentum. Kevelaer: Butzon und Bercker, 1966.

Lowry, Charles w. Communism and Christ. London: Eyre and Spottiswoode, 1954 .

Lubac, Henri de. Atheisme et sens de I'homme: Une double requête de "Gaudium et Spes." Paris: Edition du Cerf, 1968 .

- Le drame de l'humanisme athée. Paris: Editions Spes, 1959.

Luik, John C. "Marxist and Wesleyan Anthropology and the Prospects for a Marxist-Wesleyan Dialogue." Wesley Theological Journal 18 (1983): 54-66.

Lukacs, György. History and Class Consciousness. Cambridge: The Mit Press, 1971.

- The Meaning of Contemporary Realism. London: Merlin Press, 1963.

Lukacs, Jozsef. "Cooperation and Dialogue." In Varieties of Christian-Marxist Dialogue, ed. Paul Mojzes, 100108. Philadelphia: Ecumenical Press, 1978 . 
- Der Junge Marx. Seine Philosophische Entwicklung von iô0-i644. Pfuilingen: veriag Günther Neske, 1965.

Lukie, Radomir. Teorija DrŽave i Prava. Belgrade: Savremena Administracija, 1964.

Lüthl, K. "Christen im Dialog mit Reformkommunisten." Reformatio 18 (1969): 359-371.

Lyon, David. "Evaluating Marxism: Some Christian Reflections." In Christianity and Marxism, ed. Alan Scarfe and Patrick Sookhdeo, 127-148. Exeter: Paternoster Press, 1982.

Machovec, Milan. A Marxist Looks at Jesus. Philadelphia: Fortress Press, 1976.

- "Atheismus und Christentum--Wechselseitige Heraus-forderung als Aufgabe." Internationale Dialog Zeitschrift 1 (1968): $38-42$.

- "Dialog als Menschlichkeit. Eine marxistische Theorie der Kommunikation I." Neus Forum, April-May $1967,321-324$.

- "Dialog in der Tschechoslowakei." Internationale Dialog Zeitschrift 1 (1968): 298-316.

- "Hindernisse des Dialogs." Neues Forum, JuneJuly 1967, 452-454.

- "Marxism and Christianity: A Marxist View." Translated by E. Adler. Student World 56 (1963): 79-83.

- Marxismus und die Dialektische Theologie. Barth, Bonhoeffer, und Hromadka in AtheistischKommunistischer Sicht. Zürich: EVZ Verlag, 1965.

Machovec, Milan, J. B. Metz, and Karl Rahner. "Kann ein Christ Marxist sein?" Neues Forum, May 1968, 293301 .

MacIntyre, Alasdair. Marxism and Christianity. New York: Schocken Books, 1968.

MacIntyre, Alasdair, and Riceur, Paul. The Religious Significance of Atheizm. New York: Columbia University Press, 1969. 
Mackinnon, D. M. , ed. Christian Faith and Communist Faith. A Series of Studies by Kembers of the Anglican Communion. London: Macmillan, 1953.

Mala Politicka Enciklopedija. Belgrade: Savremena Administracija, 1966.

Malik, C. H. "Positive Christianity and Communism." Ecumenical Review 8 (1956): 410-413.

Mandic, oleg. "Antropomorfne Religije." Mlada Pota 6 (1957) : 218-227.

- "Humanizam i Religija." In Humanizam $i$ Socijalizam: Zbornik Radova. Zagreb: Naprijed, 1963.

Marek, Franz. "Internationaler Gramsci-Kongress in Cagliari." Internationale Dialog Zeitschrift 1 $(1968)$ : $95-98$.

Marella, Paul. "Cardinal: L'Eglise et les Non-Chrétiens-Dialogue et Mission." Documentation Catholique, January $1969,76-83$.

Marinkovie, Edo. "Marksizam: Sistem ili Inspiracija." Crkva u svijetu 4 [1969]:406-411.

Markovic, Mihajlo. "Atheism Is Not Essential to Marxism: Critique of Religion Is." Journal of Ecumenical

studies 22 [1985]:529-530

- "Basic Characteristics of Marxist Humanism." Praxis International 3-4 (1969): 614-621.

"Critical Social Theory in Marx." Praxis International 3-4 (1970): 286-289.

- "Economism or the Humanization of Economics." Praxis International 3-4 (1969): 453-462.

- From Affluence to Praxis. Ann Arbor: The University of Michgan Press, 1974.

- "Humanism and Dialectic." In Socialist Humanism, ed. Erich Froom, 83-87. Garden City, New York: Doubleday Company, 1966.

- Humanizam i Dialektika. Belgrade: Prosveta, 1967 . 
"Marx and Critical Scientific Thought." Praxis International 3-4 (1968): 390-402. $17-26$.

"Marxist Humanism and Ethics." Inquiry 6 (1963):

"Marksizam, Socijalizam i Religija." Socijalizam u Svetu 8 $(1984)$ : 140-152.

"Marksizem, Človek in Kršcanska Vera: Izjava Stalnega Sveta Fran-coskega Episkopata." Bogoslovni Vestnik 37 $(1977): 332-343$.

Marsch, Wolf-Dieter. "Marxismus und Christentum--Beginn eines Dialogs?" Internationale Dialog Zeitschrift 1 (1968): 50-56.

Martelet, G. "Athèisme et communisme. Rapport de I'atheisme et du communisme. Est-ce quelque chose d'essentiel ou de purement accidentel?" Lumière et vie, July 1956, 65-104.

Martinac, B. Review of Dogma i Sloboda, by Esad ćimic. In Pogledi 16 (1986): 253-258.

Marx, Karl. "Alienated Labor." In Karl Marx: The Essential Writings, ed. Frederick L. Bender, 69-80. New York: Harper \& Row Publishers, 1972.

"Alienation and Social Classes." In The MarxEngels Reader, ed. Robert C. Tucker, 104-106. New York: W. W. Norton \& Company, 1972.

- Capital: A Critique of Political Economy. New York: Modern Library, 1906.

- Class struggle in France, 1848-1850. New York: International Publishers, 1964 .

- Contribution to the Critique of Hegel's Philosophy of Right. In The Marx Engels Reader, ed. Robert C. Tucker, 11-23. New York: W. W. Norton \& Company, 1972 .

- "Defence of the Moselle Correspondent." In Karl Marx: Selected Writings, ed. David McLellan, 24-25. oxford: Oxford University Press, 1977.

"Dialectical Materialism." In Essential Writings of Karl Marx, ed. David Caute, 41-50. New York: Macmillan Company, 1967. 
- Early Writings. New York: Vintage Books, 1975.

- Economic and Philosophic Manuscripts of 1844. In The Marx Engels Reader, ed. Robert C. Tucker, 52-

103. New York: w. W. Norton \& Company, 1972.

- The Eighteenth Brumaire of Louis Bonaparte. In Karl Marx and Frederick Engels: Selected Works, n.e., 97-168. New York: International Publishers, 1968 .

- "From the Afterword to the Second German Edition." In The Marx-Engels Reader, ed. Robert C. Tucker, 195-198. New York: W. W. Norton \& Company, 1972 .

- Grundrisse. New York: Vintage Books, 1973.

- The Holy Family. In Karl Marx: Selected Writings, ed. David McLellan, 131-155. Oxford: Oxford University Press, 1977.

- The Karl Marx Library. Edited by Saul K. Padover. vol.7, on History and People. New York: McGraw-Hill Company, 1971 .

- The Karl Marx Library. Edited by Saul K. Padover. Vol. 5, on Religion. New York: McGrawHill Book Company, 1971.

- "Letter to Annenkov." In Karl Marx: Selected Writings, ed. David McLellan, 192-194. Oxford: Oxford University Press, 1977.

. "Marx to L. Kugelmann in Hanover." In Karl Marx and Frederick Engels: Selected Works, 681 . New York: International Publishers, 1968.

- "The Materialistic Conception of History 18441847." In Karl Marx: Selected Works, ed. David McLillan, 130-215. Oxford: Oxford University Press, 1977.

- "On the Realm of Necessity and the Realm of Freedom." In The Marx-Engels Reader, ed. Robert $C$. Tucker, 318-320. New York: W. W. Norton \& Company, 1972 .

- "Preface to the Critique of Political Economy." In Karl Marx and Frederick Engels: Selected Works, 181-185. New York: International Publishers, 1968. 


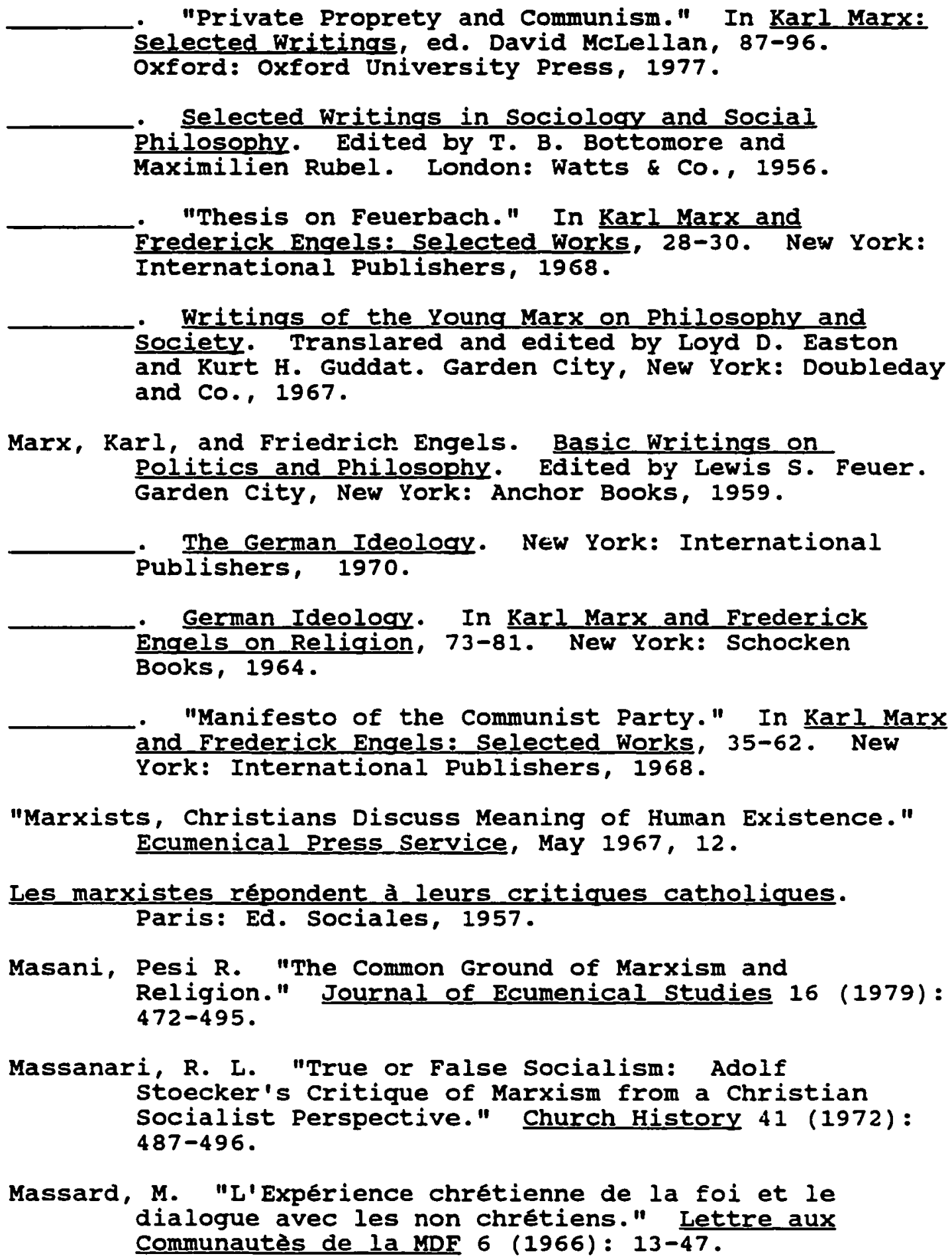


Maštruko, Ivica. Ćimic, Esad. Paper prepared for Hrvatski Biobibliografski Leksikon, 58-62. Zagreb: Jugoslovenski Leksikografski Zavod, 1990.

Matic, Marko. "Krscanstvo i Marksizam Sezdesetih Godina." obnovijeni Zivot 34 (1979): 14-35.

Mayrl, William W. "Christian-Marxist Encounter: From Dialogue to Detente" Sociological Analysis: A Journal in the Sociology of Religion 39 (1978): 8489.

McCabe, H. "Priesthood and Revolution." Commonweal, September 1968, 621-625.

McCann, Dennis. "Reinhold Niebuhr and Jacques Maritain on Marxism: A Comparison of Two Traditional Models of practical Theology." The Journal of Religion 58 (1978): 140-168.

McFadden, T. M. "Truth, Divine." Encyclopedic Dictionary of Religion. Edited by Paul Kevin Meagher, Thomas C. O'Brien, and Consuelo Maria Aherne. Washington, D.C.: Corpus Publications, 1979. O-Z:3578-3579.

McGovern, Arthur F. "Christian-Marxist Dialogue at Igls, Austria." Journal of Ecumenical Studies 24 (1987): 514-515.

- Marxism: An American Christian Perspective. Maryknoll, New York: Orbis Books, 1987.

McInnes, Neil. "Lukacs Georg." The Encyclopedia of philosophy. 1967 ed. $5: 102-104$.

. "Marxist Philosophy." The Encyclopedia of Philosophy, 1967 ed. 5:173-176. The Western Marxists. New York: Library Press, 1972 .

McLellan, David. Marxism after Marx. New York: Harper \& Row, Publishers, 1980 .

Marxism and Religion. London: Macmillan Press, 1987.

- "The Marxist Critique of Religion and the Concept of Alienation." Philosophy and Theology 1 (1987): 199-213. 
. "Response to McGovern." Journal of Ecumenical Studies 22 (1985): 534-536.

Meeres, J. R. "Marxism as a Religion. "The Expository Times 84 (1973): 214-215.

Mehl, Roger. Images de l'homme: L'homme maxxiste, I'homme existenialiste, l'homme chretien. Geneva: Labor et Fides, 1953 .

- "The Hope of the Marxist." Ecumenical Review 6 (1954): 124-128.

Metz, Johann Baptist. "The Controversy about the Future of Man: An Answer to Roger Garaudy." Journal of Ecumenical Stuaies 4 (1967): 223-234. - "Through Religion to Revolution." Dialogue 1 $(1968): 42-46$.

Metz, Johann B., Adam Schaff, and Alfonso Alvarez-Bolado. Christentum und Marxismus Heute. München: PaulusGesellschaft Selbstverlag, 1965.

Miano, Vicenzo. "Ie dialogue avec les non-croyants." Documentation Catholique, october 1968, 1665-1676.

Michalko, J. "The Church in a Socialistic Society." Dialog 2 (1963): 224-231.

Michelat, G. and M. Simon. "Catholiques déclarés et irréligieux communisants: Vision du monde et perception du champ politique." Archives de Sciences Sociales des Religions 18 (1973): 57-111.

Milić, Vojin. "Idela otudjenja i Savremena Sociologija." In Humanizam i Socijalizam, ed. Branko Bošnjak and Rudi Supek, 98-116. Zagreb: Naprijed, 1963.

Milin, Lazar. "Da li je Prirodna Nauka Bezbozna." Glasnik Srpske Pravoslavne Crkve 38 (1957): 228-232. - Naucno Opravdanje Religije. Belgrade: Prosveta, 1976.

- "Odnos Religije i Drugih Aktivnosti Coveka." Bogoslovlje 5 (1962): 52-84.

- Religija i Nauka. Belgrade: Pravoslavlje, 1969. 
- "Uticaj Pravoslavne Crkve na Duhovnu Kulturu Srpskog Naroda." Teološki Pogledi 7 (1974): 224235.

Milinkovic, Bosiljka. Bibliografija Radova o Religiji, Crkvi i Ateizmu. Zagreb: Stvarnost, 1985.

Miller, Alexander. The Christian Siqnificance of Rarl Marx. London: S.C.M., 1949 .

- Ein Christ sagt Ja zu Karl Marx. Munich: Chr. Kaiser Verlag, 1948 .

Miloševic, Nikola. "Covek Koji je Glasno Razmišljao." In Politika kao Sudbina, 217-223. Belgrade: "Srbija," 1982 .

Milosz, B. S. "A Controversial Polish Writer stanislw Brzozowski." California Slavic Studies 2 (1963): 53-95.

Milutinovic, Milan. "Marksizam i Religija." Narodna Milicija 5 (1952): 36-49.

Mlivoncic, Ivica. "Crkva i Dijalog." Naše Teme 25 (1981): 1126-1129.

Moellering, R. L. "Christianity and Communism: An Ideological Comparison." Concordia Theological Monthly 34 (1963): 645-654.

Moine, André. Après "Pacem in Terris," chrétiens et communistes. Paris: Ed. Sociales, 1965.

Moine, Nicole, and M. Sevegrand. "Marxisme et christianisme." Lettre 117 (1968): 18-26.

Moltmann, Jürgen. "The Revolution of Freedom." In openings for Marxist-Christian Dialogue, ed. T. W. Ogletree, 41-71. Nashville: Abingdon Press, 1968.

Mojzes, Paul. Christian-Marxist Dialogue in Eastern Europe. Minneapolis: Augsburg Publishing House, 1981.

- "Christian-Marxist Dialogue in Eastern Europe: 1945- 1980." Occasional Papers on Religion in Eastern Europe 4 (1984): 13-53.

- "Christian-Marxist Encounter: Is Atheism Essential to Marxism?" Journal of Ecumenical Studies $22(1985): 435-591$. 


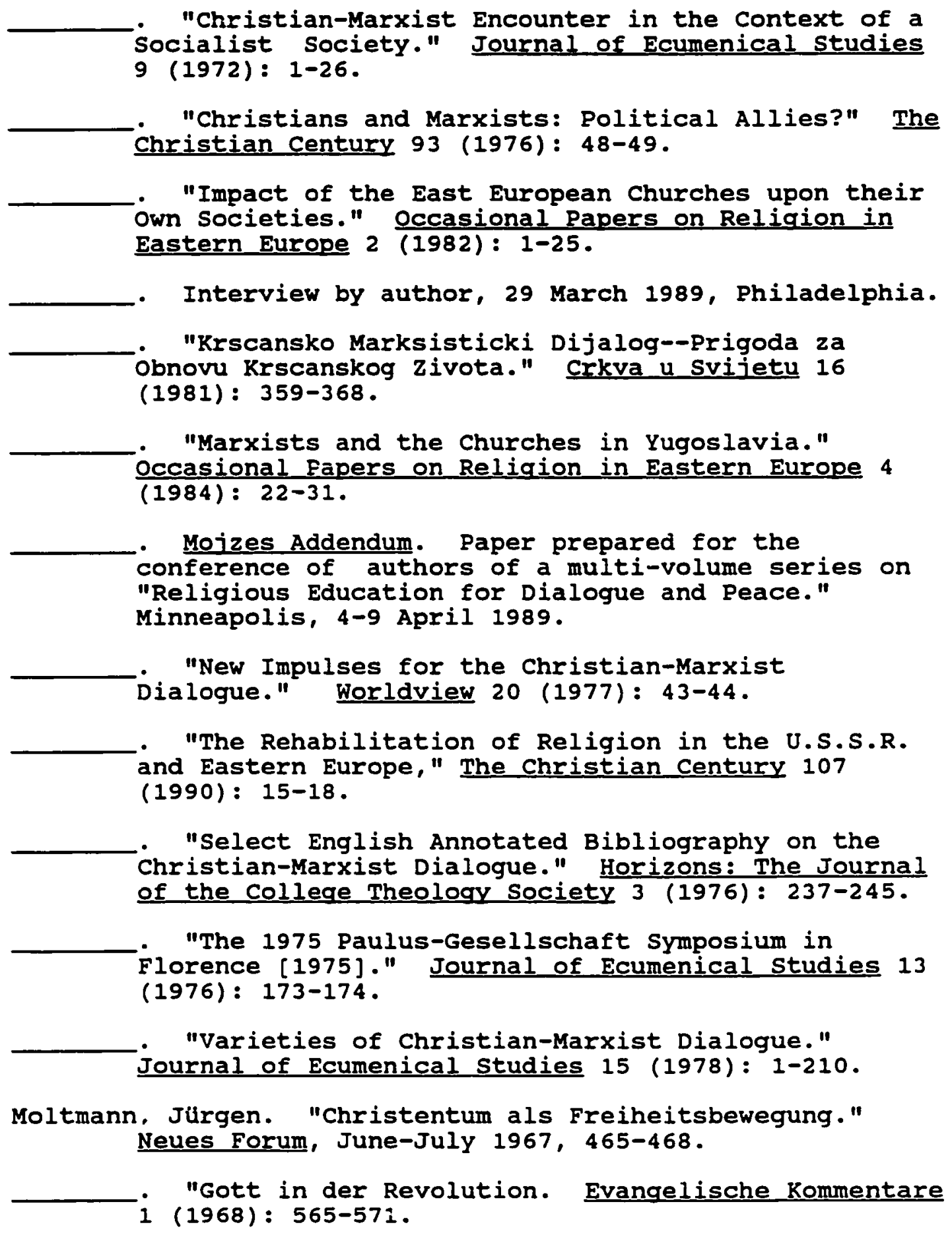


"Hcffnung ohne Glaube? Zum Eschatologischen Humanismus ohne Gott." Concilium 2 (1966): 415-421. - "Hope Without Faith: An Eschatological Humanism without God." Concilium 16 (1966): 25-40.

Religion, Revolution and the Future. New York: Charles Scribner's Sons, 1969.

- "The Christian-Marxist Dialogue in Europe." Taiwan Journal of Theology 7 (1985): 117-127.

Morale chrétienne et morale marxiste. Paris: La Palatine, 1960 .

Mudrinie, Alojz. "Dijalog Danas: Razmišljanja u Povodu Nekih Publikacija o Religiji i Marksizmu." obnovlieni Život 30 (1975): 498-506.

Munić, Fuad. Review of Čovek na Raskršcu, by Esad Ćimic. In odjek $28(1975): 22$.

- Review of Drama Ateizacije, by Esad Ćimic. In Odjek 24 (1971): 16 .

- Review of Uvod u Marxism, by Esad ćimić. In Odjek 28 (1975): 16 .

- Review of Socijalisticko Društvo i Religija, by Esad Ćimic. In Gledišta 8 (1967): 809-812.

Mury, Gilbert. "Chrètien et communistes." Cahiers du communisme, May 1964, 114-137.

Muenst, A. "Gespräch zwischen Marxisten und Christen." Civitas Monatschrift des Schweizerischen studentenvereins 20 (1965): 642-645.

- Débat chrétien-marxiste avec l'abbé Houtart. Bruxelles: Cercle d'Education Populaire, 1964 .

- "Espèrance marxiste et espèrance chrètienne." Bulletin du Centre Protestant d'Etudes, December $1967,3-27$.

- Un Marxiste peut-il comprendre Pascal? Paris: Centre d'Etudes et de Recherches Marxistes, 1962.

Myers, David. "Kolakowski, Leszek." Biogrphical Dictionary of Neo-Marxism. Edited by Robert A. Gorman. Westport, Connecticut: Greenwood Press, 1985. 232234 . 
- "Schaff, Adam." Biographical Dictionary of NeoMarxism. Edited by Robert A. Gorman. Westport, Connecticut: Greenwood Press, 1985. 377-379.

Natanson, Jacques. "La foi d'un incroyant: Chronique sur le livre de Francis Jeanson." Espirit 4 (1964): 641653.

- "Marxisme et christianisme: Un nouveau dialogue?" Esprit, December 1960, 2094-2103.

. "Marxisme et religion." Esprit, June 1961, 10891106.

Niebuhr, Reinhold. "Long Haul of Coexistence." Christianity and Crisis 19 (1959): 172-174.

- The Nature and Destiny of Man. 2 vols. New York: Charles Scribner's Sons, 1943.

Niemeyer, G. "The Ideological Motivation of Communists." Modern Age 5 (1961): 389-396.

Nineham, Dennis. "Historical Criticism." The Wesminster Dictionary of Christian Theology. Edited by Alan Richardson and John Bowden. Philadelphia: Westminster Press, 1983. 255-258

Nitsche, Roland. "Wider den Dialogismus." Neues Forum, June-July 1967 , 448-451.

Norris, Russel. God, Marx and the Future. Philadelphia: Fortress Press, 1974 .

Northrop, F. S. C. The Meeting of East and West: An Inquiry Concerning World Understanding. New York: Macmillan, 1960.

Noth, Georg. Christentum und Kommunismus in der Weltwende. Stuttgart: Evangelisches Verlagswerk, 1954 .

Novack, George. Existentialism Versus Marxism. Conflicting Views on Humanism. New York: Deli Publishing Co., 1966 .

Oestreicher, Paul. "Christians and Communists in Search of Man: Fifty Years after the Russian Revolution." Theology $70(1967)$ : 531-538.

"Dialogue Between Christianity and Marxism. From Co-existence to Pro-existence." Marxism Today, April 1967, 120-123. 
ed. The Christian Marxist Dialoque. New York: Macmillan Company, 1969.

ogletree, Thomas $W$, ed. openings for Marxist-Christian Dialoque. New York: Abingdon Press, 1969.

Ogrodzinski, Piotr. "Abramowski, Josef Edward." Biographical Dictionary of Neo-Marxism. Edited by Rebert Gorman. Westport, Connecticut: Greenwood Press, 1985. 27-28.

OpoČnsky, Milan. "Atheism: A Radical Humanism?" Journal of Ecumenical Studies 22 (1985): 516-519.

. "Christian Existence in a Communist Country." Dialog 2 (1963): 215-223.

. "Christlish-Marxistischer Dialogue in Prag." In Stimmen aus der Kirche der CSSR, ed. Be Ruys and Joseph Smolik, 129-143. Munich: Kaiser Verlag, 1968.

orsolic, Marko. "Aktualnost Marxove Kritike Religije." Encyclopaedia Moderna 7 (1972): 30-33.

- "Ia sociologie religieuse d'inspiration marxist en Yougoslavie." International Review of SocioReligious studies 22 (1973): 1 .

- Marksisticka Sociologija Religije u Jugoslaviji." Revija za Socioloaiju, no. 2 (1971): 53-59.

- "Trajna Aktualnost Marxove Kritike Religije." Kulturni Radnik 36 (1983): 124-136.

Packer, J. I. "Faith." Evangelical Dictionary of Theology. Edited Walter A. Elwell. Grand Rapids: Baker Book House, 1984. 399-402.

Page, Benjamin B. "Is Marxism Inherently Atheistic: Insights from Christian-Marxist Dialogue in Czechoslovakia." Journal of Ecumenical Studies 22 $(1985)$ : 579-589.

Parsons, Howard. Christianity in the Soviet Union. New York: AIMS, 1972 . - Humanist Philosophy in Contemporary Poland and Yugoslavia. New York: American Institute for Marxist Studies, 1966. 
Pavičevic, Vuko. "Marksizem, Ateizem in Toleranca." Teorija in Praksa 2 (1965): 1254-1257.

"Religija i Moral." Stvaranje 25 (1970): 10971109 .

- Sociologija Religije. Belgrade: Belgradeski Izdavacko-Grafizki Zavod, 1988.

Peachey, Paul. "The East-West Encounter over Human Rights: Its Religious and Social Context." Occasional Papers on Religion in Eastern Europe 5 (1985): 2528 .

Pećnik, J. Review of Uvod u Marksizam, by Esad ćimic. In Republika 31 (1975): 1020-1022.

Perchenet, Annie. "Ou en est le dialogue entre croyants et non-croyants?" Amitie, April 1969,16-29.

Pereira, Aelred J. "Catholic-Marxist Dialogue in Budapest." Tripod 43 (1988): 59-68.

Perko, Franc. "Razciscevanje Odnosov med Vernimi in Nevernimi." Znamenie 3 (1973): 2 .

Peterle, Lojze. "Pogoji za Dialog." Teorija in Praksa 20 $(1983)$ : 1030-1031.

Petrović, Gajo. "Histoire et nature." Praxis International 1-2 (1966): 73-74. - Marx in the Mid-Twentieth Century. New York: Doubleday \& Company, 1967.

Petrović, Jelena. "Marksističko Shvatanje Religije." Gradina 13 (1978): 86-101.

Pfeil, Hans. "Les fondements du dialogue." Bollettino di Informazione, January 1967, 11-19.

Philippe de la Trinité. Dialogue avec le marxisme? "Ecclesiam Suam" et Vatican II. Appendice sur Teilhard de Chardin. Paris: Ed. du Cedre, 1966.

Piediscalzi, Nicholas. "North American Christian-Marxist Dialogue." Journal of Ecumenical Studies 18 (1981): 718-719.

Piediscalzi, Nicholas, and Robert G. Thobaben, eds. From Hope to Liberation: Towards a New Christian-Marxist Dialogue. Philadelphia: Fortress Press, 1974. 
Plehanov, Georgi V. Fundamental Problems of Marxism. New York: International Publishers, 1969.

Post, Werner. "Marxism." Sacramentum Mundi. 1968 ed.

Potrc, Joze. "Marksisti i Religija." Nasa Stvarnost 15 $(1961): 666-675$.

Poujol, P. Socialistes et Chrétiens (depuis 1924). Paris: Cooperation d'Editions et de Publications, 1957.

Poulain, Jean-Claude. L'Eglise et la classe ouvrière.

Paris: Ed. Sociales, 1960.

Premec, V. "Religija i Savremeno Društvo." Kultura, nos. 13-14 (1971): 258-316.

- Review of Drama Ateizacije, by Esad ćimic. In Encyclopaedia Moderna 6 (1971): 93-94.

Price, Frank w. Marx Meets Christ. Philadelphia: Westminster Press, 1957.

Prochazka, Oldrich. "Homo Faber and Homo Sapiens." Journai of the Liberal Ministry 7 (1967): 9-19.

Prucha, Milan. "Marxism as a Philosophy of Human Existence." In The Christian-Marxist Dialogue: An International symposium, ed. Paul Oestreicher, 247266. London: Macmillan Company, 1969.

Purdy, W. "New Vatican Approach to Communism." Catholic World 197 (1963): 216-222.

Pury, Roland de. "The End and the Means [Christianity and Communism] . Union Seminary Quarterly Review 4 (1949): 19-27.

Rahner, Karl. "Einheit von Geist und Materie." Neues Forum, April-May 1967, 337-340.

- "Towards a Theology of Hope." Concurrence 1 (1969): 23-33.

- "Ueber den Dialog in der pluralistischen Gesellschaft." Schriften zur Theologie 6 (1965): 4658 .

- "Zur Theologie der Hoffnung." Internationale Dialog Zeitschrift 1 (1968): 67-78. 
371

Raines, John C., and Thomas Dean, eds. Marxism and Radical Religion: Essays Toward a Revolutionary Humanism. Philadelphia: Temple University Press, 1970 .

Rama, Carlos M. "A Marxist Looks at Christianity." CIF Reports 5 (1966): 137-144.

Rasker, A. J. "Begegnung zwischen Christentum und Kommunismusheute." Zeitschrift fur Evangelische Ethik 8 (1964): 160-174.

Rasker, Albert J., and Milan Machovec. Theologie und Revolution. Ein West-östlicher Dialog. Hamburg: Herbert Reich Verlag, 1969.

Redzic, Enver. Zasto se i Kako Marksizam Bori Protiv Religije. Sarajevo: Svjetlost, 1951.

Reid, J. P. "Marxism." Encyclopedic Dictionary of Religion. Edited by Paul Kevin Meagher. Washington, D.C.: Corpus Publications, 1979. F-N:2280-2281.

Reid, w. S. "Work." Evangelical Dictionary of Theology. Edited by walter A. Elwell. Grand Rapids: Baker Book House, 1984. 1188-1189.

Renaudin, G. Notre sens de Dieu et notre foi menacés et renouvelés par nos dialoques avec les non-chrétiens. Paris: Service Diocésain du Catéchuménat. Ronéoté, 1967.

Rich, Arthur. Marxistische und Christliche Zukunftshoffnung. Zürich: Zwingli Verlag, 1955.

Richardson, Alan. Christian Apologetics. London: S.C.M. Press, 1947.

Richmond, James. "Existentialism." The Westminster Dictionary of Christian Theology. Edited by Alan Richardson and John Bowden. Philadelphia: Westminster Press, 1983. 201-204.

- "Personalism." The Westminster Dictionary of Christian Theology. Edited by Alan Richardson and John Bowden. Philadelphia: Westminster Press, 1983. 443-444.

Riga, P. "Christianity and Atheism: A Dialogue?" World Justice, June $1967,456-478$.

Ritschl, D. "Priestly Church in Marxist Lands." Union Seminary Quarterly Review 20 (1965): 333-342. 
Robertson, Edwin. "Dialogue Between Christians and Marxists." Theology 80 (1977): 422-428.

Rogers, Edward. "Doctrine of Man, pt. 10: Marx on Man." The Expository Times 61 (1950): 205-208.

Romic, Jakov R. De Dialogo Inter Marxistas et Chritians. Vicenza, Italy: Libreria Internazionale Edizone Franciskane, 1972.

Rostenne, Paul. Ia foi des athées. Paris: Plon et Nourrit, 1953.

Roter, zdenko. "Crkva na RTV--Da ili Ne: Razmišljanje Koje Nikoga ne Obavezuje." Naše Teme 15 (1971): 15411559 .

. "Dialog med Marksisti in Kristjani." Teorija in Praksa $3(1966)$ : 713-720.

- Evolucija Cerkvenega Nauka o Socializmu, Komunizmu in Ateizmu. Ljubljana: Fakulteta za Sociologijo, Politične vede in Novinarstvo, Center a Proudavanje Religije in Cerkve, 1970.

- Karakteristicne Promjene Unutar Kršćanstva Nokon II Koncila i Odnosi Marksista i Kršcana. Zagreb: Institut za Društvena Istraživanja sveucilišta, 1970 .

- Marxism and the Religious Question. Paper presented at a conference of authors of a multivolume series on "Religious Education for Dialogue and Peace." Minneapolis, 4-9 April 1989. - "(Ne)religioznost i Društveno-Političko vladanje." Kulturni Radnik 31 (1978): 53-70. - "Politika i Religija." In Reliaija i Društvo, ed. Vjekoslav Mikecin, 102-111. Zagreb: Stvarnost, 1969 .

. "Priroda i Struktura Religioznosti u Sloveniji." Revija za Sociologiju 1 (1971): 26-39.

. "Smisao Dijaloga Izmedju Marksista i KršCana." In vierske Zajednice u Jugoslaviji, ed. Zlatko Frid, 149-156. Zagreb: Binoza, 1970.

"Socialisticna Družba in Religija." Teorija in praksa 1 (1964): 809-816. 
- Sociodemografske Znacilnosti in Druzbenopolitizno obnasanje Religiozne in Nereligiozne Populacije. Ijubljana: Fakultet za Sociologijo, Politicne Vecie in Novinarstvo, 1975.

- "Srecanje med Marksisti in Kristjani. Politizka Misao 4 (1967): 183-191.

. "Vloga Cerkve in Javno Mnenje." Teorija in

Praksa 6 (1969): 808-820.

Roter, Zdenko, and Marko Kerševan. Vera in Nevera v Sloveniji. Maribor: Obzorja, 1982.

Rowthorn, J. "Fifty Years after the Revolution: A Personal view of the Current Christian-Marxist Dialogue." Union Seminary Quarterly Review 24 (1969): 247-263.

Ruben, David-Hillel. Marxism and Materialism. Atlantic Highlands, New Jersey: Humanities Press, 1977.

Rudez, Božo. "NeobiČn Filozofsko-Teološki 'Dijalog'." Kulturni Radnik 34 (1981): 185-198.

Rumscheidt, H. Martin. "Religion as Critique: The Atheism of Gardavsky. Studies in Religion 6 (1976-77): 149157 .

Rupð̇ć, Ljudevit. "Atheismus und Religion." Königsteiner Studien 19 (1973): 150-153.

Šagi-Bunic, Tomislav. Kršćanstvo ne Može Biti Umoreno: Dvadeset i Pet Govora Održanih u Zagrebačkoj Katedrali. Split: Albert Armin, 1962 .

- "NaCela Dijaloga s Ateistima." Chap. in Ali Drugog Puta Nema. Zagreb: Kršcanska Sadašnjost, 1969 .

- Novi Ustav i Sloboda Vierolspovijesti $s$

Prilozenim Dokumentima. Zagreb: Nadbiskupski

Duhovni stol, 1973 .

. "Prilog Dijalogu o Clanstvu Vjernika u Savezu Komunista." Glas Koncila 10 (1971): 71.

- Review of Socijalisticko Društvo i Religija, by Esad ćimic. In Svesci Hrišcanska Sadašnjost 2

$(1967)$ : 93-95. 
- "Sadašnji Trenutak Dijaloga Izmedu Katolika i Komunista u Jugoslaviji." Glas koncila 11 (1972): 5 .

Samuel, Albert. Castrisme, communisme, démocratie chrétienne en Amérique Latine. Paris: Editions Gamma, 1965.

Sardelic, c. Review of Socijalisticko Društvo i Religija, by Esad ćimic. In Revija za Sociologiju 2 (1972): 103-104.

Saucy, R. I. "God, Doctrine of." Evangelical Dictionary of Theology. Edited by Walter A. Elwell. Grand Rapids: Baker Book House, 1984. 459-464

Sauter, Gerhard. "Die Frage nach der zukunft im Gespräch mit Marxisten." Concilium 5 (1969): 55-59.

Savolainen, James $W$. "A Communist Reflection of the Intellectual History of Marx as a Critique the 'Marxist-Christian' Project." Dialogue (Minnesota) 23 (1984): 281-285.

Schaff, Adam. "Marxism and the Philosophy of Man." In Socialist Humanism: An International Symposium, ed. Erich Fromm, 135-154. Garden City, New York: Doubleday and Co., 1966.

Schanz, Johannes. Katholizismus, Humanismus, Sozialismus. Recklinghausen: Paulus Verlag, 1948 .

Scheler, Hermann. Die stellung des Marxismus-Leninismus zur Religion. Berlin: Dietz-Verlag, 1958.

Schlette, H. R. Coloquium salutis--Christen und Nichtchristen Heute. Cologne: Bachem, 1965.

Schrey, Heinz-Horst. "Atheismus im Christentum? Zum Gespräch 2wischen Marxismus und Christentum." Frankfurter Hefte 24 (1969): 418-428.

Schubeck, Thomas Louis. "Liberation and Imagination: A New Theological Language in Response to the Marxist Critique of Religion." Ph. D. dissertation, University of South California, 1975.

Schulmeister, 0 . "Mit Gott und den Marxisten." Wort und Wahrheit: Monatschrift für Religion und kultur 21 (1966): 401-402. 
Selige, Martin. The Marxist Conception of Ideology. London: Cambridge University Press, 1977.

Shenk, Gerald Norman. Religion as Challenge for Humanist Science in the Work of Esad cimic and Djuro Susniic. Paper presented as part of the symposium "studies in Humanist Sciences," in Dubrovnik, Yugoslavia, April 26, 1988 .

- "The Social Role of Religion in Contemporary Yugoslavia." Ph. D. dissertation, Northwestern University, 1987.

Shepherd, Allen L. "The Christian-Marxist Dialogue in Postwar Yugoslavia." Journal of Church and State $22(1980)$ : 315-323.

Sheppard, R. "Marxian Alienation or Religious Fallenness? A Critique of the Thought of the Revolutionary Left." Theology 72 (1969): 196-202.

Sher, Gerson S. "Praxis: Marxist Criticism and Dissent in Socialist Yugoslavia." Ph. D. dissertation, Princeton University, 1975.

Shinn, R. L. "Christian-Communist Dialogue." Christianty and Crisis: A Christian Journal of opinion 26 (1967): 301-302.

Shinn, Roger, P. Lehmann, and H. Cox. "Discussion: Communist-Christian Dialogue." Union Seminary Quarterly Review 22 (1967): 213-227.

Siebert, Rudolf J. "New Marxist Conception of Christianity: Hope Versus Positivism, 2." Anglican Theological Review 59 (1977): 387-412.

Sigmond, A. R. "Die Pastoralkonstitution des Konzils als Grundlage für einen Dialog mit den Marxisten." Internationale Dialog Zeitschrift 1 (1968): 110-117.

Simundza, Drago. "Ateizam, Tendencije i 'Skrovitost' Boga u Knjizevnosti." Crkva u svijetu 13 (1978): 338-345. Covjek, Društvo, Crkva. Split: Crkva u svijetu, 1979.

Sirovec, stjepan. Ethik und Metaethik im Jugoslawischen Marxismus. Paderborn: Ferdinand Schoningh, 1982.

Skledar, Nikola. Dijalog Kršćana i Marksista. Belgrade: Mladost, 1984 . 
- Review of Politika kao Sudbina, by Esad ćimic. In Sociologija 25 (1983): 354-356.

- Review of Drama Ateizacije, by Esad Ćimie. In Filozofska Istrazivania 5 (1985): 163-165.

- "Smisao Marksistiðko-Kršcanskog Dijaloga." Kulturni Radnik 35 (1982): 138-143.

Skledar, Nikola, and Mislav Kukoc, Variation of Historical Materialism in Yugoslav sociology of Religion. Paper presented at "Postdiplomskom Studiju Humanistiðkih Znanosti u Dubrovniku," April 24, 1988 .

Skvorc, Mijo. "Geneza Velikih Ateista." Crkva u Svijetu 1 (1966): 3-20.

- "Koncil i Suvremeni Ateizam." Bogoslovska Smotra 36 (1966): 230-251.

- Vjera i Neviera: Problem Naših Dana i Misterij Nasih Dana. Zagreb: Filozofsko-Teološki Fakultet, 1982 .

- "Vjera Jednog Nevjernika." Bogoslovska Smotra 35 $(1965): 224-245$.

Solc, Joseph. "The Theology of J. L. Hromadka: A Study of Christian Doctrine in a Communist Context." Fh. D. dissertation, Southwestern Baptist Theological Seminary, 1978 .

Soubise, L. Le marxisme après Marx. Paris: AubierMontagne, 1967 .

Sövic, Arne. "Prospects for Dialogue." Ching Feng: ouarterly Notes on Christianity and Chinese Religion and culture 22 (1979): 44-49.

Spencer, Richard Leroy. "Marx, Bloch, and Moltmann. Dialectical Models of History and the Question of Ends and Means." Ph. D. dissertation, Princeton Theological Seminary, 1973.

Stanić, Janez. "O Moguénostima Dijaloga Izmedu Marksista i Kršćana." Pogledi 13 (1983): 108-111.

Stankovic, Mladen, "Covek i Religija." Praxis 7 (1970): 647-659. 
Stephan, P., and Piat, J. Socialisme et Communisme devant la Conscience chrétienne. Paris: Edition Franciscaines, 1957.

Stipieic, Ivo. "Egzistencijalno-ontološka struktura Dijaloga." Bogoslovska Smotra 37 (1967): 254-259.

Stoehr, Martin. "Christlich-Marxistische Gespräche." Evangelische Kommentare 1 (1968): 207-210.

stojanovic, svetozar. "An Ideology of Objective Meaning and Objective Responsability." In From Contact to Community: Political Theory at the Crossroads, ed. Fred R. Dallmayr, 78-116. New York: Marcel Dekker, 1978 .

- Between Ideals and Reality. Translated by Gerson S. Sher. New York: Oxford University Press, 1973.

- "Contemporary Yugoslav Philosophy." Ethics 76 (1966): 297-301.

- "The Dialectics of Alienation and the Utopia of Dealienation." Praxis International, nos. 3-4 $(1969)$ : 389-394.

- "Eticka Fenomenologija Jugoslovenskog Drustva." Filozofija 9 (1965): 45-60.

. "Etika i Interpretacija Marksa." praxis 3 $(1966): 570-578$.

- "Freedom and Democracy in Socialism." Praxis International 1 (1965): 196-206.

- "From Marxism to the Ideology of Real Socialism." Paper presented at colloquium at the Woodrow Wilson International Center for Scholars, Washington, D.C., 17 April 1986.

- In Search of Democracy in Socialism. Buffalo, New York: Prometheus Books, 1981.

756. "Ivan Vecerina: Logika." Pogledi 9 (1953): 754-

- Lawrence, Kansas, Letter to Radiša Antic, Berrien Springs, December $6,1989$.

- Marx and the Bolshevization of Marxism." Praxis International 3 (1986): 16-43. 
- Marxism and Democracy: Ruling or Dominant Class?" Praxis International 2 (1981): 28-61.

"Marxism and Socialism Now." New York Review of Books 17 (1971): 10-15.

"Moralnost Revolucionarne Avangarde kao Istoriska Predpostavka Socijalizma." praxis 3 (1966): 70-76.

- "Od Postrevolucionarne Diktature do

Socijalistiðke Demokratije." Praxis 3 (1972): 375398 .

- Perestrojka: From Marxism and Bolshevism to Gorbachev. Buffalo, New York: Prometheus Books, 1988 .

. "Revolucionarna Teologija i Etika." Filozofija 1 (1967) : 85-99.

"Sadrzina, Smisao i Smer Jednog Napada." Praxis (1973): 733-744.

- Savremena Metaetika. Belgrade: Nolit, 1964 . "Savremeni Problemi slobode Coveka." Filizofija
7 (1963): 37-43.

- "Selerova Odredba Vrednosti i Moralne Vredncsti." Jugoslovenski Casopis za Filozofiju i sociologiju 2 (1958): 17-34.

- "Socijalisticka Demokratija i SKJ." In Marks $i$ Savremenost, ed. Mihajlo Markovic, 27-35. Belgrade: Institut Društvenih Nauka, 1964.

. "Stalinist 'Partijnost' and Communist Didnity." Praxis International 10 (1974): 129-138.

Stojanovic, Svetozar, and Kurtz, Paul, eds. Tolerance and Revolution. Buffalo, New York: Prometheus Books, 1971.

Stres, Tone. "Marksistiðka Teorija Religije u Jugoslaviji JuCer i Danas." Bogoslovska Smotra 46 (1976): 255268.

Stumf, Samuel Enoch. Philosophy: History and Problems. New York: McGraw-Hill Book Company, 1983.

Suda, Max J. "Critique of Religion in Karl Marx's Capital." - Journal of Ecumenical studies 15 (1978): $15-28$. 
Supek, Rudi. "Humanizam i Naturalizam." In Humanizam $i$ Socijalizam, ed. Branko Bočnjak and Rudi Supek, 5776. Zagreb: Naprijed, 1963.

- Review of Drama Ateizacije, by Esad ćimic. In Gledišta 26 (1985): 154-155.

- Sociologila i Socijalizam. Zagreb: Znanje, 1966.

Šušnjic, Djuro. "Moદ i Nemoc Nauke u Kritici Religije."

Kultura 13-14 (1971): 55-64.

- Nauka i Religija: Funkcionalni Pristup

Religiji." Sociološki Preqled 2 (1968): 145-161.

"Nauka i Religija: Granice Nauke u Kritici

Religije." Sociološki Pregled 4 (1970): 21-33.

- Review of Drama Ateizacije, by Esad ćimic. In

Gledišta 26 (1985): 154-156.

- Ribari Ljudskih Duša. Belgrade: Mladost, 1976.

- Šanse Religijske Obnove. Zagreb: Institut za

Društvena Istraživanja sveucilišta, 1981.

- "Znati i Verovati." Gledišta 25 (1984): 119-130.

svitak, Ivan. "The Sources of Socialist Humanism." In Socialist Humanism: An International Symposium, ed. Erich Fromm, 16-28. Garden City, New York: Doubleday and Co., 1966.

Szennay, Andras. "Ueberlegungen zum ChristlichMarxistischen Dialog in Geiste des II Vaticanums." Internationale Dialog Zeitschrift 2 (1969): 79-90.

Takao, Toshikazu. "Can A Christian Be a Marxist?" The Japan Christian Quarterly 41 (1975): 38-46.

Tar, zoltan. "Lukacs, George." Biographical Dictionary of Neo Marxism. Edited by Robert Gorman. Westport, Connecticut: Greenwood Press, 1985. 266-269.

Teige, Karel. Phenomenology of Modern Art. Prague: Palan, 1966.

Thielicke, Helmut. "Can the Church and Atheism Coexist?" Theology Today 21 (1964): 108-111. 
Thobaben, Rohert. J. "Marxist-Christian Dialogue in Sweden: Rift and Reconciliation in the Encounter of 1979." Journal of Ecumenical Studies 16 (1979): 827-828.

Thompson, A. F. "A Comparison and Contrast of the Marxist Theory of the Party with the Christian Doctrine of the Church." Ph. D. dissertation, MC Gill University, 1963.

Thorez, Maurice. Pour l'union, communistes et chrétiens. Paris: Edition Sociales, 1949.

Thrower, J.A. "Marxist-Leninist 'Scientific Atheism' and the Study of Religion and Atheism in the USSR Today." Ph. D. dissertation, University of Aberdeen, 1980 .

Tobias, Robert. Communist-Christian Encounter in East Europe. Indianapolis: School of Religion Press, 1956.

Togliatti, Palmiro. "Les communistes, les catholiques, et la lutte pour la paix dans le monde." Lettre 63 $(1963): 11-17$.

Touchet, Francis H. "An Atheist Reconsiders Religion: A Review Article." Perspectives in Religious studies 6 (1979): 243-253.

Tresmontant, Claude. "Dialogue entre chretiens et marxistes au sujet de la morale." Lettre 31 (1960): 18-25.

Turner, Denys. "Alienation." Westminster Dictionary of Christian Theology. Edited by Alan Richardson and John Bowden. Philadelphia: Wesminster Press, 1983. 10-11.

- "Atheism: Is It Essential to Marxism? A Comment." Journal of Ecumenical Studies 22 (1985): 561-566.

Vancourt, R. Marxisme et pensée chrétienne. Paris: Bloud et Gay, 1948 .

Van Niekerk, Erasmus. "The Christian-Marxist Debate." Scriptura: Journal of Biblical Studies 9 (1983): 129.

Vereš, Tomo. "The Ambivalence of Marx's Atheism." Journal of Ecumenical Studies 22 (1985): 549-560. 
381

"Bit $i$ Nebit Marksistiðkog Ateizma." Marulie 12 (1979): 535-546.

- "DvoznaČnost Marxova Ateizma." Crkva u svitjetu $20(1985): 233-243$.

. "Filozofsko-Teološki Dialog s Marksom." Ph. D. dissertation, Teološki Fakultet u Zagrebu, 1970.

Vernon, Glenn. Human Interaction New York: Ronald Press Company, 1965.

- Sociology of Death. New York: Ronald Press Company, 1970 .

- Sociology of Religion. New York: McGraw-Hill Book Company, 1962 .

Verret, M. Les marxistes et la religion: Essai sur l'athéisme moderne. Paris: Edition Sociales, 1961.

Vesenjak, J. "Dialog kot Sredstvo Apostolata v Sedanjem Casu." Nova Pot 16 (1964): 533-541.

"Voraussetzungen des Atheistisch-Christlichen Dialoges." Junge Kirche 26 (1965): 561-569.

Vos, Stephane de. "Trente ans d'hisoire des relation entre les eglises chrétiennes de l'etat marxist

Yougoslave." Irénikon: Review des Moines de

Chevetogne $55(1982): 35-60$.

Vranicki, Predrag. Historija Marksizma. Zagreb: Naprijed, 1961.

"On the Concept of Practice." Praxis (1965): 4148 .

- "Socialism and the problem of Alienation." In Socialist Humanism, ed. Erich Fromm, 299-313. Garden City, New York: Doubleday \& Company, 1966. . "Teorijsko Zasnivanje Ideje o Samoupravljanju." Socijalizam 6 (1970): 727-735.

Vrcan, Srdan. "Dva Opca Pristupa Religiji: Funkcionalisticki i Marksistiðki." Zbornik Pravnog Fakulteta 31 (1981): 269-284.

. "Mladi i Sekularizacija." Pogledi 2 (1970): 177183 . 
"Neka Pitanja Sociološkog Istrazivanja Religije i Religioznosti Danas." Sociologija 11 (1969): 39-63.

"Neke Teorijske Implikacije Religioznosti kao Masovne Pojave u Socijalistiðkim Druśtvima." Revija za Sociologiju 1 (1917): 3-12.

"Nevidijiva i Nedoktrinarna Religija--Zbilja ili Čista Teorijska Konstrukcija." Nase Teme 23 (1979): 1721-1744.

- Od Krize Religije k Religiji Krize: Prilog Raspravi o Reliaiji u Uvietima suvremene Krize. Zagreb: Školska Knjiga, 1986.

- "Od Problematizacije i Kritike Religije prema Religijskoj Obnovi i Poletu." Naše Teme 24 (1980): 2173-2200.

- "Omladina, Religija i Crkva Ovdje i Sada." Socijalizam 28 (1985): 258-276.

- "Omladina i Religija." Kulturni Radnik 29 $(1976): 36-67$.

- "Premise za Raspravu o Mladima i Religiji." Pitanja 16 (1984): 5-10.

. "R-.dnicka Omladina i Religija." Pogledi 4 $(1973)$ : 125-146.

"Religioznost splitskih Srednjoškolaca i studenata." Školski Vjesnik 19 (1969): 28-52. - Review of Drama Ateizacije, by Esad Ćimić. In Gledišta 26 (1985): 127-137.

- "Sociologija Religije kao "Ancilla Theologiae"? Sociologija 20 (1978): 225-244.

Vree, Dale. "Down the Marxist Road with Harvey Cox." Christianity Today 21 (1977): 12-14.

Wackenheim, Charles. La faillite de la religion d'après Karl Marx. Paris: Presses Universitaires de France, 1963 .

Wallace, Mark I. "An Interpretation of Religion and Society in Karl Marx and Gibson Winter." Encount 47 (1986): 143-157. 
Walsh, w. H. "Metaphysics, Nature of." The Encyclopedia of Philosophy. 1967 ed. 5:300-301.

Ward, Hiley H. God and Marx Today. Philadelphia: Fortress Press, 1968 .

Weber, P. "Der Wille zum authentischen Dialog. Marxisten und Christen in Marienbad, April 1967." orientierung. Katholische Blätter für weltanschauliche Information 31 (1967): 120-122.

Weigel, G. "Communism, Religion and International Responsibility." Catholic Mind 60 (1962): 33-42.

Weingärtner, Erich, and Giovanni Barbieri, eds. Church within Socialism. Rome: IDOC, 1976.

West, Charles $c$. "Challenge from the East: Joseph Hromadka." Christianity and Crisis: A Christian Journal 13 (1953): 131-134.

- Communism and the Theologians. London: SCM Press, 1958 .

- "Atheism: Is It Essential to Marxism: A Comnent." Journal of Ecumenical Studies 22 (1985): 505-508.

. "Joseph Hromadka and the Witness of the Church in East and West Today." The Princeton Seminary

Bulletin 11 (1990): 33-45.

- "Marxists and Christians: The Fate of the Dialogue." The Journal of Religion 52 (1972): 304317 .

. "Marxist Ethics." The Westminster Dictionary of Christian Ethics. Edited by James F. Childress and John Macquarrie. Philadelphia: Westminster Press, 1986. 368-372.

. "Mission Eastern Europe: Toward a New Agenda." The Christian Century 89 (1972): 13-15.

Wetter, Gustav. "Dialectical Materialism." Sacramentum Mundi. Eàited by Karl kănner. ivew York: Herder and Herder, 1968. 3: 423-426.

. "Die Marxistische Religionsphilosophie auf dem XV. Weltkongress der Philosophie." Gregorianum 55 (1974): 151-160. 
- Die Sowjetische Konzeption der Koexistenz. Bonn: Bundeszentrale für Heimatdienst, 1959.

- "Marxism." Sacramentum Mundi 3 (1968):426.

- "Technologists and Revolutionaries." Background Information, May $1967,2-17$.

Widmer, G. Ph. L'Evangile et l'Athée. Geneva: Labor et Fides, 1965.

wiesmer, w. "Dialektischer Materialismus und Christlicher Glaube." Theologische Zeitschrift, January-February $1961,40-63$.

Wildermuth, Armin. "Marx, Religion und Christentum." orientierung. Katholische Blätter für Weltanschauliche Information 29 (1965): 66-70.

Wilkens, Erwin. "Christliches Leben im Atheistischen staat." Christ und Welt, January 1964, 20.

Will, James E. "Christian Marxist Ethical Dialogue from a Process Perspective." Encounter 42 (1981): 353-367. - "From Rejection to Employment: The Christian Use of Marxist Analysis." Explorer: A Journal of Theology 2 (1976): 40-46.

williams, Samuel w. "Communism: A Christian Critique." The Journal of Religious Thought 6 (1949): 120-135

Willoughby, W. G. "Brethren and the World of Communism." Brethren Life and Thought 10 (1965): 13-21.

Wilson, Dwight Julian. "Armagedon Now! The Premillenarian Response to Russia and Israel since 1917." Ph. D. dissertation, University of California at Santa Cruz, 1975.

Winling, Raymond. "Le christianism primitif comme 'paradigme': Evolution d'une problematique (d'Engels à Garaudy) [ 3 pts]." Review des Sciences Religieuse 55 (1981): 96-107, 198-205, 264-271.

Wirtz, Hans. "Marxisten und Christen. Vom Dialog über die Toleranz zur Zusammenarbeit." Marxistische Blätter $5(1967): 6-21$.

White, Ellen G. Patriarchs and Prophets. Mountain View, California: Pacific Press Publishing Association, 1913. 
White, Hayden V. "Feuerbach, Ludwig Andreas." The Encyclopedia of Philosophy. 1967 ed. $3: \frac{19}{190-192}$

Wood, Herbert G. "The Marxist Interpretation of History: Is It Science?" The Expository Times 64 (1952): 3640 .

Wuensch, Georg. Zwischen alle Fronten. Der Marxismus in Soziologischer und Christlicher Kritik. Hamburg: Bergstedt, Herbert Keich, 1962.

Zaehner, R. "Christianity and Marxism. Jubilee 11 (1963): 8-13.

zakarije, K. Review of Dogma i sloboda, by Esad ćimić. In Filozofska Istrazivanja 6 (1986): 595-597.

Zlobec, J. L. "Usoda Pozameznikak ki Nas Obvezuje." Sodobnost 31 (1983): 842-849. 